\title{
O CONCEITO DE EFICIÊNCIA NA REFORMA \\ SETORIAL DO ESTADO BRASILEIRO NOS ANOS 90: \\ DIFUSÃO E APREENSÃO EM UM HOSPITAL \\ PÚBLICO
}

MARIANGELA LEAL CHERCHIGLIA

Tese de Doutorado apresentada na área de concentração de Serviços de Saúde Pública da Faculdade de Saúde Pública da Universidade de São Paulo para a obtenção de Grau de Doutor.

Área de concentração: Serviços de Saúde Pública

ORIENTADORA: PROFa TITULAR SUELI GANDOLFI DALLARI

SÃo PAULO

2002

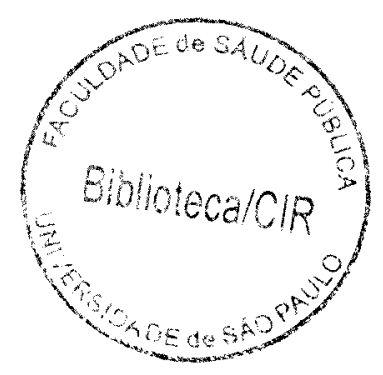


Autorizo, exclusivamente para fins acadêmicos e científicos, a reprodução total ou parcial desta tese, por processos fotocopiadores

Assinatura:

Data: São Paulo, 09 de agosto de 2002

$$
42537 / 2002 d 0
$$


À minha familia pela generosidade no amor. 


\section{AGRADECIMENTOS}

Ao meu pai cuja saudade é aliviada pela lembrança de seu violão, discos de vinil, café forte e pescarias na beira do Rio Grande e à minha mãe pela presença sempre amiga repleta de biscoitinhos, goiabadas, queijos canastra e doces de abóbora, apesar dos quilômetros de distância;

À Patrícia pela luminosidade;

O meu carinho a Antonio Carlos, Bia, Adriano e Letícia, Chico e Ivana, Rosangela, Maria do Carmo, Edson e pimpolhos, Fernando e Pedro;

Ao meu querido irmão Luiz pela paciência na correção da tese e pelas sugestões, sempre bem vindas;

À amiga Lais Silva Cisalpino pela excelência do trabalho de sistematização e coleta de dados, mas principalmente pela inestimável companhia nos momentos mais solitários da tese;

À minha orientadora, professora Sueli Gandolfi Dallari pelo acolhimento, incentivo e confiança;

Ao querido amigo paulistano Carlos Taborda que com sua generosidade conseguiu me dar um "verdadeiro lar" na paulicéia desvairada, minimizando o banzo;

Ao amigo mineiro mais paulistano que já vi, José Roberto Rodrigues Carvalho pela amizade;

À Regina pela alegria de sua presença;

Às tias Zié, Dalva e madrinha Sá Maria pelas rezas e preocupações constantes e às tias Emilia e Belinha e madrinha Eta: mulheres "que deram batalha";

Aos meus amigos do Núcleo em Saúde Coletiva (NESCON), em especial o seu coordenador Francisco Campos, pela infra-estrutura de ponta, assim como pelos momentos gastronômicos agradáveis (e engordativos) que já vivi na Faculdade de Medicina; 
Aos amigos, também, nesconianos Suzana, Luiz, Eunice, Érica, Demétrio, Márcia, Mariana, Alexandra e Otávio e a saudosa Maria de Lourdes;

A Eli lola Gurgel Andrade pela leitura cuidadosa da tese: "um ato individual, tramado coletivamente";

Aos meus colegas, professores e funcionários do Departamento de Medicina Preventiva, especialmente as professoras Soraya de Almeida Belisário e Veneza Berenice de Oliveira companheiras de PSP;

Ao Sábado Girardi que nas conversas jogadas fora ou no "papo cabeça" é sempre um delicioso aprendizado;

A José Paranaguá de Santana, Pedro Brito e Félix Rigoli pelo incentivo "recursohumanista";

À direção e às chefias do Hospital das Clínicas da UFMG pelo empenho no sentido de viabilizar cada etapa do trabalho e a seus trabalhadores pela colaboração voluntária, pela experiência enriquecedora e, muitas vezes, emocionante;

Ao Rodney Lincoln de Matos pela dedicação na coleta dos dados;

À Eliane Fernandes Araújo pela alegria e boa vontade que sempre encontrei ao chegar no porão (CEPEDISA). À Lívia Pedallini e Marilia Torres pela amizade e conversas jogadas fora, no mesmo porão;

Ao apoio financeiro da Organização Panamericana de Saúde (OPAS) e da Coordenação de Aperfeiçoamento de Pessoal de Ensino Superior (CAPES). 


\section{RESUMO}

Cherchiglia ML. O conceito de eficiência na reforma setorial do Estado brasileiro nos anos 90: difusão e apreensão em um hospital público. São Paulo; 2002. [Tese de Doutorado - Faculdade de Saúde Pública da USP]

A construção da capacidade de Estado, nos anos 90, assentada principalmente no conceito de eficiência, é assumida como objetivo central da Reforma do Estado brasileiro e de seu aparelho. O objetivo deste estudo é conhecer como o conceito de eficiência é concebido e difundido no ideário e na proposta da Reforma Setorial do Estado e como as instituições públicas de saúde e, seus trabalhadores, o percebem, incorporam, resistem ou o redefinem. Foi feita uma análise, através de categorias significativas, dos documentos de divulgação produzidos pelo Ministério da Administração e Reforma do Estado. Realizamos, também, um estudo de caso no Hospital das Clinicas da Universidade Federal de Minas Gerais (UFMG), analisandose como o conceito de eficiência se manifesta: nos vários tipos de textos produzidos na instituição em estudo; no comportamento de indicadores selecionados de produção e produtividade entre 1994/2000; no discurso dos trabalhadores (percebem e redefinem o conceito de eficiência); ressaltando quais os mecanismos de resistência adotados. Para essas análises utilizamos entrevistas semi-estruturadas com o corpo diretivo e grupos focais com os trabalhadores. Pudemos constatar que o conceito de eficiência, nas várias nuanças que revestem sua raiz econômica, foi, não apenas apreendido, incorporado e traduzido, mas tem sido mesmo implementado através de mudanças organizacionais e culturais no cotidiano do Hospital das Clínicas/UFMG.

Descritores: Eficiência, Reforma do Estado, Hospital Universitário

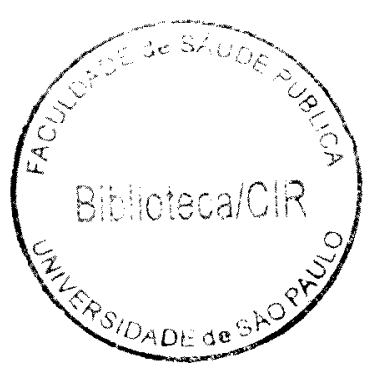




\section{SUMMARY}

Cherchiglia ML. The concept of efficiency in the sectoral reform of the Brazilian State at the 90's: diffusion and apprehension by a public hospital. São Paulo; 2002. [PhD Thesis - Faculdade de Saúde Pública da Universidade de São Paulo, Brazil]

Construction of the capacity of the State, in the 90's, a central objective of the reform of the Brazilian State and of its apparatus, was mainly defined by the concept of efficiency. The objective of this study was to know how the concept of efficiency was conceived and disseminated by the proposal of Sectoral Reform of the State and how public health institutions and their workers perceived, incorporated, resisted to it or redefined the concept. Diffusion documents produced by the Ministry of the Management and Reform of the State were analyzed on the basis of significant categories. A case study was carried out with in the Federal University of Minas Gerais Hospital (HC/UFMG), in order to better understand how the concept of efficiency was manifested in the official HC/UFMG documentation; the behavior of selected indicators of production and productivity, from 1994 to 2000; to understand how the workers perceived and defined the concept of efficiency, and if resistance mechanisms were adopted. For the analysis, half-structuralized interviews with the directive body and focal groups with the workers have been performed. We demonstrated that the concept of efficiency, and several variants which cover its economic root, were not only apprehended, incorporated and translated, but also have been implemented through organizational and cultural changes in the daily activities of the HC/UFMG.

Descriptors: Efficiency, State Reform, University Hospital, and Teaching Hospital. 
INDICE

LISTA DE ABREVIATURAS

LISTA DE TABELAS 3

LISTA DE FIGURAS

1. INTRODUÇÃO 6

2. MARCO TEÓRICO 10

2.1 O Contexto da Reforma do Estado Brasileiro nos anos 90

2.2 A Reforma do Estado Brasileiro: Governança e Eficiência 17

2.3 A Normatização da Eficiência 28

2.3 O Setor Saúde nos Cenários da Reforma do Estado 40

3. OBJETIVOS 48

3.1 Objetivo Geral $\quad 48$

3.2 Objetivos Especificos $\quad 48$

4. PROCEDIMENTOS METODOLÓGICOS 49

4.1 Desenho do Estudo 49

4.1.1 O Discurso da Eficiência na Proposta de Reforma do
Estado

4.1.2 Percepção, Incorporação, Resistência e Redefinição do 52

Conceito de Eficiência pelos Trabalhadores e Gerência

4.2 Universo de Estudo, Grupos e Pessoas Observadas 54

4.3 Técnica de Observação dos Indicadores - Coleta de 56

Dados

4.3.2 Levantamento Documental 57

4.3.3 Indicadores de Produção 58

4.3.4 Indicadores de Percepção $\quad 59$

4.4 Procedimentos para a Garantia dos Aspectos Éticos 61

4.5 Modelo de Análise 62

5. RESULTADOS 63

5.1 O Conceito de Eficiência na Reforma do Estado 63

5.1.1 Análise das Categorias Significativas nos Documentos

5.1.2 O Conceito de Eficiência nos Documentos Elaborados 68 pelo MARE 
5.2 Hospital das Clínicas da UFMG: Mudanças

Organizacionais e Gerenciais para a eficiência

5.2.1 Análise das Categorias Significativas dos Seminários e Planos Diretores do HC/UFMG de 1992 a 2000

5.2.2 Análise das Atas do Conselho Administrativo do HC/UFMG

5.2.3 O Conceito de Eficiência nos Documentos do HC/UFMG de 1992 a 2000.

5.3 Eficiência e Produção de Serviços

5.4 Percepção, Incorporação, Resistência e Redefinição do Conceito de Eficiência pelos Trabalhadores e Gerência

5.4.1 Percepção, Incorporação, Resistência e Redefinição do Conceito de Eficiência pelos Trabalhadores

5.4.2 Percepção, Incorporação, Resistência e Redefinição do Conceito de Eficiência pela Gerência Intermediária

5.4.1 Percepção, Incorporação, Resistência e Redefinição do Conceito de Eficiência pelos Diretores e Ex-Diretores

6. DISCUSSÃO

6.1 A Reforma do Estado Brasileiro (e setorial): entre o necessário e o possivel

202

6.2 O Conceito de Eficiência na Reforma do Estado 215

6.3 Hospital das Clínicas da UFMG: Mudanças

Organizacionais e Gerenciais para a eficiência

6.4 Eficiência e Produção de Serviços

6.5 Percepção, Incorporação, Resistência e Redefinição do Conceito de Eficiência pelos Trabalhadores e Gerência

7. CONSIDERAÇÓES FINAIS

8. REFERENCIAS

\section{ANEXOS}

Anexo 1 - Roteiro de Entrevistas com o Corpo Diretivo

Anexo 2 - Roteiro dos Grupos Focais

Anexo 3 - Termo de Consentimento Livre e Esclarecido

Anexo 4 - Sintese das Atas do Conselho Administrativo do Hospital das Clínicas/UFMG 


\section{LISTA DE ABREVIATURAS}

AlH

APAC

BIRD

CAPES

CLT

DATASUS

FIDEPS

FM

FUMP

FUNDEP

$\mathrm{HC}$

HC-COOP

IBGE

INAMPS

IPCA

MARE

MEC

MPAS

MS

MULTICOOP

OIT

OPAS

OS

PA

PLIDERH
Autorização de Internação Hospitalar

Autorização de Procedimentos de Alto Custo/Complexidade

Banco Interamericano de Desenvolvimento

Coordenação de Aperfeiçoamento de Pessoal de Nível Superior

Consolidação das Leis Trabalhistas

Sistema de Informação do SUS

Fator de Incentivo ao Desenvolvimento do Ensino e da Pesquisa em Saúde

Faculdade de Medicina

Fundação Mendes Pimentel

Fundação de Desenvolvimento da Pesquisa

Hospital das Clinicas

Cooperativa de Trabalho dos Médicos do Hospital das Clínicas da UFMG

Instituto Brasileiro de Geografia e Estatística

Instituto Nacional de Previdência Social

Indice de Preço ao Consumidor Ampliado

Ministério da Administração e Reforma do Estado

Ministério da Educação

Ministério da Previdência e Assistência Social

Ministério da Saúde

Cooperativa de Trabalho dos Profissionais de Informática e em Serviços Logísticos Ltda

Organização Internacional do Trabalho

Organização Pan-americana de Saúde

Organização Social

Pronto Atendimento

Programa de Liderança e Desenvolvimento de Recursos Humanos 


$\begin{array}{ll}\text { RH } & \text { Recursos Humanos } \\ \text { RJU } & \text { Regime Jurídico Único } \\ \text { RPA } & \text { Recibo de Pagamento Autônomo } \\ \text { SADT } & \text { Serviço de Apoio ao Diagnóstico e Terapêutica } \\ \text { SAME } & \text { Serviço de Arquivo Médico } \\ \text { SAST } & \text { Serviço de Atendimento ao Trabalhador } \\ \text { SIA } & \text { Sistema de Informação Ambulatorial } \\ \text { SMS/BH } & \text { Secretaria Municipal de Saúde de Belo Horizonte } \\ \text { SUS } & \text { Sistema Único de Saúde } \\ \text { UF } & \text { Unidade Funcional } \\ \text { UFMG } & \text { Universidade Federal de Minas Gerais } \\ \text { UNIMED/BH } & \text { Cooperativa Médica de Belo Horizonte } \\ \text { UO } & \text { Unidade Operacional } \\ \text { UTI } & \text { Unidade de Terapia Intensiva }\end{array}$




\section{LISTA DE TABELAS}

1 - Categorias significativas utilizadas na análise dos documentos

2 - Indicadores selecionados de produção e produtividade

3 - Sintese das categorias analisadas nos documentos produzidos pelo MARE, Brasil, 1995-1998

4 - Objetivos e valores da reforma do aparelho de Estado (administração pública) correlacionados ao conceito de eficiência ou a ele contrapostos (ineficiência)

5 - Sintese das categorias analisadas no relatório final do 1 Seminário do Hospital das Clínicas/UFMG, Belo Horizonte, 1992

6 - Síntese das categorias analisadas no Plano Diretor do Hospital das Clínicas/UFMG de 1994

7 - Sintese das categorias analisadas no Plano Diretor do Hospital das Clínicas/UFMG de 1995

8 - Sintese das categorias analisadas no Plano Diretor do Hospital das Clínicas/UFMG de 1996-1998

9 - Síntese das categorias analisadas no relatório final do III Seminário do Hospital das Clinicas/UFMG, Belo Horizonte, 1998

10 - Sintese das categorias analisadas no Plano Diretor do Hospital das Clínicas/UFMG de 1998-2000

11 - Sintese das categorias analisadas no Plano Diretor do Hospital das Clinicas/UFMG de 2000-2002

12 - Valores correlacionados ao conceito de eficiência nos documentos do Hospital das Clínicas/UFMG

13 - Total arrecado em Real, por fonte, Hospital das Clinicas/UFMG, 1994-2000

14 - Número e valor (total e médio) de AlH, Hospital das Clínicas/UFMG, 1994-2000

15 - Ranking dos dez principais procedimentos realizados (freqüência e valor), Hospital das Clinicas/UFMG 1994-2000 
16 - Freqüenncia e valor dos procedimentos ambulatoriais do Hospital das Clinicas/UFMG, 1994-2000

17 - Participação do Hospital das Clínicas/UFMG na freqüência e valor das $\mathrm{AlH}$ e dos procedimentos ambulatoriais realizados em Belo Horizonte, 1994-2000

18 - Número de pacientes (internados ou atendimentos externos) e valor pago por Convênios e Particular, Hospital das Clinicas/UFMG, 1996-2000

19 - Despesas totais (Real), Hospital das Clinicas/UFMG, 19942000

20 - Variação do valor (Real) das despesas, por item e total, Hospital das Clinicas/UFMG, 1994-2000, ANO BASE $1994=$ 100

21 - Arrecadação total e com a prestação de serviços, despesas, deficit ou superavit (Real), Hospital das Clínicas/UFMG, 1994-2000

22 - Percentual dos itens de despesa gastos com pessoal e material de consumo, na arrecadação total e na de prestação de serviços, Hospital das Clinicas/UFMG, 19942000

23 - Indicadores de produtividade da capacidade instalada, Hospital das Clínicas/UFMG, 1994-2000

24 - Número de recursos humanos e seus indicadores de produtividade, Hospital das Clinicas/UFMG, 1994-2000

25 - Média de Permanência por clínica e geral, Hospital das Clínicas/UFMG, 1994-2000

26 - Taxa de Ocupação por clínica e geral, Hospital das Clínicas/UFMG, 1994/2000

27 - Taxa de Infecção por clínica e geral, Hospital das Clinicas/UFMG, 1994-2000

28 - Valores correlacionados ao conceito de eficiência pelos trabalhadores do Hospital das Clínicas/UFMG

29 - Valores correlacionados ao conceito de eficiência pela gerência intermediária do Hospital das Clínicas/UFMG 
30 - Valores correlacionados ao conceito de eficiência pelos diretores e ex-diretores do Hospital das Clínicas/UFMG

31 - Valores correlacionados ao conceito de eficiência nos documentos do MARE, $\mathrm{HC}$ e pelos trabalhadores, gerência intermediária e pelos diretores e ex-diretores do Hospital das Clinicas/UFMG

32 - Assuntos discutidos e decisões tomadas pelo Conselho Administrativo do Hospital das Clinicas/UFMG em 1994

33 - Assuntos discutidos e decisões tomadas pelo Conselho Administrativo do Hospital das Clinicas/UFMG em 1995

34 - Assuntos discutidos e decisões tomadas pelo Conselho Administrativo do Hospital das Clínicas/UFMG em 1996

35 - Assuntos discutidos e decisões tomadas pelo Conselho Administrativo do Hospital das Clinicas/UFMG em 1997

36 - Assuntos discutidos e decisões tomadas pelo Conselho Administrativo do Hospital das Clínicas/UFMG em 1998

37 - Assuntos discutidos e decisões tomadas pelo Conselho Administrativo do Hospital das Clínicas/UFMG em 1999

38 - Assuntos discutidos e decisões tomadas pelo Conselho Administrativo do Hospital das Clínicas/UFMG de 2000

\section{LISTA DE FIGURAS}

1 - Organograma Geral do Hospital das Clínicas/UFMG, 1992 


\section{INTRODUÇÃO}

O cenário de transformações da relação Estado-Sociedade-Economia, impulsionado pela globalização econômica, tem demandado uma reestruturação da organização política e econômica dos países, com reflexos sobre o papel do Estado e, conseqüentemente, sobre o setor saúde (ALMEIDA 1999; COHN 1997). A redefinição do papel do Estado e a reestruturação de seu aparelho, nos anos 90 , ao romper com uma regulação assentada no compromisso de classe (fordismo), estrutura-se em fina sintonia com os principios do mercado e numa nova regulação: a eficientista.

No Brasil, a partir dos anos 90, agudiza-se a crise do Estado, identificandose uma crise fiscal crescente, a exaustão das formas protecionistas de intervenção na economia e uma administração pública considerada excessivamente burocrática e ineficiente. A construção da capacidade de Estado é assumida como objetivo central da Reforma do Aparelho de Estado brasileiro. O pressuposto é o de que os recentes governos, instituídos por procedimentos democráticos, apesar de deterem governabilidade carecem de governança, isto é, não têm como fazer cumprir seus mandatos, expressos em seus programas políticos (e de politicas), em função da inefetividade das decisões governamentais. Dentre outras razões, a não efetividade na implantação de políticas se daria por algum tipo de deficiência organizativa, sobretudo devida ao modelo burocrático de administração do aparelho do Estado. Nesse contexto, o conceito de eficiência destaca-se como chave para a nova face que o atual governo pretende imprimir ao Estado brasileiro, e ao seu Aparelho. Esse novo desenho do Estado passou 
a ser adotado como orientação para toda federação, diante da impossibilidade dos governos federal, estadual e municipal gerarem investimentos produtivos ou manterem a qualidade dos serviços públicos (COSTA e MELO 1998; UGÁ 1997; BRESSER PEREIRA 1996, 1998; DINIZ 1997 e 2000).

O setor público de saúde há cerca de dez anos, vem passando por uma radical descentralização administrativa. Essa reforma setorial, ainda que incompleta, tornou a regulação do setor saúde ainda mais complexa, pois com o estabelecimento do Sistema Único de Saúde - SUS, tal atividade passou a ser competência concorrente das três esferas de governo (BRASIL 1988). As novas formas de relacionamento entre instâncias governamentais de distintas esferas, e delas com os serviços e o desenvolvimento de novos modelos de gestão e de gerência, seguem a temática da reforma. O modelo administrativo burocrático é apontado como obstáculo à eficiência da gestão das organizações públicas na área da saúde. Apesar da eficiência ser também colocada como ponto fundamental da reforma setorial em marcha e fazer parte do discurso dos gestores de saúde, pouco se têm discutido e avaliado sobre a tradução e impacto do conceito de eficiência na vida e organização de uma instituição pública de saúde (ALMEIDA 1999; COSTA e MELO 1998; NOGUEIRA 1999; COHN 1997).

No Brasil, tanto a reforma do Estado como a do setor saúde, apesar de nuanças especificas, são perpassadas pela ótica da eficiência, seja a eficiência política, organizacional ou administrativa. Mesmo quando se 
colocam questões como a responsabilização ou participação, estas parecem estar "focadas" pelo conceito de eficiência.

As candentes discussões realizadas sobre o tema da reforma do Estado, seu contexto, convergências e divergências, suscitaram-nos algumas questões ao destacar a centralidade do conceito de eficiência tanto na reforma do Estado brasileiro como na do setor saúde:

- Como o conceito de eficiência foi concebido e difundido no ideário e na proposta da Reforma Setorial do Estado?

- Como as instituições públicas de saúde e os trabalhadores da saúde perceberam, incorporaram, resistiram e redefiniram o conceito?

No referencial teórico, no qual embasamos o nosso estudo, analisamos a reforma do Estado brasileiro nos anos 90, em face do contexto contemporâneo das políticas universais sob o impacto da globalização, considerando também não só as suas dimensões técnicas, administrativas e financeiras, mas também os seus aspectos institucionais e politicos. Destacamos a centralidade do conceito de eficiência para a obtenção da governança, fim último da reforma do Estado brasileiro. Apresentamos, na seqüência, uma série de "cenas de um sistema de saúde em processo de reforma".

Nos procedimentos metodológicos, explicitamos os dois caminhos utilizados para a abordagem do tema: perceber como o discurso da eficiência foi sendo construido e difundido implicou em desmontar esse discurso empregando-se categorias significativas. A utilização de categorias 
significativas permitiu-nos, posteriormente, confrontar o discurso da eficiência do MARE com os dados encontrados em nosso estudo de caso. Para compreender como os agentes destinatários dessa proposta perceberam, incorporaram, resistiram e redefiniram o conceito, realizamos um estudo de caso no Hospital das Clínicas da Universidade Federal de Minas Gerais, analisando como o conceito de eficiência se manifesta nos vários tipos de textos produzidos na instituição em estudo; no comportamento de indicadores selecionados de produção e produtividade entre 1994/2000, no discurso dos trabalhadores (percebem e definem o conceito de eficiência) e nos mecanismos de resistência adotados. Para essas análises utilizamos entrevistas semi-estruturadas com o corpo diretivo e grupos focais com os trabalhadores.

Os resultados mostram as diversas facetas do conceito de eficiência nos documentos do Ministério da Administração e Reforma do Estado - MARE e nos seminários e planos diretores do HC/UFMG. Analisamos os indicadores selecionados de produção e de produtividade entre 1992 a 2000. Por fim, apresentamos a análise e falas dos trabalhadores e gerência do Hospital. No capítulo de discussão, estes resultados foram analisados à luz das evidências encontradas na literatura.

Percebemos, nas considerações finais, o longo e doloroso processo de mudança organizacional e cultural vivenciado pelo Hospital das Clinicas, incorporando, resistindo e redefinindo o conceito de eficiência na busca constante por sobrevivência e legitimação. 


\section{MARCO TEÓRICO}

\subsection{O CONTEXTO DA REFORMA DO ESTADO BRASILEIRO NOS ANOS 90}

A globalização, segundo HIRSCH (1996), é hoje mais do que um conceito cientifico: é um fetiche. Isto é, a palavra é utilizada com freqüência sem ser entendida no detalhe, significando muitas vezes o oposto, porém tendo um significado em comum: descreve algo como um poder oculto que agita o mundo, que determina nossa vida e que nos domina cada vez mais. Para DINIZ (2000) valores como estatismo, nacionalismo e desenvolvimentismo tornaram-se anacrônicos, surgindo um novo simbolismo que enfatiza questões como integração externa, internacionalização, abertura econômica e primazia do mercado. BAUMAN (1999:7) afirma que "todas as palavras da moda tendem a um mesmo destino: quanto mais experiências pretendem explicar, mais opacas se tornam. Quanto mais numerosas as verdades ortodoxas que desalojam e superam, mais rápido se tornam cânones inquestionáveis." ${ }^{11}$.

Na perspectiva de SANTOS (2001), comungada por HIRSCH (1996), KURZ (1998) e BAUMAN (1999), a globalização simbolizaria o auge do processo de internacionalização do mundo capitalista, a existência de um "motor" único na história, representado pela mais-valia globalizada, com a condução do processo politico passando a ser atributo das grandes empresas, com substituição do debate político pelo discurso único da primazia do mercado,

\footnotetext{
'Segundo DINIZ (2000) alguns autores têm chamado a atenção para o surgimento, nos anos 80 e 90 de uma ideologia da globalização com alto poder de contágio, difundindo
} 
e o ensinamento e aprendizado de comportamentos dos quais estariam ausentes objetivos finalisticos e éticos.

Por sua vez DINIZ (2000) chama atenção para as posturas reducionistas que procuram explicar a complexa relação entre globalização e reforma do Estado. Segundo a autora, a globalização não seria um modelo único, automático, universal e comandado por forças inexoráveis, mas um modelo em que as variáveis exógenas são mediatizadas pelas condiçōes e características de cada pais ${ }^{2}$. Além disso, a globalização, não seria, tampouco, um processo monolítico, sujeito somente à racionalidade econômica, mas, perpassado pela lógica política. No entanto, seria preciso considerar que a reestruturação global da produção e a implementação das reformas neoliberais pró-mercado levaram a posturas de desconfiança em relação à democracia, com acentuada fragmentação da sociedade civil e enfraquecimento dos antigos componentes de identidade e organização coletivas

Como relembra KURZ (1998), é sobejamente conhecido o fato de que uma tal virada de época não abrange apenas os campos econômicos e políticos, mas todos os fenômenos da vida em sociedade, portanto, também as instituições culturais, científicas e religiosas, em resumo, toda a "Visão de Mundo". A concomitância relativa dessas mudanças básicas nas relações sociais, na cultura e nos diferentes campos da ciência não deve ser entendida como

valores e formas de pensar e condicionando as formulações de políticas públicas consistentes com essa forma de ver o mundo.

2 É importante destacar o estudo de KAUFMAN e SEGURA-UBIERGO (2001) que analisam se a integração nos mercados globais restringiu, de fato, os gastos sociais na América 
mecanismo causal, senão, antes de tudo, como relação análoga, como modificação do "espírito do tempo", que atravessa as estruturas sociais e com efeitos interativos em muitos campos. Dentro desta perspectiva, seria importante revisitar o pensamento de FOUCAULT (1993) sobre o poder. Para esse autor, não existe algo unitário e global chamado Poder, mas unicamente formas dispares, heterogêneas, em constante transformação. O poder não é objeto natural, uma coisa; é uma prática social e, como tal, constituída historicamente.

Rigorosamente falando, o poder não existe; existem sim, práticas ou relações de poder. O que significa dizer que o poder é algo que se exerce, que se efetua, que funciona. $E$ funciona como uma maquinaria, como uma máquina social que não está situada em algum lugar privilegiado ou exclusivo, mas se dissemina por toda estrutura social. Não é um objeto, uma coisa, mas uma relação. E esse caráter relacional do poder implica que as próprias lutas contra seu exercicio não possam ser feitas de fora de outro lugar, do exterior, pois nada está isento de poder. Qualquer luta é sempre resistência dentro da própria rede de poder. E como onde há poder há resistência, não existe propriamente o lugar de resistência, mas pontos móveis e transitórios que também se distribuem por toda a estrutura social.

As análises "foucaultianas" indicaram claramente que os poderes periféricos e moleculares não foram confiscados e absorvidos pelo aparelho de Estado. Não eram necessariamente criados pelo Estado, nem, se nasceram fora

Latina, e se nesse contexto, tais resultados poderiam ser influenciados por fatores institucionais e de politica interna. 
dele, foram inevitavelmente reduzidos a uma forma ou manifestação do aparelho central. Os poderes se exercem em niveis variados e em pontos diferentes da rede social e neste complexo os micro-poderes existem integrados ou não ao Estado. Portanto, as transformações ao nivel capilar, minúsculo, do poder não estão necessariamente ligadas às mudanças ocorridas no âmbito do Estado. A razão é que o aparelho de Estado é um instrumento específico de um sistema de poderes que não se encontra unicamente nele localizado, mas o ultrapassa e complementa.

Não se tratava, porém, de minimizar o papel do Estado nas relações de poder de determinada sociedade. O que Foucault pretendia era insurgir contra a idéia de que o Estado seria o órgão central e único de poder, ou de que a inegável rede de poderes das sociedades modernas seria uma extensão dos efeitos do Estado, um simples prolongamento ou difusão de seu modo de ação, o que seria destruir a especificidade dos poderes que a análise queria enfocar. Tanto que qualquer mudança da sociedade não poderá ser efetuada "se os mecanismos de poder que funcionam fora, abaixo, ao lado dos aparelhos de Estado a um nível muito mais elementar, cotidiano, não forem modificados" (FONSECA 1995:31).

Assim, a globalização ao invés de impor um Estado minimo, requereria a revitalização das estruturas estatais, de forma a maximizar sua eficiência na execução das reformas necessárias e na gestão do processo de inserção interna. Requereria ainda, uma ruptura com o estilo tecnocrático de governo responsável pelo agravamento do hiato do Estado em relação à sociedade e à representação dos interesses (DINIZ 2000:28). 
SANTOS Boaventura (1999) considera que o enfraquecimento do Estado não foi o efeito secundário ou perverso da globalização da economia. Foi um processo político muito preciso, destinado a constituir um outro Estado forte, cuja força esteja mais finamente sincronizada com as exigências do capitalismo global. ${ }^{3}$ Não se trata, pois, da crise do Estado, em geral, mas de um certo tipo de Estado, o de bem estar social. A força do Estado, que no período do reformismo constitui-se na capacidade em promover interdependências não mercantis, passou a consistir na capacidade do Estado em submeter todas as interdependências à lógica mercantil. Não se trata do regresso do princípio ao mercado, mas de uma nova articulação, mais direta e mais intima, entre o princípio do Estado e o principio do mercado.

Nos anos 90, a questão da viabilidade política - e dos elementos estratégicos para sua consecução - passam a ocupar um lugar central na discussão da reforma do Estado: seja no que diz respeito às características sistêmicas que interferem no processo de implementação de políticas - isto é, a problemática da governabilidade -, seja no que se refere aos pré-requisitos institucionais para a sua formulação e, principalmente, implementação - que diz respeito à governança (UGÁ 1997). Para esta autora, a discussão sobre os conceitos de governabilidade e governança teve como principal locus de reflexão os formuladores de politicas, mais especificamente, os organismos multilaterais de crédito. Ademais, esses conceitos dizem respeito às condições

\footnotetext{
${ }^{3}$ Segundo UGÁ (1997) e HIRSCH (1996) as tensões geradas pelo descompasso entre os custos socioeconômicos dos ajustes e os benefícios por eles propugnados, requerem um "forte grau de concentração de poder" no Executivo e uma exclusão dos setores populares na formulação e implementação de políticas. Para BAUMAN (1999) os "Quase-Estados" ou Estados fracos reduzem sua atuação ao papel de distritos policiais locais que garantem 0
} 
sistêmicas e ao modo de uso da autoridade que possibilitem e assegurem um determinado governo: o governo da implementação da reforma liberal.

A ingovernabilidade é tratada por OLSON (apud UGÁ 1997), como fruto da ação predatória de redes ligando atores empresariais, politicos e burocratas sobre o Estado, pois umas tendem a atuar exclusivamente guiadas por seus próprios interesses e outras, embora tendam a preservar 0 interesse da sociedade, acabam por reduzir o ritmo de crescimento econômico, dada a sua resistência à mudança de caráter tecnológico e alocativo. Sob diversas designações como captura do Estado ou privatização do Estado, as ações resultantes da prevalência de práticas generalizadas de rent seeking - isto é, os mecanismos para aquisição de renda extra-mercado pela ocupação de lugares na máquina pública, estariam levando às distorções e a perda de eficiência (DINIZ 1997; BRESSER PEREIRA 1997, 1998).

Governança pode ser definida como a capacidade do governo de tomar e executar decisões, garantindo seu efetivo acatamento pelos segmentos afetados, contribuindo, dessa forma, para assegurar sua continuidade no tempo, o que implica romper com o padrão tecnocrático da gestão pública (DINIZ 2000) ${ }^{4}$. Portanto, a governança implica na capacidade governamental de criar e assegurar a prevalência de regras universalistas nas transações sociais, politicas sociais e econômicas, penalizando ou desincentivando o

nivel de ordem necessário para a realização de negócios, sem serem temidos como freios efetivos à liberdade das empresas globais.

${ }^{4} \mathrm{Na}$ formulação do Banco Mundial governança é definida como "a maneira pela qual o poder é exercido na administração dos recursos econômicos e sociais tendo em vista o desenvolvimento", distinguindo ainda de governabilidade que descreve as condiçōes sistêmicas de exercicio do poder em um sistema político (WORLD BANK 1992, 1994). Esta 
comportamento rent seeking, promovendo arranjos cooperativos e reduzindo os custos das transaçōes. Implica, também, a capacidade de resistência à captura por grupos de interesse e por segmentos das elites governamentais, assim como a responsabilização dos governos por suas ações (accountability) (ALMEIDA 1999; BRESSER PEREIRA 1998, 2000; COSTA e MELO 1998; DINIZ 1997 e 2000; PRZEWORSKI 1998).

Reformar o Estado, nesse modelo consiste, segundo COSTA e MELO (1998:58), "numa tarefa de redesenho da estrutura de incentivos com que os agentes se deparam, de forma a assegurar a prevalência de padrões de cooperação e da racionalidade coletiva sobre os interesses setoriais". Esse redesenho baseia-se na análise do institucionalismo econômico (escolha racional) e alguns dos conceitos chave são centrados na concepção contratualista (relação agente e principal') e custos de transação ${ }^{6}$ (PRZEWORSKI 1996, 1998).

A partir do início da década de 90 ocorreu uma proliferação de reformas, rapidamente difundidas e implementadas em diversos paises, tendo como cardápio principal a centralização e insulamento político, descentralização de burocracias da área social, introdução de competição entre provedores de bens e serviços, delegação de funções regulatórias para agências independentes e

\footnotetext{
è a conotação dada por Bresser Pereira (1996) que utiliza o conceito de governança como a capacidade do Estado de implementar de forma eficiente politicas públicas.

${ }^{5}$ A relação entre principal e agente existe quando uma parte (o principal) contrata a outra parte (o agente), em troca de uma compensação, delegando a este atividades e decisões. (PRZEWORSKY 1996, 1998; PERROW 1992)

PERROW (1992:144) em critica à análise econômica de custos de transação, argumenta que os ganhos advindos com a redução dos custos de transação, não significam necessariamente maior eficiência, mas pode significar menor competitividade de preços, maiores incentivos governamentais e controle sobre o mercado de trabalho.
} 
estabelecimento de quadro de funcionários públicos restritos e essenciais (KAUFMAN 1999, apud PIERANTONI 2000).

\subsection{A REFORMA DO ESTADO BRASILEIRO: GOVERNANÇA E EFICIÊNCIA}

No Brasil, a redefinição do papel do Estado se colocou mais intensamente a partir da década dos noventa, estando identificada a uma dupla crise. Num primeiro momento, a crítica centrou-se no que foi denominada "crise fiscal". A causa fundamental da crise econômica brasileira seria o desequilibrio financeiro estrutural do setor público (níveis negativos de poupança pública) associado ao excessivo endividamento público (DINIZ 1997, 1998; BRESSER PEREIRA 1996, 1998; AZEVEDO e ANDRADE 1997). A outra crise seria dada pelo desenho institucional do Estado - burocrático e planejador-interventor. Localizase a origem da crise em variáveis organizacionais, caracterizadas pela desarticulação administrativa, perda da capacidade de planejamento e pela rigidez dos procedimentos e excesso de normas e regulamentações (BRESSER PEREIRA 1996, 1998). A crise do Estado brasileiro apresentar-seia como uma crise de govemança (BRESSER PEREIRA 1998). De acordo com - Plano Diretor da Reforma do Aparelho de Estado, do MARE (BRASIL 1995), torna-se um imperativo "estabelecer as condições para que o governo possa aumentar sua governança", definindo o escopo da proposiçâo da reforma ao Aparelho de Estado, focalizando-a na administração pública federal.

Este diagnóstico conduziria a cinco processos básicos de reforma do Estado brasileiro: (i) o ajustamento fiscal duradouro; (ii) reformas econômicas 
orientadas para o mercado, que acompanhadas de uma política industrial e tecnológica, garantissem a concorrência interna e criassem as condições para o enfrentamento da competição internacional; (iii) a reforma da previdência social; (iv) a inovação dos instrumentos de política social, proporcionando maior abrangência e promovendo melhor qualidade para os serviços sociais; e (v) a reforma do Aparelho do Estado, com vistas a aumentar sua governança (BRASIL 1995).

Um dos pressupostos é de que os recentes governos, instituidos por procedimentos democráticos, apesar de terem, relativamente, equacionado a questão da governabilidade, experimentam uma carência aguda de governança. A despeito de sua legitimidade, de sua extensa produção legislativa e de sua comprovada capacidade de influir sobre a agenda do legislativo e sobre o conteúdo da produção legal, o governo tem enfrentado consideráveis dificuldades em fazer cumprir seus mandatos de politicas públicas globais e setoriais (FIGUEIREDO e LIMONGI 1995; DINIZ 1997). Instala-se, dessa forma, um aparente paradoxo entre a "hiperatividade decisória" de um governo, que "decide, legisla e regula em proporções consideráveis", e a "falência executiva" traduzida por impotência de consecução de suas metas" (DINIZ 1997). Argumenta-se que, para evitar os efeitos negativos que esse contraste possa ter na governabilidade já alcançada, tornase imperativo o fortalecimento da eficácia do Estado, em termos da melhoria de sua capacidade de ação.

Para COSTA e MELO (1998:58), o discurso da governança parece propugnar de forma crescente uma espécie de permuta (trade off) entre os valores 
concorrentes, da eficiência, por um lado, e o da responsabilização por outro? Portanto, no desenho das novas formas institucionais da ação e da cooperação estatal estes dois principios deveriam estar sempre presentes. ${ }^{8}$ Reforçar a governança, significaria operar a transição desde um estilo de administração burocrática, enrijecida e controladora, para uma administração pública gerencial, empreendedora, flexivel, eficiente e voltada para a cidadania. O governo conduziu a reforma em três planos: no plano institucional, por meio da reforma constitucional e da legislação ordinária do pais; no plano da gestão, mediante a proposta da construção de um modelo gerencial de administração pública, e num terceiro, o cultural (MARINI FERREIRA 1995; DINIZ 1997, 2000; CHERCHIGLIA e DALLARI 1999; BRESSER PEREIRA 1998, 2000).

BRESSER PEREIRA (1997:43) definiu as principais caracteristicas da administração pública gerencial, que nortearam a reforma da administrativa brasileira: a) orientação da ação do Estado para o cidadão-usuário ou cidadão-cliente; b) ênfase no controle dos resultados através dos contratos de gestão (ao invés de controle dos procedimentos); c) fortalecimento e aumento da autonomia da burocracia estatal, organizada em carreiras ou "corpos" de Estado, e valorização do seu trabalho técnico e político de participar, juntamente com os politicos e a sociedade, da formulação e

\footnotetext{
GIRARDI (1998:173) tem colocado que o trade off nos processos de flexibilização dos sistemas de relação do trabalho dar-se-ia entre eficiência e participação, ao invés de uma agenda de pura des-regulamentação (como no passado recente)

${ }^{8}$ É interessante observar que BRESSER PEREIRA, no livro "Reforma do Estado para a cidadania", de 1998, afirma que a permuta (trade off) seria entre os valores de eficiência e democracia: "Eficiência administrativa e democracia como objetivos políticos maiores das sociedades contemporâneas, que o saber convencional coloca como contraditórios. Uma tese central deste livro é que a Reforma Gerencial, por meio da qual se atingirá maior eficiência do Estado, só será vitoriosa se contar com a existência de um regime democrático, e buscar fortalecer suas instituiçōes" (BRESSER PEREIRA 1998:17).
} 
gestão das politicas públicas; d) separação entre as secretarias formuladoras de politicas públicas, de caráter centralizado, e as unidades descentralizadas, executoras dessas mesmas politicas; e) distinção de dois tipos de unidades descentralizadas: as agências executivas, que realizam atividades exclusivas de Estado, por definição monopolistas, e as organizações sociais, que realizam os serviços sociais e científicos de caráter competitivo, em que o poder de Estado não está envolvido; f) transferência para o setor público não-estatal dos serviços sociais e científicos competitivos (publicização); g) adoção cumulativa, para controlar as unidades descentralizadas, dos mecanismos (1) de controle social direto, (2) de contrato de gestão em que os indicadores de desempenho sejam claramente definidos e os resultados medidos, e (3) de formação de quasemercados em que ocorre a competição administrada; h) terceirização das atividades auxiliares ou de apoio, que passam a ser licitadas competitivamente no mercado.

A proposta de administração gerencial propugnada pelo Plano Diretor estava inserida numa série de doutrinas administrativas que vinha dominando a agenda de reformas burocráticas em alguns paises do mundo desenvolvido, desde 0 início dos anos 80 , agrupadas na expressão "nova administração pública" ou simplesmente "gerencialismo"9 Combinaria as reflexões da nova economia política sobre o Estado à defesa ideológica do modelo de gestão

\footnotetext{
9 No caso da América Latina, o Centro Latino-Americano de Administração para o Desenvolvimento também vai propor "uma nova gestão pública" (gerencial) como condição essencial para a reconstrução da capacidade estatal dos paises latino-americanos. Nos dizeres do CLAD (1999:123): "eficiência, democratização do serviço público e flexibilização organizacional são ingredientes básicos para a modernização do setor público que o paradigma organizacional da administração pública não contém."
} 
característico do setor privado (BORGES 2000). Seus proponentes tendem a endeusar os grandes executivos privados e a apresentar como vilões os burocratas públicos, politicos e sindicatos. De acordo com esta perspectiva, - problema do Estado reduz-se a criar condições para que os administradores possam fazer aquilo que sabem melhor, isto é, gerir. Supõese, assim, que a existência de regras burocráticas excessivamente rígidas no setor público e a ênfase em controles de processos (em oposição a controles de resultados) acabem por impossibilitar uma gestão eficiente, como a praticada no setor privado, onde os administradores possuem muito mais autonomia para contratar e mobilizar recursos. A solução, portanto, é aumentar o poder discricionário dos administradores públicos, submetendoos, entretanto, a controles de resultados (OSBORNE e GAEBLER, 1995).

A proposta de reorganização do aparelho de Estado brasileiro (administração pública) baseou-se numa revisão de suas funções e da sua forma de organização, considerando os tipos de gestão e as formas de propriedade mais adequadas. Conforme o Plano Diretor (1995), para cada setor foram definidas as formas de propriedade: núcleo estratégico (estatal); setor de atividades exclusivas de Estado (estatal); setor de serviços nãoexclusivos ou competitivos (pública não-estatal); setor de produção de bens e serviços para o mercado (gestão privada). A cada setor corresponderia um princípio orientador e uma forma de gestão. No núcleo estratégico, o essencial é a correção das decisões tomadas; o principio administrativo fundamental é o da efetividade e a forma de gestão seria um misto de administração pública burocrática e gerencial. Nos setores das atividades 
exclusivas, de serviços competitivos ou não-exclusivos, setor de produção de bens e de serviços para o mercado (gestão privada), o importante seria a qualidade e o custo dos serviços prestados aos cidadãos. O principio correspondente é o da eficiência: portanto a administração deveria ser gerencial.

Segundo BORGES (2000) parece que o problema do Estado, nos termos da nova economia política, se resumiria à criação de formas organizacionais capazes de garantir a máxima eficiência econômica. Vislumbra-se a redução das formas tradicionais de organização burocrática do setor público a um núcleo de atividades "minimas", com a correspondente terceirização e privatização da maior parte das atividades restantes ou transferência para o denominado terceiro setor.

Para MISOCZKY (2001), na atualidade, uma das "verdades" prescritas no campo das políticas públicas tem sido a de que as burocracias públicas são incapazes de um gerenciamento eficiente. Portanto, as organizações públicas e as que executam atividades publicizadas devem adotar as formas organizacionais e modelos de gestão das organizações privadas, que teriam a eficiência comprovada pela mera capacidade de sobreviver e expandir-se em ambientes competitivos. Como observa BORGES (2000), a ideologia gerencialista caracteriza-se pela crença de que uma gestão mais eficiente é a solução adequada para uma ampla gama de doenças econômicas e sociais. O viés eficientista é criticado por KURZ (1998:26),

“(..) Nesta questão não se pode deixar ofuscar pelo conceito capitalista de "eficiência". Neste sentido só é eficiente aquilo que é satisfatório para o critério de uma racionalidade econômica. E é 
exatamente esta racionalidade estreita, tal como é inerente na socialização do mercado, que deve ser criticada a partir de seus fundamentos. Porque a totalização atual da crise falsifica de maneira dramática a imagem clássica da economia política, de que o principio do motivo abstrato do lucro leva a uma alocação otimizada dos recursos".

Ainda segundo este autor, seria necessário entender o conceito de "eficiência" de modo que esse possa abranger critérios coletivos, sociais, ecológicos e, não por último, estéticos (em vez de simplesmente exclui-los, como até hoje foi feito), portanto, a racionalidade limitadora da economia empresarial precisa ser superada.

Nesse momento seria importante fazer uma tentativa de conceituação de eficiência. Ao buscar a literatura sobre o tema percebe-se que tanto na economia, área reconhecidamente afeita ao conceito, como na saúde, área de incorporação recente, o termo parece ser utilizado dentro da mesma concepção: a relação de que a um gasto de energia, insumo ou input deve-se obter um resultado, produto ou output (ROSSETI 1997).

$\mathrm{Na}$ economia a eficiência produtiva é questão chave que diz respeito à mobilização dos fatores de produção de que todas as economias dispõem, independentemente de seus estágios de desenvolvimento e de seus padrões culturais. A razão essencial da busca por eficiência produtiva decorre de que os recursos são escassos, no sentido de que o suprimento de todos eles é finito ou limitado. Além disso, o conceito econômico de escassez tem a ver com as ilimitáveis necessidades sociais.

Neste sentido, a busca pela eficiência produtiva pressupõe, pelo menos, as seguintes condiçōes: 
a) utilização de todos os recursos disponiveis,

b) mobilização e combinação dos recursos disponiveis sob padrões ótimos de desempenho e de organização do processo produtivo, no sentido de que não se observe subaproveitamento do potencial máximo disponivel (ROSSETTI 1997).

Conceitualmente, a eficiência produtiva é alcançada quando, além de estarem plenamente empregados e não ociosos, os recursos mobilizados estão operando no limite máximo de seus potenciais. Uma vez alcançado este limite, não é possivel aumentar a produção pela utilização de recursos que tenham permanecido ociosos (posto que se encontram plenamente empregados), nem pela reorganização do modo pelo qual os recursos estão sendo utilizados (posto que o sistema está operando nos limites mais avançados da capacitação técnica conhecida) (ROSSETTI 1997).

KUTTNER (1998) descreve três diferentes conceitos de eficiência na vida econômica: a eficiência alocativa derivada das formulações de Adam Smith; a eficiência keynesiana e a adaptativa ou "Shumpeteriana". A eficiência alocativa tem dominado os estudos de mercado: com base em sinalizações de preços, os mercados direcionam os recursos para utilizações que maximizem os resultados vis-a-vis a aplicação. Os preços direcionam os recursos para os usos que maximizam a resposta, na forma de produtos ou serviços, relativamente à disponibilidade de capital e trabalho humano. A eficiência keynesiana se refere ao resultado potencial que se perde quando a economia entra em recessão, funcionando bem abaixo de seu potencial de utilização dos fatores produtivos. A eficiência adaptativa é baseada nas formulações de Shumpeter, segundo a qual o progresso técnico seria o 
motor do crescimento e a concorrência imperfeita seria o agente necessário deste progresso técnico.

Eficiência, no setor saúde, é conceituada como "a relação entre a quantidade de inputs ou recursos usados na produção de serviços de saúde (trabalho, capital ou equipamento) e na quantidade de outputs ou resultados produzidos (intermediários - números de tratamento, tempo de espera etc ou resultados finais de saúde - vidas salvas, anos ganhos, qualidade de vida ajustada por anos). Eficiência é usualmente medida por indicadores, tais como output por homem-hora ou custo por unidade de inputs" (GOLDSTEIN 1989; MCGRAW-HILL 1988; ADAY et. al 1998; PALMER e TORGERSON 1999).

$\mathrm{Na}$ avaliação de serviços de saúde verifica-se freqüentemente a superposição entre as definições de eficiência, eficácia, efetividade e, mesmo qualidade, a começar pelo Dicionário Aurélio (FERREIRA 1996), que considera os três primeiros termos como sinônimos. Eficaz é o que "produz o efeito desejado"; eficiência é a "ação, força, virtude de produzir um efeito" e efetivo é o "que se manifesta por um efeito real". No que tange à eficiência, as concordâncias são relativamente maiores, correspondendo essa noção às relações entre custos e resultados ou entre resultados $\mathrm{e}$ insumos. HOUAISS e VILLAS (2001) definem eficiência como: (i) poder, capacidade de uma causa produzir um efeito real; (ii) qualidade ou estado de ser efetivo, efetividade; (iii) virtude ou caracteristica de (uma pessoa, um mecanismo, uma técnica, um empreendimento etc) conseguir o melhor rendimento com o 
mínimo de erro ou de dispêndio de energia, tempo, dinheiro ou meios; (iv) rendimento.

Por outro lado, ADAY et. al (1998) fazem a seguinte diferenciação: (a) efetividade: são os beneficios do cuidado à saúde, medidos pela melhoria na saúde; (b) eficiência: relaciona as melhorias na saúde com os recursos requeridos para produzi-los; (c) equidade: está relacionada com as disparidades, a justiça e a efetividade dos procedimentos distribuídos. $O$ conceito de avaliação de eficiência é definido pela OMS como "a expressão da relação entre os resultados obtidos, através do programa saúde, e os esforços despendidos em termos de recursos humanos, financeiros e outros procedimentos de saúde, tecnologia e tempo" (Revista da Fundação SESP, 1982).

ADAY et. al (1998) e PALMER e TORGERSON (1999) diferenciam três formas de eficiência no setor saúde: a técnica, a produtiva e a alocativa. A eficiência técnica se refere à relação física entre recursos (capital e trabalho) e o resultado em saúde. A posição tecnicamente eficiente é alcançada quando a melhoria máxima possivel em resultado é obtida de um conjunto de recursos. PALMER e TORGERSON (1999) exemplificam através dos estudos da utilização do fármaco "alendronate" em osteoporose, que mostraram que $10 \mathrm{mg}$ diárias foram tão efetivas quanto $20 \mathrm{mg}$. Portanto, a utilização da dose menor é tecnicamente mais eficiente. A saúde é vista como resultado final e os serviços de saúde como resultado intermediário do sistema de cuidado à saúde. 
Eficiência produtiva, isto é, produzir resultados ao menor custo, diz respeito a ambos resultados final e intermediário. Relaciona como os recursos são organizados e geridos de maneira que minimizem os custos de produção, bem como se o pessoal, suprimentos e equipamento são pagos pela taxa que representam seus custos na melhor alternativa de utilização. A ineficiência ocorre quando o cuidado não é gerenciado no sentido de obter a maximização do potencial produtivo. Por exemplo, ineficiência ocorre quando médicos prestam serviços que poderiam ser providos pela enfermagem ou por outros trabalhadores de saúde menos qualificados, e quando a prática não traz vantagens de economia de escala como na produção de serviços de laboratório. Este conceito de eficiência é relevante no nivel individual do paciente e provedores, e no nível de instituições, sistema e comunidade.

O conceito de eficiência alocativa leva em conta não somente a eficiência produtiva, na qual os recursos do cuidado à saúde são usados para produzir resultados de saúde, mas também a eficiência na qual estes resultados são distribuidos entre a comunidade. Ineficiência alocativa pode ocorrer mesmo na produção eficiente de um sistema de saúde se o sistema produz muito ou pouco de alguns serviços relevantes na melhoria da saúde. Problemas de eficiência alocativa podem ocorrer na distribuição de cuidado de saúde, como por exemplo, quando recursos substanciais são alocados em tratamentos de efetividade questionável enquanto outros serviços (especialmente os de prevenção e promoção) são negligenciados. A área de politicas de saúde geralmente reflete as preocupações com a eficiência 
alocativa, pois incluem as decisões em relação a investimentos em (i) alternativas de políticas médicas ou não-médicas; (ii) cobertura de serviços preventivos; e (iii) mix ou tipos de tratamentos relacionados à melhoria da saúde. Tendo como meta a saúde da população, a eficiência alocativa relaciona-se com a busca de maximização da saúde da população com os limitados recursos que a sociedade tem disponível para este objetivo durante um dado período de tempo. Isto requer que a sociedade maximize a eficiência escolhendo o mix correto e mais valioso de serviços médicos e não médicos e produzindo-os a um custo mínimo.

\subsection{A NORMATIZAÇÃO DA EFICIÊNCIA}

O Plano Diretor da Reforma do Estado lista um rol de mudanças constitucionais e infraconstitucionais, ainda que não fossem as únicas alterações consideradas necessárias para a consecução dos objetivos de remodelar o Estado brasileiro. Entretanto, as alterações normativas parecem ser a face mais visivel destas mudanças. Algumas dessas normatizações vão se destacar como as Emendas que alteraram a Constituição de 1998 - a da "reforma administrativa" e a da previdência social - bem como as leis, decretos e medidas provisórias que regulamentaram propostas consideradas essenciais pelo Plano Diretor, como a das organizações sociais ${ }^{10}$.

A reforma do Estado brasileiro na segunda metade dos anos 90 começou pela ordem econômica. Em agosto de 1995 foram promulgadas cinco 
Emendas à Constituição: $n^{\circ} 5,6,78$ e 9 , referentes à quebra de monopólios estatais, privatização, protecionismo às empresas nacionais. Estas Emendas constitucionais situam-se na linha das mencionadas transformações econômicas implantadas, com o objetivo de diminuir as atribuições do Estado, o que, no entanto, não será objeto de nossa análise (SALLES 2000). As alterações das relações entre o Estado e seus servidores e agentes políticos (fim da obrigatoriedade do regime jurídico único, flexibilização da estabilidade dos servidores estatutários; eliminação da isonomia como direito subjetivo, teto para a remuneração-subsidio para os servidores e agentes), propugnadas pelo Plano Diretor do Estado, aconteceriam principalmente, através da reformulação do capítulo da administração pública na Constituição de 1998, e nas regulamentações necessárias.

A Emenda Constitucional $n^{\circ} 19$, promulgada em 04 de julho de 1998, vem estabelecer parte significativa da reforma administrativa prometida e propalada durante toda a primeira gestão do governo do presidente Fernando Henrique Cardoso, alterando profundamente as relações de trabalho entre o Estado e seus servidores, e com os agentes políticos. Contém 34 artigos, que modificaram setenta e sete preceitos da Constituição, aglutinadas em três segmentos: relações com os servidores públicos e agentes políticos; estrutura, competências e controles da Administração; e prestação de serviços públicos.

Uma alteração de grande relevância, para o programa politico de Reforma

10 SALLES (2000) discute a reforma administrativa e as mudanças normativas das propostas da reforma do Estado. Numa perspectiva, mais oficial, ver BRESSER PEREIRA (1998). 
do Estado foi introduzida pela norma do artigo $6^{\circ}$ da Emenda 19, ao viabilizar a flexibilização da estabilidade do servidor público. São criadas duas novas possibilidades para a demissão do servidor estável, além da falta grave: a demissão por insuficiência de desempenho e a exoneração por excesso de quadros. A demissão por insuficiência de desempenho ocorreria após procedimento de avaliação periódica. A Lei n ${ }^{\circ} 9.962$ de 22 de fevereiro de 2000 regulamenta como se dará o processo de demissão por insuficiência de desempenho, assegurando pelo menos um recurso hierárquico suspensivo. Não são explicitados, no entanto, os procedimentos e os critérios de avaliação. Outra forma de dispensa dar-se-ia devido ao excesso de quadros, pela obrigatoriedade dos governos de se adequarem ao limite de $60 \%$, para a despesa com pessoal ativo e inativo, permitidos pela Lei Complementar $n^{\circ} 96$ de 31 de maio de 1999, que revogou Lei Rita Camata (Lei Complementar 82, de 27 de março de 1995). Na exoneração por excesso de quadros é assegurada ao servidor uma indenização, correspondente a um salário por ano trabalhado. No entanto, antes da demissão de servidor estável, estão previstas as seguintes medidas: redução em pelo menos $20 \%$ das despesas com cargos em comissão e função de confiança, exoneração dos servidores não estáveis. A Lei no 9.801 de 16 de junho de 1999 define as normas para a perda de emprego público nessa condição, estabelecendo critérios gerais, por demissão por excesso de despesa e extinção de cargos.

O fim da obrigatoriedade do Regime Jurídico Único é previsto pelo artigo $3^{\circ}$ da Emenda 19 com a possibilidade de dispensa de concurso público para 
preenchimento de cargos e empregos de menor complexidade. O processo seletivo público através da CLT e o concurso para estatutário são regulamentados pela Lei $n^{\circ} 9962$ de 22 de fevereiro de 2000 , determinando que a admissão na Administração Pública Federal através da CLT, deva ser precedida de concurso público de provas, com exceção de cargos públicos comissionados e servidores regidos pela Lei $n^{\circ} 8112$ (Regime Jurídico Único). Várias portarias e instruções normativas são baixadas, com diretrizes e normas para a realização dos processos seletivos. Além disto, o estágio probatório também é alterado pela Emenda 19, passando a durar três anos, e a estabilidade só será alcançada depois de avaliação de desempenho no estágio probatório.

Para diminuir os gastos com agentes públicos, inúmeras normas foram inscritas no texto da Emenda 19 - art. $3^{\circ}$, alterando os artigos 37 e 39 - com o claro fim de limitar os ganhos, benefícios e vantagens remuneratórias destes agentes, bem como diminuir o campo para a contratação de pessoal em funções de confiança e cargos em comissão. Como exemplo, podemos citar o limite máximo remuneratório, que não pode exceder o subsidio mensal dos Ministros do Supremo Tribunal Federal, para todo ocupante de cargos, funções e empregos públicos da administração direta, autárquica, fundacional e de empresas estatais (ou empresas estatais que recebem recursos de entes políticos), incluindo proventos ou pensões, percebidos cumulativamente, ou não. Outras alterações importantes nas relações de trabalho foram a eliminação da isonomia como direito subjetivo, mantendo-a 
como princípio e a necessidade de lei especifica para aprovação de qualquer aumento de remuneração nos três Poderes.

No plano infraconstitucional, dentro ainda das mudanças das relações de trabalho, são definidas e criadas as carreiras denominadas exclusivas do Estado, cujos servidores não podem ser exonerados por excesso de quadros. Em todas as Medidas Provisórias e as Leis sobre criação de carreiras e gratificações, está determinado que as gratificações serão proporcionais ao resultado das avaliações de desempenho individual e ao cumprimento de metas institucionais. Os critérios para avaliação de desempenho e as metas constarão de ato conjunto do Ministro de Estado da Administração e Reforma do Estado com os Ministros de Estado dos órgãos supervisores das respectivas carreiras. As alterações nas normas das relações de trabalho alcançaram até mesmo a definição da jornada de trabalho do servidor público. De fato, o Decreto $n^{\circ} 1590$, de 10 de agosto de 1995, vem regulamentar não somente a jornada de trabalho, mas o controle de assiduidade e pontualidade.

No Plano Diretor da Reforma do Estado a implantação da administração gerencial no serviço público brasileiro ocorreria, também, através de novas formas organizacionais e da mudança de sua cultura. As novas organizações seriam as unidades executoras descentralizadas (as agências executivas - para a realização das atividades exclusivas de Estado - e as organizações sociais para os serviços sociais e científicos de caráter competitivo, em que o poder de Estado não está envolvido). O controle das unidades descentralizadas e a mudança cultural se dariam pelo instituto do 
contrato de gestão e pelo controle social direto. Estas alterações ocorreriam, principaimente, no nivel legislativo infraconstitucional e dentro das próprias organizações.

A Emenda 19 introduziu no artigo 37 da Constituição o parágrafo $8^{\circ}$, que menciona autonomia gerencial, orçamentária e financeira a ser ampliada com a celebração dos denominados "contratos de gestão" entre os administradores, dos órgãos e entidades da administração direta e indireta, e o poder público. Este contrato teria função de fixar metas de desempenho para o órgão ou entidade, assim como, mediante disposição legal, estabelecer controles, critérios de avaliação e remuneração do pessoal.

Dentro, ainda, desta linha gerencial, o controle social pela participação direta do cidadão na Administração Pública é insculpido no art. $3^{\circ} \S 8^{\circ}$ da Emenda Constitucional 19. Prescrevem, assim, as formas de participação do usuário na administração pública direta e indireta, regulando: as reclamações relativas à prestação dos serviços públicos; as avaliações periódicas da qualidade do serviço; o acesso dos usuários a registros administrativos e a informações sobre atos de governo; a disciplina da representação contra o exercício negligente ou abusivo de cargo, emprego ou função na administração pública.

Uma alteração relevante para o processo de gestão foi a permissão para que as empresas estatais, que exploram atividade econômica de produção ou comercialização de bens, ou de prestação de serviços, criassem suas próprias normas de licitação pública e contratos administrativos, sem se 
submeterem às normas da Lei $n^{\circ} 8.666$, devendo atenção, contudo, aos principios da administração pública (art. $1^{\circ}$ da Emenda Constitucional 19).

O Programa de Publicização é instrumentalizado pelas organizações sociais, primeiramente através da Medida Provisória $n^{\circ} 1.591$, de 9 de outubro de 1997 e posteriormente a Lei $n^{\circ} 9637$, de 15 de maio de 1998. Organização Social (OS) é a qualificação dada, pelo Estado, após a celebração de contrato de gestão, à pessoa juridica de direito privado, criada por iniciativa do particular, sem fins lucrativos, sob forma de fundação ou associação, cujo objetivo é a atuação em áreas não-exclusivas do Poder Público: ensino, pesquisa cientifica, desenvolvimento tecnológico, proteção do meio ambiente, cultura e saúde. Os objetivos das OS seriam: a) obter maior autonomia e flexibilidade dos serviços; b) centrar um maior foco no cidadãousuário e um maior controle social direto desses serviços por parte da sociedade; c) lograr, finalmente, parceria entre o Estado e a sociedade baseada em resultados. O Estado continuaria a financiar as atividades públicas, absorvidas pela organização social qualificada para tal, e esta seria responsável pelos resultados pactuados mediante contrato de gestão. Os mecanismos de funcionamento das organizações sociais, previstos na legislação, têm como fim dar maior flexibilização de gestão à prestação dos referidos serviços, porém, irão restringir a grande autonomia das entidades privadas, justamente por empregarem recursos públicos. A Lei determina que a gerência de entidade qualificada como organização social deverá ser feita com a participação de representantes do Estado e da sociedade civil. Importará ao Poder Público realizar o fomento da entidade, destinando 
recursos orçamentários, bens, cessão de servidor, com ônus para a origem. Tudo isto deverá estar regido por contrato de gestão, cujos objetivos e metas serão verificados pelo Estado e pela sociedade, por meio do Conselho de Administração. Em sintese, a estratégia de publicização visaria aumentar a eficiência e a qualidade dos serviços, atendendo melhor o cidadão-cliente a um custo menor. No nivel federal foram criadas as Organizações Sociais: Associação Brasileira de Tecnologia de Luz - ABTLuS (Laboratório Nacional de Luz Sincroton), e a Associação Comunicação Educativa Roquette Pinto ACERP (Fundação Roquette Pinto). A criação de Organizações Social não se restringiu ao Governo Federal. Alguns estados passaram a incentivar e a criar Organizações Sociais como, por exemplo, o estado do Pará, da Bahia e de São Paulo que instituíram programas de incentivo à criação de Organizações Sociais dirigidas à saúde e à cultura.

Outro instituto criado na presente Reforma do Estado foram dois tipos de agências que executariam atividades exclusivas de Estado: as agências executivas e as agências reguladoras. A diferença entre os dois tipos de agência está no fato de que, embora as duas gozem de maior autonomia administrativa, as agências reguladoras são entes públicos que executam politicas permanentes do Estado, enquanto que as executivas realizam politicas de governo. Os dirigentes das agências reguladoras são detentores de mandato e têm sua indicação aprovada pelo Congresso, o que não acontece com os dirigentes das agências executivas, que são de livre nomeação e exoneração pelo Presidente da República. Em princípio, as agências reguladoras regulam preços e serviços públicos monopolistas. Por 
sua vez. as agências executivas são uma qualificação concedida a autarquias e fundações públicas responsáveis por atividades e serviços exclusivos do Estado (arrecadação de impostos, promoção da seguridade social básica, garantia da segurança pública etc) (BRESSER PEREIA 1998). Assim, editou-se a Lei $n^{\circ} 9649$ de 27 de maio de 1998, cujo artigo 51 faculta ao Poder Executivo, por ato do Presidente da República, a qualificação de autarquias e fundações como Agências Executivas, desde que apresentem um plano estratégico de reestruturação e de desenvolvimento institucional em andamento e celebrem Contrato de Gestão com o Ministério supervisor. Os efeitos juridicos incidentes sobre as entidades qualificadas como Agências Executivas são: cumprimento de metas estabelecidas no Contrato de Gestão; aumento da autonomia administrativa e financeira; submissão ao controle de seus resultados, com responsabilização do dirigente, caso não os alcancem. Podemos citar como exemplo a Agência Nacional de Vigilância Sanitária (ANVISA) e a Agência de Saúde Suplementar (ANSS) que visam disciplinar os serviços públicos de saúde, onde particulares desempenham o exercicio da livre iniciativa.

As Agências de Regulação foram instituidas, num primeiro momento, para acompanhar o processo de privatizações, a exemplo da experiência francesa e da inglesa, visando estabelecer critérios pertinentes para a promoção da concorrência. Ademais, regulariam e controlariam as concessionárias de serviços públicos, postos em sua área de competência, em que o Estado deixou de ser executor. Relevante característica das agências reguladoras é sua maior independência em relação às demais 
autarquias (independência política dos gestores, independência técnica decisional, independência normativa e independência gerencial, orçamentária e financeira). A Agência Nacional de Energia Elétrica (ANEEL) e de Telecomunicações (ANATEL) e a Agência Nacional do Petróleo (ANP) são exemplos de agências reguladoras que têm como finalidade disciplinar as concessionárias de serviços públicos.

A reforma da previdência era considerada fundamental pelo Plano Diretor da reforma do Estado para acabar com a aposentadoria integral e com as aposentadorias precoces (que tornavam o sistema previdenciário público brasileiro um sistema de privilégios), além de reequilibrar as contas da Previdência Social. A mudança constitucional abrangeria as previdências pública e privada e abriria espaço para maior regulação daquela do setor público.

A Emenda de $n^{\circ} 20$, modificando o sistema de previdência social, veio alterar inúmeras normas dos artigos 40, 195 e 201 da Constituição, trazendo modificações no regime de aposentadoria dos agentes públicos e dos empregados da iniciativa privada, assim como alterou a relação entre a União e os Estados e Municipios. Esta Emenda causou grandes discussões nacionalmente, no que tange a possiveis inconstitucionalidades, referentes, principalmente, ao principio do federalismo e ao direito adquirido dos servidores e beneficiários. As principais alterações na aposentadoria dos servidores do setor público federal foram: mudança de enfoque do tempo de serviço para tempo de contribuição; exigência de idade mínima para a aposentadoria voluntária integral por tempo de contribuição; exigência de 
tempo mínimo de exercício no serviço público e no cargo efetivo; fim da aposentadoria especial para o professor universitário; extinção da aposentadoria proporcional por tempo de serviço; e fim da aposentadoria com tempo reduzido para magistrados, membros do Ministério Público ou de Tribunal de Contas. A regulamentação da previdência dos servidores públicos federais se deu através da Lei $n^{\circ} 9717$ de 27 de novembro de 1998 , que dispõe sobre regras gerais para a organização e o funcionamento dos regimes próprios de previdência social dos servidores públicos da União, dos Estados, do Distrito Federal e dos Municípios, dos militares dos Estados e do Distrito Federal e pela Lei $n^{\circ} 9783$ de 28 de janeiro de 1999, que trata da contribuição para o custeio da previdência social dos servidores públicos, ativos e inativos, e dos pensionistas dos Três Poderes da União. Várias Instruções normativas do Ministério da Previdência Social foram baixadas para especificar termos e orientar procedimentos das regras de transição.

Além das mudanças constitucionais e infraconstitucionais, uma série de outros projetos é considerada fundamental, no Plano Diretor da Reforma, para a implantação de uma gestão de caráter gerencial no Estado brasileiro. Enumeramos alguns projetos, como o Projeto Cidadão, com o objetivo de aperfeiçoar as relações entre os órgãos da Administração Pública e os cidadãos; Projeto de Qualidade e Participação, com o objetivo de introduzir novos conceitos e técnicas de gestão pública, baseados no desempenho, na redução ao mínimo dos erros, e na participação dos funcionários na definição dos processos de trabalho buscando uma nova política de recursos humanos com o objetivo de profissionalizar e valorizar o servidor público; 
Rede Governo, que visa o provimento de uma moderna rede de comunicação de dados interligando de forma segura e ágil a Administração Pública; Sistemas de Gestão Pública (Controle e Informações Gerenciais) com o objetivo de permitir a transparência na implementação das diversas ações do governo, possibilitando seu acompanhamento e avaliação, bem como a disponibilização das informações não privativas e não confidenciais para o governo, como um todo, e a sociedade. A maioria destes projetos está sendo implementada, alguns com maior rapidez que outros.

Por fim, editou-se a Lei Complementar $n^{\circ} 101$, de 04 de maio de 2000. A Lei de Responsabilidade Fiscal busca delimitar o campo de atuação e de responsabilidades dos gestores públicos, por meio de critérios técnicos obrigatórios a serem atendidos por todos sob pena de, caso não observados, haver responsabilização administrativa e criminal. A finalidade é claramente coibir a contínua prática de ingerência com a coisa pública, para impedir, conseqüentemente, crescimento e manutenção do déficit público e a divida pública interna.

A mencionada lei compele o administrador público ao planejamento, exigindo a programação financeira, o cronograma de execução mensal de desembolso e o cumprimento das metas estabelecidas. Prevê instrumentos de transparência da gestão fiscal, bem como exige o incentivo à participação popular e realização de audiências públicas. Os sistemas de controle serão exercidos pelos: Tribunais de Contas, Legislativos, Ministério Público e órgãos de controle interno de cada Poder, cabendo a verificação do atingimento de metas; das operações de crédito; das despesas com pessoal; 
das dividas consolidadas e mobilária; dos gastos totais; e outros.

Podemos dizer que, com exceção da Reforma Constitucional Tributária, as questões de maior relevância para o programa do governo já foram implementadas, pelo menos no aspecto normativo. De fato, ao longo dos últimos seis anos, ocorreu grande atividade legislativa de alteração das estruturas estabelecidas.

\subsection{O SETOR SAÚDE NOS CENÁRIOS DA REFORMA DO ESTADO}

Na reforma propugnada pelo MARE para o sistema de saúde brasileiro, ao mesmo tempo em que se reiteram os princípios do Sistema Único de Saúde - SUS - tem seu foco voltado para a assistência hospitalar e é explicitamente pautada no modelo inglês ${ }^{11}$ (BRASIL 1995; BRESSER PEREIRA 1998). Partindo da premissa de que a existência de recursos é sempre limitada, o objetivo da reforma, no Plano Diretor, "seria garantir um melhor atendimento ao cidadão através de um controle mais adequado do sistema, que garanta menores custos e melhor qualidade dos serviços pagos pelo Estado." Para alcançar esse grau maior de controle, a reforma optava por três estratégias: descentralização, com maior clareza na definição das atribuições e no poder

\footnotetext{
"As mudanças no sistema nacionais de saúde inglès (NHS), no final dos anos 80 , foram condicionadas pela iniciativa de criação de quase-mercado (internal market) para a provisão dos serviços de saúde. A proposta de quase-mercado compreendia: (i) separação entre provisão e financiamento de serviços - o Estado deixa de ser provedor, mas continua a financiar, coordenar e regular; (ii) separação de funções entre os niveis central e operacional, para que o executivo desenvolva sua capacidade de formulação de politica; (iii) transformação das autoridades sanitárias em compradores de atenção à saúde e ampliação das atividades dos médicos da atenção primária que se tornaram gestores de fundos públicos para a compra de serviços; (iv) incentivo à transformação dos hospitais públicos em empresas autônomas (trusts) habilitadas a competir no mercado, inclusive com os hospitais privados, pelos recursos disponiveis para o atendimento aos clientes (McKEE e HEALY 2002; DIXON e ROBISON 2002; COSTA et. al 2000; ALMEIDA 1999).
} 
de decisão das diferentes esferas de governo; montagem de um Sistema de Atendimento de Saúde em nivel municipal, estadual e nacional, constituído de dois subsistemas: Subsistema de Entrada e Controle e Subsistema de Referência Ambulatorial e Hospitalar; e montagem de um sistema de informações em saúde visando acompanhar os resultados das ações dos dois subsistemas mencionados, conectados em rede, com capacidade de controlar despesas, gerar indicadores para a vigilância epidemiológica, avaliar a qualidade e medir resultados alcançados.

Posteriormente, a proposta administrativa do setor saúde foi explicitada, e tornando-se mais parecida com as propostas de reforma inglesa: (i) descentralizar a administração e o controle dos gastos com a saúde, que seriam distribuídos aos municípios de acordo com a população existente e não com o número de leitos; (ii) criar um quase-mercado entre os hospitais e os ambulatórios especializados, que passariam a competir pelos recursos públicos administrados localmente; (iii) transformar os hospitais em organizações públicas não-estatais (organizações sociais); e (iv) criar um sistema de entrada e triagem constituido por médicos clínicos ou médicos de família que poderiam ser funcionários do Estado ou pagos por capitação (remunera-se o médico com um valor fixo por paciente inscrito ou capitado ${ }^{12}$ por um periodo determinado, independente do tipo e quantidade de serviço

\footnotetext{
${ }^{12}$ Outro conceito de capitação que não deve ser confundido com este refere-se ao sistema de pagamento a serviços de manutenção da saúde (ou seguradoras) por empresas ou organizações para atendimento de seus empregados. Neste caso a organização seguradora ou mantenedora de serviços de saúde recebe um montante mensal ou anual por pessoa, comprometendo-se com a sua atenção nas bases contratadas.
} 
prestado - número de visitas ou consultas), a exemplo dos general practioners do sistema de saúde inglês (BRESSER PEREIRA 1998).

A revisão das formas organizativas da ação (e da cooperação) estatal parece figurar no rol das referidas condições para o aumento da governança (NOGUEIRA e GIRARDI 1997). A implementação de Organizações Sociais é uma estratégia central do Plano Diretor da Reforma do Aparelho do Estado, que atingiria de forma mais explícita o setor saúde, pela transformação de hospitais públicos em Organizações Sociais (OS). No discurso oficial, os serviços não-exclusivos não possuem o poder de Estado, mas este se faz presente porque tais serviços envolvem direitos humanos fundamentais, como os da educação e da saúde, ou porque possuem "economias externas" relevantes, na medida que produzem ganhos que não podem ser apropriados pela via do mercado. São exemplos desse setor os serviços de educação, saúde, cultura e pesquisa cientifica. A propriedade ideal para este setor seria a pública não-estatal. Não é propriedade estatal, porque aí não se exerce o poder de Estado. Não é, por outro lado, propriedade privada, porque se trata de um tipo de serviço de caráter público (BRASIL 1997).

Pela proposta de Reforma do Aparelho de Estado, os objetivos das OS seriam: a) obter maior autonomia e flexibilidade dos serviços; b) centrar um maior foco no cidadão-usuário e um maior controle social direto desses serviços por parte da sociedade; c) lograr, finalmente, parceria entre o Estado e a sociedade baseada em resultados. O Estado continuaria a financiar as atividades públicas, absorvidas pela organização social qualificada para tal, e esta seria responsável pelos resultados pactuados 
mediante contrato de gestão. Em síntese, a estratégia de publicização visa a aumentar a eficiência e a qualidade dos serviços, atendendo melhor o cidadão-cliente a um custo menor (BRASIL 1997).

Segundo ALMEIDA (1999) ainda que aparentemente desconectada do processo de implantação do SUS, essa proposta vem sendo implementada de forma paulatina, mesmo que tenha sido pifia a remodelação organizativa, especialmente a transformação de hospitais públicos em organizações sociais. No âmbito federal, a criação de OS fica restrita às que já existiam os hospitais da Fundação das Pioneiras Sociais, o Hospital das Clínicas de Porto Alegre, e às recentes experiências regionais de São Paulo e Bahia (MELO e TANAKA 2001; IBAÑEZ et. al 2001).

Entretanto, se existe ambigüidade da agenda do Governo Federal para o setor saúde, este apresenta uma dinâmica própria de mudanças. Há cerca de dez anos, esse setor social vem passando por uma radical descentralização administrativa, que implica novas formas de relacionamento entre instâncias governamentais, de distintas esferas, e delas com os serviços. A reforma setorial tem trazido, ainda, mudanças nas relações sociais (politicas, econômicas e normativas) existentes entre o Estado, a população e os agentes ou atores (financiadores, produtores e provedores) da produção de serviços de saúde (QUINTANA et. al 1996). Em relação ao financiamento do sistema, a legislação que instituiu o Sistema Único de Saúde (SUS) definiu as bases do modelo, tanto com respeito às fontes quanto aos mecanismos de transferência não condicionada de recursos entre o nivel federal e os estados e municipios. Na prática, observa-se um modelo misto, com 
transferências automáticas calculadas sobre critérios pactuados, convivendo com transferências negociadas, principalmente no caso de recursos de investimento ${ }^{13}$ (CAMPOS 2001)

Ponto fulcral da reforma sanitária brasileira é o processo de descentralização envolvendo, nāo somente a transferência de serviços, mas também de responsabilidades, poder e recursos da esfera federal para a estadual e municipal. Passou-se de um sistema político, administrativo e financeiro centralizado para um cenário em que milhares de gestores passaram a constituir-se atores fundamentais no campo da saúde (LEVCOVITZ et. al 2001). As normas gerais do processo de descentralização do sistema foram expressas na forma das NOB (Norma Operacional Básica) em quatro versões: 1991, 1992, 1993 e 1996; e mais recentemente, em uma norma especifica da assistência, a NOAS $2001^{14}$. Além das NOB, uma profusão de portarias e normas técnicas emitidas pelo Ministério da Saúde procuram condicionar a ação dos estados e municipios (CAMPOS 2001; LEVCOVITZ et. al 2001). Isto implicou o desenvolvimento de novas formas de gestão governamental e de gerência organizacional, em prenúncio a uma das orientações fundamentais da atual Reforma do Estado.

\footnotetext{
13 Autores como LEVCOVITZ (1997) e MACHADO (1999) têm discutido as crises, as causa e consequèncias do desfinanciamento do setor saúde. Para estes autores, apesar de ter ocorrido um aumento progressivo do aporte financeiro dos municipios para o financiamento do sistema, este não foi suficiente para compensar as perdas ou desfinanciamento pela esfera federal. Ademais, o financiamento das unidades públicas deixa, progressivamente, de ser por orçamento global por série histórica, para um financiamento com base da produção de serviços realizados.

14 Segundo ALMEIDA (1999), a forma de alocação de recursos financeiros, como o realizado através da NOB 96, teria sido um instrumento indutor da reforma proposta pelo MARE. evidenciando a mudança de agenda reformadora setorial, numa perspectiva mais restritiva.
} 
Os novos modelos de gestão e de vinculação de recursos humanos já estão sendo experimentados pelos estados e municipios, tanto na organização do seu sistema local como nos seus hospitais e centros de saúde. Seguindo a temática da reforma, apontam o modelo administrativo burocrático como obstáculo à eficiência da gestão e reclamam a responsabilização das organizaçōes públicas na área da saúde. As mudanças na estrutura organizacional do setor saúde, induzidas pelas novas orientações imprimidas à reforma do Estado, estão centradas em variáveis intra-organizacionais e na experimentação de modelos alternativos de gestão. Para COSTA e MELO (1998), essas experiências que se situam na fronteira do modelo administrativo burocrático ou legal-formal, apontam para a rápida difusão de um padrão altamente flexivel de destinação de recursos estatais no mix público-privado. Ainda segundo esses autores, as inovações na gestão contemplam a possibilidade de contratação fora do Regime Jurídico Único, compras fora do rigor da Lei de Licitações, utilização de formas administrativas alternativas ao direito público e, em determinados casos, seleção de clientelas e instituição de formas de co-pagamento. No sistema local as inovações são, em sua maioria, a criação de gerências distritais e conselhos gestores de unidade, com participação da comunidade (GERSCHMAN 2001).

Especificamente no setor hospitalar, a crise da gestão pública hospitalar nessa década deveu-se à falta de alternativas que ampliassem a capacidade dessas organizações para responderem às novas demandas por qualidade e presteza no atendimento. Dentre os hospitais públicos, os universitários federais sofrem um impacto adicional: observa-se um panorama de 
desobrigação progressiva do MEC com estes hospitais. Em fins da década de 90, para COSTA et. al (2000) esse cenário parece mudar radicalmente devido à difusão da agenda da flexibilização administrativa. Essas mudanças, do ponto de vista microrganizacional, caracterizam-se por aumentar a eficiência gerencial, através da redução da autonomia médica ${ }^{15}$, do controle do trabalho e da infra-estrutura hospitalar, de novos métodos de controle de materiais e insumos e do maior controle dos pagadores, sejam gestores públicos de saúde, operadoras privadas ou negociadores de seguro social.

Entretanto, o setor saúde, mesmo quando inova seu modelo de gestão, em geral, tem adotado posturas normativas e eficientistas. Este fato parece estar historicamente conectado às suas raízes. FOUCAULT (1993), analisando o nascimento da medicina social, aponta que esta estaria ligada ao controle da saúde dos individuos e da população, seja através do ambiente como na medicina urbana francesa; de todo o corpo social como na medicina de estado alemã ou do corpo das classes mais pobres para torná-las mais aptas ao trabalho e menos perigosas às classes ricas, como na medicina social inglesa. O indivíduo e a população são dados simultaneamente como objetos de saber e alvos de intervenção da medicina graças à normalização destes corpos através de mecanismos disciplinares. Portanto, a saúde pública nasce

\footnotetext{
${ }^{15}$ Para COCHRANE (1985) e CONTADRIOPOULOS (1996), desde o triunfo da medicina cientifica, é a lógica profissional que domina a regulação do sistema de saúde, na medida que são os médicos que detêm o conhecimento e técnicas de cura. $A$ universalização dos serviços nos anos 60 e a incorporação do ambiente e hábitos da população no conceito de saúde, nos anos 70 , abriram espaço para o crescimento da lógica tecnocrática e política. Nesse período, a cobertura mais ou menos universal dos serviços e a elevação dos custos
} 
institucionalizada, normalizada e baseada em registros, o que facilitaria a adoção de posturas normativas e eficientistas ${ }^{16}$.

Pensar a proposta de reforma do Estado brasileiro (e setorial) nos anos 90 como portadora de um projeto especifico, apresentado como universal, e considerando os agentes destinatários da mesma, também como portadores de propostas historicamente construidas, e que a dominação permeia o conjunto da vida social, a resistência esta ai igualmente presente, não apenas de forma organizada, mas também sob formas 'surdas', 'implicitas', levou-nos a questionar se essa reforma de Estado que tem o conceito de eficiência como conceito chave teve impacto em uma instituição pública de saúde. A questionar, também, se os trabalhadores de saúde perceberam, incorporaram e redefiniram o conceito de eficiência e se resistiram às possíveis mudanças ocasionadas na instituição.

provocaram um enorme crescimento das despesas. A racionalidade e a eficiência dos serviços tornam-se palavras-chave.

${ }^{16}$ É interessante observar que o conceito de eficiência era o norteador do primeiro método de planificação em saúde no Brasil e América Latina: o método CENDES/OPS (Centro Nacional para o Desenvolvimento - Universidade Central da Venezuela) concebido e difundido, na década de 60 , por planejadores venezuelanos ligados à OPS. Era um método normativo, baseado na idéia de eficiência na utilização dos recursos. A intenção era operacionalizar alguma forma de cálculo da eficiência (como análise de custo-benefício) que pudesse auxiliar tanto o processo de definição de prioridades (entre danos e grupos da população) quanto o processo de escolha das técnicas programáticas (combinação de recursos). Foi criticado por seu conteúdo tecnocrático, não permitindo que se fizessem transparentes os conflitos de interesse e as relações de poder entre as classes e grupos sociais e como tais relações interferiam na realidade sanitária do país. O Método CENDES/OPS, embora proposto para ser desenvolvido no nível local, não apresentava nenhuma flexibilidade ou "permeabilidade" às diferentes realidades locais. Além disso, a questão das prioridades era tratada de acordo com um referencial economicista da análise custo-benefício, havendo um reducionismo econômico-eficientista. 


\section{OBJETIVOS}

\subsection{OBJETIVO GERAL}

Demonstrar que mudanças e adaptações a Reforma Setorial do Estado brasileiro nos anos 90 , tendo a eficiência como conceito chave, provocou nas instituições públicas de saúde e verificar se o conceito de eficiência foi percebido, apreendido, incorporado, resistido ou redefinido por trabalhadores do setor de saúde.

\subsection{OBJETIVOS ESPECIFICOS}

Analisar:

- o conceito de eficiência em documentos que divulgam a proposta de reforma de Estado, com destaque aos que se referem ao setor saúde;

- a difusão do conceito de eficiência num hospital público;

- como o hospital incorporou em sua organização o conceito de eficiência;

- em que áreas de sua estrutura organizacional (recursos humanos, produção, gestão) o conceito de eficiência foi incorporado ou teve maior impacto;

- os indicadores selecionados de produção e produtividade, entre 1994 e 2000 , que possam apontar alterações na eficiência da instituição;

- a percepção do conceito de eficiência pelos trabalhadores e gerência na organização do hospital, no seu ambiente de trabalho, nas relações entre chefias e funcionários e entre funcionários;

- a incorporação, resistência e redefinição do conceito de eficiência pelos trabalhadores e gerência; 


\section{PROCEDIMENTOS METODOLÓGICOS}

\subsection{DESENHO DO ESTUDO}

Partimos do pressuposto que todo conceito é histórico, constituido em determinado momento, por homens reais, concretos, com interesses e valores e que esses homens modificam o processo social e são por ele modificados. Reordenar todo o conjunto de conceitos implica uma totalidade em que prevaleça o movimento contraditório se fazendo, desfazendo, refazendo. Recuperar a totalidade é fazer com que o objeto apareça no emaranhado de suas mediações e contradições; é recuperar como esse objeto foi constituído, tentando reconstituir sua razão de ser ou aparecer a nós segundo seu movimento de constituição (VIEIRA et. al 1991).

Estes pressupostos guiaram-nos a dois caminhos na abordagem do tema: de um lado, examinamos como os formuladores e implementadores das políticas de reforma do Estado brasileiro estabeleceram, difundiram e buscaram legitimar um dos conceitos chave desta proposta, que procura forjar um novo rosto para o Estado e para a Administração Pública: o conceito de eficiência. De outro lado, cientes de que os processos sociais gerados, intencionais e não intencionais, inevitavelmente transformam preceitos, examinamos como os trabalhadores de saúde, agentes destinatários da proposta, percebem, incorporam, resistem e redefinem este conceito norteador. 


\subsubsection{O discurso da eficiência na proposta de reforma do Estado}

Para perceber como o conceito da eficiência foi sendo construído e difundido procuramos desmontar os discursos determinando quem fala, como fala, para quem fala (destinatário), direta ou indiretamente, de quem fala (direta ou indiretamente) e por quem fala. Como relembra VIEIRA et. al (1991:28) "a problematização do objeto se configura no transcorrer da pesquisa." Segundo essas autoras, problematizar é dar voz aos sujeitos históricos, num procedimento em que o pesquisador interroga os agentes sociais a partir de suas preocupações e de sua postura e deixa-se interrogar por esses agentes. A partir desse diálogo o pesquisador formula ou reformula seus próprios conceitos, e verifica que outros agentes deve abordar e que registros buscar.

Como fonte, privilegiamos os documentos de divulgação produzidos pelo Ministério da Administração e Reforma do Estado. Essa abordagem, ampla num primeiro momento, abrangeu os diversos campos como previdência, relações de trabalho, formas organizativas, encaminhando-se, sucessivamente, para a análise das propostas especificas do setor público de saúde. O periodo analisado compreendeu a produção elaborada entre 1994 e 1998. Estas datas marcam o nascimento do Ministério da Administração e Reforma do Estado e sua posterior transformação em Ministério do Planejamento, Orçamento e Gestão. 
Através da desmontagem do discurso da proposta de reforma do Estado estabelecemos as categorias significativas apresentadas, a seguir na Tabela 1 (CRESWELL 1998; CORBIN e STRAUSS 1998).

TABELA 1 Categorias significativas utilizadas na análise de documentos

\begin{tabular}{|c|c|c|}
\hline CATEGORIA & CONTEÚDO & CÓDIGO \\
\hline ORGANIZAÇÃO/ESTRUTURA & $\begin{array}{l}\text { Organograma } \\
\text { Estrutura de deliberação/execução } \\
\text { Mudanças organizacionais } \\
\text { Regimento }\end{array}$ & ORG \\
\hline MODELO ASSISTENCIAL & $\begin{array}{l}\text { Ensino } \\
\text { Pesquisa } \\
\text { Assistência }\end{array}$ & MAP \\
\hline GESTÃO & $\begin{array}{l}\text { Política gerencial } \\
\text { Centralização/descentralização } \\
\text { Reorganização administrativa }\end{array}$ & GT \\
\hline PÚBLICO & $\begin{array}{l}\text { Gratuito } \\
\text { Publicização } \\
\text { Cidadania } \\
\text { Coletivo }\end{array}$ & PUB \\
\hline FINANCIAMENTO & $\begin{array}{l}\text { SUS } \\
\text { Convênio/Plano } \\
\text { Convênios Governo Federal } \\
\text { Convênios Governo Estadual } \\
\text { Convênios Governo Municipal }\end{array}$ & FIN \\
\hline RELAÇÕES INSTITUCIONAIS & $\begin{array}{l}\text { Governo Estadual } \\
\text { Governo Municipal } \\
\text { Reitoria } \\
\text { Unidades acadêmicas } \\
\text { Relação com usuários } \\
\text { Sindicato }\end{array}$ & REINS \\
\hline RELAÇÕES DE TRABALHO & $\begin{array}{l}\text { Gestão conflito trabalho/gerência } \\
\text { Formas de contratação } \\
\text { Remuneração } \\
\text { Treinamento/Capacitação } \\
\text { Pagamento produtividade/incentivo } \\
\text { Carga horária } \\
\text { Concurso/seleção } \\
\text { Política de Recursos Humanos } \\
\text { Condições de trabalho }\end{array}$ & RT \\
\hline EFICIÊNCIA & $\begin{array}{l}\text { Produtividade } \\
\text { Redução de custo } \\
\text { Custo } x \text { benefício } \\
\text { Otimização de arrecadação } \\
\text { Otimização de leitos } \\
\text { Otimização de RH }\end{array}$ & EFI \\
\hline
\end{tabular}




\subsubsection{Percepção, incorporação, resistência e redefinição do conceito de eficiência pelos trabalhadores e gerência}

Para compreender como os agentes destinatários da proposta a percebem, incorporam, resistem e como redefinem o conceito de eficiência, realizamos um estudo de caso. Segundo BOURDIEU (apud GOLDENBERG 1998:35) a interrogação sistemática de um caso particular possibilita retirar dele as propriedades gerais ou invariantes, ocultas sob as aparências de singularidade.

Foi realizado o estudo do caso do Hospital das Clínicas da Universidade Federal de Minas Gerais (UFMG). Essa opção deveu-se à minha condição de docente do Departamento de Medicina Preventiva e Social da Faculdade de Medicina/UFMG, envolvida e interessada, tanto na formação de graduandos em medicina, quanto na formulação, implementação e critica às politicas do nosso hospital universitário.

Realizou-se a análise de como o conceito de eficiência se manifesta:

- nos vários tipos de textos produzidos na instituição em estudo (planos de gestão, atas de conselho deliberativos, seminários etc.), entre 1994 e $2000^{17}$. As categorias significativas reconhecidas no discurso da proposta de reforma do Estado (Tabela 1) foram confrontadas também com os documentos e textos produzidos pelo corpo diretivo do Hospital estudado.

\footnotetext{
17 A inclusão dos textos produzidos na instituição em estudo e de dados de produção e produtividade dos anos de 1999 e 2000 ocorreu por sugestão da direção do Hospital das Clínicas, que em 1998 iniciou um processo de mudança organizacional, definida em seminário realizado naquele ano. A inclusão de dados desses anos permitiu melhor compreensão das modificações ocorridas no Hospital das Clinicas.
} 
- no comportamento de indicadores selecionados de produção e produtividade (Tabela 2). Foi realizado um estudo retrospectivo/descritivo através da série cronológica, de 1994 a 2000, buscando detectar alterações dos indicadores durante o período. A seleção dos indicadores norteou-se na proposta de MEDICI e GIRARDI (1996) modificada por nós em trabalho anterior (CHERCHIGLIA et. al 1998) e nos estudos recentes de IBAÑEZ et. al (2001).

TABELA 2 - Indicadores selecionados de produção e produtividade

\begin{tabular}{|c|l|}
\hline & \multicolumn{1}{|c|}{$\begin{array}{l}\text { Número de Autorizaçăo de Internação } \\
\text { Hospitalar (AlH) } \\
\text { Valor da produção de AlH } \\
\text { Número de procedimentos ambulatoriais } \\
\text { Valor da produção ambulatorial }\end{array}$} \\
\hline \multirow{2}{*}{ PARTICIPAÇÃO NO SUS/BH } & $\begin{array}{l}\text { Número e valor das AlH, } \\
\text { Número e valor total e desagregado dos } \\
\text { procedimentos ambulatoriais }\end{array}$ \\
\hline PRODUTIVIDADE DA CAPACIDADE & $\begin{array}{l}\text { Número de leitos disponiveis } \\
\text { INSTALADA }\end{array}$ \\
\hline Púmero de AlH por leito disponivel \\
Valor da AlH por leito disponivel
\end{tabular}

- no discurso dos trabalhadores e gerência: como definem o conceito de eficiência, como o percebem na vida de Instituição, no ambiente de trabalho, nas relações entre gerência e trabalho e inter-trabalho e em 
suas próprias vidas e quais os mecanismos de resistência adotados. Para essas análises utilizamos entrevistas semi-estruturadas com o corpo diretivo e grupos focais com os trabalhadores.

\subsection{UNIVERSO DE ESTUDO, GRUPOS E PESSOAS OBSERVADAS}

O Hospital das Clínicas da Universidade Federal de Minas Gerais (HC/UFMG) é um hospital geral (Universitário e Público) vinculado à Reitoria (art. 79, I do Estatuto da UFMG), órgão autárquico e suplementar da Universidade Federal de Minas Gerais. Dispondo de quadro próprio de pessoal, configura-se como Unidade Gestora, sendo os seus Diretores ordenadores de despesas. Tem como missão institucional o ensino, a pesquisa e a assistência médica.

O Hospital das Clínicas/UFMG foi inaugurado em 21 de agosto de 1928, a partir do agrupamento de algumas clínicas que foram surgindo ao redor da Faculdade de Medicina. Hoje, é um complexo hospitalar, composto por um Edificio Central, destinado às internações, e outros sete edifícios ou anexos que compõem o Setor Ambulatorial do Hospital. Tem capacidade instalada para 550 leitos, estando efetivamente em funcionamento, 385 leitos. 0 Hospital das Clínicas oferece serviços diagnósticos e terapêuticos hospitalares e ambulatoriais em seus 24 serviços ou especialidades, os quais, se dividem em subespecialidades. Conta ainda, com uma Unidade de Emergência, inaugurada em junho/96, para atendimento de urgência médico-cirúrgica não traumatológica. 
O Hospital atende, predominantemente aos pacientes do Sistema Único de Saúde - SUS (Municipal, Regional e Estadual), que correspondem a 90\% de sua clientela; atende também pacientes particulares e de convênios. A prestação de serviços ao SUS é sua principal fonte de arrecadação.

O quadro de pessoal do Hospital das Clínicas, em 2000, era constituído por 2545 funcionários. São 1552 (61\%) servidores estatutários pertencentes ao quadro da UFMG e regidos pelo Regime Jurídico Único. Já os funcionários vinculados à Fundação de Desenvolvimento da Pesquisa - FUNDEP representam cerca de $34 \%$ (862 funcionários), sendo que 576 (67\%) são trabalhadores celetistas, com regime de trabalho regido pela Consolidação das Leis Trabalhistas, e 286 (33\%) são profissionais autônomos vinculados à duas cooperativas de trabalho: a Cooperativa de Trabalho dos Médicos do Hospital das Clinicas da UFMG (HC-COOP) e à Cooperativa de Trabalho dos Profissionais de Informática e em Serviços Logisticos Ltda (MULTICOOP). Conta também com trabalhadores do governo federal em disponibilidade no $\mathrm{HC}$ e bolsistas da Fundação Mendes Pimentel e Cruz Vermelha (5\%). É interessante observar que os 1552 funcionários vinculados à UFMG correspondem, aproximadamente, a $25 \%$ do total de servidores técnico-administrativos da universidade. Além das categorias apontadas, o Hospital possui os seguintes serviços terceirizados: Limpeza, Portaria e Vigilância. Conta ainda com 377 docentes; 1296 alunos (medicina, enfermagem, fonoaudiologia, fisioterapia, terapia ocupacional, farmácia e psicologia), 98 alunos de especialização e 241 residentes. Estão em 
andamento, no Hospital, 254 dissertações de mestrado e 111 teses de doutorado.

O universo amostral foi constituído pelos 2545 trabalhadores (exceto os terceirizados) e 377 professores que exercem atividades no HC/UFMG.

\subsection{TÉCNICA DE OBSERVAÇÃO DOS INDICADORES - COLETA DE DADOS}

\subsubsection{Levantamento Bibliográfico}

No levantamento bibliográfico, utilizaram-se as bases de dados Medline e Lilacs, para a área médica, e a de dados Wilson, para a área da administração. Foram pesquisadas as palavras chaves: eficiência, reforma do estado, governança, administração pública, administração gerencial, produtividade, relações de trabalho, hospital público, hospital escola, hospital universitário. Foram pesquisadas, também, várias bibliotecas virtuais que versam sobre o assunto como a da OIT (Organização Internacional do Trabalho), a "Red de gobernabilidad y desarrollo institucional en America Latina", Banco Mundial/BIRD, "National Bureau of Economic Research", periódicos CAPES, buscando-se textos afins disponibilizados por essas organizações. Os artigos e livros foram lidos, resumidos e armazenados em meio magnético, para acesso rápido da informação selecionada.

A produção normativa foi obtida nas páginas eletrônicas dos Ministérios de Planejamento e Gestão, Previdência Social e do Trabalho ${ }^{18}$, bem como na página eletrônica específica sobre legislação mantida pelo Senado Federal 
Brasileiro $^{19}$. O levantamento da legislação teve como ponto de partida as mudanças constitucionais e infraconstitucionais propostas no Plano Diretor da reforma do aparelho de estado. Buscaram-se as alterações e propostas de alterações normativas contemplando a previdência social, a administração e os servidores públicos, as novas formas de organização e de gestão do setor público.

\subsubsection{Levantamento Documental}

Os documentos e textos sobre a reforma produzidos pelo Ministério da Administração e Reforma do Estado (MARE) foram obtidos diretamente na página eletrônica do atual Ministério de Planejamento e Gestão ${ }^{20}$, sendo convertidos para arquivos de textos e resumidos.

O levantamento sobre a história do Hospital das Clínicas revelou-se uma tarefa árdua, e muitas vezes infrutifera devido à escassez de dados e documentos. A pouca informação encontrada está vinculada à história da Faculdade de Medicina, à qual esteve formalmente ligado até a década de setenta. Além disto, só foram encontradas cópias físicas dos documentos oficiais como planos diretores e relatórios de seminários realizados. Estes tiveram que ser digitalizados. As atas do Conselho Administrativo do Hospital das Clínicas foram também catalogadas e analisadas.

\footnotetext{
${ }^{18} \mathrm{http}: / /$ unw.mpas.gov.br/11_01htm

${ }^{19} \mathrm{http}: / / \mathrm{www}$. senado.gov.br/legisla.htm

${ }^{20} \mathrm{http}: / / \mathrm{ww}$. planejamento.gov.br
} 


\subsubsection{Indicadores de Produção}

Os dados para a construção dos indicadores de produção hospitalar e ambulatorial, e seus respectivos valores, foram obtidos das Autorizações de Internação Hospitalar (AIH) e do Sistema de Informação Ambulatorial (SIA) do consolidado produzido pelo DATASUS/Ministério da Saúde. Selecionouse esta fonte por ser o documento de faturamento ao órgão remunerador/financiador dos serviços de saúde. A AlH e o SIA são totalmente informatizados, permitindo um resgate mais detalhado e confiável através de meio magnético. Todos os dados sobre valor estão em Real, corrigidos pelo Índice de Preço ao Consumidor do Instituto Brasileiro de Geografia e Estatística - IPCA/IBGE. Os dados de produção hospitalar e ambulatorial dos serviços prestados ao SUS pelo Hospital das Clínicas foram cotejados com os da produção do municipio de Belo Horizonte, para permitir visualizar-se a participação do Hospital das Clinicas no "mercado SUS" municipal de prestação de serviços. Além disto, foram levantados os dados de produção do Hospital das Clínicas para pacientes particulares e convênios com os planos de saúde, a arrecadação total e despesas desagregadas, e dados qualitativos como: média de permanência, taxa de ocupação e de infecção hospitalar. $\mathrm{Na}$ arrecadação total os valores referentes à prestação de serviços ao SUS (hospitalar e ambulatorial) correspondem ao montante efetivamente recebido pelo $\mathrm{HC}$ no ano. Assim, estão incluidas as parcelas devidas pelo reajuste, de $25 \%$, da Tabela de Procedimentos retroativa a maio de 1995, além do pagamento de procedimentos realizados, em campanhas, para o MS como, por exemplo, o 
mutirão de catarata. Os indicadores sobre recursos humanos (número de trabalhadores por categoria, taxa de absenteismo) foram coletados do sistema formal de registro, através do consolidado das atividades do Departamento de Recursos Humanos do Hospital das Clinicas/UFMG. O estudo de confiabilidade das observações nos registros realizou-se mediante exames de consistência inter-observadores.

\subsubsection{Indicadores de Percepção ${ }^{21}$}

Foi desenvolvido e testado o roteiro de entrevista semi-estruturada, a ser feita com o nivel diretivo (ANEXO1). Foram realizadas 23 entrevistas: com os diretores atuais - três entrevistas - (diretor geral, clínico, administrativo, de pesquisa e extensão); com os ex-diretores com mandatos desde 1988 (cinco entrevistas); com as chefias intermediárias (cinco administrativas, quatro clinicas e a coordenação de enfermagem), e com o atual e com dois ex-presidentes do Conselho Administrativo do Hospital das Clinicas diretores da Faculdade de Medicina (três entrevistas).

Foi desenvolvido e testado o roteiro para os grupos focais (ANEXO 2). Para a análise da percepção dos trabalhadores foram constituídos grupos pequenos (6-10 pessoas) de composição heterogênea (KRUEGER e CASEY 2000), tomando em consideração as seguintes variáveis: profissão de base; vínculo empregaticio; posição funcional e especialidade médica.

\footnotetext{
${ }^{21}$ Percepção é definida por SCHIFFMAN e KANUK (1991) como o processo pelo qual um individuo seleciona, organiza e interpreta os estímulos, com o objetivo de formar representaçōes significativas e coerentes da realidade.
} 
A escolha aleatória dos integrantes foi feita a partir do cadastro de profissionais do Departamento de Recursos Humanos do Hospital das Clinicas. Os integrantes de cada grupo foram voluntários, selecionados a partir da disponibilidade e interesse em participar dos grupos. Procurou-se contar, nos diferentes grupos, com trabalhadores representantes das diversos setores, que estivessem exercendo atividades no Hospital há pelo menos 4 anos.

Constituição dos Grupos:

Grupo 1 - Médicos de diferentes especialidades: clínica médica (01), pediatria (01), anestesiologia (01); cirurgia (01) neonatologista (01); ginecologia (01); pneumologia (1);

Grupo 2 - Profissionais de nivel superior em serviços de saúde: enfermeiro (03); assistente social (01), farmacêutico (01), fisioterapeuta (01), psicólogo (01), nutricionista (01), terapeuta ocupacional (01);

Grupo 3 - Profissionais auxiliares de enfermagem e outros auxiliares do serviço de apoio ao diagnóstico e terapêutica - SADT: auxiliar/técnico de enfermagem (03), técnico-radiologista (01), técnico-laboratorista (01), técnico em nutrição (01), técnico em farmácia (01);

Grupo 4 - Grupo administrativo: auxiliares administrativos de diferentes setores: financeiro (02), enfermarias (01), serviço de nutrição e dietética (01), setor de convênios (01), farmácia (01), ambulatórios (01), lavanderia (01), serviço de imaginologia (01), serviço de fonoaudiologia (01);

Grupo 5 - Grupo de serviços gerais: auxiliares de nivel elementar de diferentes setores: portaria (02), infra-estrutura (01), manutenção (02), serviços gerais (01), lavanderia (01), serviço de nutrição e dietética (02). 


\subsection{Procedimentos para a garantia de aspectos éticos}

Os integrantes voluntários de cada grupo foram selecionados, sem distinção de sexo, cor ou raça. A lista dos participantes voluntários foi de domínio único e exclusivo da equipe de pesquisa (pesquisadora e auxiliares de pesquisa e/ou estagiários). As reuniões dos grupos foram realizadas fora do Hospital das Clínicas, em horário conveniente aos participantes, garantindoIhes lanche.

As entrevistas semi-estruturadas com a diretoria, grupo assessor e gerência intermediária foram agendadas e realizadas conforme disponibilidade de tempo dos entrevistados. A maioria dos entrevistados preferiu fazer a entrevista em seu ambiente de trabalho.

Os participantes das entrevistas e do grupo focal do hospital estudado foram previamente esclarecidos sobre os objetivos da pesquisa, dos possiveis beneficios como a melhoria da qualidade do trabalho no dia-a-dia do hospital, do serviço prestado à população, sobre a garantia de sua privacidade, confidencialidade e anonimato das opiniões e idéias expressadas e de que poderiam recusar-se a participar, ou retirar-se, sem necessidade de consentimento, em qualquer fase da pesquisa, sem que isso Ihes trouxesse qualquer constrangimento. Foram informados, também, que os resultados da pesquisa, aos quais terão livre acesso, serão apresentados em Seminário no Hospital das Clínicas e divulgados em artigos científicos e Congressos. Após os esclarecimentos assinaram o "Termo de Consentimento Livre e Esclarecido" (ANEXO 3). 
Estas entrevistas e grupos focais foram gravados, sem identificação e, tão logo transcritas, as fitas foram apagadas, mantendo-se o anonimato e confidencialidade. Todos os procedimentos de observação (entrevistas, grupos focais) foram realizados pela pesquisadora e sua equipe.

\subsection{MODELO DE ANÁLISE}

Todo o material documental foi catalogado e analisado tendo como referencial as categorias significativas de análise, previamente estabelecidas (Tabela 1). Os indicadores numéricos de produção de serviços foram cotejados em sua evolução temporal. Os indicadores de produção do trabalho, expressos como relação ou proporção $\left(\mathrm{n}^{\circ}{ }^{\circ}\right.$ total de $\mathrm{AlH} /$ total recursos humanos; valor médio da AlH/ano, etc.), foram analisados comparando-se estas proporções na série temporal. Os diversos indicadores de produção do trabalho estão apresentados em tabelas, em números absolutos e relativos, comparando-se sua variação no tempo, tendo como base o ano de 1994 ou a diferença entre cada ano. A evolução temporal dos indicadores de produção de serviços e produtividade foi estudada através da análise descritivo/qualitativa.

As observações dos Grupos Focais e das entrevistas foram registradas e desagregadas utilizando-se as categorias significativas para facilitar a codificação e análise dos dados. Foram elaboradas tábuas qualitativas, com categorias e palavras chave, confrontando a percepção dos dirigentes e trabalhadores, dos diferentes grupos de trabalhadores e destes com o discurso dos formuladores da proposta. 


\section{RESULTADOS}

\subsection{O CONCEITO DE EFICIÊNCIA NA REFORMA DO ESTADO}

\subsubsection{Análise das categorias significativas nos documentos do MARE}

$\mathrm{Na}$ Tabela 3, apresentamos a sintese das categorias significativas analisadas nos documentos elaborados pelo MARE, ou artigos escritos por seus ministros.

A reorganização do Estado baseia-se numa revisão de suas funções e forma de organização, considerando os tipos de gestão e as formas de propriedade mais adequadas. São definidos quatro setores, com três formas de propriedade: núcleo estratégico (estatal); setor de atividades exclusivas de Estado (estatal); setor de serviços não-exclusivos ou competitivos (pública não-estatal); setor de produção de bens e serviços para o mercado (gestão privada). A cada setor corresponderia um princípio orientador e uma forma de gestão. No núcleo estratégico, o essencial é a correção das decisões tomadas o principio administrativo fundamental é o da efetividade e a forma de gestão seria um misto de administração pública burocrática e gerencial. Nos setores das atividades exclusivas, de serviços competitivos ou não-exclusivos, e de produção de bens e de serviços para o mercado (gestão privada), o importante seria a qualidade e o custo dos serviços prestados aos cidadãos. O princípio correspondente é o da eficiência, portanto, a administração deveria ser gerencial. 
Segundo o MARE, o paradigma gerencial contemporâneo para a nova administração pública, se fundamentaria nos princípios da confiança e da descentralização da decisão, exigindo formas flexíveis de gestão, horizontalização de estruturas, descentralização de funções e controle por resultados. O cidadão é visto como contribuinte de impostos e como cliente dos serviços. As relações com os trabalhadores se dariam de forma flexivel e através do comprometimento com avaliação sistemática, recompensa pelo desempenho e capacitação permanente. Contrapõe-se, desta maneira, à ideologia do formalismo, procedimentalismo e do rigor técnico da burocracia tradicional.

A administração gerencial permitirá estabelecer maior democratização da administração pública. Segundo esta perspectiva, supõe-se que o cidadão, igualado a usuário de serviços, poderá expressar suas preferências de maneira mais adequada através do mercado. A burocracia "orientada para o cliente" torna-se fundamento de uma administração mais democrática, na medida em que implica uma ligação mais estreita entre as preferências do público e a prestação de serviços. A participação do usuário em comitês de avaliação e a realização de pesquisas para medir a satisfação dos clientes são mecanismos complementares para garantir a qualidade dos serviços prestados e o correto funcionamento do aparelho burocrático.

A proposta de financiamento obedece ao receituário dos organismos internacionais de redução do déficit fiscal: contenção da demanda pela redução dos gastos públicos; realocação de recursos visando gerar superávits na balança comercial e reformas nas politicas para aumentar a eficiência em longo 
prazo do sistema econômico. Desta forma, a agenda do financiamento das políticas públicas passa a ser dada por: aumento da focalização do gasto público (instituição de cobrança dos que podem pagar e o estimulo à oferta pelo setor privado de certos serviços); descentralização da execução dos programas sociais para estados e municipios; desvinculação entre fonte de financiamento e provisão de serviços; fortalecimento do papel do governo federal no controle de qualidade e provisão de informação ao consumidor.

As relações de trabalho serão diferenciadas de acordo com as competências dos novos setores do Estado. Assim, os servidores públicos estáveis e, portanto, integrantes de carreiras de Estado, serão apenas aqueles cujas atividades estão voltadas para as atividades exclusivas de Estado relacionadas com a formulação, controle e avaliação de políticas públicas e com a realização de atividades que pressupōem o poder de Estado. Esses servidores representarão o Estado enquanto pessoal. Os profissionais atuando na área de serviços sociais e cientificos (que será transferida mediante o processo de publicização para entidades de direito privado sem fins lucrativos integrantes do setor público não-estatal) e em setores voltados para a produção de bens e serviços para o mercado serão administrados com base em regras vigentes para o setor privado, não se constituindo em funcionários públicos. Não teriam mais, portanto, o direito à estabilidade. $\mathrm{O}$ mesmo se aplica para os profissionais atuando em setor que será transferido do Estado para o setor privado por meio do processo de privatização. Para a realização de atividades auxiliares como manutenção, segurança e 
atividades de apoio diversas, será dada continuidade ao processo de terceirização, transferindo-as para entidades privadas.

A revisão da remuneração seria complementada com o aperfeiçoamento dos instrumentos que associam incentivos ao desempenho do servidor, em conformidade com os princípios da administração gerencial, voltada para resultados. Daí decorre a importância que é atribuída, nessa perspectiva gerencial, aos instrumentos de avaliação permanente e de valorização de desempenho dos funcionários. A valorização do servidor público se daria por meio de sua capacitação permanente, com o objetivo de contribuir para a melhoria da eficiência do serviço público e da qualidade dos serviços prestados aos cidadãos e permitir a constante adequação da força de trabalho às necessidades do Governo Federal. 
TABELA 3 - Sintese das categorias analisadas nos documentos produzidos pelo MARE, Brasil, 1995-1998

\begin{tabular}{|c|c|c|c|c|c|}
\hline Organizaçào/Fstrutura & Gestăo & Público & Financiamento & Relaçes de Trabalho & Fficiência \\
\hline 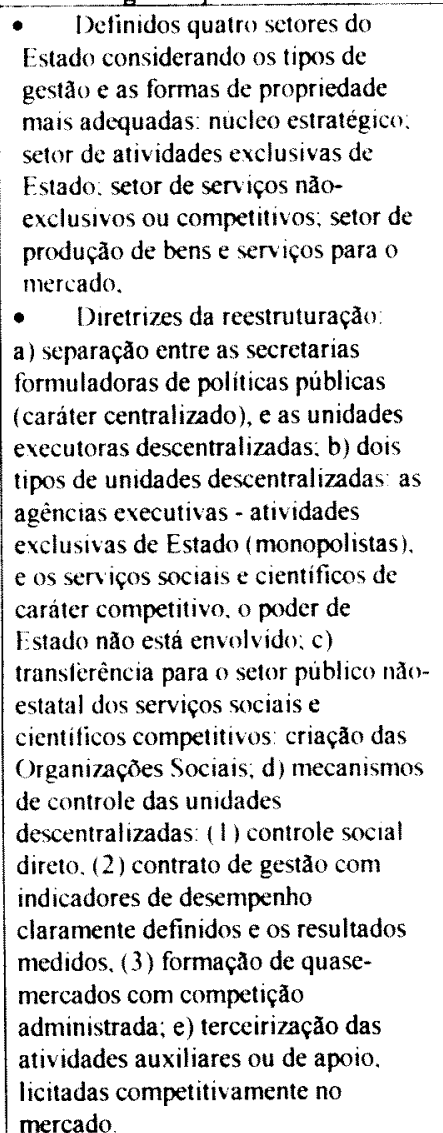 & 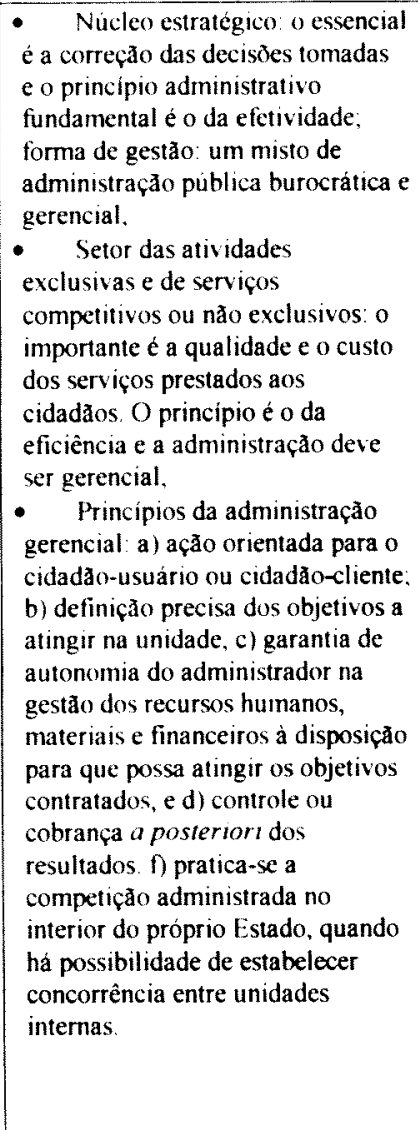 & $\begin{array}{l}\text { Programa de publicizaçào. } \\
\text { transfere-se para o setor publico } \\
\text { não-estatal a produção dos } \\
\text { serviços competitivos ou nåo- } \\
\text { exclusivos de Estado. sistema de } \\
\text { parceria entre Estado e sociedade } \\
\text { para seu financiamento e controle } \\
\text { - A estratégia de publicizaçăo } \\
\text { visa a aumentar a eficiència e a } \\
\text { qualidade dos serviços, } \\
\text { atendendo melhor o cidadåo* } \\
\text { cliente a um custo menor } \\
\text { - Participaçăo direta da } \\
\text { sociedade (controle social) na } \\
\text { gestão pública: participaçăo nos } \\
\text { conselhos de administração dos } \\
\text { diversos segmentos } \\
\text { representativos da sociedade } \\
\text { civil. }\end{array}$ & $\begin{array}{l}\text { - Nucleo estratégico e setor } \\
\text { das atividades exclusivas: estatal, } \\
\text { financiado pelo Istado } \\
\text { (orçamento); } \\
\text { - Setor de serviços } \\
\text { competitivos ou não exclusivos: } \\
\text { financiado pelo Estado (mas nåo } \\
\text { sło estatal); venda de serviços e } \\
\text { doaçöes por parte da sociedade. }\end{array}$ & 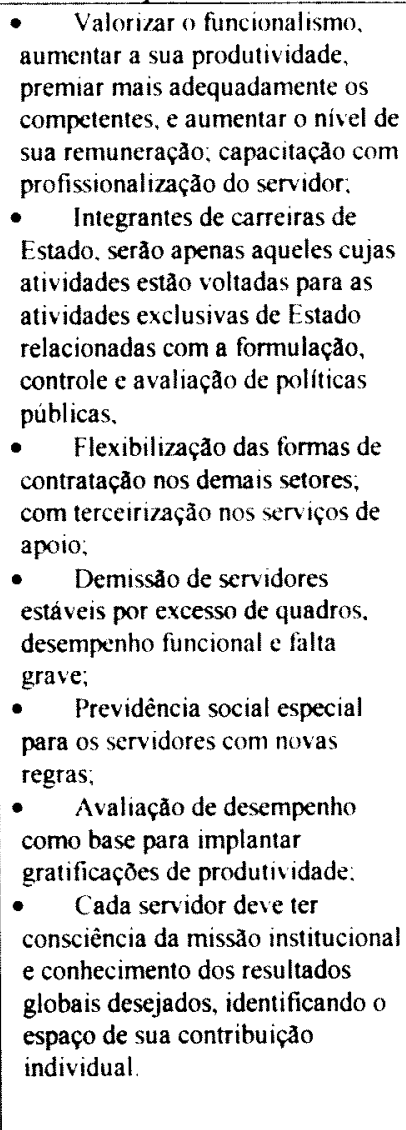 & 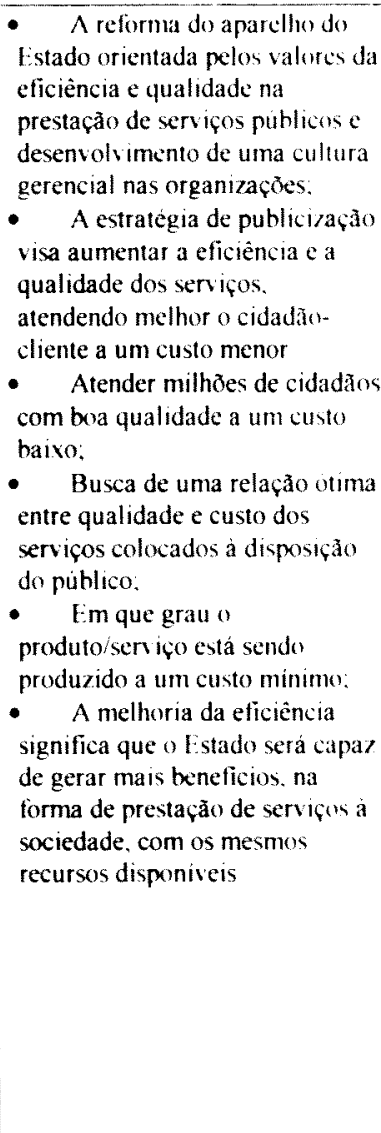 \\
\hline
\end{tabular}

Fonte: Brasil. 1995. Ministério da Administração e Reforma do Estado. Plano Diretor da Reforma do Estado e Cadernos do MARE. Brasilia: c.1 a c.17 


\subsubsection{O conceito de eficiência nos documentos elaborados pelo MARE}

No Plano Diretor o vocábulo eficiência e seus correlatos (eficiente,

ineficiência, ineficiente) são citados 43 vezes. Observamos que o conceito de eficiência é um dos conceitos chave na redefinição do papel do Estado, pois o atendimento eficiente das demandas de seus cidadãos seria uma questão universal de todos os governos democráticos;

"É importante ressaltar que a redefinição do papel do Estado é um tema de alcance universal nos anos 90. No Brasil esta questão adquiriu importância decisiva, tendo em vista o peso da presença do Estado na economia nacional: tomou-se, consequentemente, inadiável equacionar a questão da reforma ou da reconstrução do Estado, que já não consegue atender com eficiência a sobrecarga de demandas a ele dirigidas, sobretudo na área social. A reforma do Estado não é, assim, um tema abstrato: ao contrário, é algo cobrado pela cidadania, que vê frustrada suas demandas e expectativas" (BRASIL 1995. Plano Diretor da Reforma do Aparelho de Estado, p.6).

"A eficiência da administração pública - a necessidade de reduzir custos e aumentar a qualidade dos serviços, tendo o cidadão como beneficiário - toma-se então essencial. A reforma do aparelho do Estado passa a ser orientada predominantemente pelos valores da eficiência e qualidade na prestação de serviços públicos e pelo desenvolvimento de uma cultura gerencial nas organizações" (BRASIL 1995. Plano Diretor da Reforma do Aparelho de Estado, p.10).

"O objetivo da reforma é permitir que a administração pública se tome mais eficiente e ofereça ao cidadão mais senviços, com maior qualidade. Ou seja, fazer mais e melhor com os recursos disponíveis. A redução de custos será perseguida ao mesmo tempo em que se promove a continua revisão e aperfeiçoamento das rotinas e processos de trabalho, simplificando procedimentos, desburocratizando e estabelecendo metas e indicadores de desempenho e de satisfação do cidadão" (BRASIL 1997. Cadernos MARE da reforma do estado; c.6, p.10).

“(...) A realidade é que o Estado, desde que bem administrado, pode ser tão eficiente na sua esfera de atuação quanto uma empresa privada. E não se trata de cortar custos, como muitos supõem. A questão não é gastar menos e sim gastar melhor" (BRASIL. 1997. Cadernos MARE da reforma do estado; c.7, p.19; artigo da Ministra Cláudia Costin) 
A Tabela 4 apresenta os termos mais correlacionados ao conceito de eficiência, ou a ele contrapostos (ineficiência), nos documentos analisados.

TABELA 4 - Objetivos e valores da reforma do aparelho de Estado (administração pública) correlacionados ao conceito de eficiência (eficiente) ou a ele contrapostos (ineficiência).

\begin{tabular}{|l|l|}
\hline \multicolumn{1}{|c|}{ Eficiência (Eficiente) } & \multicolumn{1}{|c|}{ Ineficiência (Ineficiente) } \\
\hline Gerencial & Burocrática \\
Flexivel/flexibilidade & Rígida \\
Atendimento do cidadão/cliente & Auto-referenciada \\
Redução de custos & Burocratização dos procedimentos \\
Definição clara de objetivos & Padrões hierárquicos rígidos \\
Valores e comportamentos modernos & Arcaica, refratária às inovações \\
Participação & Classista \\
Controle dos resultados & Enfase no controle de processos \\
Descentralização & Centralização das decisões \\
Democrático & Autoritária \\
Racional & Excesso de formalismo \\
Responsabilização & Ausência de Responsabilização \\
Controle social & Capturada por interesses \\
Autonomia & Ausência de autonomia \\
Avaliação de desempenho & Voltada para o controle administrativo \\
Conhecimento da missão institucional & Voltada para si própria e para o controle \\
interno \\
Profissional & Sistemas hierárquicos baseados na unidade \\
de comando. \\
Atende as necessidades da sociedade & Desempenho institucional insatisfatório \\
Punição para os que falarem ou prevaricarem & Extensão do regime estatutário para todos os \\
Gervidores civis (estabilidade) \\
Aumento da qualidade & \\
Mercado & \\
Informação & \\
Competição administrada & \\
Equidade & \\
Otimização & \\
\hline Fonte:BRASI & \\
\hline
\end{tabular}

Fonte: BRASIL. Ministério da Administração e Reforma do Estado. Plano Diretor da Reforma do Estado e Cademos do MARE. Brasília: c.1 a c.17. 
O conceito de eficiência que pode ser apreendido da coletânea de documentos produzidos pelo MARE parece expressar, fundamentalmente, sua raiz econômica, ou seja, a relação de que a um gasto de energia, insumo ou input deve-se obter um resultado, produto ou output. Desta forma, eficiência é assim definida pelo MARE: "em que grau o produto/serviço está sendo produzido a um custo minimo" (BRASIL 1998. Cadernos MARE da reforma do estado. c.2, p.28). Portanto, a eficienncia buscada é explicitamente econômica;

“(.) a melhoria da eficiência significa que o Estado será capaz de gerar mais beneficios, na forma de prestação de serviços à sociedade, com os mesmos recursos disponiveis. Ou seja, o Governo entende que o problema não é simplesmente de cortar gastos, mas gastar com eficiência e responsabilidade o que se tem" (BRASIL 1997. Cadernos MARE da reforma do estado; c.6, p.10).

"É preciso, mais do que tudo, incorporar definitivamente ao serviço público práticas inquestionáveis de eficiência e justiça social. A primeira, mediante análise de custo-beneficio; a segunda, mediante comprovação da necessidade dos senviços pela população a ser atendida. Caso contránio, continuaremos, ad infinitum, gastando muito e gastando mal" (BRASIL 1997. Cadernos MARE da reforma do estado; c.7, p.19; artigo da Ministra Cláudia Costin).

"Dar prionidade a programas e ações que aumentem a eficiência do gasto público, mediante redução dos desperdícios, adequação das estruturas organizacionais e elevação da qualidade e da produtividade dos senviços públicos" (BRASIL 1997. Cadernos MARE da reforma do estado; c.5, p.32).

É interessante notar que a forma de apresentação e a amplitude do conceito de eficiência nos objetivos, princípios e estratégias da reforma do Estado apesar de estar centrada no econômico estaria, também, conectada ao conceito de democracia e cidadania; 
“(..) Esta lógica do leque de controle, que orienta a reforma do Estado, tem, portanto, um caráter histórico, ao mesmo tempo em que obedece a alguns principios gerais: o principio da maior democracia, o princípio da maior difusão do poder, o princípio econômico da eficiência, o principio da maior automaticidade dos controles, o principio do aumento do espaço público não-estataf" (BRESSER PEREIRA 1997. Cadernos MARE da reforma do estado; c.1, p.39).

"É preciso, agora, dar um salto adiante, no sentido de uma administração pública que chamaria de "gerencial", baseada em conceitos atuais de administração e eficiência, voltada para $o$ controle dos resultados e descentralizada para poder chegar ao cidadão, que, numa sociedade democrática, é quem dá legitimidade às instituições e que, portanto, se toma "cliente privilegiado" dos serviços prestados pelo Estado" (BRASIL 1995. Plano Diretor da Reforma do Aparelho de Estado, p.4).

"A administração pública gerencial vê o cidadão como contribuinte de impostos e como cliente dos seus senviços. Os resultados da ação do Estado são considerados bons não porque os processos administrativos estão sob controle e são seguros, como quer a administração pública burocrática, mas porque as necessidades do cidadão-cliente estão sendo atendidas" (BRASIL 1995. Plano Diretor da Reforma do Aparelho de Estado, p.11).

$\mathrm{Na}$ maioria das vezes vemos que ao conceito econômico é agregado o de qualidade, ampliando o conceito de eficiência e relacionando-o, novamente, ao de cidadão-cliente;

“(...) Em sintese, a estratégia de publicização visa a aumentar a eficiência e a qualidade dos serviços, atendendo melhor 0 cidadão-cliente a um custo menor (...)" (BRESSER PEREIRA 1997. Cadernos MARE da reforma do estado; c.1 p.12).

"No setor das atividades exclusivas e de senviços competitivos ou não exclusivos, o importante é a qualidade e o custo dos serviços prestados aos cidadãos. O princípio correspondente é o da eficiência, ou seja, a busca de uma relação ótima entre qualidade e custo dos serviços colocados à disposição do público" (BRASIL 1995. Plano Diretor da Reforma do Aparelho de Estado, p.27).

“(...) Nesta área o essencial não é a adequação e efetividade das normas, mas a eficiência dos serviços prestados. Ou seja, os serviços devem ter maior qualidade ao mesmo custo" (BRASIL 1997. Cadernos MARE da reforma do estado; c.7, p.56 - Ministro Bresser Pereira) 
"O objetivo da reforma é permitir que a administração pública se tome mais eficiente e ofereça ao cidadão mais senviços, com maior qualidade. Ou seja, fazer mais e melhor com os recursos disponiveis" (BRASIL 1997. Cadernos MARE da reforma do estado; c.6, p.10).

Um objetivo, também central na reforma do Estado brasileiro nos anos 90, é a construção da capacidade de ação eficiente do estado, entendida como governança. Portanto, estes dois princípios - governança e eficiência deveriam estar sempre presentes no desenho das novas formas institucionais e modelos de gestão ou em qualquer ação da cooperação estatal. Ocorreria uma permuta (trade off), entre os conceitos de governança e eficiência;

"Aumentar a govermança do Estado, ou seja, sua capacidade administrativa de govemar com efetividade e eficiência, voltando a ação dos serviços do Estado para o atendimento dos cidadãos" (BRASIL 1995. Plano Diretor da Reforma do Aparelho de Estado, p.7).

"(...) a reforma do aparelho do Estado, com vistas a aumentar sua "govemança", ou seja, sua capacidade de implementar de forma eficiente politicas públicas de maneira conjugada com a sociedade (...)" (BRASIL 1995. Plano Diretor da Reforma do Aparelho de Estado, p.29 e Cadernos MARE da reforma do estado; c.1, p.9).

“O objetivo central é o de reforçar a govemança, através da transição programada de um tipo de administração pública burocrática, rigida e ineficiente, voltada para si própria e para o controle intemo, para uma administração pública gerencial, flexivel e eficiente, voltada para o atendimento do cidadão. $O$ conceito de govemança se refere à capacidade do Estado de transformar as decisões politicas do Governo em medidas" (BRASIL 1998. Cadernos MARE da reforma do estado; c.12, p.13).

Em outros momentos este conceito relaciona-se ao que é moderno ou simplesmente com o alcance de resultados;

“(..) Já a modermização ou o aumento da eficiência da administração pública será o resultado, em médio prazo, de um complexo projeto de reforma, (...)" (BRASIL 1997. Cadernos MARE da reforma do estado; c.3, p.24).

“(..) Mas o controle a priori é ineficiente. A forma moderna de obter bons resultados é garantindo liberdade às organizações e 
controlando a posteriori os resultados alcançados, através da avaliação. O controle a priori - o controle dos processos - esse sim é burocrático, autoritário, além de ineficiente. $E$ a forma generalizadamente adotada no Brasil do passado. Resulta no descontrole e no desperdicio. É um sistema de esconder ou disfarçar a incompetência e o mau desempenho, que é incompativel com o Brasil novo que os brasileiros querem construir com Femando Henrique Cardoso" (BRASIL 1997. Cadernos MARE da reforma do estado; c.7, p.70 - Ministro Bresser Pereira).

Como uma das propostas centrais da reforma do Estado era a denominada "reforma administrativa" que, alteraria profundamente as relações de trabalho entre o Estado e seus servidores, o conceito de eficiência (ineficiência) aparece várias vezes ligado ao de bom (ou mau) servidor e com a produtividade de seu trabalho;

"O objetivo da reforma só pode ser valorizar o funcionalismo, aumentar a sua produtividade, premiar mais adequadamente os mais competentes, e aumentar o nivel de sua remuneração. Hoje o funcionalismo público vive o círculo vicioso da estabilidade, a ineficiência e a baixa remuneração" (BRASIL 1997. Cadernos MARE da reforma do estado; c.7, p.10 - artigo do Ministro Bresser Pereira)

"Todo servidor competente e trabalhador, que valoriza seu próprio trabalho, será beneficiado. Saberá que está realizando uma tarefa necessária. E, ao mesmo tempo, readquirirá o respeito da sociedade - um respeito que foi perdido quando uma minoria de funcionários desinteressados, cujo trabalho não podia ser cobrado, estabeleceu padrões de ineficiência e mau atendimento para todo o funcionalismo" (BRASIL 1997. Cadernos MARE da reforma do estado; c.3, p.33).

"A valorização do servidor público (cliente interno) é uma garantia ao cumprimento da missão da Administração Pública de atender com qualidade aos seus clientes extemos - o cidadão. A valorização será função: da conscientização, pelo servidor, do sentido e do valor de sua missão; da profissionalização do serviço público; da avaliação do desempenho por resultados, a partir de objetivos bem definidos; do reconhecimento do mérito" (BRASIL 1997. Cadernos MARE da reforma do estado; c.4, p.20). 
Segundo os documentos do MARE, uma forma de aumentar a eficiência da administração pública seria a descentralização das organizações e serviços e a participação direta dos cidadãos/clientes/usuários na gestão pública;

"A melhoria da eficiência exigirá também a descentralização dos serviços, aproximando-os da sociedade e do cidadão, retirando do Estado atividades que possam ser mais bem executadas por entidades públicas apoiadas pelo Estado. Também será indispensável redefinir os mecanismos de controle convencionais, voltados para o controle de processos, burocratizado e ineficaz, redirecionando-os para a avaliação de resultados" (BRASIL 1997. Cademos MARE da reforma do estado; c.6, p.7).

"O Projeto das Organizações Sociais tem como objetivo permitir a descentralização de atividades no setor de prestação de serviços não-exclusivos, nos quais não existe o exercicio do poder de Estado, a partir do pressuposto que esses senviços serão mais eficientemente realizados se, mantendo o financiamento do Estado, forem executados pelo setor público não-estatal (...)" (BRASIL 1998. Cadernos MARE da reforma do estado; c.2, p.21).

"(...) ficava claro que se tomava necessário adotar novas formas de gestão da coisa pública, mais compativeis com os avanços tecnológicos, mais ágeis, descentralizadas, mais voltadas para o controle de resultados do que o controle de procedimentos. $E$ também mais compativeis com o avanço da democracia em todo o mundo, que cada vez mais exige uma participação mais direta da sociedade na gestão pública" (BRESSER PEREIRA 1997. Cadernos MARE da reforma do estado; c.1, p.41).

"A Qualidade tem no processo o seu centro prático de ação e compreende a definição clara dos clientes - usuários do serviço público - e dos resultados esperados; a geração dos indicadores de desempenho; a preocupação constante com o fazer certo o que é certo da primeira vez, envolvendo todos os servidores com - compromisso de satisfazer o usuário do serviço público" (BRASIL 1997. Cadernos MARE da reforma do estado; c.4, p.15).

Aos poucos se foram delineando os contornos da nova administração pública em contraposição à administração burocrática, sendo assim expressados seus fundamentos:

"(1) descentralização, do ponto de vista politico, transferindo recursos e atribuições para os niveis políticos regionais e locais; (2) descentralização administrativa, através da delegação de autoridade para os administradores públicos transformados em 
gerentes crescentemente autônomos; (3) organizações com poucos niveis hierárquicos ao invés de estruturas piramidais; (4) organizações flexiveis ao invés de unitárias e monoliticas, nas quais as idéias de multiplicidade, de competição administrada e de conflito tenham lugar; (5) pressuposto da confiança limitada e não da desconfiança total; (6) controle por resultados, a posteriori, ao invés do controle rigido, passo a passo, dos processos administrativos e (7) administração voltada para o atendimento do cidadão, ao invés de auto-referida. Mais amplamente, a administração pública gerencial está baseada em uma concepção de Estado e de sociedade democrática e plural, enquanto que a administração pública burocrática tem um vezo". centralizador e autoritário" (BRASIL 1997. Cadernos MARE da reforma do estado; c.3, p.12).

É importante destacar que no documento com as propostas para o setor saúde pouca ênfase é dada à eficiência sendo, até mesmo, parcimoniosa a utilização do termo e seus correlatos. No entanto, partindo do pressuposto da escassez de recursos, é claramente explicitado no objetivo da reforma administrativa do sistema de saúde a mesma correlação entre cidadania/custos(eficiência)/qualidade "objetivo da reforma é garantir um melhor atendimento ao cidadão através de um controle mais adequado do sistema, que garanta menores custos e melhor qualidade dos serviços pagos pelo Estado." (BRASIL 1997. Cadernos MARE da reforma do estado; c.13. p.11). Como podemos perceber o conceito de eficiência seria imanente na proposta de reforma do Estado, nos anos 90.

No entanto, parece não ter sido suficiente toda ênfase dada ao conceito de eficiência nas propostas, mensagens ao Congresso, textos de divulgação do ideário da reforma. Foi necessário inscrevê-la na Constituição Federal. Com a promulgação da Emenda Constitucional n¹9, em 04 de julho de 1998, a eficiência foi elevada às alturas de um novo princípio constitucional, 
passando a figurar ao lado dos outros quatro tradicionais: a legalidade, a impessoalidade, a moralidade e a publicidade;

"A administração pública direta e indireta, de qualquer dos Poderes da União, dos Estados, do Distrito Federal e dos Municipios obedecerá aos principios de legalidade, impessoalidade, moralidade, publicidade e eficiência e, também, ao seguinte (...)" (BRASIL Constituição Federal, art. $3^{\circ}$ alterando o caput do art. 37, 04 de julho de 1998).

\subsection{HOSPITAL DAS CLÍNICAS DA UFMG: MUDANÇAS ORGANIZACIONAIS E GERENCIAIS PARA A EFICIÊNCIA}

\subsubsection{Análise das Categorias Significativas dos Seminários e Planos Diretores do HC/UFMG de 1992 a 2000}

Para entendermos melhor as mudanças organizacionais e gerenciais ocorridas no $\mathrm{HC}$ na década de 90 e a forma como o conceito de eficiência aparece nos documentos analisados é necessário conhecermos um pouco da história do $\mathrm{HC}^{22}$.

O ensino médico no Brasil, desde sua instalação, valeu-se dos recursos das Santas Casas ou de instituições similares para o indispensável estágio clínico, ocupando professores e alunos suas dependências e responsabilizando-se total ou parcialmente pela assistência aos pacientes. A partir dos anos 40 , as necessidades de ensino e de assistência mais sistematizados, além das iniciativas de pesquisas clínicas, passaram a exigir do cotidiano da assistência uma organização mais adequada. Foram criados

\footnotetext{
${ }^{22}$ Esta retrospectiva histórica da organização do HC é um compilado do artigo de José Mauricio Lemos de Carvalho, escrito no livro comemorativo dos 70 anos da Faculdade de Medicina de 1991 e do documento "Linhas básicas da proposta de novo modelo assistencial para o Hospital das Clinicas", 1992.
} 
os primeiros Hospitais de Ensino no Brasil, estruturados como extensão das cátedras acadêmicas. Na criação da Faculdade de Medicina da UFMG, no discurso do paraninfo da faculdade, professor Miguel Couto, estava latente a idéia de ser necessário um hospital para o bom exercício e aprendizagem da prática médica;

"(...) um instituto desta ordem é uma casa de ensino e de trabalho, segundo a fórmula - ensinar trabalhando, no laboratório e no hospital, ou, melhor, no laboratório, dentro do hospital, para que o estudante, desde o momento em que lhe acudiu a idéia de exercer a medicina, se compenetre de que a nossa arte está toda na obsenação" (Campos 1961:57).

O Hospital das Clínicas da UFMG nasceu em 1928, a partir do agrupamento de algumas clinicas da Faculdade de Medicina (FM), como a de oftalmologia (Hospital São Geraldo), a de cirurgia e oncologia (Hospital Borges da Costa) e a de clínica médica e pediátrica (Hospital São Vicente de Paula pertencente a uma ordem religiosa). Em 1928 iniciou a construção do prédio Central do Hospital das Clínicas, onde se localizava o Hospital São Vicente de Paula, cujo projeto previa a construção de 3 blocos. O último bloco somente foi construido em 1987. Até 1976, o HC era subordinado hierarquicamente à Faculdade de Medicina, sendo administrado em função do ensino. Não havia também um modelo assistencial unificado. Cada clínica era uma extensão dos departamentos de ensino da FM, adotando-se o "critério assistencial" que fosse mais conveniente às suas necessidades docentes. A assistência era, nitidamente, um subproduto do ensino. A atividade ambulatorial tinha como objetivo mais freqüente a identificação de pacientes para serem internados, por motivos que correspondiam às necessidades de um programa de ensino ou pesquisa. Uma 
superintendência administrativa, indicada pela Congregação da Faculdade de Medicina, respondia pelas atividades-meio do hospital, com o auxílio do Departamento de Enfermagem, na gerência dos recursos humanos não médicos ou docentes, ligados à assistência, particularmente o corpo de enfermagem, os assistentes sociais e os nutricionistas.

A submissão da assistência ao ensino, em cátedras, orientou a organização do $\mathrm{HC}$ até os anos de 1973-1974, quando teve início na Faculdade de Medicina o processo de reforma curricular, cuja implantação exigia um novo suporte hospitalar e ambulatorial. Em decorrência desta reforma curricular, o HC tornou-se instituição administrativamente independente da Faculdade de Medicina, com seu regulamento aprovado pelo Conselho Administrativo do HC em 1976. No entanto, é interessante observar que a autonomia do HC somente foi oficializada, dentro da estrutura da Universidade, dez anos depois, em 1986, quando da aprovação do novo Estatuto da UFMG, que definiu o Hospital das Clínicas como um órgão Suplementar ligado diretamente à Reitoria.

Com a autonomia, instalou-se um processo de reforma administrativa, que culminou com a adoção do "Sistema de Cuidado Progressivo ao Paciente"23, uma proposta originaria da Organização Pan-americana de Saúde (OPAS).

\footnotetext{
${ }^{23}$ É um sistema de organização hospitalar por intensidade de cuidados, no qual a Unidade Ambulatorial seria responsável pela prestação de serviços de saúde passiveis de atenção em regime externo (estando apta a atender a 95\% da demanda de atenção médica); a Unidade de Cuidado Básico, responsável pela organização e prestação do atendimento adequado aos pacientes hospitalizados em condiçōes de cronicidade e convalescença; a Unidade de Cuidado Intermediário concentraria a execução de todas as atividades necessárias aos pacientes agudos e graves hospitalizados e uma Unidade de Cuidado Intensivo responsável pelas atividades necessárias à recuperaçăo de pacientes graves com risco de vida imediato. Cada unidade teria uma chefia e contaria com equipe interdisciplinar
} 
O modelo, tal qual foi concebido, teve existência efêmera e, em poucos meses, começou a sofrer modificações formais e informais.

Em 1981, foi firmado o convênio entre o Ministério da Educação e o Ministério da Previdência e Assistência Social para prestação de serviços médicos, pelos hospitais universitários, com financiamento global. Diante do enfraquecimento do "Sistema de Cuidado Progressivo ao Paciente", e da implantação do convênio MEC-MPAS, as administrações que se sucederam procuraram gerenciar adaptações e aprimoramentos assistenciais e administrativos, introduzindo-se importantes modificaçōes no Regulamento do Hospital das Clínicas.

Em 1990 foi instituída uma comissão para propor um novo modelo para o $\mathrm{HC}$ devido à ausência de definição de um modelo assistencial. Além disto, o HC apresentava produção muito abaixo de sua capacidade; distanciamento em relação às demais agências e instâncias que compunham o sistema de atenção à saúde e um regime definido pelas atividades escolares (praticamente parava nos meses de férias). Partindo deste diagnóstico, foi elaborado o documento "Linhas básicas da proposta de novo modelo assistencial para o Hospital das Clínicas". Esta proposta visava: a integração das atividades clínicas ambulatoriais e hospitalares; a introdução do gerenciamento das atividades fim e atividades meio do Hospital; o incentivo ao desenvolvimento das atividades ambulatoriais, tanto clínicas quanto cirúrgicas; a adoção de um plano de metas quantitativas e qualitativas em cada unidade de produção, de acordo com os objetivos gerais do hospital; 
criação das Diretorias de Divisão; adequação das demandas assistenciais ao ensino e à pesquisa; instituição da remuneração baseada na produtividade; busca de parceiros financeiros no Município e no Estado; adequação dos currículos das Unidades de Ensino, que utilizavam o $\mathrm{HC}$, ao novo modelo proposto. Este documento foi o norteador das discussões e das propostas retiradas no "I Seminário ${ }^{24}$ do HC", em 1992, cuja sistematização por categoria está apresentada na Tabela. 5. Os Planos Diretores de 1994 e 1995 e do biênio 1996-98 refletiam as discussões, propostas e o variado grau de implementação das diretrizes retiradas no I Seminário.

O objetivo da proposta de reorganização do $H C$ foi a descentralização da estrutura de tomada de decisões. O organograma especificava as divisões clínicas (médica, cirúrgica, perinatal, pediatria, emergência) e os setores de apoio propedêutico e terapêutico, que deviam estar ligados à diretoria clínica. Cada divisão clínica possuia uma diretoria de divisão, composta por uma coordenadoria médica, coordenadoria de enfermagem e coordenadoria administrativa. Ligados à diretoria administrativa, estavam as divisões administrativas de recursos humanos, financeira e de infraestrutura. $O$ modelo passou a considerar duas grandes forças na instituição - a técnica e a administrativa. Nessa proposta, a função do Conselho Administrativo era de definição das linhas básicas de atuação do HC. A composição sugerida foi: diretores das unidades de ensino que atuam no $\mathrm{HC}$, diretor geral, diretor

\section{centralizadas.}

${ }^{24}$ O I Seminário foi realizado em duas etapas, sendo que a segunda ficou conhecida como II Seminário, apesar de apenas dar continuidade à discussão anterior, por isso o analisamos como único. 
clínico e diretor administrativo. Tal composição visava a agilidade da instituição (FIG. 1).

No documento "Linhas Básicas", apresentou-se o HC como uma instituição com a responsabilidade de formar recursos humanos para o setor saúde, de produção e divulgação do conhecimento e incorporação crítica das tecnologias. As atividades de ensino deviam concentrar-se na formação de profissionais adequados à realidade de saúde do estado e do pais, o que tornava indispensável a integração com outros serviços. A definição básica da política de atuação do HC seria ditada pela demanda assistencial. O HC passou a ter seu plano de metas e deixou de subordinar-se às demandas de ensino. A demanda assistencial e de ensino devia se adequar mutuamente, sob a coordenação do Conselho Técnico-Científico. 
TABELA 5: Síntese das categorias analisadas no relatório final do I Seminário do Hospital das Clínicas/UFMG, Belo Horizonte, 1992

\begin{tabular}{|c|c|c|c|c|c|c|c|}
\hline \multicolumn{8}{|c|}{$\begin{array}{l}\text { Imagem Objetivo: Organizaçăo capaz de gerar e gerir os meios que lhe săo indispensáveis para o cumprimento de suas atribuiç̧es assistenciais, docentes e de pesquisa, com elevada } \\
\text { efetividade e eficiencia, atendendo as necessidades surgidas dos padrós nosologicos identificados e da avaliaçăo da capacidade de resposta dos serviços existentes }\end{array}$} \\
\hline $\begin{array}{l}\text { Organizaçăo e } \\
\text { Estrutura }\end{array}$ & $\begin{array}{l}\text { Modelo Assistencial } \\
\text { Pedagógico }\end{array}$ & Gestăo & Público & Financlamento & $\begin{array}{l}\text { Relaçōes } \\
\text { Institucionais }\end{array}$ & Relaçðes de Trabalho & Eficiência \\
\hline $\begin{array}{l}\text { - Integraçáo das } \\
\text { unidades } \\
\text { ambulatorial e } \\
\text { hospitalar } \\
\text { - Criaçăo das } \\
\text { Divisøes Cllnicas e } \\
\text { Divisøes } \\
\text { Administrativas } \\
\text { compostas por } \\
\text { unidades de } \\
\text { produçâo } \\
\text { descentralizadas e } \\
\text { com automonia de } \\
\text { gestăo, agrupadas } \\
\text { de acordo com sua } \\
\text { afinidade tecnico- } \\
\text { operacional, } \\
\text { - Estrutura } \\
\text { verticalizada. }\end{array}$ & $\begin{array}{l}\text { - Indissociabilidade } \\
\text { entre ensino, pesquisa } \\
\text { e assistencia } \\
\text { - Formaçăo de } \\
\text { profissionais } \\
\text { adequados à realidade } \\
\text { de saúde do estado e } \\
\text { do pals. } \\
\text { - Subordinaçăo do } \\
\text { ensino à assistencia }\end{array}$ & $\begin{array}{l}\text { - Politica } \\
\text { gerencial deve } \\
\text { obedecer aos } \\
\text { critérios de } \\
\text { delegaçáo de } \\
\text { competencia, } \\
\text { descentralizaçăo, } \\
\text { gerencia } \\
\text { participativa, maior } \\
\text { entrosamento entre } \\
\text { as áreas, respeito à } \\
\text { competencia } \\
\text { técnica de cada } \\
\text { um, maior } \\
\text { autonomia da } \\
\text { chefia dos setores } \\
\text { e que deve estar de } \\
\text { acordo com as } \\
\text { prioridades do } \\
\text { modelo } \\
\text { assistencial. }\end{array}$ & $\begin{array}{l}\text { - Necessidade } \\
\text { de inserçăo no } \\
\text { sistema de saúde } \\
\text { - Caráter público } \\
\text { nâo seria somente } \\
\text { devido às } \\
\text { alteraçరes geradas } \\
\text { pelo governo } \\
\text { federal } \\
\text { (desfinanciamento), } \\
\text { mas, tambem, pelo } \\
\text { modelo } \\
\text { organizacional } \\
\text { adotado pelo } \\
\text { hospital; } \\
\text { - E defendida a } \\
\text { representaçăo } \\
\text { popular nos orgăos } \\
\text { de deliberaçăo. }\end{array}$ & $\begin{array}{l}\text { - Grande } \\
\text { dependencia do } \\
\text { governo federal } \\
\text { (MEC, INAMPS, MS); } \\
\text { - Expectativa de } \\
\text { financiamento } \\
\text { baseado no } \\
\text { orçamento; } \\
\text { - Politica de } \\
\text { ampliaçáa das } \\
\text { receitas: aumento da } \\
\text { produçăo de serviços } \\
\text { para o SUS. } \\
\text { - Alternativas } \\
\text { externas } \\
\text { consideradas: } \\
\text { aumento do número } \\
\text { de atendimento a } \\
\text { convenios e } \\
\text { particulares. }\end{array}$ & $\begin{array}{l}\text { Muito voltado } \\
\text { para a necessidade } \\
\text { de reestruturaçấo } \\
\text { interna } \\
\text { - Distanciamento } \\
\text { do HC em relaçấo às } \\
\text { demais agencias e } \\
\text { instâncias do SUS } \\
\text { Principal } \\
\text { interlocutor externo é } \\
\text { o governo federal } \\
\text { - Participaçấo } \\
\text { paritária das unidades } \\
\text { que atuam no HC nos } \\
\text { órgăos de deliberaçáo }\end{array}$ & $\begin{array}{l}\text { - Elemento } \\
\text { estrategico do modelo } \\
\text { assistencial/organizaci } \\
\text { onal } \\
\text { polftica perta de uma } \\
\text { ponte } \\
\text { de desenvolvimento } \\
\text { de RH, extensiva a } \\
\text { todos os setores e } \\
\text { unidades e a todas as } \\
\text { categorias } \\
\text { profissionais } \\
\text { - O incentivo a } \\
\text { produçâo deve ser } \\
\text { para todas as } \\
\text { categorias } \\
\text { profissionais } \\
\text { As contrataçces } \\
\text { devem ser } \\
\text { exclusivamente por } \\
\text { concurso público, com } \\
\text { salário digno e } \\
\text { mesma jornada de } \\
\text { trabalho. }\end{array}$ & $\begin{array}{l}\text { - Relaçăo } \\
\text { adequada entre o } \\
\text { esforço que a } \\
\text { sociedade dispensa } \\
\text { para criar, operar e } \\
\text { manter a instituiçăo e } \\
\text { o retorno que lhe é } \\
\text { proporcionado. } \\
\text { Otimizaçăo dos } \\
\text { recursos disponiveis } \\
\text { - Premissa do } \\
\text { modelo de gestấo do } \\
\text { HC, para que se atinja } \\
\text { a imagem/objetivo. }\end{array}$ \\
\hline
\end{tabular}

Fonte: "Linhas básicas da proposta de novo modelo assistencial para o Hospital das Clínicas", 1992 e Relatório Final do I Seminário do Hospital das Clinicas. 
FIGURA 1 Organograma, 1992

Hospital das Clínicas da UFMG

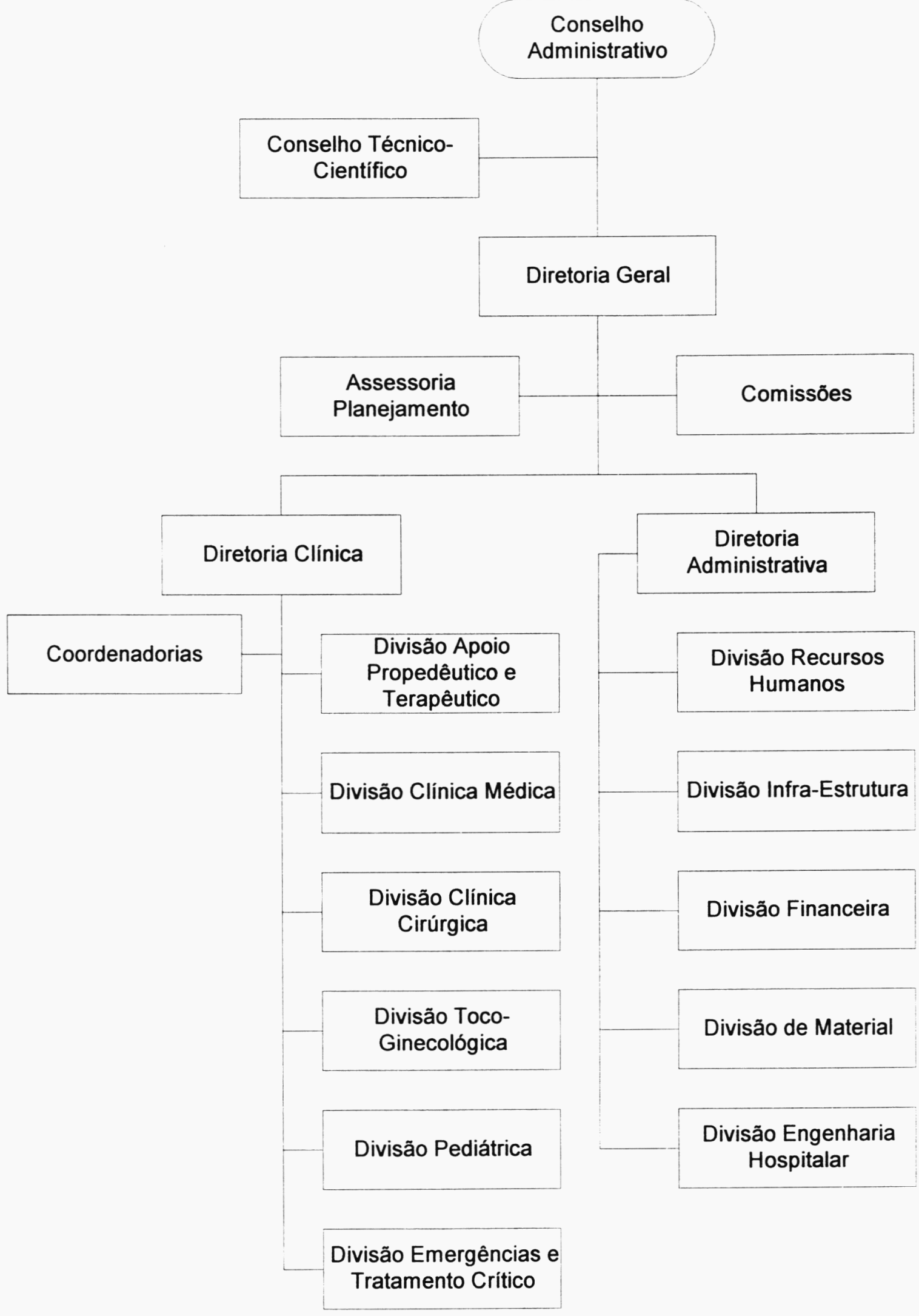


Para a elaboração da política gerencial, deveriam ser considerados os critérios de delegação de competência, descentralização, gerência participativa, autonomia da chefia dos setores, maior entrosamento entre as áreas, respeito à competência técnica e estar de acordo com as prioridades do modelo assistencial. Assim, seria necessário o estabelecimento de autonomia para as unidades de produção, que deveriam ser configuradas como unidades assistenciais de planejamento, orçamento e gerenciamento. A estrutura interna das divisōes assistenciais deveria contar com uma chefia única e subchefias de enfermagem, médica e administrativas, que seriam as responsáveis pela gerência de todas as atividades das unidades assistenciais (unidades de internação e unidades ambulatoriais) a ela subordinadas. Seriam instrumentos orientadores utilizados para a gestão: a) plano de metas quantitativas e qualitativas para cada unidade de produção, de acordo com os objetivos gerais do hospital; b) introdução de instrumentos de avaliação, tais como auditoria técnica e administrativa, para controle do processo assistencial. Destacava-se o movimento de descentralização como forma de se obter uma melhor gerência, melhor competência e eficiência, com vistas aos objetivos do hospital, e todas as ações para sua implantação deveriam ser direcionadas nesse sentido.

O questionamento mais importante sobre o modelo organizacional e gerencial proposto, era se ele atenderia ao direito de cidadania. O papel social do HC deveria ser de assistência, inserido no SUS, com financiamento da União e, com representação popular nos órgãos de deliberação, portanto garantindo o caráter democrático e participativo. $\mathrm{O}$ atendimento a cliente 
particular deveria ser desvinculado do lucro e os recursos provenientes seriam apenas uma forma de garantir a condição de excelência na assistência ao paciente do SUS.

A proposta apresentada continha um estudo econômico financeiro sobre o HC, com a evolução de receitas e despesas. Naquela apresentação, constatou-se que os recursos do tesouro, que em 1983 representavam $49 \%$ dos recursos globais, constituindo-se como principal fonte de financiamento, não evoluiram no periodo, o que refletia a politica do governo federal de não ampliar a destinação de verbas aos hospitais universitários. O crescimento da receita foi sustentado pela arrecadação própria, cuja participação na receita total elevou-se de $19 \%$ em 1983 para 92\% em 1989. Essa expansão significativa das receitas próprias poderia ser em parte explicada por mudanças na política de remuneração do Instituto Nacional de Assistência Médica e Previdência Social (INAMPS), pela classificação do HC como centro de excelência e por aplicações financeiras de saldos de caixa de convênios.

Outra questão apresentada no estudo foi o destaque de que a política de preços do governo para o setor saúde tinha sido perversa e insustentável. $O$ governo introduzira novos critérios de remuneração, indicando que o HC perderia $30 \%$ ou mais de sua receita, inviabilizando seu funcionamento. Diante desse quadro, esforços deveriam ser feitos para colocar em prática uma politica mais agressiva de ampliação das receitas do $\mathrm{HC}$, rumo à sua auto-suficiência, através da diversificação das fontes de financiamento das atividades assistenciais e da busca de novas receitas, reduzindo a excessiva 
dependência em relação ao INAMPS. Ao discutir a proposta de financiamento apresentada, destacou-se o receio de que financiamentos alternativos pudessem trazer injustiças sociais para dentro da instituição. A conclusão final da plenária sobre as fontes financiadoras do $\mathrm{HC}$ foi de que o financiamento deveria ser feito por órgãos públicos e gerenciado pelo conselho administrativo.

Nas discussões apresentadas no relatório final do Seminário defendeu-se que o modelo assistencial fosse democrático, social, participativo e que a qualidade da prestação da assistência deveria ser supervisionada, uma vez que era a qualidade da assistência que garantia a qualidade do ensino.

Foi destacado no documento, o distanciamento do $\mathrm{HC}$ em relação ao sistema de atenção à saúde, ocorrendo um certo descompromisso com o quadro sanitário prevalente. Na construção do novo modelo, o HC deveria estar integrado ao sistema público de atenção à saúde, e adaptar-se às suas necessidades e exigências. No entanto, deveria preservar sua autonomia administrativa e com os compromissos sociais na assistência, no ensino e na pesquisa. Ao apresentar as discussões sobre essas questões, foi reforçada a necessidade de abertura do HC para o ambiente externo. Sobre as relações com a sociedade, defendeu-se a representação popular nos órgãos de deliberação. Não houve qualquer menção sobre a relação com os sindicatos.

No documento "Linhas Básicas da Proposta", foram feitas apenas duas referências sobre relações de trabalho. A primeira foi o estudo de formas de remuneração para os profissionais que estimulassem o aumento da 
produtividade, sem sacrifico da qualidade. A segunda, considerada como elemento estratégico do modelo assistencial proposto, foi a adoção de uma politica permanente de desenvolvimento de $\mathrm{RH}$, extensiva a todos os setores e unidades e a todas as categorias profissionais. Nos relatórios do I Seminário, as discussões sobre as relações de trabalho passavam por três eixos principais: corporativismo (médico), jornada de 6 horas para funcionários e defesa do concurso público. Tanto a política de recursos humanos, como o RJU, segundo a discussão, deveriam ser flexiveis. O RJU foi considerado uma camisa de força, caso a propalada autonomia universitária fosse implementada.

No I Seminário discutiu-se que a suposta ineficiência dos órgãos públicos vinha sendo utilizada como razão para inviabilizar a universidade e os hospitais públicos, favorecendo os interesses privados. Em adição, a defasagem entre custo e custeio dos hospitais universitários trazia dificuldades para o cumprimento dos objetivos de ensino, pesquisa e formação de recursos humanos. Internamente, considerou-se que a ausência de uma definição do modelo assistencial e organizacional estava contribuindo para a baixa eficiência social do $\mathrm{HC}$, entendida como a relação inadequada entre o esforço que a sociedade dispensa para criar, operar e manter a instituição e o retorno que lhe é proporcionado. Foi considerado como premissa para a construção do modelo de gestão que o HC deveria dispensar cuidados de complexidade tecnológica crescente, de forma efetiva, eficaz e eficiente, e universal. $O$ objetivo da descentralização proposta era aumentar a eficiência. Algumas propostas deixavam clara a 
preocupação com otimização dos recursos disponiveis como, por exemplo, a exploração da capacidade ociosa; avaliação sistemática dos recursos, inclusive dos custos da assistência, nos seus aspectos quantitativo e qualitativo; avaliação de desempenho continua para adequação do funcionário ao trabalho; estudo permanente sobre a força de trabalho nos diversos setores, visando a distribuição racional e 0 atendimento das necessidades de serviços; qualificação profissional urgente para adequação à formação e cargo. $O$ profissionalismo e a produtividade eram características que a administração do hospital deveria possuir. $\mathrm{Na}$ conclusão do Seminário foi apresentada a imagem-objetivo de que o "HC se transforme numa organização capaz de gerar e gerir os meios que the são indispensáveis para o cumprimento de suas atribuições assistenciais, docentes e de pesquisa, com elevada efetividade e eficiência, atendendo às necessidades surgidas dos padrões nosológicos identificados e da avaliação da capacidade de resposta dos serviços existentes".

A sistematização das categorias do Plano Diretor de 1994 encontra-se na Tabela. 6. O Hospital das Clínicas continuava a ter sua estrutura administrativo-gerencial mais próxima do modelo acadêmico da Universidade, e sua direção composta basicamente por quadros da própria Universidade. As decisões estariam centralizadas nos diretores: o geral, o clínico e o administrativo com uma estrutura administrativa intermediária extremamente difusa, não sendo propícia à clara identificação dos atores e recursos que participariam do processo produtivo: o planejamento e $\circ$ compromisso com resultados não existiam em termos setoriais. Segundo o 
documento, seria preciso reestruturar $\mathrm{OHC}$ através da formação de Unidades Operativas auto-suficientes em gestão, dentro do processo de descentralização. Foi apresentada a proposta de descentralização administrativo-financeira sob a forma de "kit operacional básico" numa unidade piloto. No entendimento da direção, um hospital deste porte não poderia ser administrado eficientemente apenas pela sua direção central. $O$ papel da direção deveria ser o de negociar metas e avaliar os resultados alcançados, com o mínimo de interferência. As unidades teriam autonomia para gerir os recursos necessários, inclusive $\mathrm{RH}$, para alcançar as metas pactuadas, dentro de um projeto geral delineado pela direção. Aos chefes de Unidades Operativas caberiam maiores responsabilidades na administração de suas atividades e a sua relação com a Diretoria se faria através de relatórios mensais, especialmente no tocante aos resultados, alcançados tanto do ponto de vista financeiro quanto da qualidade; por sua vez a direção do Hospital forneceria o suporte administrativo, sempre que necessário. $O$ financiamento dessas unidades seria feito através da composição de um fundo, constituido de $20 \%$ do volume de produção da unidade, para investimento em materiais, equipamentos, etc.

Sobre o financiamento foram apresentados os problemas relacionados aos freqüentes desequilibrios financeiros - dependência quase exclusiva das receitas do convênio SUS, que oferecia uma tabela de remunerações bastante baixa para a maioria dos procedimentos, além de efetuar 0 pagamento com prazo longo, o que corroia as faturas em função da inflação; ausência de outras fontes de custeio, como convênios, que aumentariam o 
faturamento tanto por terem preços mais convidativos quanto por reduzirem o prazo para recebimento dos serviços prestados. As greves e paralisações somadas ao período de férias escolares seriam responsáveis por $50 \%$ de queda no faturamento do HC. Permanecia ainda a perda de recursos por erros no processamento do faturamento. Propostas apresentadas: ativação de serviços de alto custo, uma vez que promoveriam indiscutivel aumento na arrecadação (ampliação do serviço de hemodiálise, a reativação de um terceiro turno ambulatorial e a ativação do setor de transplante de medula óssea); buscar atingir os $30 \%$ do atendimento permitido para convênios e particulares. Os investimentos em tecnologia e equipamentos de maior porte seriam organizados sob a forma de projetos, para os quais se buscariam recursos de financiamento junto a órgãos federais, estaduais e municipais, bem como em agências internacionais, como o Banco Mundial e o Banco Interamericano de Desenvolvimento.

Nas relações de trabalho foi realizado um diagnóstico de que a ausência de uma política de Recursos Humanos trazia problemas de baixo moral dos servidores e, conseqüentemente, baixa produtividade. Além disto, em função da crônica precariedade financeira em que vivia $\mathrm{HC}$, não existia a perspectiva de ganhos reais de salário, promoções ou treinamento, para os funcionários contratados pela FUNDEP. Com relação aos professores médicos, foi detectada uma relação de trabalho pouco explicitada, em que as suas obrigações se restringiriam às atividades de ensino e de pesquisa, sem o compromisso institucional com a assistência e, conseqüentemente, com as questões de faturamento, de produção e de custos. Por razões 
relacionadas à baixa remuneração e às condições de trabalho em um ambiente sucateado pela escassez de investimentos, muitos dos melhores profissionais estavam transferindo suas atividades assistenciais (não docentes) para hospitais da rede privada. Ações propostas: concurso público para contratação de pessoal, horários diferenciados para atendimento às demandas assistenciais; implantação, em médio prazo, de uma nova arquitetura administrativa para o $\mathrm{HC}$; treinamento em técnicas de gerenciamento; revisão de funções e cargos; análise de base motivacional. 
TABELA 6 - Síntese das categorias analisadas no Plano Diretor do Hospital das Clínicas/UFMG de 1994

\begin{tabular}{|c|c|c|c|c|c|c|}
\hline Organizaçāo/Estrutura & $\begin{array}{c}\text { Modelo } \\
\text { Assistencial } \\
\text { Pedagógico }\end{array}$ & Gestão & Financiamento & $\begin{array}{c}\text { Relações } \\
\text { Institucionais }\end{array}$ & $\begin{array}{c}\text { Relações de } \\
\text { Trabalho }\end{array}$ & Eficiência \\
\hline $\begin{array}{l}\text { Diagnóstico: } \\
\text { organizaçáo mais próxima } \\
\text { do modelo académico, } \\
\text { direçăo composta por } \\
\text { quadros da Universidade; } \\
\text { decisర̃es centralizadas em } \\
\text { três diretores; estrutura } \\
\text { administrativa intermediária } \\
\text { extremamente difusa; não } \\
\text { existe planejamento e } \\
\text { compromisso } \\
\text { resultados. } \\
\text { Propostas: revisão de } \\
\text { estruturas organizacionais, } \\
\text { com ampla revisão dos } \\
\text { processos administrativos, } \\
\text { com o objetivo de obter-se } \\
\text { processos otimizados e } \\
\text { padrões tecnológicos. } \\
\text { - Maior detalhamento do } \\
\text { organograma do HC. }\end{array}$ & $\begin{array}{l}\text { - Na medida em } \\
\text { que as questoes } \\
\text { organizacionais } \\
\text { forem se } \\
\text { resolvendo, o HC } \\
\text { estaria apto a } \\
\text { proporcionar } \\
\text { excelência no } \\
\text { atendimento, } \\
\text { qualidade no } \\
\text { ensino e pesquisa e } \\
\text { possibilidades } \\
\text { concretas de } \\
\text { promover a sua } \\
\text { necessária } \\
\text { atualização } \\
\text { tecnologica. }\end{array}$ & $\begin{array}{l}\text { - Proposta de } \\
\text { descentralização } \\
\text { administrativo- } \\
\text { financeira, sob a } \\
\text { forma de "kit" } \\
\text { operacional básico, } \\
\text { implantado em uma } \\
\text { Unidade Operacional } \\
\text { piloto: } \\
\text { descentralização de } \\
\text { responsabilidades e } \\
\text { recursos; metas e } \\
\text { resultados pactuados } \\
\text { com a diretoria. }\end{array}$ & $\begin{array}{l}\text { - Diagnóstico: } \\
\text { desequilibrios } \\
\text { financeiros - } \\
\text { dependência quase } \\
\text { exclusiva do SUS, } \\
\text { greves e férias } \\
\text { escolares são } \\
\text { responsáveis por } 50 \% \\
\text { de queda no } \\
\text { faturamento; erros } \\
\text { nos processos de } \\
\text { faturamento } \\
\text { Propostas: } \\
\text { ativaçăo de serviços } \\
\text { de alto custo; } \\
\text { reativaçăo do terceiro } \\
\text { turno ambulatorial; } \\
\text { maior abertura aos } \\
\text { convênios com planos } \\
\text { de saúde. }\end{array}$ & $\begin{array}{l}\text { - Buscar junto } \\
\text { às Unidades } \\
\text { Académicas que } \\
\text { utilizam o } \\
\text { hospital, } \\
\text { alternativas de } \\
\text { não interrupçăo } \\
\text { do } \\
\text { funcionamento } \\
\text { do hospital no } \\
\text { perlodo de férias. }\end{array}$ & $\begin{array}{l}\text { - Diagnóstico: } \\
\text { desmotivaçăo do } \\
\text { pessoal, baixa } \\
\text { produtividade; } \\
\text { inserçăo do } \\
\text { professor-médico năo } \\
\text { é remunerada. } \\
\text { - Propostas: } \\
\text { politicas de } \\
\text { capacitaçăo como } \\
\text { forma de valorizaçăo } \\
\text { e crescimento } \\
\text { profissional; } \\
\text { necessidade de } \\
\text { planejar e buscar } \\
\text { formas de } \\
\text { remuneraçăo } \\
\text { compativeis com o } \\
\text { mercado para todos } \\
\text { os profissionais. }\end{array}$ & $\begin{array}{l}\text { - O objetivo central da } \\
\text { proposta de } \\
\text { descentralização é a } \\
\text { administraçăo eficiente de } \\
\text { um hospital de grande } \\
\text { porte; } \\
\text { - A estrutura de } \\
\text { unidades operativas tem } \\
\text { dois objetivos primordiais: } \\
\text { o de iniciar o processo de } \\
\text { descentralizaçăo de } \\
\text { decisáo e recursos; e o de } \\
\text { incentivar maior volume } \\
\text { de produção (opera com } \\
\text { grande capacidade } \\
\text { ociosa). }\end{array}$ \\
\hline
\end{tabular}


A sistematização das categorias do Plano Diretor de 1995 encontra-se na Tabela 7. O Plano de 1995 diagnosticava, novamente, a inconsistência da estrutura organizacional; a desarticulação entre departamentos e setores do Hospital; linha de autoridade difusa (relação diretoria-profissionais professores); inadequação da estrutura de poder (departamento de ensino, conselho administrativo). Segundo o documento, qualquer projeto de reorganização do $\mathrm{HC}$ teria que se subjugar à sua missão e meta de sobrevivência - otimização da relação capacidade instalada/receita/custos. A missão definida foi: "buscar sempre a excelência no atendimento aos agravos da saúde da população, prestando cuidados assistenciais à clientela universalizada e formar recursos humanos, desenvolvendo e incorporando criticamente novas tecnologias".

O diagnóstico de que o sistema de gestão seria dissociado das metas persistiu assinalando o caráter excessivamente centralizado (clínicas sem poder, sem responsabilidades, sem metas), sem planejamento e controle. $\mathrm{Na}$ proposta de gerenciamento constava o objetivo de compatibilizar as diretrizes com as metas, de tal forma que as políticas e estruturas organizacionais e operacionais, os investimentos e os gastos, ou seja, a utilização dos recursos deveria ser priorizada em função do alcance das metas. De acordo com a avaliação do projeto piloto como bem sucedido, foi proposta a implantação do sistema de Unidades Operativas ("kit gerencial"), em todas as clínicas do HC. Além disto, seriam reforçadas algumas ações como: construção de um sistema de informações gerenciais para tomada de 
decisões; implantação de sistema de medição e avaliação de desempenho de cada setor.

No Plano Diretor de 1995 constatou-se a persistência dos desequilibrios financeiros e problemas de faturamento. Foi novamente proposto o aumento das receitas através da implantação de convênios, política de perenização (regularização do nivel das atividades assistenciais durante o ano) e eliminação de procedimentos não faturados e glosas do SUS. Também, foi proposta a busca da participação do $\mathrm{HC}$ na matriz de distribuição de recursos da Reitoria, para cobertura dos custos relativos às atividades assistenciais.

Apontou-se a continuidade da desmotivação do pessoal, baixa produtividade e inserção do professor-médico em bases não remuneradas. A experiência com a implantação do projeto piloto de Unidades Operativas, levou à conclusão de que seria fundamental que as chefias das UO tivessem autoridade para administrar os recursos humanos responsáveis pela atividade-fim e pela atividade meio. Foi destacada a necessidade de adotarem-se políticas motivacionais (treinamento e capacitação) e de remuneração compativel com o mercado de trabalho. 
TABELA 7 - Síntese das categorias analisadas no Plano Diretor do Hospital das Clínicas/UFMG de 1995

\begin{tabular}{|c|c|c|c|c|c|c|}
\hline $\begin{array}{c}\text { Organização e } \\
\text { Estrutura }\end{array}$ & $\begin{array}{c}\text { Modelo } \\
\text { Assistencial } \\
\text { Pedagógico }\end{array}$ & Gestão & Financiamento & $\begin{array}{c}\text { Relaçōes } \\
\text { Institucionais }\end{array}$ & $\begin{array}{c}\text { Relaçōes de } \\
\text { Trabalho }\end{array}$ & Eficiência \\
\hline $\begin{array}{l}\text { - Diagnóstico: } \\
\text { estrutura } \\
\text { organizacional } \\
\text { inconsistente; } \\
\text { departamentos e } \\
\text { orgåos năo articulados, } \\
\text { linha de autoridade } \\
\text { difusa; estrutura de } \\
\text { poder inadequada } \\
\text { (departamento de } \\
\text { ensino, conselho } \\
\text { administrativo) } \\
\text { - Proposta: partindo } \\
\text { da avaliaçăo positiva } \\
\text { do projeto piloto de } \\
\text { descentralização } \\
\text { (Unidade Operativa), a } \\
\text { utilização de todos os } \\
\text { recursos será para o } \\
\text { alcance das metas. }\end{array}$ & $\begin{array}{l}\text { - Buscar a } \\
\text { excelência na } \\
\text { prestação de } \\
\text { cuidados } \\
\text { assistenciais a } \\
\text { clientela } \\
\text { universalizada; } \\
\text { formar recursos } \\
\text { humanos, } \\
\text { desenvolvendo e } \\
\text { incorporando } \\
\text { criticamente novas } \\
\text { tecnologias, tendo } \\
\text { como metas } \\
\text { alcançar a } \\
\text { excelência no } \\
\text { ensino e pesquisa e } \\
\text { nas atividades } \\
\text { assistenciais. }\end{array}$ & $\begin{array}{l}\text { - Diagnóstico: } \\
\text { sistema de gestăo } \\
\text { dissociado das metas; } \\
\text { centralizaçåo } \\
\text { excessiva (clínicas } \\
\text { sem poder, sem } \\
\text { responsabilidades, } \\
\text { sem metas); ausência } \\
\text { de planejamento e } \\
\text { controle; } \\
\text { implantaçâao das } \\
\text { implas: } \\
\text { Unidades Operativas } \\
\text { em todas as clínicas, } \\
\text { orientadas pelas } \\
\text { metas contidas na } \\
\text { missăo e na meta de } \\
\text { sobrevivência do HC. }\end{array}$ & $\begin{array}{l}\text { - Diagnóstico: } \\
\text { desequilibrios } \\
\text { financeiros, problemas } \\
\text { de faturamento; } \\
\text { - Propostas: } \\
\text { aumento das receitas } \\
\text { através da } \\
\text { implantaçăo de } \\
\text { convenios, política de } \\
\text { perenizaçăo das } \\
\text { atividades } \\
\text { assistenciais durante o } \\
\text { ano; eliminaçăo de } \\
\text { procedimentos năo } \\
\text { faturados e glosas do } \\
\text { SUS; buscar a } \\
\text { participaçăo do HC na } \\
\text { matriz de distribuiçăo } \\
\text { de recursos da } \\
\text { Reitoria. }\end{array}$ & $\begin{array}{l}\text { Proposta de obter } \\
\text { da direçăo da UFMG } \\
\text { um calendário } \\
\text { adequado às } \\
\text { atividades } \\
\text { assistenciais; } \\
\text { - Buscar } \\
\text { participaçăo na matriz } \\
\text { de distribuiçăo de } \\
\text { recursos da reitoria. }\end{array}$ & $\begin{array}{l}\text { - Diagnóstico: } \\
\text { ausência de política } \\
\text { adequada de RH } \\
\text { trazendo problemas de } \\
\text { baixo moral dos } \\
\text { servidores e, de baixa } \\
\text { produtividade; } \\
\text { - Propostas: concurso } \\
\text { público para contrataçăo } \\
\text { de pessoal; horários } \\
\text { diferenciados para } \\
\text { atendimento às } \\
\text { demandas assistenciais; } \\
\text { treinamento em técnicas } \\
\text { de gerenciamento; } \\
\text { revisáo de funçठ̌es e } \\
\text { cargos. }\end{array}$ & $\begin{array}{l}\text { - A meta de } \\
\text { sobrevivência do } \\
\text { hospital, associada às } \\
\text { metas de realizaçăo da } \\
\text { missão, é otimizar a } \\
\text { relação capacidade } \\
\text { instalada/receita/custos, } \\
\text { ou seja, aumentar o } \\
\text { faturamento (em termos } \\
\text { absolutos e eliminando } \\
\text { perdas), reduzir custos, } \\
\text { diminuir a capacidade } \\
\text { ociosa e eliminar o } \\
\text { desperdicio. }\end{array}$ \\
\hline
\end{tabular}


A sistematização das categorias do Plano Diretor de 1996-98 é apresentada na Tabela 8. Este Plano Diretor trazia uma proposta de reestruturação do $\mathrm{HC}$ tendo como diretrizes institucionais básicas: a integração com o sistema de saúde e a qualificação do hospital como unidade de referência. No nivel organizacional/gerencial propunha a consolidação da autonomia das divisões assistenciais, das divisões administrativas e de suas Unidades de Produção; implantação de técnicas de gerenciamento em todos os setores (Unidades Operacionais); introdução, na cultura e na prática do $\mathrm{HC}$, de instrumentos de avaliação, tais como as Auditorias Técnica e Administrativa. Tinha como metas: elevar a produção e produtividade de seus serviços, recompondo eticamente as condições econômicas, sociais e políticas, realisticamente sustentáveis. As relações de trabalho se assentariam no desenvolvimento dos recursos humanos que assegurassem pleno conhecimento do papel e dos objetivos do HC/UFMG, garantindo o indispensável envolvimento com a busca de qualidade e eficiência, e adoção de uma política de remuneração baseada no excedente de produção e na produtividade. Os propósitos contidos no PD seriam desenvolvidos através de projetos 1) Desenvolvimento de recursos humanos; 2) Desenvolvimento institucional 3) Modernização administrativa; 4) Acompanhamento e avaliação do plano diretor. 


\begin{tabular}{|c|c|c|c|c|c|c|}
\hline $\begin{array}{c}\text { Organização e } \\
\text { Estrutura }\end{array}$ & $\begin{array}{c}\text { Modelo } \\
\text { Assistencial } \\
\text { Pedagógico }\end{array}$ & Gestão & Financiamento & $\begin{array}{c}\text { Relações } \\
\text { Institucionais }\end{array}$ & $\begin{array}{l}\text { Relaçס̄es de } \\
\text { Trabalho }\end{array}$ & Eficlência \\
\hline $\begin{array}{l}\text { - Proposta: } \\
\text { reestruturação do HC } \\
\text { através de mudanças em } \\
\text { seu organograma, } \\
\text { organização e geréncia, } \\
\text { traçar diretrizes para } \\
\text { definiçăo do papel do HC } \\
\text { dentro do sistema de saúde, } \\
\text { assegurando suas } \\
\text { condiçбes de ensino, } \\
\text { pesquisa e de prestaçăo de } \\
\text { serviços de referência; e } \\
\text { projeto especifico de } \\
\text { atualização tecnológica; } \\
\text { Consolidação e } \\
\text { estabelecimento progressivo } \\
\text { da autonomia para as } \\
\text { Divisర̋es Assistenciais e } \\
\text { suas unidades de produção, } \\
\text { consolidando-as, como } \\
\text { unidade de planejamento, } \\
\text { de orçamento e de } \\
\text { gerenciamento setorizados. }\end{array}$ & $\begin{array}{l}\text { - Hospital } \\
\text { universitário e público, } \\
\text { de prestaçăo de } \\
\text { serviços integrados de } \\
\text { saúde, harmonizando } \\
\text { os objetivos } \\
\text { assistenciais, de } \\
\text { Ensino e de Pesquisa. } \\
\text { - Dispensar } \\
\text { atençăo de } \\
\text { complexidade } \\
\text { tecnológica crescente, } \\
\text { de forma eficaz, } \\
\text { eficiente, efetiva e } \\
\text { universal. }\end{array}$ & $\begin{array}{l}\text { - Os objetivos } \\
\text { básicos - Assistência, } \\
\text { Ensino e Pesquisa - } \\
\text { devem integrar-se sob } \\
\text { administraçåo } \\
\text { unificada, dispondo de } \\
\text { sistema permanente de } \\
\text { programaçăo de } \\
\text { atividades, fixaçăo de } \\
\text { metas, avaliaçăo de } \\
\text { custo e de resultado, } \\
\text { procurando aumentar a } \\
\text { produçăo e } \\
\text { produtividade, de } \\
\text { maneira sustentável; } \\
\text { - Implantaçăo de } \\
\text { técnicas de } \\
\text { gerenciamento em } \\
\text { todos os setores e/ou } \\
\text { unidades operacionais; } \\
\text { - Introduçăo, na } \\
\text { cultura e na prática do } \\
\text { HC, de instrumentos de } \\
\text { avaliaçăo, tais como as } \\
\text { auditorias. }\end{array}$ & $\begin{array}{l}\text { - Desenvolver } \\
\text { politica mais } \\
\text { agressiva de } \\
\text { ampliaçăo das } \\
\text { receitas, rumo à sua } \\
\text { auto-suficiéncia, } \\
\text { através da } \\
\text { diversificaçăo das } \\
\text { fontes de } \\
\text { financiamento das } \\
\text { atividades } \\
\text { assistenciais; } \\
\text { Deteç̧ăo de } \\
\text { oportunidades de } \\
\text { financiamento e de } \\
\text { custeio e realizaçăo } \\
\text { de estudos que } \\
\text { viabilizem sua } \\
\text { captaçăo mantendo } \\
\text { coerência com os } \\
\text { principios } \\
\text { institucionais básicos. }\end{array}$ & $\begin{array}{l}\text { - Consolidaçăo } \\
\text { da integraçăo ao } \\
\text { SUS, preservando } \\
\text { a autonomia } \\
\text { administrativa e } \\
\text { financeira, } \\
\text { - Aliar-se às } \\
\text { outras Unidades } \\
\text { da UFMG, e } \\
\text { instituiçós } \\
\text { pública ou privada } \\
\text { da área de saúde } \\
\text { para a formaçăo e } \\
\text { capacitaçăo de } \\
\text { RH em saúde } \\
\text { garantidos } \\
\text { sempre os } \\
\text { critérios de } \\
\text { qualidade e } \\
\text { equidade. }\end{array}$ & $\begin{array}{l}\text { - Desenvolvimento } \\
\text { de seus RH que } \\
\text { assegurem pleno } \\
\text { conhecimento do } \\
\text { papel e dos objetivos } \\
\text { do HC/UFMG, } \\
\text { garantindo o } \\
\text { indispensável } \\
\text { envolvimento com a } \\
\text { busca de qualidade e } \\
\text { eficiencia, que na } \\
\text { Saúde sempre } \\
\text { implicará em } \\
\text { equidade. } \\
\text { - Remuneraçăo } \\
\text { adicional baseada no } \\
\text { excedente de } \\
\text { produçăo e na } \\
\text { produtividade }\end{array}$ & $\begin{array}{l}\text { Organizar-se com o } \\
\text { objetivo de permitir a } \\
\text { melhor utilizaçăo dos } \\
\text { recursos humanos, } \\
\text { materiais e tecnológicos, } \\
\text { adequando seus custos, } \\
\text { como forma de otimizar } \\
\text { seus resultados } \\
\text { académicos e } \\
\text { assistenciais; } \\
\text { Aumento da } \\
\text { produçăo de todos os } \\
\text { serviços, através da } \\
\text { utilizaçăo da capacidade } \\
\text { ociosa, e/ou do aumento } \\
\text { da produtividade, } \\
\text { assegurando a } \\
\text { qualidade dos processos } \\
\text { e resultados. }\end{array}$ \\
\hline
\end{tabular}


O III Seminário do HC foi o fórum privilegiado de discussão das alternativas de adequação da estrutura organizativa e gerencial do $\mathrm{HC}$ a um novo ambiente de profundas mudanças. As sínteses, por categorias, com as propostas deste Seminário são mostradas na Tabela 9 e o organograma na Figura 2. Partiu-se de um diagnóstico mostrando que: (i) durante a última década a utilização de ferramentas gerenciais e de ações políticas de pressão foram determinantes na solução dos problemas estruturais do HC; (ii) o problema gerado pela dependência financeira do governo federal teria evoluido com o tempo, exigindo da instituição maior esforço e competência gerencial; (iii) o processo de tomada de decisão centralizada seria causa do fracasso de planejamentos e projetos, pois não atingiria os níveis operacionais e impondo um longo tempo para implementação de uma decisão; e (iv) que o regimento do $\mathrm{HC}$, oficialmente em vigor, era o primeiro regimento, aprovado em 1976, estando completamente defasado naquele momento.

A proposta apresentada estruturava-se a partir da definição da missão do HC: "desenvolver, eficaz e eficientemente, e de forma equilibrada, a formação e a capacitação de recursos humanos e a pesquisa e a assistência, respondendo às necessidades de saúde da população e, inserido no Sistema de Saúde do Estado de Minas Gerais, constituir-se como referência para áreas especificas". Os princípios gerenciais orientadores desta estrutura proposta foram: descentralização, através da gerência participativa, entendida como co-responsabilidade e autonomia de atuação na otimização dos recursos disponiveis, estruturadas através das 
unidades gestoras; relações horizontais entre as unidades gestoras ${ }^{25}$. É interessante destacar que a proposta da reforma de Estado para os hospitais - a organização social - era vista como terceirização/privatização dos serviços e foi citada apenas uma vez.

No modelo assistencial pedagógico, a assistência de qualidade era compreendida como geradora de ensino de qualidade. A pesquisa era vista como instrumento de qualificação da assistência e do ensino bem como forma de captação de recursos. O HC deveria constituir-se em referência municipal, estadual e federal para procedimentos especializados e de alta complexidade. A assistência primária deveria ser prestada em casos especiais, através de projetos especificos. A atuação do estudante deveria abranger a totalidade da clientela.

A diretriz para o planejamento e para a ação deveria integrar as linhas administrativas, técnica e ensino/pesquisa para a orientação de atividadefim, atividade-meio e normativa, concretizando-se nas unidades gestoras. A unidade gestora teria autonomia de atuação e de gestão de recursos humanos, fisicos, materiais e equipamentos. Os princípios de gestão apresentados foram: avaliação de resultados segundo indicadores de qualidade e produtividade; racionalização de custos, visando a adequação da unidade aos recursos disponiveis; simplificação de niveis de tomada de decisão, descentralização das decisões e responsabilidades. Os objetivos foram: agilidade na tomada de decisão, melhor adequação dos recursos do

${ }^{25}$ Esta proposta está em consonância com o que se denomina "modelos gerenciais alternativos" desenvolvido por CEClLIO et. al (1997) e implantado em alguns hospitais 
trabalho, otimização dos recursos para redução dos deficits, distribuição dos recursos disponiveis.

O diagnóstico sobre o financiamento destacou que o novo modelo econômico e de reforma do estado, agravou a crise nos hospitais universitários. Além disso, a regulamentação dos planos privados de saúde empurrou aos $\mathrm{HU}$ os atendimentos de maior custo e de menor rentabilidade. A política governamental não estaria priorizando o setor saúde, o que, segundo o documento, basicamente explicaria a crise - as verbas seriam escassas, apesar dos argumentos de má gerência apresentados pelo governo federal, esquecendo que o desenvolvimento simultâneo de atividades de assistência, ensino e pesquisa eleva os custos operacionais em relação às instituições puramente assistenciais. O MEC estava assumindo somente $58 \%$ da folha de pessoal (UFMG e residentes). O HC como órgão suplementar da UFMG, recebia verba da reitoria para pagamento de parte dos serviços de vigilância e portaria e pagamento de bolsas para alunos da Fundação Universitária Mendes Pimentel (FUMP). Desta forma, o HC sobrevivia com recursos próprios, provenientes do SUS, de convênios e particulares. A principal fonte era o SUS, através do pagamento de $\mathrm{AlH}$, acrescidas do Fator de Incentivo ao Desenvolvimento do Ensino e da Pesquisa em Saúde (FIDEPS) ${ }^{26}$ além do pagamento de consultas e procedimentos ambulatoriais. Os convênios assinados com a Secretaria Municipal de Saúde (1996) e a Secretaria Estadual de Saúde 
(1997) tornaram possivel manter o atendimento, e pagar grande parte da divida então existente. Em 1998 encerraram-se os convênios citados, que estariam sendo renegociados, mas não poderiam ser considerados como parte integrante da receita em função da irregularidade do pagamento. Mesmo assim, foi discutido que a Secretaria Municipal de Saúde de Belo Horizonte (SMS/BH), dentro do convênio global, teria solicitado ao $\mathrm{HC}$ a oferta de serviços que estariam estrangulados na rede, o que seria viável se, em contrapartida, a SMS/BH ampliasse os tetos dos procedimentos melhor remunerados. A busca de fontes alternativas de financiamento tornou-se questão de sobrevivência. Dentro da perspectiva de autonomia universitária e de acordo com os dados apresentados, o HC teria possibilidade de se tornar viável, cumprindo sua missão. O desafio, então, seria encontrar outras fontes de financiamento capazes de suprir o déficit mensal. Uma série de alternativas foi considerada, como a ocupação de $30 \%$ dos leitos com convênios particulares; expansão da prestação de serviços ao SUS; parceria com corpo clínico, mas tal sugestão foi considerada polêmica, em função da preocupação com o risco de privatização; proposta de plano próprio de assistência, mas acreditava-se ferir as caracteristicas da instituição, porque a população era carente e não teria recurso para tal; adoção de procedimentos internos para aumentar produtividade. A proposta em relação ao setor privado foi a de buscar apoio político e financeiro, sensibilizando-os para a importância social do HC. Com relação ao SUS, defendeu-se que deveria buscar-se tratamento financeiro diferenciado, em razão das

${ }^{26}$ O Fator de Incentivo ao Desenvolvimento do Ensino e da Pesquisa em Saúde - FIDEPS - era um percentual, que variava de $25 \%$ a $75 \%$, em cima do valor de cada AlH paga pelo 
características do atendimento prestado pelo $H C$, de qualidade e não seletividade. Outras propostas de financiamento: (i) projeto junto ao BNDES, de interesse social e vinculado a projeto acadêmico; (ii) busca de doações para sensibilização de instâncias governamentais; (iii) desenvolvimento de pesquisa para captação de recursos e desenvolvimento do conhecimento; (iv) projetos para cursos de extensão, inclusive com oferta de cursos de verão; (v) desenvolvimento de parcerias e/ou convênios com outras prefeituras através dos consórcios intermunicipais de saúde.

Os sindicatos, associações de classe, associações de usuários de serviços de saúde seriam instâncias politicas parceiras na concretização da missão do HC. O relacionamento com o setor privado consistiria na busca de apoio político e financeiro, através da sensibilização sobre a importância social do $H C$, respeitados os limites de sua missão. Sobre as relações internas na Universidade, a compreensão foi de que o HC já seria um espaço privilegiado de interação entre as diversas unidades e que, deveria buscar a ampliação dessa característica. Entendeu-se que seria necessário o apoio da reitoria para a implementação das mudanças contidas na proposta. $O$ afastamento do MEC como financiador das atividades do $\mathrm{HC}$ fez com que $\mathrm{o}$ $\mathrm{HC}$ se tornasse inteiramente integrado ao SUS municipal e estadual. Portanto, seria necessária intensa negociação com o SUS sobre financiamento, referência e contra-referência, etc., a partir de diretrizes definidas pelo $\mathrm{HC}$, de acordo com sua missão. 
A politica de recursos humanos seria um elemento estratégico para que a missão do $\mathrm{HC}$ fosse alcançada. Foi destacada a especificidade da área de saúde no que diz respeito às implicações éticas relacionadas ao trabalhador do hospital e à clientela. O foco do desenvolvimento de recursos humanos visava preparar as pessoas para a mudança, diante da necessidade de incorporar novas atividades e que viessem refletir no desempenho global. A nova politica de $\mathrm{RH}$ seria realizada com o Programa de Lideranças e de Desenvolvimento de Recursos Humanos - PLIDERH. Para a implementação do PLIDERH e melhoria da situação do trabalho foram propostas ações de curto e médio prazo, que consistiam em: revisão da politica de gratificação para docentes e criação de remuneração dos profissionais através do pagamento de produtividade; retomada da discussão sobre jornada de 30 horas, melhoria no sistema de comunicação, desburocratização e informatização; busca de parcerias para proporcionar assistência médica aos servidores da UFMG. Algumas questões relacionadas com as relações de trabalho foram consideradas dificultadores para a implementação da politica de RH: politica salarial atual; ausência de mecanismo de reposição de pessoal pelo $\mathrm{MEC}$, obrigando o $\mathrm{HC}$ a contratar servidores com recursos próprios para garantir o seu funcionamento, o que acarretava endividamento; cultura institucional, destacando o receio de privatização do $\mathrm{HC}$ e a resistência à revisão dos processos de trabalho.

Ao discutir a tendência que o $\mathrm{HC}$ deveria seguir, o eixo básico foi o mesmo, ou seja, a racionalização dos custos. Essa conclusão estava expressa na missão, apesar de haver a posição contrária de alguns grupos à utilização 
de palavras que caracterizavam uma determinada linha teórica do pensamento, como eficácia, eficiência, harmonia, humanismo. A eficiência era citada como componente da qualidade, que deveria ser buscada para que a missão do hospital fosse atingida. O modelo gerencial deveria contemplar o custo de todas as ações desenvolvidas - pedagógicas, pesquisa e principalmente assistenciais, e o gerenciamento deveria ter como compromisso a redução de custos, sem prejuizo de qualidade. Deveria buscar alternativas que conjugassem a elevação da produtividade com redução de custos. Algumas estratégias foram sugeridas como "gerência mais moderna"; "leito-dia", "desospitalização" e "ambulatorização" - a realização, no ambulatório, de procedimentos diagnósticos e terapêuticos. A busca da eficiência foi representada por: desenvolvimento de protocolos; utilização de mecanismos de controle de custos e gastos de material; todos os trabalhadores deveriam ter o conhecimento do real custo dos procedimentos realizados - com mudança de hábitos e de cultura para eliminar desperdicio; definição de critérios de incorporação de tecnologia baseada em noção de custo-beneficio; apuração dos custos hospitalares para aferição do desempenho; gestão baseada em resultados e que as pesquisas realizadas no $\mathrm{HC}$ cobrissem seus custos. Um importante questionamento foi apresentado sobre como $\circ \mathrm{HC}$ poderia ser economicamente competitivo, ao mesmo tempo em que ofereceria ensino e assistência e desenvolveria pesquisa de qualidade. 
TABELA 9. Sintese das categorias analisadas no relatório final do III Seminário do Hospital das Clinicas/UFMG, Belo Horizonte, $1998^{27}$

Missão: desenvolver, eficaz e eficientemente, e de forma equilibrada, a formaçăo e a capacitaçăo de recursos humanos e a pesquisa na área da saúde, e a assistência, respondendo às necessidades de saúde da populaçăo e, inserido no Sistema de Saúde do Estado de Minas Gerais, constituir-se como referência para áreas especificas

\begin{tabular}{|c|c|c|c|c|c|c|c|}
\hline $\begin{array}{c}\text { Organizaçăo e } \\
\text { Estrutura }\end{array}$ & $\begin{array}{c}\text { Modelo Assistencial } \\
\text { Pedagógico }\end{array}$ & Gestăo & Público & Financlamento & $\begin{array}{c}\text { Relaçoes } \\
\text { Institucionals }\end{array}$ & Relaçōes de Trabalho & Eficiência \\
\hline 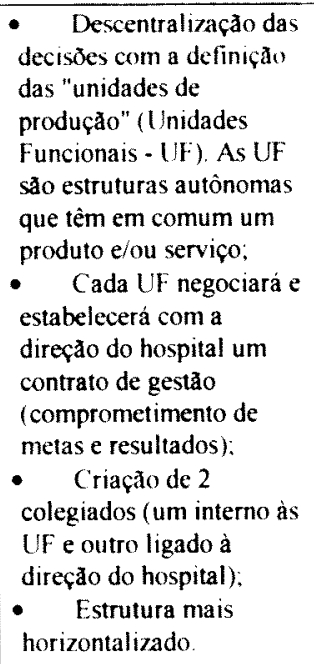 & $\begin{array}{l}\text { - Indissociabilidade } \\
\text { entre ensino, pesquisa e } \\
\text { assistência; } \\
\text { - Formą̧ão e } \\
\text { capacitaça de recursos } \\
\text { humanos, pesquisa na } \\
\text { area de saude. } \\
\text { integrando-os com } \\
\text { assistência, para } \\
\text { responder às } \\
\text { necessidades de saude } \\
\text { da populaçăa; } \\
\text { - A assistência é } \\
\text { orientadora do processo } \\
\text { pedagógico. }\end{array}$ & $\begin{array}{l}\text { O projeto gerencial } \\
\text { do HC deve ser coerente } \\
\text { com a missão do } \\
\text { hospital; } \\
\text { Diretrizes: } \\
\text { descentralizaçăo das } \\
\text { decisðes e } \\
\text { responsabilidades: } \\
\text { autonomia gerencial; } \\
\text { planejamento estratégico } \\
\text { e participativo, definiçăo } \\
\text { de metas; baseado nos } \\
\text { resultados e na } \\
\text { racionalizaçăo de } \\
\text { recursos; compromisso } \\
\text { com a qualidade do } \\
\text { atendimento; } \\
\text { transparência } \\
\text { administrativa e } \\
\text { liderança pró-ativa. }\end{array}$ & $\begin{array}{l}\text { Com a inserçåo do } \\
\text { HC no SUS, a discussào } \\
\text { sobre o que é publico é } \\
\text { direcionada para o } \\
\text { contexto externo, de } \\
\text { politicas } \\
\text { governamentais; } \\
\text { O O modelo } \\
\text { organizacional adotado } \\
\text { poderia levar a } \\
\text { privatizaçăo: } \\
\text { - Proposto a criaçào } \\
\text { do Conselho de } \\
\text { Usuários do HC com } \\
\text { representantes de toda a } \\
\text { sociedade. }\end{array}$ & $\begin{array}{l}\text { - Financiamento } \\
\text { via orçamento (MEC) } \\
\text { pagamento de parte } \\
\text { da folha salarial, } \\
\text { recursos próprios. } \\
\text { provenientes da } \\
\text { venda de serviços ao } \\
\text { SUS, planos de saúde } \\
\text { privado e } \\
\text { particulares: } \\
\text { Os convènios } \\
\text { com o municipio e } \\
\text { estado são recursos } \\
\text { adicionais, } \\
\text { geralmente voltados } \\
\text { suprir carências } \\
\text { assistenciais do } \\
\text { sistema de saude. }\end{array}$ & $\begin{array}{l}\text { - As relaçð̄es com } \\
\text { a sociedade såo } \\
\text { fundamentais para } \\
\text { cumprir a missão e } \\
\text { angariar apoio } \\
\text { politico para a } \\
\text { manutençăo e } \\
\text { ampliaçăo das } \\
\text { atividades do HC; } \\
\text { Principais } \\
\text { interlocutores } \\
\text { externos são o } \\
\text { governo municipal, } \\
\text { estadual e federal; } \\
\text { - Espaço } \\
\text { privilegiado de } \\
\text { interaçăo entre as } \\
\text { unidades acadèmicas. }\end{array}$ & $\begin{array}{l}\text { Elemento } \\
\text { estrategico para que a } \\
\text { misså do IIC seja } \\
\text { alcançada: } \\
\text { - Centrada na ética } \\
\text { da responsabilidade. } \\
\text { - Avaliaçà de } \\
\text { desempenho, ligada ao } \\
\text { planejamento e } \\
\text { capacitaçăo permanente; } \\
\text { - Melhoria da } \\
\text { qualidade de vida no } \\
\text { trabalho; } \\
\text { - Avaliação deve } \\
\text { refletir o desempenho do } \\
\text { hospital; } \\
\text { - Importância do } \\
\text { pagamento de } \\
\text { produtividade }\end{array}$ & $\begin{array}{l}\text { - Racionalizaça dos } \\
\text { custos c componentic da } \\
\text { qualidade: } \\
\text { - Deve ser buscada } \\
\text { para que a missáo do } \\
\text { hospital seja cumprida; } \\
\text { - Apresentada como } \\
\text { meio de sobrevivencia. }\end{array}$ \\
\hline
\end{tabular}

\footnotetext{
${ }^{27}$ Foram analisados em conjunto o "Projeto para implantação de um novo modelo de geståo no HC/UFMG - Unidades Funcionais de 1999; o texto "Papel e atribuições dos Colegiados" e o de "Contrato de Gestão das UF" de 2000.
} 


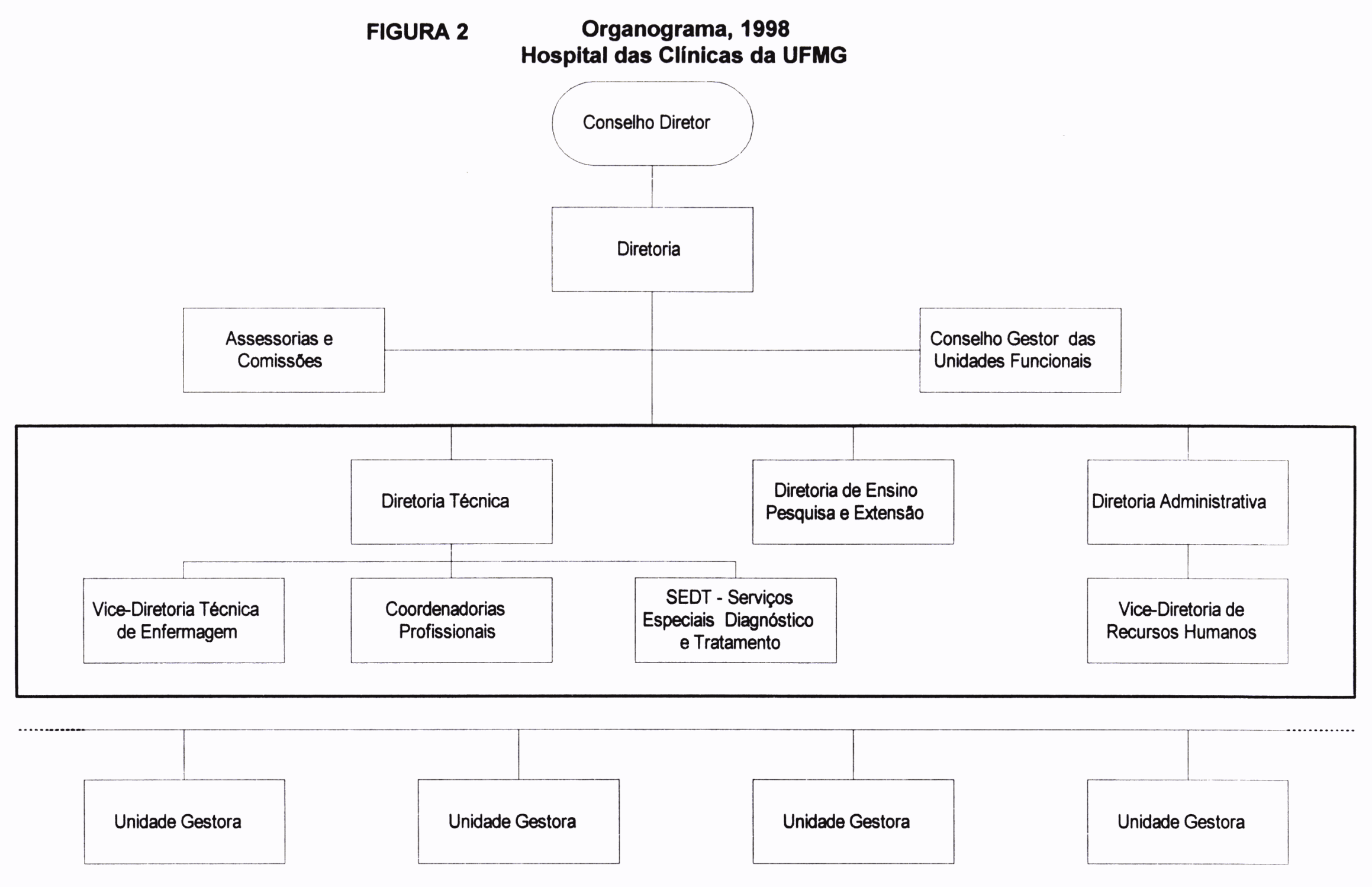


A sistematização das categorias do Plano Diretor de 1998-2000 é apresentada na Tabela. 10. O propósito do Plano Diretor foi seguir as diretrizes estabelecidas no III Seminário, que definiu a missão do hospital. Apresentava os programas de trabalho, sendo o Programa Desenvolvimento Institucional caracterizado como a adequação da organização como um todo, para cumprir as novas diretrizes políticas estabelecidas e atender as exigências daí decorrentes. Um dos itens listados para alcançar esse objetivo foi a definição do organograma do hospital e reestruturação de seus órgãos colegiados, inclusive de suas inter-relações, competências e atribuições. Também foram definidos as instâncias, os prazos e as responsabilidades pela implantação da nova politica para o $\mathrm{HC}$, buscando agilizar este processo e inserindo as correçōes e ajustes do plano, no horizonte político dos dois anos seguintes. Esse projeto global foi denominado de Projeto de Revitalização do HC.

O desenvolvimento do modelo assistencial estabeleceu subprojetos: otimização dos leitos, fim da sazonalidade, ampliação de leitos, ampliação da produção do centro cirúrgico, melhoria do fluxo no pronto atendimento; mudança na forma de acesso dos usuários às consultas, introduzindo a marcação pela central de marcações da SMS/BH; atenção domiciliar, evitando internações; credenciamento SUS.

Os projetos de credenciamento encaminhados aos gestores municipal e estadual, para inclusão do HC na Rede Estadual de Referência, financiada pelo Ministério da Saúde, traria para o hospital recursos adicionais de 
custeio, através da melhor remuneração de internações, além de preveremse recursos de investimentos. No projeto de modernização administrativa, no item receita e despesas, foram apresentados os sub-projetos: (i) Convênio Global, que seria assinado com a SMS/BH, ampliando a oferta de procedimentos ambulatoriais, incluindo a alta complexidade e internaçōes hospitalares de setores de ponta como oftalmologia e transplantes; (ii) Faturamento SUS, que consistia na revisão dos processos de registro de produção e faturamento; (iii) ampliação do número de leitos e criação de ambulatório especifico para particulares e convênios; (iv) negociação de convênios com outras prefeituras para utilização dos serviços não comprados pelo SUS/BH; (v) desenvolvimento de projetos de pesquisa de interesse acadêmico cujo financiamento fosse suficiente para o seu custeio e de investimentos no hospital.

No plano das relaçōes institucionais foi proposto o Projeto de Marketing para que a marca $\mathrm{HC}$ fosse respeitada pelos compradores de serviços e pela sociedade em geral, com a divulgação de informações sobre atividades desenvolvidas no hospital. Dentro do projeto de marketing foi citada a busca de parcerias com empresas privadas e incentivo a doações. 


\begin{tabular}{|c|c|c|c|c|c|c|}
\hline $\begin{array}{c}\text { Organização e } \\
\text { Estrutura }\end{array}$ & $\begin{array}{c}\text { Modelo } \\
\text { Assistencial } \\
\text { Pedagógico }\end{array}$ & Gestão & Financlamento & $\begin{array}{c}\text { Relaçōes } \\
\text { Instltucionals }\end{array}$ & $\begin{array}{c}\text { Relaçס̄es de } \\
\text { Trabalho }\end{array}$ & Eficiência \\
\hline $\begin{array}{l}\text { - Programa } \\
\text { Desenvolvimento } \\
\text { Institucional: } \\
\text { adequação da } \\
\text { organizaçåo como um } \\
\text { todo, para cumprir as } \\
\text { diretrizes políticas } \\
\text { estabelecidas, com } \\
\text { redefiniçăo do } \\
\text { organograma do } \\
\text { hospital e } \\
\text { reestruturaçåo de seus } \\
\text { orgăos colegiados, } \\
\text { inclusive de suas inter- } \\
\text { relaçסes, } \\
\text { competéncias e } \\
\text { atribuiçठ̌es. Esse } \\
\text { projeto global foi } \\
\text { denominado Projeto de } \\
\text { Revitalizaçåo do HC, e } \\
\text { obedece as diretrizes } \\
\text { do III Seminário. }\end{array}$ & $\begin{array}{l}\text { - Indissociabili- } \\
\text { dade do ensino, } \\
\text { pesquisa e } \\
\text { assisténcia; } \\
\text { - O Hospital é } \\
\text { uma instituiçăo } \\
\text { universitária pública } \\
\text { inserida na rede } \\
\text { pública de saúde, } \\
\text { preservando } \\
\text { caracteristicas } \\
\text { peculiares de um } \\
\text { hospital de ensino. }\end{array}$ & $\begin{array}{l}\text { - O projeto } \\
\text { gerencial do HC deve } \\
\text { ser coerente com a } \\
\text { missăo do hospital; } \\
\text { - Diretrizes: } \\
\text { descentralizaçăo das } \\
\text { decisóes e } \\
\text { responsabilidades; } \\
\text { autonomia gerencial; } \\
\text { planejamento } \\
\text { estrategico e } \\
\text { participativo, definiçăo } \\
\text { de metas; baseado } \\
\text { nos resultados e na } \\
\text { racionalizaçăo de } \\
\text { recursos; logica do } \\
\text { compromisso com a } \\
\text { qualidade do } \\
\text { atendimento; } \\
\text { transparéncia } \\
\text { administrativa e } \\
\text { liderança pró-ativa. }\end{array}$ & $\begin{array}{l}\text { - Projetos de } \\
\text { credenciamento dentro da } \\
\text { Rede Estadual de Referencia } \\
\text { (melhor remuneraçăo de } \\
\text { internaçoes e recursos de } \\
\text { investimentos); } \\
\text { - Projeto de Convênio } \\
\text { Global com a SMS/BH, } \\
\text { - Melhoria dos processos de } \\
\text { registro de produçăo e } \\
\text { faturamento; ampliaçăo do } \\
\text { número de leitos e criaçăo de } \\
\text { ambulatorio especifico para } \\
\text { particulares e convénios; } \\
\text { - Negociaçăo de convenios } \\
\text { com outras prefeituras para } \\
\text { utilizaçăo dos serviços náo } \\
\text { comprados pelo SUS/BH; } \\
\text { - Desenvolvimento de } \\
\text { projetos de pesquisa de } \\
\text { interesse académico cujo } \\
\text { financiamento seja suficiente } \\
\text { para o custeio das mesmas e } \\
\text { investimentos no hospital. }\end{array}$ & $\begin{array}{l}\text { - Consolidar o papel } \\
\text { do HC como referéncia } \\
\text { secundária, terciária e } \\
\text { quaternária para o } \\
\text { SUS, apresentando } \\
\text { aos gestores municipal } \\
\text { e estadual projetos de } \\
\text { inclusăo do HC na } \\
\text { Rede Estadual de } \\
\text { Referência; } \\
\text { - Projeto de } \\
\text { Marketing para que a } \\
\text { marca HC seja } \\
\text { respeitada pelos } \\
\text { compradores de } \\
\text { serviços e pela } \\
\text { sociedade em geral; } \\
\text { - Busca de } \\
\text { parcerias com } \\
\text { empresas privadas e } \\
\text { incentivo a doaçठes. }\end{array}$ & $\begin{array}{l}\text { - Gestăo de RH } \\
\text { é baseada na } \\
\text { valorizaçăo das } \\
\text { pessoas e na busca } \\
\text { de suas } \\
\text { potencialidades; } \\
\text { Programa de } \\
\text { Programa de } \\
\text { Gestăo de } \\
\text { Desempenho } \\
\text { (PLIDERH), cuja } \\
\text { característica } \\
\text { principal é a } \\
\text { definiçăa de açóes } \\
\text { necessárias ao } \\
\text { alcance de objetivos } \\
\text { e metas de cada } \\
\text { setor. }\end{array}$ & $\begin{array}{l}\text { - O Projeto de } \\
\text { Revitalização e } \\
\text { seus sub projetos } \\
\text { (sistemas de custos, } \\
\text { informatizaçăo, de } \\
\text { RH, de otimizaçáo } \\
\text { dos leitos) procuram } \\
\text { aumentar a } \\
\text { produçăo de todos } \\
\text { os serviços, } \\
\text { utilizaçăo da } \\
\text { capacidade ociosa, } \\
\text { ou do aumento da } \\
\text { produtividade, } \\
\text { assegurando a } \\
\text { qualidade dos } \\
\text { processos e } \\
\text { resultados. }\end{array}$ \\
\hline
\end{tabular}


As sinteses do Plano Diretor de 2000-2002, segundo as categorias, são apresentadas na Tabela 11. A proposta expressa a continuidade do projeto de reestruturação administrativo-gerencial, que visava a descentralização das decisões a partir de um processo de planejamento participativo, com a elaboração de metas e compromissos pactuados com a direção do Hospital. Foi realçado, no documento, que a marca da gestão seria a de viabilizar projetos de cunho estritamente institucional, duradouros, extrapolando os mandatos.

No plano de atuação político administrativo, o propósito era de dar continuidade aos projetos e diretrizes em curso, conforme os fóruns de deliberação instituídos. $O$ modelo gerencial baseado nas Unidades Funcionais estava, em alguns setores, em fase avançada de implantação. As Unidades Funcionais seriam constituidas por um conjunto de recursos humanos, materiais e área física agrupados por identidade quanto à sua atividade principal. As unidades seriam as células administrativas do hospital, dotadas de autonomia para gestão de recursos e gerenciamento de processos, com estrutura multidisciplinar. A pactuação de metas de trabalho entre a unidade funcional e a diretoria, dar-se-ia através de contratos de gestão. As características destas unidades eram: existência de equipes estáveis, com processos de trabalho definidos e semelhantes ou com grande relação entre si, responsáveis por determinados produtos que eram consumidos por determinados usuários. As Unidades Funcionais (UF) teriam gestão descentralizada, podendo, a partir da definição da sua missão específica, compatibilizada com a missão geral do $\mathrm{HC}$, seus objetivos e 
metas, realizar o planejamento e reorganizar internamente o seu processo de trabalho visando um melhor desempenho de seus serviços. A gestão de recursos humanos teria importância decisiva na implementação das mudanças propostas. As Unidades Funcionais deveriam compatibilizar os diversos objetivos específicos de maneira a promover a otimização das relaçōes entre os serviços/setores e as unidades acadêmicas, como integração do ensino, pesquisa e assistência.

No plano de atuação político institucional a administração deveria dar continuidade ao processo de inserção e integração do Hospital das Clínicas ao SUS, preservando as caracteristicas peculiares de um hospital universitário. Nessa negociação deveria haver, em contrapartida, um compromisso por parte dos gestores de saúde municipal e estadual, com a viabilização financeira do Hospital das Clínicas.

A atuação administrativo-financeira proposta nesse Plano Diretor consistia em: compromisso com a viabilização financeira do Hospital das Clínicas, respeitando as normas já estabelecidas de dispor no minimo $70 \%$ de sua capacidade para atendimento ao SUS; utilizar todo o potencial do hospital na geração de recursos, através da prestação de serviços e treinamentos; trabalhar para captar recursos para projetos de ensino, pesquisa e pósgraduação, oriundos tanto de fontes acadêmicas como de organismos de fomento nacionais e internacionais. Os programas listados como geradores de receita foram assim descritos: (i) Convênio Global: as mudanças ocorridas na Secretaria Municipal de Saúde, as novas regras colocadas para a concessão e manutenção do FIDEPS e a mudança da tabela de 
procedimentos ocorridas no final de 1999 levaram a um retrocesso das discussões do Convênio Global. No final de maio/2000 foi enviada ao Gestor Municipal nova proposta de planilha, mais adequada à capacidade de produção do Hospital, com perspectivas de ampliações que deveriam ser precedidas de estudo de viabilidade financeira. A execução da planilha proposta poderia levar a aumento de $32 \%$ na arrecadação. (ii) Faturamento SUS: nos 2 anos anteriores, o faturamento SUS tivera incremento de $35 \%$. A arrecadação SUS teria potencial de crescimento com os futuros credenciamentos/reclassificações, ampliação de procedimentos melhor remunerados (CCV, transplantes, quimioterapia) e negociação do FIDEPS proporcional à produção. (iii) Particulares e Convênios - o Hospital vinha concentrando esforços no sentido de ampliar a inserção de clientela particular e de convênios, diversificando o atendimento e auferindo recursos adicionais ao seu orçamento. Segundo o Plano Diretor, em 1999, comparativamente a 1997, a ampliação da receita fora de 136\%. Em 1999 tinham sido assinados 7 novos convênios e o setor de Faturamento de Convênios fora ampliado, com novas instalações e contratação de funcionário com experiência. (iv) Outras Prefeituras - negociação de convênios com outras prefeituras para utilização dos serviços não comprados pelo SUS/BH. (v) Desenvolvimento de Projetos de Pesquisa e de Extensão - rediscutir a política e a sistematização das atividades de Pesquisa e Extensão desenvolvidas no $\mathrm{HC}$, de modo que os custos decorrentes destas atividades fossem integralmente cobertos pelos agentes financiadores e/ou patrocinadores. Propor alternativas para utilização destas 
atividades como meio de captação de recurso para fins de investimento na infra-estrutura e principalmente custear projetos de pesquisa sem financiamento. Foram estabelecidos normas e critérios para análise dos projetos de pesquisa a serem desenvolvidos.

Era propósito do Plano Diretor de 2000-2002 introduzir no HC a cultura da qualidade e a melhoria contínua dos processos produtivos através de duas linhas de ação estratégicas: implantação de um Sistema de Acreditação Hospitalar e busca de certificação especifica em Medicina Laboratorial. O Hospital submeteu-se, no ano de 1999, a uma avaliação interna baseada nos requisitos propostos pelo Programa Brasileiro de Acreditação Hospitalar e estava se organizando para certificar-se, junto ao Ministério da Saúde, como hospital "acreditado". Como plano de atuação para o desenvolvimento do modelo assistencial, reafirmou-se que a qualidade do ensino depende da qualidade da assistência.

Algumas políticas implementadas estavam proporcionando: a) maior integração das unidades acadêmicas da UFMG, com criação de novos espaços e atividades de ensino e assistência, tornando o HC um local privilegiado para o exercício da interdisciplinaridade indispensável à assistência integral à saúde; b) parcerias com o sistema público de saúde tinham possibilitado aumento de leitos, cirurgias, atendimentos, receitas, etc. A proposta de atuação político administrativa contida no documento reafirmou as seguintes linhas de trabalho: (i) dar continuidade à parceria com a Reitoria e as Unidades Acadêmicas que atuavam no Hospital das Clínicas; (ii) dar continuidade às parcerias com o setor público que permitiam 
a viabilização financeira e dos projetos acadêmico-assistenciais. Ao descrever o modelo assistencial, a única menção sobre relação externa foi o destaque que o Hospital das Clínicas deveria inserir-se em todas as formas sociais de prestação de serviços, obrigando-se a ser competitivo em todas elas.

Foi citado o PLIDERH como motivador e produtor de avanços nas relações de trabalho no âmbito do HC. O PLIDERH estruturava-se através do Programa de Gestão de Desempenho, devendo ser o gerador de informações que subsidiariam outros programas instituidos de acordo com o estágio de desenvolvimento da área de RH: Programa de capacitação; Programa de qualidade de vida; Programa de movimentação e acompanhamento funcional; Programa de incentivo ao desempenho funcional. É interessante observar que na exposição das diretrizes básicas de cada programa, "criar condições para uma reflexão critica do servidor acerca de seu desempenho, em relação aos objetivos institucionais" era comum a todos. Dois problemas foram relacionados ao serem detalhados os sub-projetos para Pronto Atendimento e Regularidade da Assistência: (i) a necessidade de um maior envolvimento e compromisso dos profissionais e maior inserção do quadro de funcionários do PA nos diversos serviços do HC e a variedade de vínculos contratuais com predomínio dos RPA; (ii) a necessidade de manutenção do padrão de produção/arrecadação nos periodos de férias o que dependia da discussão com as Unidades Acadêmicas que atuavam no HC. Também foi considerada a possibilidade de contratação temporária de profissionais. 
TABELA 11 - Sintese das categorias analisadas no Plano Diretor do Hospital das Clinicas/UFMG de 2000-2002

\begin{tabular}{|c|c|c|c|c|c|c|}
\hline $\begin{array}{c}\text { Organização e } \\
\text { Estrutura }\end{array}$ & $\begin{array}{c}\text { Modelo Assistencial } \\
\text { Pedagógico }\end{array}$ & Gestão & Financiamento & $\begin{array}{c}\text { Relações } \\
\text { Institucionais }\end{array}$ & $\begin{array}{l}\text { Relações de } \\
\text { Trabalho }\end{array}$ & Eficiência \\
\hline $\begin{array}{l}\text { - Adequar a } \\
\text { organização para } \\
\text { o cumprimento } \\
\text { das novas } \\
\text { diretrizes } \\
\text { politicas } \\
\text { estabelecidas e } \\
\text { contidas na } \\
\text { missăo } \\
\text { Institucional } \\
\text { definida no III } \\
\text { Seminário (1998); } \\
\text { - Viabilizar } \\
\text { projetos de cunho } \\
\text { estritamente } \\
\text { institucional, } \\
\text { duradouros, } \\
\text { extrapolando os } \\
\text { mandatos. }\end{array}$ & $\begin{array}{l}\text { - Indissociabilidade do ensino } \\
\text { e assistência; } \\
\text { - Assistência de qualidade é } \\
\text { fator determinante para o ensino } \\
\text { de qualidade; } \\
\text { - O hospital como local } \\
\text { privilegiado para o exercicio da } \\
\text { interdisciplinaridade; } \\
\text { - Deve estar inserido } \\
\text { competitivamente em todas as } \\
\text { formas sociais de prestação de } \\
\text { serviços; } \\
\text { - Vocaçăo para as atividades } \\
\text { de maior complexidade, no } \\
\text { entanto continuará prestando } \\
\text { atenção primária vinculada a } \\
\text { projetos especiais de ensino e } \\
\text { pesquisa; } \\
\text { - As Unidades Funcionais } \\
\text { deverăo compatibilizar os } \\
\text { diversos objetivos especlficos de } \\
\text { maneira a promover a otimizaçăo } \\
\text { das relaçð̋es entre os } \\
\text { serviços/setores e as unidades } \\
\text { académicas, e a integração do } \\
\text { ensino, pesquisa e assistência. }\end{array}$ & $\begin{array}{l}\text { - Modelo gerencial } \\
\text { baseado nas Unidades } \\
\text { Funcionais - UF (em } \\
\text { implantaçăo), tendo } \\
\text { como principios: } \\
\text { gestăo democrática, } \\
\text { participativa e } \\
\text { transparente; } \\
\text { - As UF săo células } \\
\text { administrativas do } \\
\text { hospital, dotadas de } \\
\text { autonomia para gestăo } \\
\text { de recursos e } \\
\text { gerenciamento de } \\
\text { processos, com } \\
\text { estrutura } \\
\text { multidisciplinar e } \\
\text { estruturadas através } \\
\text { de metas de trabalho e } \\
\text { resultados } \\
\text { estabelecidas de } \\
\text { comum acordo entre a } \\
\text { equipe da UF e a } \\
\text { diretoria, através de } \\
\text { contratos de gestăo. }\end{array}$ & $\begin{array}{l}\text { - Projeto de Convênio } \\
\text { Global com a SMS/BH } \\
\text { (pagamento global por } \\
\text { serviços prestados ao } \\
\text { SUS/BH); } \\
\text { - Potencial de } \\
\text { crescimento da arrecadaçăo } \\
\text { SUS com os } \\
\text { credenciamentos/reclassifica } \\
\text { çóes, ampliaçăo de } \\
\text { procedimentos melhor } \\
\text { remunerados; } \\
\text { - Ampliaçăo da inserçăo } \\
\text { de clientela particular e de } \\
\text { convênios; } \\
\text { convênios comáo de } \\
\text { preftras } \\
\text { dos serviços năo comprados } \\
\text { pelo SUS/BH; } \\
\text { projetosenvolvimento de } \\
\text { projetos de pesquisa de } \\
\text { interesse académico cujo } \\
\text { financiamento seja suficiente } \\
\text { para o seu custeio e } \\
\text { investimentos no hospital. }\end{array}$ & $\begin{array}{l}\text { - OHC deve estar } \\
\text { inserido em todas as } \\
\text { formas sociais de } \\
\text { prestaçăo de serviços, } \\
\text { obrigando-se a ser } \\
\text { competitivo em todas } \\
\text { elas; } \\
\text { das Maior integração } \\
\text { dasidades } \\
\text { académicas da UFMG } \\
\text { e Reitoria, com } \\
\text { criaçăo de novos } \\
\text { espaços e atividades } \\
\text { de ensino e } \\
\text { assistência; } \\
\text { - Parcerias com o } \\
\text { sistema público de } \\
\text { saúde têm } \\
\text { possibilitado a } \\
\text { viabilizaçăo financeira } \\
\text { do hospital e dos } \\
\text { projetos académico- } \\
\text { assistenciais. }\end{array}$ & $\begin{array}{l}\text { - PLIDERH é } \\
\text { citado como } \\
\text { motivador e } \\
\text { produtor de } \\
\text { avanços nas } \\
\text { relaços de } \\
\text { trabalho do HC; } \\
\text { Substituição dos } \\
\text { Sub programas: } \\
\text { capacitaçăo; } \\
\text { qualidade de vida; } \\
\text { movimentaçăo e } \\
\text { acompanhamento } \\
\text { funcional e } \\
\text { Programa de } \\
\text { incentivo ao } \\
\text { desempenho } \\
\text { funcional. }\end{array}$ & $\begin{array}{l}\text { - A estrutura } \\
\text { gerencial visa } \\
\text { otimizar a gestão } \\
\text { dos recursos } \\
\text { humanos, } \\
\text { financeiros e } \\
\text { materiais, e açőes } \\
\text { de planejamento } \\
\text { que implicam na } \\
\text { definiçåo de } \\
\text { prioridades, } \\
\text { elaboraçåo de } \\
\text { indicadores e } \\
\text { definição de } \\
\text { metas } \\
\text { assistenciais, } \\
\text { financeiras, de } \\
\text { ensino, pesquisa } \\
\text { e extensão. }\end{array}$ \\
\hline
\end{tabular}




\subsubsection{Análise das Atas do Conselho Administrativo do HC/UFMG}

Nas Tabelas 32 a 38 (ANEXO 5) apresentamos um resumo dos assuntos discutidos e das decisões tomadas pelo Conselho Administrativo (CA) do HC, nos anos de 1994 a 2000. O CA é um grande colegiado - instância políticodeliberativa, no molde das estruturas da universidade, com composição representativa dos grupos de interesses que atuam no $\mathrm{HC}$ (Diretores das Faculdades que atuam no hospital, chefes de departamento da medicina e enfermagem, representação do corpo discente das Unidades constituintes do $\mathrm{CA}$, representante dos residentes e representação dos funcionários técnicos e administrativos lotados no Hospital das Clínicas) e de toda a estrutura orgânico-gerencial. É presidido pelo Diretor da Faculdade de Medicina. Na leitura das atas podemos perceber que, cada vez mais, o CA vem atuando como instância politica deliberativa na qual são dirimidos os conflitos e tomadas as decisões maiores. Esta observação pode ser corroborada pelo número de reuniōes realizadas ou atas transcritas encontradas e o número de decisões tomadas. Em 1994 foram 14 reuniões e 12 decisões aprovadas (resoluções, portarias, criação de comissões e pareceres de comissão), em 1995, 18 sessões e 9 decisões; em 1996, 19 sessões e 5 decisões foram tomadas; em 1997 foram 15 reuniões e 7 decisões; em 1998 aconteceram 10 sessões com 5 decisões tomadas. O ano de 1999 parece atípico, pois só foram encontradas atas de 3 sessões que levaram a 1 decisão. Em 2000 foram 07 sessões e 4 tomadas de decisão. Como todo órgão colegiado, as decisões são extremamente morosas, pois as questões são exaustivamente discutidas, com várias idas e vindas e, geralmente, as decisões são consensuadas. 
Vemos que este Conselho tem discutido principalmente temas sobre relações de trabalho (conflitos inter e intra-segmentos e categorias profissionais, entre gerência e trabalhadores, jornadas especiais de trabalho) e reestruturação/organização do HC. Desde 1995, quando foi instituida a comissão para a reformulação do regimento do $\mathrm{HC}$, este assunto vem sendo exaustivamente discutido, sofrendo modificações a cada mudança na correlação de forças entre as representações no CA. É interessante observar que uma grande crise nas relações de trabalho, na qual o CA teve papel destacado, deveu-se ao cumprimento da Constituição de 1988 e do RJU. Foi extremamente conflituosa e traumática a substituição dos trabalhadores CLT (FUNDEP) pelos novos concursados dentro do RJU. O tema da eficiência (do HC) pouco aparece nas Atas do CA. Esporadicamente algum Conselheiro levantava alguma questão pertinente ao assunto, mas não era motivo de debate.

Em relação ao financiamento do HC, foi aprovado, em 4 de agosto de 1994, o parecer da comissão que estudou as propostas para elaboração de novas políticas para o perfil da clientela a ser atendida pelo hospital. Definiu-se que "os parâmetros para a determinação da ocupação dos leitos hospitalares existentes deverão estar contidos naqueles do convênio HC/SUS". À clientela do SUS seria destinado o mínimo de $70 \%$ dos leitos hospitalares e, havendo ampliação da quantidade de leitos do hospital, poderiam ser destinados até $30 \%$ dos leitos para convênios e particulares (Resolução 10/94). A partir desta resolução a relação com os financiadores/compradores de serviços, na maioria das vezes, era negociada pela Diretoria Geral, sendo posteriormente 
referendada as assinaturas dos convênios, como, por exemplo, com a UNIMED (em 21 de junho de 1995) ou com a SMS/BH para a abertura do Pronto Atendimento, em 17 de abril de 1996.

É interessante destacar que o tema da reforma do Estado (autonomia universitária, organizações sociais, etc) foi pouco discutido, sobressaindo-se, no entanto duas situações paradigmáticas. A primeira foi um manifesto do Conselho Administrativo à proposta de transformação dos hospitais universitários em organizações sociais, discutida em várias sessões do CA, aprovando-se em 3 de maio de 1995 o documento "Manifestação do Conselho Administrativo do HC/UFMG sobre a política para os Hospitais Universitários", cujos principais pontos foram: a) o projeto dos HU devia ser confrontado ao projeto de estado brasileiro, não se aceitando, simplesmente, a transferência de ônus da instância federal para a estadual e municipal, mas reafirmando-se o projeto social no qual a instância federal não podia se excluir, em detrimento de seus deveres para com a sociedade; b) os HU tinham como objetivos indissociáveis assistência, ensino, pesquisa, o que o diferencia dos demais serviços de saúde; c) os HU deviam prestar serviços em todos os níveis, do primário ao quaternário, prevenção, cura ou reabilitação, devendo desenvolver e incorporar tecnologias; d) a questão de fundo nas discussões sobre a forma organizativa ou modelo jurídico dos HU era política, considerando: a politica de implantação do SUS; a valorização e financiamento dos setores de educação e saúde; e as respostas que deviam ser dadas às demandas sociais; e) os HU eram parte indissociável da universidade, assegurando a escolha de seu dirigente no âmbito da Universidade e estabelecendo relações formais com os 
órgãos de deliberação superior e com as unidades acadêmicas da área de saúde; f) as universidades deviam assumir suas responsabilidades junto aos HU, com apoio politico, jurídico e administrativo e reconhecendo as atividades ali desenvolvidas como universitárias. g) deviam ser instituídos mecanismos urgentes para superação de entraves gerenciais administrativos e financeiros; h) os recursos humanos: a manifestação era pela manutenção do RJU, introduzindo normas de flexibilização que permitiam melhorar a dinâmica de gerência de pessoal, assegurando os direitos e a estabilidade, e que o acesso seria por concurso público; i) deviam ser aprimorados mecanismos de gestão de $\mathrm{RH}$ que valorizassem avaliação, educação permanente e progressão funcional; permitindo mecanismos ágeis, justos e democráticos, para exonerações e reposições de perdas de quadros de pessoal; em caráter complementar podiam ser admitidas formas alternativas de contratação de pessoal para garantir as atividades do hospital.

Outra situação foi a causada pelo Decreto $n^{\circ} 1.590$ de 10 de agosto de 1995 , já dentro do espírito da reforma de Estado. O Decreto $n^{0} 1590$ fixava a jornada dos servidores federais em 40 horas semanais. As jornadas especiais (turno ininterrupto, ou de 30 horas) deveriam ser definidas pelos órgãos que a praticavam, devendo ser publicado no Diário Oficial a relação dos servidores que fizessem jornada especial, a cada seis meses. O Decreto colidiu com o acordo informal de redução da jornada de trabalho, no $\mathrm{HC}$, para algumas categorias de trabalhadores. A crise institucional somente foi contornada, com - CA assumindo o horário especial destas categorias perante o MEC. Entretanto, este assunto permanece conflituoso até os dias atuais. 


\subsubsection{O Conceito de Eficiência nos Documentos do Hospital das Clínicas/UFMG}

É interessante observar que a presença do conceito de eficiência, já detectável no seminário de 92 , vai tornando-se mais freqüente e natural, permeando todas as atividades e procedimentos do hospital, nos Planos Diretores e Seminário subseqüentes. Se em 1992 a idéia de eficiência era apresentada, de uma maneira geral, para melhorar o comportamento do hospital, em 1998 é apresentada como forma de sobrevivência. Chama atenção que o vocábulo eficiência e seus correlatos, diferentemente do que foi observado nos documentos elaborados pelo MARE, pouco é utilizado nos produzidos pelo HC. Em seu lugar o conceito é apresentado como "otimização de recursos", "aumento da produção com redução de custos", "aumento da produtividade", "relação custo-beneficios"; "diminuir os desperdícios". Talvez houvesse uma resistência e até mesmo "pudor" em usar esta palavra identificada com o econômico e o privado, referindo-se a um hospital público. No entanto, estão presentes na Imagem-Objetivo retirada do I Seminário (1992) "(...) com elevada efetividade e eficiência, atendendo as necessidades surgidas dos padrões nosológicos (...)" e também na missão institucional definida no III Seminário (1998) "(...) desenvolver, eficaz e eficientemente, e de forma equilibrada (...)".

No Seminário de 1992 e nos Planos Diretores de 1994, 1995 e do biênio 1996 98, os termos são mais utilizados. Talvez houvesse menor resistência ao seu uso. É no Seminário de 1992 que vamos encontrar uma definição para a ineficiência (institucional): "relação inadequada entre o esforço que a sociedade dispensa para criar, operar e manter a instituição e o retorno que the é 
proporcionado". No Plano Diretor de 1994 é colocada uma estreita relação entre descentralização e eficiência "o objetivo central da proposta de descentralização apresentada é a administração eficiente de um hospital deste porte, que não pode ser administrado eficientemente apenas pela sua direção centraf". Por sua vez, no Plano Diretor de 1996-98, existe uma interessante correlação entre desenvolvimento de $\mathrm{RH}$, eficiência, qualidade e equidade.

"Programas de desenvolvimento de seus próprios recursos humanos na busca de condições individuais e institucionais que assegurem pleno conhecimento do papel e dos objetivos do HC/UFMG, garantindo o indispensável envolvimento com a busca de qualidade $e$ eficiência, que na Saúde sempre implicará em equidade".

Nos dois últimos Planos Diretores, são utilizados preferencialmente os termos otimizar, aumento da produtividade e redução de custos. Não obstante, o conceito de eficiência parece entranhar-se nos diferentes setores da vida do hospital. O objetivo expresso no programa de Desenvolvimento Institucional do Plano Diretor de 1998-2000 é:

"o aumento da produção de todos os serviços do HC, através da recuperação da capacidade ociosa, porventura existente, e/ou através do incremento possivel da produtividade encontrada, assegurando a qualidade dos processos e resultados, e colocando os excedentes de produção à disposição para negociação"

Na proposta de gestão de materiais e medicamentos o objetivo é:

"definir padronização, compatibilização de compras com disponibilidade orçamentária e controle de distribuição de materiais e medicamentos, visando otimização do sistema"

O objetivo do novo modelo de gestão, as Unidades Funcionais, é assim expresso no Plano Diretor de 2000-2002:

"Esta estrutura gerencial visa otimizar a gestão dos recursos humanos, financeiros e materiais, bem como as ações de 
planejamento que implicam na definição de prioridades, elaboração de indicadores e definição de metas assistenciais, financeiras, de ensino, pesquisa e extensão".

Este modelo de gestão, as Unidades Funcionais, trabalha com a perspectiva do aumento da produção de todos os serviços do $\mathrm{HC}$, através da utilização da capacidade ociosa, porventura existente, ou através do incremento possivel da produtividade encontrada, assegurando a qualidade dos processos e resultados, e colocando os excedentes de produção à disposição para negociação. Destaca-se que a política de gerenciamento da utilização de leitos e de bloco cirúrgico têm permitido melhoria das taxas de ocupação e permanência, refletindo positivamente na qualidade da assistência e do ensino.

Os valores correlacionados ao conceito de eficiência nos documentos do HC/UFMG estão na Tabela 12.

TABELA 12 - Valores correlacionados ao conceito de eficiência nos documentos do Hospital das Clínicas/UFMG

\begin{tabular}{|l|l|}
\hline \multicolumn{2}{|c|}{ Eficiência } \\
\hline Retorno para a sociedade & Conhecimento da missão institucional \\
Qualidade & Definição de metas \\
Autonomia & Resultados \\
Avaliação de desempenho coletiva & Descentralização \\
Gerência moderna & Equidade \\
Participação & Otimização de recursos \\
Competência & Redução de custos \\
Co-responsabilidade & Relação custo-benefícios \\
Sobrevivência & Aumento da produção \\
\hline
\end{tabular}

Fonte: I e III Seminário do HC, Planos Diretores e Atas do Conselho Administrativo de 1994 a 2000 


\subsection{EFICIÊNCIA E PRODUÇÃO DE SERVIÇOS}

Nesta seção apresentamos os indicadores de produção e produtividade, arrecadação, despesas e indicadores qualitativos (média de permanência, taxa de ocupação e taxa de infecção) do HC/UFMG, entre 1994 e 2000. Todos os dados sobre valores foram corrigidos para valores de dezembro de 2000, utilizando-se o Índice de Preço ao Consumidor Ampliado do Instituto Brasileiro de Geografia e Estatística - IPCA/IBGE.

$\mathrm{Na}$ Tabela 13 são apresentadas as principais fontes de arrecadação do Hospital das Clinicas/UFMG, entre 1994/2000. A prestação de serviços e convênios com outros órgãos públicos são as duas principais fontes de arrecadação para o HC: observamos um crescimento da arrecadação do HC atingindo 38 milhões de reais em 2000. Quando comparamos a evolução da arrecadação, tendo como base 1994, constatamos que houve um crescimento de $136 \%$ entre aquele ano e 2000 . A prestação de serviços é a grande fonte, sendo responsável por $87 \%$ em 2000 de toda arrecadação, com aumento de $106 \%$, entre 1994 e 2000 . Outra fonte importante de receita são os convênios com outras instituições públicas, especialmente com as secretarias de saúde do município e do estado e com órgãos federais, chegando a representar $23 \%$ do total arrecadado, em 1997. Os dados de recursos de convênios com outros órgãos públicos somente estão disponiveis a partir de 1996, quando foram arrecadados 5,6 milhões de reais, provenientes do convênio com a Secretaria de Saúde de Belo Horizonte. Esse convênio visava a implantação do serviço de urgência/emergência clinica no Hospital. O ano de 1997 foi o mais profícuo 
para o HC na celebração de convênios com outros órgãos públicos, mostrando-se uma tendência de queda nas transferências por convênios nos anos seguintes, com ligeira recuperação em 2000. A renda de aplicações financeiras, taxas de editais, etc, têm pequena participação na sua economia, representando, no máximo, $1 \%$ da arrecadação.

$\mathrm{Na}$ análise da arrecadação advinda da prestação de serviços, podemos notar que a proveniente do SUS varia, no periodo estudado, de $91 \%$ a $83 \%$ do valor arrecadado. No entanto, o percentual da receita proveniente de convênios com planos de saúde e com clientela particular no total da receita de prestação de serviços praticamente dobrou entre 1994 e 2000 (9\% e $16,5 \%$, respectivamente). A arrecadação proveniente da prestação de serviços ao SUS cresceu cerca de $89 \%$ e a de convênios e particulares $290 \%$, entre 1994 e 2000.

Apesar de não ser computada como fonte de arrecadação, o pagamento de pessoal vinculado à UFMG, pelo MEC, foi da ordem de 21,2 milhões de reais, em 1997 (1646 servidores estatutários em dezembro daquele ano), 22,5 milhões (1640 servidores) em 1998, 24,2 milhões em 1999 (1589) e de 25 milhões de reais em 2000 (1552 servidores). O montante pago pelo MEC, referente aos servidores lotados no HC representava $65 \%$ do total arrecadado pelo Hospital em 1997, alcançou $76 \%$ em 1998 e caiu para $61 \%$ do total arrecado pelo HC em 2000. 
TABELA 13 - Total arrecado, por fonte, em Real corrigido para valores de dezembro de 2000, Hospital das Clínicas/UFMG, 1994-2000*

\begin{tabular}{|c|c|c|c|c|c|c|c|}
\hline \multirow{2}{*}{ Fonte/Ano } & \multicolumn{7}{|c|}{ ANOS } \\
\hline & 1994 & 1995 & 1996 & 1997 & 1998 & 1999 & 2000 \\
\hline Prestação Serviços & $16.218 .466,00$ & $17.083 .903,00$ & $22.202 .381,00$ & $24.707 .937,00$ & $25.270 .967,00$ & $29.719 .498,00$ & $33.564 .454,00$ \\
\hline sus & $14.801 .728,00$ & $15.467 .608,00$ & $20.603 .169,00$ & $22.808 .103,00$ & $22.366 .392,00$ & $25.692 .125,00$ & $28.039 .893,00$ \\
\hline Convênios/Particular & $1.416 .738,00$ & $1.616 .295,00$ & $1.599 .212,00$ & $1.899 .834,00$ & $2.904 .575,00$ & $4.027 .373,00$ & $5.524 .561,00$ \\
\hline Convênio Orgão Püblico & - & - & $5.688 .219,00$ & $7.631 .648,00$ & $4.251 .544,00$ & $3.137 .581,00$ & $4.280 .877,00$ \\
\hline Outros ${ }^{* \star}$ & - & - & - & $317.639,00$ & $223.252,00$ & $334.956,00$ & $528.148,00$ \\
\hline Total & $16.218 .466,00$ & $17.083 .903,00$ & $27.890 .600,00$ & $32.657 .224,00$ & $29.745 .763,00$ & $33.192 .035,00$ & $38.373 .479,00$ \\
\hline
\end{tabular}

Fonte: Divisão Financeira do Hospital das Clínicas/UFMG

* Valores em Real corrigidos pelo Indice de Preços ao Consumidor Ampliado - IPCAIIBGE

** Outros = renda de aplicações financeira + taxa editais + venda de sucatas e refrigerantes, etc 
Os indicadores de produção hospitalar para o SUS são apresentados na Tabela 14. $\mathrm{O}$ número das $\mathrm{AlH}$ realizadas pelo $\mathrm{HC}$ sofre quedas e recuperações e ao final do periodo mostra um incremento de $49 \%$. Já o valor recebido pelas AlH aumenta apenas $15 \%$ entre 1994 e 2000 , com redução de $25 \%$ no valor médio das AlH. É importante destacar que em 2000 houve greve dos servidores estatutários do HC que durou cerca de 90 dias. Nesse periodo de greve ocorreu redução em torno de $50 \%$ das internações. Observação interessante é o reflexo diferenciado da greve no número e valor das AlH. A queda da produção hospitalar é mais pronunciada no valor do que no número de $\mathrm{AlH}$, respectivamente $24 \%$ e $9 \%$, entre 1999 e 2000.

TABELA 14 - Número e valor (total e médio) de AlH, Hospital das Clinicas/UFMG, 1994-2000

\begin{tabular}{ccrc}
\hline \hline Anos & Número AlH & Valor AlH & Valor Médio* \\
\hline 1994 & 10.606 & $11.080 .835,00$ & $1.044,00$ \\
1995 & 9.987 & $8.383 .058,00$ & 839,00 \\
1996 & 15.096 & $10.929 .763,00$ & 724,00 \\
1997 & 17.402 & $11.011 .270,00$ & 632,00 \\
1998 & 16.281 & $12.479 .664,00$ & 766,00 \\
1999 & 17.468 & $16.692 .561,00$ & 955,00 \\
2000 & 15.834 & $12.763 .657,00$ & 806,00 \\
\hline \hline
\end{tabular}

Fonte: Datasus/MS

* Valores em Real corrigidos a valores de dezembro de 2000 pelo Índice de Preços ao Consumidor Ampliado - IPCAVIBGE

Deve-se atentar ainda, para $\circ$ fato de que as $\mathrm{AlH}$ produzidas pelo $\mathrm{HC}$ tinham, até final de 2000 , acréscimo de $75 \%$ em seu valor devido ao Fator de Incentivo ao Desenvolvimento do Ensino e da Pesquisa em Saúde FIDEPS - pago pelo Ministério da Saúde aos hospitais universitários. A partir 
deste ano, os hospitais passaram a receber um valor fixo mensal, sendo que o $\mathrm{HC}$ recebeu naquele ano, 385 mil reais mensais como incentivo ao ensino e pesquisa em saúde.

Na Tabela 15 encontra-se o ranking dos dez procedimentos hospitalares mais freqüentes e de maior valor, realizados no HC entre 1994 a 2000. 
TABELA 15 - Ranking dos dez principais procedimentos realizados (freqüência e valor), Hospital das Clínicas da UFMG, 1994-2000

\begin{tabular}{|c|c|c|c|c|c|c|c|c|c|c|c|c|c|c|}
\hline \multicolumn{15}{|c|}{ ANOS } \\
\hline \multirow[t]{2}{*}{ Ranking } & \multicolumn{2}{|l|}{1994} & \multicolumn{2}{|c|}{1995} & \multicolumn{2}{|c|}{1996} & \multicolumn{2}{|c|}{1997} & \multicolumn{2}{|c|}{1998} & \multicolumn{2}{|c|}{1999} & \multicolumn{2}{|c|}{2000} \\
\hline & Freqüência & Valor & Freqüência & Valor & Freqüência & Valor & Freqüência & Valor & Freqüência & Valor & Freqüência & Valor & Freqüência & Valor \\
\hline Primeiro & $\therefore$ & FF & U & 0 & M & EE & M & DD & M & DD & M & DD & M & DD \\
\hline Segundo & D & $D$ & $\mathbf{N}$ & $\mathrm{FF}$ & 0 & 0 & $\therefore$ & 0 & $\therefore$ & $\mathrm{CC}$ & $\therefore$ & $\mathrm{CC}$ & U & CC \\
\hline Terceiro & $M$ & $\mathbf{F}$ & $\mathrm{L}$ & $\mathrm{U}$ & $\therefore$ & FF & 0 & $\mathrm{CC}$ & $\mathbf{N}$ & GG & $\mathbf{N}$ & $\underline{2}$ & $\therefore$ & GG \\
\hline Quarto & 0 & C & $C$ & D & D & $\mathrm{CC}$ & D & FF & D & D & D & V & $\mathbf{N}$ & V \\
\hline Quinto & $\underline{2}$ & $\mathrm{U}$ & $\mathbf{F}$ & $x$ & $\mathbf{N}$ & $D$ & $\mathbf{N}$ & (1) & 0 & 0 & $\mathbf{L}$ & $x$ & A & $\geq$ \\
\hline Sexto & $\mathbf{G}$ & 0 & $\mathrm{~S}$ & AA & $\mathbf{G}$ & $\mathrm{U}$ & I & U & I & $x$ & í. & FF & ts & BB \\
\hline Sétimo & $\mathbf{F}$ & $x$ & $\mathbf{J}$ & C & $\mathrm{L}$ & $x$ & $\mathbf{L}$ & 2 & $\mathbf{L}$ & U & 1 & $\mathrm{~S}$ & $\Xi$ & $\mathrm{S}$ \\
\hline Oitavo & $\mathbf{P}$ & 2 & $\therefore$ & G & $\mathbf{P}$ & C & $\mathbf{R}$ & $x$ & $R$ & $\geq$ & $\underline{2}$ & D & D & A \\
\hline Nono & is & $\mathbf{A A}$ & 0 & $\geq$ & í & $\rightleftarrows$ & $\mathbf{J}$ & $\mathbf{R}$ & G & $M$ & $\mathbf{Q}$ & $\mathbf{A A}$ & I & $x$ \\
\hline Décimo & $\mathrm{U}$ & $\mathbf{G}$ & $3 j$ & $\mathbf{H}$ & B & G & $\mathbf{Y}$ & M & $\mathbf{P}$ & C & $\Xi$ & C & $\mathbf{T}$ & E \\
\hline
\end{tabular}

\section{Fonte: Datasus/MS}

A. Acompanhamento Pós-Transplante de Rim, Figado etc

B. Apendicectomia

C. Artroplastia total do joelho (com implante)

Cesariana com atendimento RN sala de parto

E. Cesariana em gestante de alto risco

F. Cirurgia múltipla

G. Colecistectomia

H. Correção de cardiopatia congênita

I. Crise asmática

J. Crise hipertensiva

Curetagem pós-aborto

L. Diagnostico e/ou primeiro atendimento em clinica cirúrgica

M. Diagnostico e/ou primeiro atendimento em clinica medica

N. Diagnostico e/ou primeiro atendimento em clinica pediátrica

O. Facectomia com lente intra-ocular

P. Herniorrafia inguinal (unilateral)
R. Insuficiência cardíaca

S. Internação para quimioterapia de leucemias agudas (linfoides e não linfoides

T. Intercorrências clínicas de paciente oncológico

$\cup$. Leucemias agudas

V. Marca-passo cardiaco (intracavitario)

6arto Normal

Parto normal com atendimento RN sala de parto

Y. Pielonefrites

2. Prematuridade

AA. Septicemias (pediatria)

BB. Sindrome da API recém nascido (Membran Hialina)

CC. Transplante de fígado

DD. Transplante de medula alogenico aparentado

EE. Transplante de medula óssea

FF. Transplante renal receptor

GG. Transplante renal receptor (doador vivo) 
$\mathrm{Na}$ análise dos dez procedimentos hospitalares realizados com mais freqüência pelo HC para o SUS, no período estudado, notamos que, em 1994, eles representavam $31 \%(3.328 \mathrm{AlH})$ de todos os procedimentos feitos sob internação. Este percentual aumenta até 1997 para 41,75\% (7.265 AlH), quando começa a diminuir, voltando aos 33\% (5.295 AlH), em 2000. Em 1994 e 1995, os procedimentos "Parto normal com atendimento ao Recém nascido (RN) na sala de parto" ( ) e "Cesariana com atendimento RN na sala de parto" $(-)$ se destacam, como os de maior freqüência representando $14,89 \%$ e $13,53 \%$ de todas as internações, respectivamente. A partir de 1996, desde a implantação do pronto atendimento em urgência e emergência clínica no $\mathrm{HC}$, os procedimentos "Diagnóstico e/ou primeiro atendimento em clínica médica, pediatria e clínica cirúrgica" ( $L, M, N)$ vão se tornar os mais freqüentes, chegando a representar, em 1999, 21,15\% (3.695 $\mathrm{AlH})$ de todos os procedimentos hospitalares realizados no $\mathrm{HC}(17.468 \mathrm{AlH})$. No entanto, no ano de 2000 , os procedimentos de obstetrícia (parto normal e cesariana) retomam o primeiro lugar, representando $13,5 \%$ de todos os procedimentos realizados no Hospital das Clinicas.

Os dez procedimentos de maior faturamento representavam 34\%, em 1994, e $43 \%$, em 2000 , do valor total arrecado com a prestação de serviços ao SUS. Entre os procedimentos de maior faturamento, notamos que os de alto custo/complexidade se destacam como os "Transplantes (renal, medula óssea e fígado)" (CC, DD, EE, FF, GG) e o tratamento de "Leucemias agudas" (U) e a "Internação para quimioterapia de leucemias agudas" (S). Evidenciamos, também, a importância dos transplantes na economia do HC. 
O valor arrecadado pelos transplantes, em todos os anos estudados, foi da ordem de $20 \%$ do total recebido pelo HC com as internações para o SUS, chegando a representar, em $2000,28 \%$ do valor total das AlH pagas ao Hospital. Apesar da importância dos transplantes no faturamento, sua freqüência é menor do que $1 \%$ dos procedimentos realizados $(0,3 \%$ em 1994 e $0,7 \%$ em 2000). Entre os procedimentos de transplante, percebemos a perda gradativa de posição do "Transplante renal receptor" (FF) que, em 1994, era o transplante de maior faturamento no HC, caindo, em 1999, para a sexta posição. Apesar de ser o transplante mais antigo no $\mathrm{HC}$, vem perdendo posições, desde 1997, para o "Transplante de medula alogênico aparentado" (EE), o "Transplante de fígado" (CC) e o "Transplante renal receptor (doador vivo)" (GG). Dois outros procedimentos também são relevantes como receita do SUS: a "Cesariana com atendimento de RN na sala de parto" $(-)$ e a "Facectomia com lente intra-ocular" $(0)$. O primeiro está entre as quatro primeiras posições, tanto na freqüência quanto no valor, refletindo a posição do $\mathrm{HC}$ como referência para gestação de alto risco, o que é corroborado pela crescente importância do procedimento "Prematuridade" (-) entre os dez procedimentos de maior valor. A "Facectomia com lente intra-ocular" parece demonstrar a relevância da área de oftalmologia (Hospital São Geraldo) dentro do HC. Um aspecto que chama atenção, nesse procedimento, é o seu desaparecimento dentre os dez mais freqüentes e de maior valor no ano de 1999.

Observamos que não existe uma correlação muito estreita entre os procedimentos mais freqüentes e os de maior faturamento (Tabela 15). A 
"Cesariana com atendimento RN na sala de parto" $(\supset)$ " e "Parto normal com atendimento RN na sala de parto" ( foram os procedimentos que apareceram mais vezes tanto na freqüência como no valor (seis vezes). Em seguida vem a "Facectomia com lente intra-ocular" (0), com cinco vezes. Alguns procedimentos, ora são bastante freqüentes como as "Curetagens pós-aborto" ( ) (cinco vezes) e os "Diagnóstico e/ou primeiro atendimento em clínica médica" (L) (quatro vezes), mas não aparecem no ranking de valor, ora aparecem como os de maior valor, como o "Transplante renal receptor" (FF) e a "Artroplastia total do joelho" (C) (cinco vezes), mas não são visualizados nos dez mais freqüentes. Procedimentos como a "Prematuridade" ( ) e as "Leucemias agudas" (U) se distinguem mais pelo valor (seis e cinco vezes respectivamente) do que pela freqüência (três e duas vezes respectivamente). A "Colecistectomia" (G) se destaca por estar presente quatro vezes na freqüência e três no valor. Os demais procedimentos têm baixo aparecimento tanto na freqüência como no valor.

Em síntese poderiamos dizer, que de uma forma sutil o Hospital das Clínicas vem alterando seu mix de atendimentos. A partir de 1996, com a criação do Pronto Atendimento, notamos uma primazia dos procedimentos de urgência/emergência (Diagnóstico e/ou primeiro atendimento em clínica médica, pediatria e clínica cirúrgica), chegando a representar, em 1999, 21\% de todas as internações realizadas no $\mathrm{HC}$. Em relação aos procedimentos de maior valor, observamos uma consolidação dos transplantes. Outro dado que poderia corroborar a percepção de alteração do mix é a perda de importância, na freqüência e valor, do procedimento oftalmológico 
"Facectomia com lente intra-ocular". A partir de 1999 este procedimento deixa de estar entre os dez mais realizados no HC. Por sua vez, ocorre uma estabilização na posição dos procedimentos relacionados às "Leucemias agudas". Os procedimentos obstétricos - "Parto normal com atendimento RN na sala de parto" e "Cesariana com atendimento RN na sala de parto" - se destacam porque, durante o periodo estudado, estiveram sempre presentes, tanto na freqüência como no valor, representando cerca de $13,5 \%$ das $\mathrm{AlH}$ pagas ao $\mathrm{HC}$. Se considerarmos somente os dois últimos anos poderíamos dizer que, observando os dez principais procedimentos (freqüência e valor), o HC seria um hospital assentado em três grandes grupos de atendimentos hospitalares: os de urgência/emergência, os obstétricos e os transplantes.

A Tabela 16 apresenta os indicadores de produção ambulatorial para o SUS, freqüência e valor, total e desagregado, dos procedimentos. Notamos um crescimento da produção ambulatorial, ainda que em patamar menor do que o da internação. O número total de procedimentos ambulatoriais realizados pelo HC apresenta uma variação positiva de $28 \%$ entre 1994 e 2000 . Desagregando estes procedimentos observamos que as consultas médicas apresentam um crescimento de $14 \%$, os procedimentos de alto custo/complexidade de $26 \%$ e os procedimentos de patologia clínica de $67 \%$. Os atendimentos de urgência e emergência mostram incremento anual positivo, aumentando mais de dez vezes entre 1996 e 2000. Quando analisamos a variação do valor da produção ambulatorial do HC entre 1994 e 2000 , em real corrigido para valores de dezembro de 2000 , observamos queda no valor das consultas e aumento no dos outros procedimentos. 
Houve aumento de $33 \%$ no valor arrecadado pelo total de procedimentos ambulatoriais; de $40 \%$ no de alto custo/complexidade e de $39 \%$ nos exames de patologia clínica. Já as consultas médicas tiveram queda de $12 \%$ no seu valor. $E$ interessante destacar a não correlação entre freqüência e valor dos procedimentos ambulatoriais. Enquanto a participação dos procedimentos de alto custo/complexidade no número de procedimentos realizados girava em torno de $1,8 \%$ a $2,9 \%$, no valor esta participação vai variar de $27 \%$ a $47 \%$. As consultas que tinham participação de $26 \%$ a $30 \%$ no número total dos procedimentos ambulatoriais representam menos de $10 \%$ do valor. Os denominados procedimentos de apoio diagnóstico e terapêutico (exames de patologia clinica e alto custo/complexidade) vão representar de $58 \%$ a $72 \%$ de todo o valor arrecadado com procedimentos ambulatoriais.

Ao analisarmos a produção de serviços para o SUS, entre 1994 e 2000 , observamos que o crescimento da produção hospitalar é muito mais significativo no número de procedimentos produzidos do que no seu valor. Desta forma o número de internações realizadas cresce $49 \%$ e o montante arrecadado com as $\mathrm{AlH}$ apenas $15 \%$. O aumento da produção ambulatorial de $28 \%$ corresponde a um crescimento de $33 \%$ na receita. Portanto, os esforços para aumentar a produção hospitalar não têm correspondência proporcional no crescimento do valor recebido, e o aumento do montante recebido pela produção ambulatorial representa praticamente o seu incremento numérico. 
TABELA 16 - Frequeencia e valor dos procedimentos ambulatoriais do Hospital das Clinicas/UFMG, 1994-2000

\begin{tabular}{|c|c|c|c|c|c|c|c|c|}
\hline \multirow{3}{*}{ FreqüênciaNalor* } & \multicolumn{8}{|c|}{ ANOS } \\
\hline & \multicolumn{2}{|c|}{$1994^{\star *}$} & \multicolumn{2}{|c|}{1995} & \multicolumn{2}{|c|}{1996} & \multicolumn{2}{|c|}{1997} \\
\hline & Freqüência & Valor & Freqüência & Valor & Freqüência & Valor & Freqüência & Valor \\
\hline Consultas & 235.444 & $857.433,00$ & 216.953 & $654.501,00$ & 265.632 & $744.911,00$ & 260.863 & $705.440,00$ \\
\hline Alto Custo/Complexidade & 17.602 & $3.573 .100,00$ & 19.730 & $2.781 .188,00$ & 27.472 & $2.984 .120,00$ & 23.077 & $2.548 .949,00$ \\
\hline 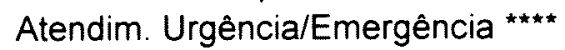 & - & - & - & - & 20.675 & $64.326,00$ & 45.473 & $135.579,00$ \\
\hline Exames de Patologia Clinica & 319.308 & $1.846 .776,00$ & 334.296 & $1.723 .573,00$ & 404.961 & $1.890 .972,00$ & 413.197 & $1.947 .586,00$ \\
\hline Total procedimentos & 811.752 & $7.896 .419,00$ & 820.682 & $6.613 .327,00$ & 934.940 & $7.018 .519,00$ & 892.974 & $6.342 .427,00$ \\
\hline
\end{tabular}

Fonte: Datasus/MS

* Valores em Real corrigidos a valores de dezembro de 2000 pelo Índice de Preços ao Consumidor Ampliado - IPCA/IBGE

** Os dados passaram a ser publicados, pelo Datasus, a partir de julho de 1994, os valores apresentados estão duplicados

*** A partir de 1998 estes procedimentos passaram a constituir o sistema de Autorização de Procedimentos de Alto Custo/Complexidade - APAC

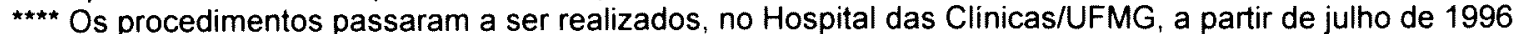

TABELA 16 - Freqüência e valor dos procedimentos ambulatoriais do Hospital das Clínicas/UFMG, 1994-2000 (continuação)

\begin{tabular}{|c|c|c|c|c|c|c|}
\hline \multirow{3}{*}{ Freqüência/Nalor ${ }^{\star}$} & \multicolumn{6}{|c|}{ ANOS } \\
\hline & \multicolumn{2}{|c|}{1998} & \multicolumn{2}{|c|}{1999} & \multicolumn{2}{|c|}{2000} \\
\hline & Freqüência & Valor & Freqüência & Valor & Freqüência & Valor \\
\hline Consultas & 282.930 & $822.141,00$ & 290.598 & $854.272,00$ & 268.852 & $754.352,00$ \\
\hline Alto Custo/Complexidade ${ }^{\star \star \star}$ & 15.279 & $2.032 .923,00$ & 19.378 & $3.376 .832,00$ & 22.211 & $4.996 .590,00$ \\
\hline Atendim. Urgência/Emergência ${ }^{\star \star \star \star}$ & 67.740 & $219.875,00$ & 64.683 & $222.810,00$ & 237.266 & $660.934,00$ \\
\hline Exames de Patologia Clinica & 395.974 & $2.272 .783,00$ & 509.230 & $2.577 .819,00$ & 532.851 & $2.579 .481,00$ \\
\hline Total procedimentos & 917.340 & $7.406 .169,00$ & 1.060 .432 & $9.767 .731,00$ & 1.038 .656 & $10.471 .087,00$ \\
\hline
\end{tabular}

Total procedimentos

Fonte: Datasus/MS

* Valores em Real corrigidos a valores de dezembro de 2000 pelo Índice de Preços ao Consumidor Ampliado - IPCA/IBGE

** Os dados passaram a ser publicados, pelo Datasus, a partir de julho de 1994, os valores apresentados estão duplicados

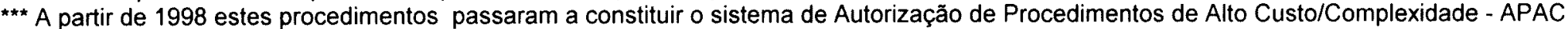

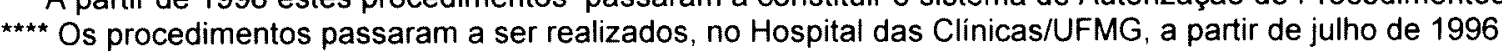


A participação do $\mathrm{HC}$ no número e valor das $\mathrm{AlH}$ e dos procedimentos ambulatoriais realizados em Belo Horizonte, entre 1994-2000, é apresentada na Tabela 17. Quando comparamos a participação do HC no total de internações realizadas pelo SUS, em $\mathrm{BH}$, podemos ver que há um crescimento constante, novamente mais expressivo em relação ao número $(86 \%)$ do que no valor das $\mathrm{AlH}$ (44\%). É importante destacar que neste período, houve uma queda de $20 \%$ no número e valor das $\mathrm{AlH}$ produzidas e pagas no Município (de 297 mil para 239 mil AlH e de 172 milhões para 140 milhões de reais). Podemos dizer que o crescimento da participação do Hospital das Clínicas no "mercado público" de prestação de serviços de internação em Belo Horizonte ocorreu num ambiente de racionalização. Em relação à participação do HC na produção ambulatorial do SUS, podemos observar que houve um aumento de $31 \%$ na participação no número total de procedimentos ambulatoriais $(20 \%$ no valor), com crescimento de $60 \%$ no número de consultas médicas e de $58 \%$ no de procedimentos de patologia clínica ( $67 \%$ e $43 \%$ respectivamente no valor). Mais expressiva foi a participação do $\mathrm{HC}$ no total de atendimentos de urgência/emergência realizados em $\mathrm{BH}$, aumentando quase cinco vezes (quatro vezes no valor), entre 1996 e 2000. Já para os procedimentos de alto custo/complexidade houve queda acentuada da participação do HC no número total de procedimentos realizados (e redução de $25 \%$ no valor), especialmente nos dois últimos anos. Novamente é importante destacar que também ocorreu redução do número e valor dos procedimentos ambulatoriais em Belo Horizonte no periodo estudado, com exceção dos procedimentos de alto custo/complexidade e de urgência e emergência. 
TABELA 17 - Participação, em percentual, do Hospital das Clínicas/UFMG na freqüência e valor das AlH e dos procedimentos ambulatoriais realizados em Belo Horizonte, 1994-2000

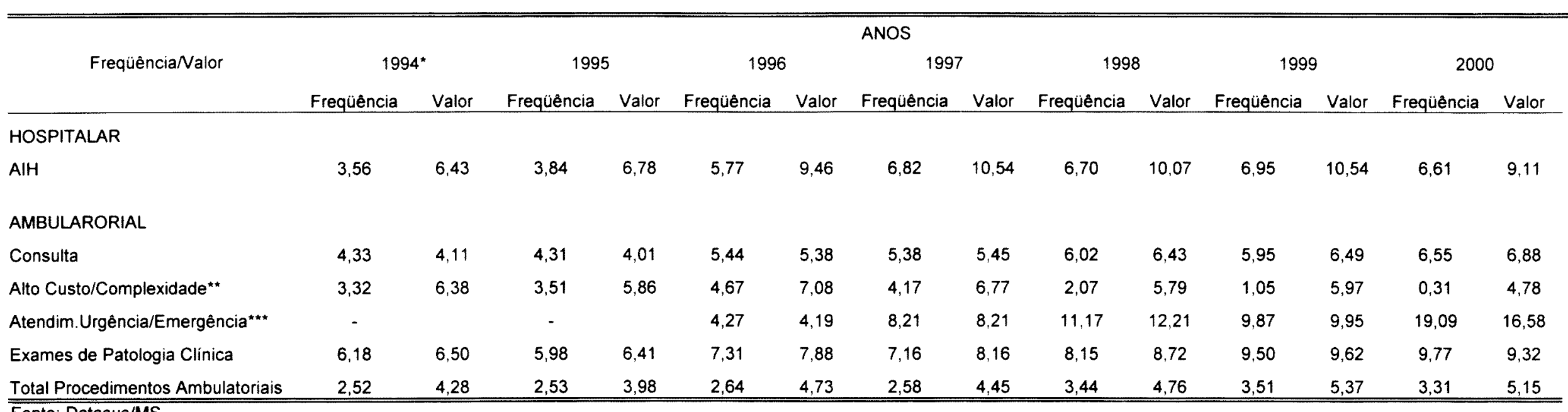

Fonte: Datasus/MS

" Os dados passaram a ser publicados, pelo Datasus, a partir de julho de 1994, os valores apresentados estão duplicados

* A partir de 1998 os dados sobre procedimentos de alto custo/complexidade passaram a ser denominados Autorização de Procedimentos de Alto Custo/Complexidade - APAC

*** Os procedimentos passaram a ser realizados, no Hospital das Clínicas/UFMG, a partir de julho de 1996 
A Tabela 18 mostra a freqüência e valor dos serviços de internação e atendimento ambulatorial prestados a convênios e particulares pelo Hospital das Clínicas/UFMG, entre $1994-2000^{28}$.

TABELA - 18 Número de pacientes (internados ou atendimentos externos) e valor pago por Convênios e Particular, Hospital das Clínicas/UFMG, 1996-2000*

\begin{tabular}{ccccccc}
\hline \multirow{2}{*}{ Ano } & \multicolumn{2}{c}{ Particular } & \multicolumn{2}{c}{ Convênios } & \multicolumn{2}{c}{ Total } \\
& Freqüéncia & Valor & Freqüencia & Valor & Freqüencia & Valor \\
\hline 1996 & - & $1.112 .824,00$ & - & $486.387,00$ & - & $1.599 .212,00$ \\
1997 & 2.469 & $1.076 .258,00$ & 1.072 & $823.576,00$ & 3.541 & $1.899 .834,00$ \\
1998 & 2.213 & $936.422,00$ & 5.990 & $1.968 .153,00$ & 8.203 & $2.904 .575,00$ \\
1999 & 1.511 & $878.432,00$ & 10.186 & $3.148 .940,00$ & 11.697 & $4.027 .373,00$ \\
2000 & 2.225 & $798.072,00$ & 4.845 & $4.726 .488,00$ & 7.070 & $5.524 .561,00$ \\
\hline \hline
\end{tabular}

Fonte: Divisão Financeira e Seção de Convênios do Hospital das Clínicas/UFMG

* Valores em Real corrigidos a valores de dezembro de 2000 pelo Índice de Preços ao Consumidor Ampliado - IPCA/IBGE

Destacamos o crescimento constante da receita dos convênios, que representava, em 1996, 30\% do somatório destas duas fontes e $85 \%$ em 2000. Dentre os convênios com planos de saúde o da UNIMED/BH se destaca. Em 1997, este plano representava, na prestação de serviços para planos de saúde, $43 \%$ do número de pacientes internados e $29 \%$ do valor arrecadado e, em 2000 , alcançava $65 \%$ e $58 \%$, respectivamente. No entanto, é interessante destacar a pequena participação do Hospital das Clínicas no conjunto de hospitais e serviços ambulatoriais que atendem pacientes da UNIMED/BH. Segundo dados desta cooperativa, em 1999 e 2000, a participação do Hospital das Clínicas no total de suas despesas e no número de internações hospitalares era de apenas $2 \%$. No setor ambulatorial, em 1999 a participação

\footnotetext{
${ }^{28}$ Dados mais detalhados sobre convênios com planos de saúde e atendimento de paciente com desembolso direto (particulares) só estão disponiveis a partir de 1997, quando foi criada a Seção de Convênios.
} 
do Hospital das Clínicas representava apenas $1 \%$ das despesas ambulatoriais e menos de $0,5 \%$ dos atendimentos. No ano de 2000 , apesar de manter o mesmo percentual para a quantidade de atendimentos realizado, estes alcançaram cerca de $4 \%$ das despesas da UNIMED/BH com os serviços ambulatoriais.

A Tabela 19 apresenta as despesas, no total e por item, e a Tabela 20 apresenta a variação do valor (em real corrigido para dezembro de 2000) das despesas, por item e total, tendo como base o ano de 1994. As despesas apresentam crescimento, com um único ponto de inflexão, em 1998, saindo de um patamar de despesas em torno de 24 milhões de reais em 1994, alcança 38 milhões no ano 2000 , um crescimento em cerca de $58 \%$ entre estes anos. Quando analisamos os itens que compõem as despesas, percebemos que 0 material de consumo é sempre o item de maior peso, representando de $33 \%$ a 39\% (1994 e 1999 respectivamente), do valor total das despesas do HC. Apesar de representar uma variação positiva de $76 \%$ entre 1994 e 2000 , notamos uma estabilidade do gastos com material de consumo até 1998 , voltando a crescer nos dois últimos anos. A despesa com a contratação de pessoal através da Fundação de Desenvolvimento de Pesquisa (FUNDEP) é o segundo item em importância, variando de 31\%, em 1994 a 19\% em 2000 do valor total das despesas. No entanto, houve uma variação negativa desse item de despesa de $7 \%$ no período estudado, era de 7,5 milhões de reais no ano de 1994 e pouco mais de 7 milhões, em 2000. Um item tem se destacado pelo seu crescimento contínuo: o pagamento de plantōes médicos. Esta despesa representava, em 1994, 2,6\% do total, passando para 13\% em 2000. Era de 
623 mil reais, no primeiro ano do estudo subindo para 5,1 milhões de reais, no último. Se agruparmos as despesas referentes ao pagamento de pessoal (FUNDEP, plantões e serviços profissionais) ${ }^{29}$, este passa a ser o principal item de despesas ficando em torno de $36 \%$ (14 milhões de reais) em 2000. As despesas com os denominados outros serviços, especialmente os serviços públicos (água, luz, telefone etc) também é um item que vem crescendo, mais do que duplicando seu valor entre os anos estudados. Ademais sempre foram uma despesa que ficou acima dos $10 \%$, significando, em 2000 , cerca de 6,3 milhões de reais $(16 \%)$, ocupando o terceiro lugar. Chama atenção, o item material permanente por ser o de menor participação no total das despesas, apesar de crescer $50 \%$ nos anos considerados. Essa despesa correspondeu a $0,6 \%$ do total gasto em $1997,5,2 \%$ em 1996, não chegando a $2 \%$ no ano 2000 . As despesas com higiene e limpeza permanecem, sem grandes variações nestes anos, ao redor de $5 \%$, mesmo tendo crescido $22 \%$ no periodo. As despesas com a prestação de serviços pela Fundação Mendes Pimentel para o fornecimento de gêneros alimentícios, dietas industrializadas, formas lácteas e embalagens vem diminuindo, apresentando incremento negativo de $34 \%$. Representava em $2000(3,2 \%)$ menos da metade do percentual referente a $1994(7,9 \%)$.

\footnotetext{
${ }^{29}$ Serviços Profissionais: em 1992, foi introduzido o pagamento dos serviços profissionais (SP) aos professores da Faculdade de Medicina/UFMG, que exercem atividade assistencial no HC. O repasse do $\mathrm{SP}$ aos docentes é feito mensalmente, num valor que corresponde a $70 \%$ sobre a parcela referente ao SP da Tabela do SUS.
} 
TABELA 19 - Despesas totais em Real corrigido para valores de dezembro de 2000, Hospital das Clínicas/UFMG, 1994-2000*

\begin{tabular}{|c|c|c|c|c|c|c|c|}
\hline \multirow{2}{*}{ Item Despesa } & \multicolumn{7}{|c|}{ ANOS } \\
\hline & 1994 & 1995 & 1996 & 1997 & 1998 & 1999 & 2000 \\
\hline Pessoal (FUNDEP) & 7.573 .220 .00 & $4.934 .821,00$ & $7.597 .353,00$ & $8.155 .689,00$ & $5.638 .002,00$ & $5.728 .644,00$ & $7.045 .435,00$ \\
\hline Plantőes & $623.697,00$ & $1.653 .148,00$ & $2.924 .470,00$ & $4.436 .369,00$ & $4.275 .385,00$ & $4.454 .111,00$ & $5.144 .316,00$ \\
\hline Serviços Profissionais & $1.543 .152,00$ & $1.632 .390,00$ & $1.197 .658,00$ & $769.606,00$ & $1.440 .493,00$ & $1.761 .197,00$ & $1.813 .686,00$ \\
\hline Alimentação (FUMP) & $1.904 .491,00$ & $1.387 .085,00$ & $1.203 .561,00$ & $1.021 .319,00$ & $805.790,00$ & $1.156 .989,00$ & $1.223 .468,00$ \\
\hline Outros Serviços ${ }^{\star \star}$ & $2.648 .729,00$ & $3.118 .536,00$ & $3.031 .312,00$ & $3.453 .624,00$ & $3.786 .130,00$ & $4.381 .055,00$ & $6.348 .687,00$ \\
\hline Higiene e Limpeza & $1.358 .141,00$ & $1.737 .288,00$ & $1.824 .233,00$ & $1.889 .150,00$ & $1.685 .930,00$ & $1.661 .065,00$ & $1.654 .930,00$ \\
\hline Material Permanente & $454.457,00$ & $496.550,00$ & $1.513 .324,00$ & $193.693,00$ & $540.545,00$ & $675.457,00$ & $696.210,00$ \\
\hline Material Consumo & $8.050 .110,00$ & $9.714 .820,00$ & $10.254 .389,00$ & $10.467 .656,00$ & $10.605 .842,00$ & $13.160 .978,00$ & $14.219 .415,00$ \\
\hline Total & 24.156 .001 .00 & $24.674 .643,00$ & $29.546 .303,00$ & $30.387 .110,00$ & $28.778 .121,00$ & $32.979 .499,00$ & $38.146 .149,00$ \\
\hline
\end{tabular}

Fonte: Divisâo Financeira do Hospital das Clinicas/UFMG

* Valores em Real corrigidos pelo Indice de Preços ao Consumidor Ampliado - IPCAIBGE

** Outros Servicos: contratos e outros serviços sem contratos (Telemig, Cemig, Copasa, Cruz Vermelha, Sup. Fundos

reprografia inscriçøes de cursos, diárias, passagens, exp. motivos, SLU, Despesas alfandegárias,BL 02, Exames NUPAD)

TABELA 20 - Variação do valor das despesas, por item e total, Hospital das Clinicas/UFMG, 1994-2000, ANO BASE $1994=100$

\begin{tabular}{|c|c|c|c|c|c|c|c|}
\hline \multirow{2}{*}{ Item Despesa } & \multicolumn{7}{|c|}{ ANOS } \\
\hline & 1994 & 1995 & 1996 & 1997 & 1998 & 1999 & 2000 \\
\hline Pessoal (FUNDEP) & 100 & 65 & 100 & 108 & 74 & 76 & 93 \\
\hline Plantőes & 100 & 265 & 469 & 711 & 685 & 714 & 825 \\
\hline Serviços Profissionais & 100 & 106 & 78 & 50 & 93 & 114 & 118 \\
\hline Alimentação (FUMP) & 100 & 73 & 63 & 54 & 42 & 61 & 64 \\
\hline Outros Serviços ${ }^{\star \star}$ & 100 & 118 & 114 & 130 & 143 & 165 & 240 \\
\hline Higiene e Limpeza & 100 & 128 & 134 & 139 & 124 & 122 & 122 \\
\hline Material Permanente & 100 & 109 & 333 & 43 & 119 & 149 & 153 \\
\hline Material Consumo & 100 & 121 & 127 & 130 & 132 & 163 & 177 \\
\hline Total & 100 & 102 & 122 & 126 & 119 & 137 & 158 \\
\hline
\end{tabular}

Fonte: Divisăo Financeira do Hospital das Clinicas/UFMG

* Outros Serviços: contratos e outros serviços sem contratos (Telemig, Cemig, Copasa, Cruz Vermelha, Sup. Fundos

reprografia, inscriçðes de cursos, diárias, passagens, exp. motivos, SLU, Despesas alfandegárias, BL 02, Exames NUPAD) 
A arrecadação total, as despesas e os deficit ou superavit estão representados na Tabela 21. Quando consideramos os recursos arrecadados com a prestação de serviços, com convênios com órgãos públicos e outros (arrecadação total), veremos que a partir de 1997 ocorre um superavit, que é bastante expressivo naquele ano (2,2 milhões de reais), caindo nos anos subseqüentes sendo de 227 mil em 2000. Entretanto, este superavit pode ser aparente, pois a utilização dos recursos captados nos convênios com órgãos públicos vem, em muitos casos, predefinido (compra de equipamentos e/ou readequação de áreas fisicas) não se permitindo seu uso para custeio. É interessante notar que, entre 1994 e 2000, a arrecadação mais que dobrou enquanto que as despesas aumentaram em $58 \%$. No entanto, observamos um deficit constante nas contas do $\mathrm{HC}$ ao comparamos sua arrecadação advinda da prestação de serviços (SUS, Convênios/particulares) com as despesas, mesmo desconsiderando as despesas com pessoal, pagas pelo MEC e serviço de vigilância, pago pela UFMG. Notamos, também, que este deficit vem diminuindo ano a ano, situando-se em torno dos 7 milhões de reais até 1996, caindo entre 1997 a 1999, mas voltando a crescer em 2000. A arrecadação proveniente da prestação de serviços cobria $67 \%$ das despesas do $\mathrm{HC}$ em 1994, aumentando para $88 \%$ em 2000 . 
TABELA 21 - Arrecadação com a prestação de serviços e total, despesas, deficit ou superavit, Hospital das Clinicas/UFMG, 1994-2000*

\begin{tabular}{lccccccc}
\hline \hline & \multicolumn{5}{c}{ ANOS } & & \\
& 1994 & 1995 & 1996 & 1997 & 1998 & 1999 & 2000 \\
\hline Arrecadação Total & $16.218 .466,44$ & $17.083 .903,79$ & $27.890 .600,22$ & $32.657 .224,04$ & $29.745 .763,41$ & $33.192 .035,42$ & $38.373 .479,34$ \\
Despesas & $24.156 .001,42$ & $24.674 .643,13$ & $29.546 .303,18$ & $30.387 .110,38$ & $28.778 .121,39$ & $32.979 .499,23$ & $38.146 .149,99$ \\
Deficit/Superavit & $(7.937 .534,98)$ & $(7.590 .739,34)$ & $(1.655 .702,96)$ & $2.270 .113,66$ & $967.642,02$ & $212.536,19$ & $227.329,35$ \\
& & & & & & & \\
Arrecadação Prest.Serv. & $16.218 .466,44$ & $17.083 .903,79$ & $22.202 .381,22$ & $24.707 .937,04$ & $25.270 .967,41$ & $29.719 .498,42$ & $33.564 .454,34$ \\
Despesas & $24.156 .001,42$ & $24.674 .643,13$ & $29.546 .303,18$ & $30.387 .110,38$ & $28.778 .121,39$ & $32.979 .499,23$ & $38.146 .149,99$ \\
Deficit/Supervit & $(7.937 .534,98)$ & $(7.590 .739,34)$ & $(7.343 .921,96)$ & $(5.679 .173,34)$ & $(3.507 .153,98)$ & $(3.260 .000,81)$ & $(4.581 .695,65)$ \\
\hline \hline
\end{tabular}

Fonte: Divisão Financeira do Hospital das Clínicas/UFMG

* Valores em Real corrigidos pelo Indice de Preços ao Consumidor Ampliado - IPCA/IBGE 
Na Tabela 22 onde é apresentada a relação entre despesas com pessoal e material de consumo e arrecadação do $\mathrm{HC}$, observamos que apenas dois itens de despesas, material de consumo e pagamento de pessoal (contratados, RPA e serviços profissionais) consomem a quase totalidade da arrecadação total, representando, em 1994 mais de 100\%, ficando na casa dos $70 \%$ nos outros anos (em 2000 cerca de $73 \%$ ). O percentual consumido com estes itens vem caindo, especialmente 0 com pessoal, que representava em 1994, 60\% do arrecadado passando para 36\%, em 2000 . Se considerarmos, apenas o arrecadado com a prestação de serviços percebemos a mesma tendência de queda da participação desses dois itens de despesas no comprometimento da arrecadação.

TABELA 22 - Percentual dos itens de despesa gastos com pessoal e material de consumo, na arrecadação total e na de prestação de serviços, Hospital das Clínicas da UFMG, 1994-2000

\begin{tabular}{lrrrrrrr}
\hline \multicolumn{1}{c}{ Pessoal-Material/Arrecadaçăo } & \multicolumn{7}{c}{ ANOS } \\
& 1994 & 1995 & 1996 & 1997 & 1998 & 1999 & 2000 \\
\hline Pessoal/Arrecadação Total & 60,06 & 48,12 & 42,02 & 40,91 & 38,17 & 35,98 & 36,49 \\
Pessoal/Arrecadação Prest.Serviço & 60,06 & 48,12 & 52,78 & 54,08 & 44,93 & 40,19 & 41,72 \\
& & & & & & & \\
Mat. Consumo/Arrecadação Total & 49,64 & 56,87 & 36,77 & 32,05 & 35,65 & 39,65 & 37,06 \\
Mat. Consumo/Arrec. Prest.Serviço & 49,64 & 56,87 & 46,19 & 42,37 & 41,97 & 44,28 & 42,36 \\
& & & & & & & \\
Pessoal + Mat. Cons./Arrec. Total & 109,69 & 104,98 & 79,00 & 72,97 & 73,82 & 75,64 & 73,55 \\
$\begin{array}{l}\text { Pessoal + Mat. Cons./Arrec. } \\
\text { Prest.Serviço }\end{array}$ & 109,69 & 104,98 & 98,97 & 96,44 & 86,90 & 84,47 & 84,09 \\
\hline \hline
\end{tabular}

Fonte: Divisão Financeira do Hospital das Clínicas/UFMG 
Os indicadores de produtividade da capacidade instalada são apresentados na Tabela 23.

TABELA 23 - Indicadores de produtividade da Capacidade Instalada, Hospital das Clínicas/UFMG, 1994-2000*

\begin{tabular}{lccccccc}
\hline \multicolumn{1}{c}{ INDICADOR } & 1994 & 1995 & 1996 & 1997 & 1998 & 1999 & 2000 \\
\hline Leitos Disponiveis & 340 & 357 & 351 & 266 & 296 & 309 & 385 \\
N $^{*}$ AlH/Leito Disponivel & 31 & 27 & 43 & 65 & 55 & 56 & 41 \\
Valor AlH/Leito Disponivel $^{\star}$ & $32.590,00$ & $23.482,00$ & $31.139,00$ & $41.395,00$ & $42.161,00$ & $54.021,00$ & $33.152,00$ \\
\hline \hline
\end{tabular}

Fonte: Datasus/MS e SAME do Hospital das Clínicas/UFMG

* Valores em Real corrigidos a valores de dezembro de 2000 pelo Indice de Preços ao Consumidor Ampliado - IPCA/IBGE

Observamos quedas e pequenas recuperações do número de leitos desde 1994, sendo que em 2000 esse número é $13 \%$ maior do que no início de nossa análise, respectivamente 340 e 385 leitos. Notamos melhoria dos indicadores de capacidade instalada, com crescimento tanto do número como do valor de AlH por leito disponivel até 1999. Em 2000 observamos queda destes dois indicadores, ainda que tenha ocorrido uma variação positiva de $32 \%$ no número (31 AlH/leito para $41 \mathrm{AlH} /$ leito) e praticamente o mesmo valor de AlH por leito disponível (33 mil reais/leito), entre 1994 e 2000. As oscilações observadas estariam mais relacionadas ao aumento e queda da produção de serviços para o SUS ocorridos no periodo do que alterações no número de leitos. Devemos atentar que até $30 \%$ dos leitos podem ser utilizados para o atendimento de clientela de convênios/particular.

Os indicadores de produtividade dos recursos humanos são mostrados na Tabela 24. Nessa análise somente foram considerados, para cálculo da produtividade, os profissionais que apresentam vínculos contratuais, formais ou informais, ou estão lotados diretamente no Hospital das Clínicas. Assim, 
não foram considerados os professores e alunos, apesar de se saber de suas contribuições para a produção do hospital, mas consideramos os médicos residentes, que tem um número fixo de bolsas alocadas pelo MEC no HC. O número de Recursos Humanos apresenta ligeiras variações, destacando um pico de crescimento em 1996 (incremento de $15 \%$ em relação ao anterior) e outro de queda (cerca de 10\%) entre este ano e 1997. Houve um aumento de $12 \%$ no número de $\mathrm{RH}$ entre o primeiro e o último ano estudado. Observamos que a produtividade dos trabalhadores do HC aumentou somente no número de internações $(33 \%)$, pois no setor ambulatorial praticamente acompanhou o crescimento da força de trabalho (14\%), entre 2000 e 1994. É interessante notar que $O$ aumento da produtividade na internação ocorreu sem que houvesse alteração no número de $\mathrm{RH}$ por leito disponível.

TABELA 24 - Recursos humanos: número e produtividade, Hospital das Clínicas/UFMG, 1994-2000

\begin{tabular}{lrrrrrrr}
\hline \multicolumn{1}{c}{$\begin{array}{c}\text { Número de RH/ } \\
\text { Indicadores }\end{array}$} & 1994 & 1995 & 1996 & 1997 & 1998 & 1999 & 2000 \\
\hline Número de RH & 2.483 & 2.444 & 2.818 & 2.547 & 2.626 & 2.744 & 2.786 \\
Número AlH/RH & 4,27 & 4,09 & 5,36 & 6,83 & 6,20 & 6,37 & 5,68 \\
Valor AlH/RH* & $4.462,00$ & $3.430,00$ & $3.878,00$ & $4.323,00$ & $4.752,00$ & $6.083,00$ & $4.581,00$ \\
Produçắ AmbulatoriaVRH & 326,92 & 335,79 & 331,77 & 350,60 & 349,33 & 386,45 & 372,81 \\
Valor ProduçáoAmbuV/RH* & $3.180,00$ & $2.705,00$ & $2.490,00$ & $2.490,00$ & $2.820,00$ & $3.559,00$ & $3.758,00$ \\
RH/Leito disponiveVano & 7,30 & 6,85 & 8,03 & 9,58 & 8,87 & 8,88 & 7,24 \\
\hline \hline
\end{tabular}

Fonte: DATASUS, SAME e Divisão de Recursos Humanos do Hospital das Clinicas/UFMG

- Valores em Real corrigidos a valores de dezembro de 2000 pelo Indice de Preços ao Consumidor Ampliado - IPCAIIBGE

É importante destacar o expressivo número de entidades contratantes e formas institucionais de vinculação dos recursos humanos dentro do $\mathrm{HC}$. A Fundação Mendes Pimentel e a Cruz Vermelha brasileira pagam os bolsistas, a FUNDEP paga os contratados celetistas, e os que recebem 
através de recibo de pagamento de autônomo (RPA), principalmente médicos, por meio de sua cooperativa de trabalho, a HCCOOP. Atualmente, a FUNDEP também, intermedia contrato de trabalho para o $\mathrm{HC}$ através de sua própria cooperativa: a MULTICOOP. Dentre os órgãos públicos vamos encontrar o Ministério da Educação que paga os servidores estatutários da UFMG lotado no Hospital e a bolsa dos médicos residentes; além de profissionais de outras universidades à disposição do HC. Temos ainda, a Secretaria de Saúde de Minas Gerais, prefeituras e outros órgãos federais que, em casos especiais, cederam trabalhadores para o HC (são os denominados disponibilizados).

A média de permanência nos leitos do $\mathrm{HC}$ e de clínicas selecionadas é apresentada na Tabela 25.

TABELA 25 - Média de Permanéncia por Clínica e Geral, em dias, Hospital das Clínicas, 1994-2000

\begin{tabular}{lrrrrrrr}
\hline \multirow{2}{*}{ Clinicas Selecionadas/Geral } & \multicolumn{7}{c}{ ANOS } \\
& 1994 & 1995 & 1996 & 1997 & 1998 & 1999 & 2000 \\
\hline Clínica Médica & 13,93 & 15,35 & 12,40 & 16,79 & 16,11 & 16,23 & 16,50 \\
Clínica Cirúgica & 5,35 & 5,17 & 5,21 & 4,56 & 4,60 & 5,05 & 4,20 \\
Clínica Pediátrica & 13,07 & 11,53 & 12,20 & 12,31 & 9,74 & 7,04 & 7,90 \\
Clínica Ginecológica & 5,60 & 5,69 & 5,80 & 4,32 & 5,13 & 4,04 & 4,30 \\
Clínica Obstétrica & 3,48 & 4,00 & 3,50 & 3,35 & 3,18 & 3,30 & 3,00 \\
UTI Adulto & 3,01 & 3,51 & 4,21 & 4,47 & 5,64 & 4,91 & 4,90 \\
UTI Pediátrico & 6,80 & 7,02 & 8,43 & 7,99 & 8,65 & 9,30 & 11,50 \\
UTI Neo Natal e Berçário* & 11,98 & 13,25 & 11,64 & 11,22 & 11,11 & 6,44 & 11,90 \\
Geral & 7,79 & 7,67 & 7,48 & 6,81 & 6,06 & 5,88 & 5,56 \\
\hline \hline
\end{tabular}

Fonte: SAME/HC/UFMG

^Em 1997, o berçário passou a ser projeto Canguru

Houve queda constante da média de permanência no HC nos anos analisados, com redução de $29 \%$ do tempo de permanência. Entre as 
clínicas observamos grande variação: das clínicas básicas, a clínica médica apresenta as maiores médias, com crescimento de $18 \%$ entre 1994 e 2000 , abaixo, no entanto, do expressivo crescimento da média de permanência das UTI, adulto e pediátrico, de $63 \%$ e $69 \%$, passando de 3 dias para 11 dias nas duas unidades. As outras clínicas apresentaram queda em suas médias de permanência, com destaque para a clínica pediátrica que, em 1994, era de 13 dias passando para 7,9 dias em 2000 (queda de 40\%).

A taxa de ocupação dos leitos do HC é mostrada na Tabela 26.

TABELA 26 - Taxa de Ocupação por Clínica e Geral (\%), Hospital das Clínicas, 1994-2000

\begin{tabular}{lccccccc}
\hline \multicolumn{1}{c}{ Clínicas Selecionadas/Geral } & \multicolumn{7}{c}{ ANOS } \\
& 1994 & 1995 & 1996 & 1997 & 1998 & 1999 & 2000 \\
\hline Clínica Médica & 83,70 & 88,29 & 85,95 & 84,65 & 90,32 & 92,83 & 90,50 \\
Clínica Cirúgica & 64,47 & 67,08 & 65,74 & 60,16 & 59,51 & 62,68 & 63,80 \\
Clinica Pediátrica & 85,53 & 92,69 & 93,70 & 90,02 & 85,06 & 81,16 & 80,90 \\
Clínica Ginecológica & 49,89 & 52,82 & 62,34 & 80,23 & 83,18 & 75,66 & 76,00 \\
Clínica Obstétrica & 62,89 & 71,57 & 76,52 & 63,40 & 61,80 & 75,50 & 81,90 \\
UTI Adulto & 57,94 & 72,22 & 89,53 & 99,37 & 88,53 & 67,61 & 56,30 \\
UTI Pediátrico & 91,96 & 80,30 & 126,78 & 153,25 & 91,90 & 94,22 & 97,00 \\
UTI Neo Natal e Berçário* & 74,60 & 99,86 & 88,01 & 75,48 & 73,29 & 50,45 & 71,80 \\
Geral & 70,80 & 74,24 & 74,78 & 69,36 & 67,29 & 73,13 & 72,95 \\
\hline \hline
\end{tabular}

Fonte: SAME/HC/UFMG

`Em 1997, o berçário passou a ser projeto Canguru

A taxa de ocupação nos leitos do HC está em torno de $70 \%$, registrando em 1996 sua maior taxa de ocupação (75\%). O comportamento desta taxa variou bastante entre as clínicas. A clínica cirúrgica (59\%), ginecológica (50\%) e a UTI adulto (56\%) apresentaram os menores taxas durante o período, enquanto que a UTI pediátrico mostrou em dois momentos taxas superiores a $100 \%(127 \%$ em 1996 e $153 \%$ em 1997). Ao compararmos as 
taxas entre os anos de 1994 e 2000 , notamos um crescimento de $52 \%$ na taxa de ocupação na clinica ginecológica; de $30 \%$ na obstétrica; e de apenas $8 \%$ na clínica médica, enquanto as demais clínicas tiveram queda em sua taxa de ocupação (1\% a 4\%).

A taxa de infecção do HC é apresentada na Tabela 27. Ocorreu queda continua da taxa de infecção caindo para menos da metade em 2000 em relação a 1994 (de 12,9\% para 5,8\%). A alta taxa de infeç̧ão apresentada pela clínica pediátrica nos dois primeiros anos causou-nos estranheza uma vez que cai abruptamente nos anos posteriores (queda de 93\%). Chama também atenção a queda de $60 \%$ na Clínica médica e de $40 \%$ na UTI pediátrico e na clínica obstétrica. No entanto, a UTI adulto e clínica cirúrgica apresentaram aumento de suas taxas, $80 \%$ e $60 \%$ respectivamente, entre 1994 e 2000.

TABELA 27 - Taxa de Infecção por Clínica e Geral, Hospital das Clinicas (\%), 1994-2000

\begin{tabular}{lrrrrrrr}
\hline \multicolumn{1}{c}{ Clínicas Selecionadas/Geral } & \multicolumn{7}{c}{ ANOS } \\
& 1994 & 1995 & 1996 & 1997 & 1998 & 1999 & 2000 \\
\hline Clinica Médica & 12,89 & 2,35 & 3,99 & 2,03 & 9,76 & 2,10 & 5,20 \\
Clínica Cirúrgica & 5,74 & 6,85 & 4,96 & 5,78 & 4,98 & 8,39 & 9,20 \\
Clínica Pediátrica & 29,21 & 23,13 & 5,17 & 2,31 & 9,92 & 1,24 & 2,10 \\
Clínica Ginecológica & 6,95 & 7,45 & 3,45 & 0,76 & 0,91 & 1,48 & 5,50 \\
Clínica Obstétrica & 2,17 & 4,74 & 2,00 & 1,22 & 0,00 & 0,00 & 1,30 \\
UTI Adulto* & 18,88 & 17,16 & 23,07 & 8,54 & 28,20 & 32,92 & 34,00 \\
UTI Pediátrico* & 18,88 & 17,16 & 23,07 & 8,54 & 28,20 & 32,92 & 11,40 \\
UTI Neo Natal e Berçário** & 45,47 & 46,31 & 35,43 & 37,74 & 32,74 & 46,60 & 40,60 \\
Geral & 12,77 & 12,03 & 7,37 & 6,97 & 6,21 & 5,93 & 5,80 \\
\hline \hline
\end{tabular}

Fonte: SAME/HC/UFMG

* UTI Adulto e Pediátrico estavam juntos até 1999

** Em 1997, o berçário passou a ser projeto Canguru 


\subsection{PERCEPÇÃO, INCORPORAÇÃO, RESISTÊNCIA E REDEFINIÇÃO DO CONCEITO DE EFICIENCIA PELOS TRABALHADORES E GERÊNCIA.}

\subsubsection{Percepção, incorporação, resistência e redefinição do conceito de eficiência pelos trabalhadores}

A maioria dos trabalhadores do $\mathrm{HC}$ relata ter conhecimento pouco aprofundado sobre a reforma do Estado. As propostas de autonomia universitária e de transformação dos hospitais universitários em organizações sociais, que afetariam principalmente as instituições onde trabalham, parecem ser um assunto cuja discussão é remota, situada em torno de 1995. Como a proposta de autonomia universitária não se concretizou, houve um arrefecimento do tema.

"Ultimamente, não tenho ouvido falar muito na autonomia universitária. Há uns 4 anos atrás se falava mais sobre essa questão da autonomia universitária, onde vai ser discutida essa questão da transformação dos hospitais universitánios em organizações não govemamentais. Há uma inversão nessa relação dos hospitais universitários com o Estado, na questão de independência econômica, que ele teria que gerar, hospital teria que achar uma forma de se auto-sustentar."

As normas que mais tiveram impacto sobre os trabalhadores foram as que alteraram a previdência social. Há um misto de indignação, indiferença e conformismo com as mudanças das regras do jogo;

“(...) Eles começaram a cortar, cortaram tudo, a gente está pagando por coisas que aconteceram lá atrás. Quem não tinha culpa levou, e quando cortou, cortou tudo de uma vez. A gente está em um momento de transformação, não estou gostando, eu tenho as minhas perdas. Outro dia eu pedi para puxar o meu tempo de casa, estava nos meus planos me aposentar com 48 anos e, agora você tem o bendito do pedágio que vai ter que pagar (...)". 
"Claro, mas eu me sentiria envergonhado. Eu conheço pessoas que se aposentaram aos 50 anos, ainda que do lado da lei. Eu me sentiria assim, puxa vida, se eu estou aposentando com 50 anos de idade - o almoço não é de graça, se você está comendo alguém está pagando, se você não estiver pagando alguém está pagando para você. Não tem saida".

“(..) Os brasileiros estão todos acostumados a sempre mudar a regra do jogo, você vai ficando assim, mais uma que mudou. Nesse ponto não me incomoda muito ter que trabalhar, se vou aposentar agora, se não vou, porque eu acho que não adianta também, que vai ficar morrendo de raiva à toa. E uma coisa que eu não faço conta, para não me estressar, mas eu reconheço que quem tivesse contando com isso, na hora que tivesse no finalzinho e a porta fechou, e fez inclusive com que muitas pessoas se aposentassem um pouco antes (...)".

"Eu acho que para mim alterou demais. Porque eu ia trabalhar 25 anos, comecei a trabalhar muito novo. Eu tenho 42, ainda vou ter que trabalhar mais 11 anos, e sempre trabalhei com atividade insalubre, e comecei a trabalhar com 18 anos".

Outro ponto amplamente citado foi o achatamento salarial e a desmotivação

por que passa todo servidor público. A manutenção da estabilidade para o servidor público è controversa.

"Eu perdi em questão de aumento. Na época do Samey, eu comparei o meu salário com o salário que eu recebia no João XXIII. Eu ganhava 10 vezes o salário do João aqui, hoje um funcionário do João ganha o dobro do que eu ganho. É uma perda muito grande. Estamos há praticamente 7 anos sem aumento, continua tudo a mesma coisa, a demanda cada dia aumentando mais, isso é obvio, que a tendência é só aumentar e o salário continua o mesmo. A insatisfação é geral. Isso é verdade. Há muita cobrança e o salário mesmo continua o mesmo. (...)".

“(...) A reforma do Estado, eu acho que ela vê muito a questão dessa coisa, dessa perda de estabilidade. Eu nunca imaginei que eu fosse estável no HC, muito embora juridicamente e pelas normas da universidade, eu deveria ter esse privilégio. Eu nunca usei ele, mesmo porque eu vivo o dia de hoje, amanhã eu nem sei se vou estar viva, e vou ficar preocupando com estabilidade? Estabilidade eu acho que construo todos os dias. Então, eu tenho uma visão mais ou menos diferente da maioria das pessoas. Eu acho que o RJU só se toma necessário porque a gente vive num país de coronelismo. Se a gente não fosse, se a gente tivesse uma visão muito mais aberta do que seria o Estado, a gente não precisa de RJU. Eu não preciso de garantia nenhuma de estabilidade nenhuma, não. (...)". 
"Seria um passo de retrocesso, se for para nessa nova situação a gente ter que se submeter a esses feudos, porque há apadrinhamento sim. Com a falta de estabilidade, o que segura, o que motiva a pessoa a ir para frente é uma certa estabilidade. Eu discordo da colega por causa disso. Mas para muitos, ele saber que não é qualquer coisa que vai tirá-lo do sistema quando ele tiver na fase de dificuldades da saúde que ele vai ser descartado, como determinados hospitais fazem. Então isso dá na equipe como um todo um elo de união para se aperfeiçoar para buscar essa assistência melhor possivel (incompreensivel). É fator de motivação. (...)".

"Tem uma enfermeira que entrou na universidade há 3 anos atrás e ela nunca trabalhou. Então, a gente tem essas coisas que são o mal do regime jurídico, da estabilidade. As pessoas já entram mal intencionadas dentro da universidade. A estabilidade tem outras coisas que as pessoas usam (...)".

É interessante observar que a principal fonte de informação, além da grande midia (radio, televisão e jornal) é os boletins de sindicatos ou de representações de categorias profissionais;

"Já ouvi comentários jomalísticos, às vezes, quando a gente tem alguns encontros, escuta em assembléia".

"Sobre a previdência a gente acompanha no jomal. A gente sabe disso, é através do noticiário que eu fico mais enfronhada".

“(..) tudo que eu ouvi falar sobre a reforma do estado, no que tange à universidade, li muito em jomais internos da universidade, do sindicato e outras coisas similares e, de uma maneira geral, eu fiquei com muita dificuldade de avaliar isso, porque eu sinto essa leitura enviesada por uma oposição sistemática (...)".

$\dot{E}$ consenso que os anos 90 trouxeram mudanças, em especial para as organizações e os trabalhadores do setor público de saúde. Mudanças também vivenciadas pelo $\mathrm{HC}$ e seus trabalhadores. Três destas se destacam: as mudanças no financiamento; as das relações de trabalho e as da estrutura, organização e gestão do HC.

É unânime entre os trabalhadores que a procura de sobrevivência, devido ao desfinanciamento progressivo por parte do MEC, que paga somente parte da 
força de trabalho, teria induzido o $\mathrm{HC}$ à alternativa de auto-sustentação, como a de produção e venda de serviços ao setor público (SUS) e privado (planos e seguros de saúde);

"Mas, no entanto, o que acontece agora, é que esta responsabilidade foi transferida. Nós dependemos agora do municipio, antigamente o hospital era da universidade. Você falou: ah, não sei como fazia! Fazia o seguinte: tinha dinheiro para tudo porque eram verbas, vinham do governo federal, sei lá, do Ministério da Educação, da Saúde, vinha verba, porque havia essa ligação. Você não tinha que ganhar do SUS, não tinha isso não, isso ai foi uma coisa que foi mudando".

"Isso tudo que o pessoal tem falado, essas reformas, a lei da sobrevivência, porque se você tinha uma verba destinada, de repente agora você não tem. O MEC se limitou a pagar o que? Só os funcionários que estão aqui dentro. As outras coisas o $\mathrm{HC}$ tem que bancar, inclusive uma parte dos funcionánios contratados por fora. Os gastos nós temos que bancar (...)".

É consensual que o HC poderia até mesmo ser auto-suficiente com a venda de seus serviços. Isto, no entanto, não redimiria o Estado de financiá-lo, uma vez que, além da assistência, o HC é um hospital público de ensino e pesquisa;

“(..) hoje, em alguns seminários realizados no $H C$, inverteu-se a coisa - nós temos que ter uma assistência de boa qualidade para ter um ensino de boa qualidade e passamos a vender o serviço de assistência. E com isso, cobra-se mais do servidor a produção, para que possa entrar o recurso para pagar uma folha paralela, que deveria ser uma folha paga pelo MEC. Que na minha concepção, o HC para prestar assistência e ensino e pesquisa, tinha que ter pelo menos a sua folha bancada pelo MEC, porque o ensino está lá dentro do hospital. Então, o MEC vê o HC como uma fonte produtora de senviço, e portanto, ele tem que vender serviço para se manter e hoje, o HC sem ter realizado concurso há vánios anos, dos 2000 funcionários, $40 \%$ é paralelo e o hospital tem que bancar essa folha. (...)"

Entretanto, não há consenso entre os grupos sobre as conseqüências da abertura do $\mathrm{HC}$ ao mercado de venda de serviços ao SUS. Para os grupos dos médicos e pessoal de nivel superior, a maior inserção do HC no 
SUS/BH permitiu sua abertura para a sociedade, com a criação do pronto atendimento clínico e com a disponibilização de seus leitos para a central de leitos e suas consultas para a central de marcação de consultas da Secretaria Municipal de Saúde de Belo Horizonte - terminando com a usual clientela cativa. O HC tornara-se quase que um "plano de saúde" para esta clientela que conseguia romper as barreiras do acesso. No entanto, para os trabalhadores administrativos, técnicos e de serviços gerais esta abertura para o SUS restringiu o acesso da clientela que vinha do interior e até mesmo de outros estados;

“(..) Hoje, o compromisso que ele tem com a sociedade é muito mais ético do ponto de vista social. Eu acho que do ponto de vista social o hospital é muito mais ético. Isso eu acho que é reflexo da estrutura, do sistema de saúde que a gente vive. Enquanto o $\mathrm{HC}$ se preocupava só em ser um hospital universitário, que não tinha compromisso com a sociedade, e nós ouvimos isso em 97, quando o Guerra (secretário estadual de saúde) falou que se fechasse o HC não ina ter problema porque o papel social dele era muito pequeno para a comunidade de Belo Horizonte. Eu acho que desse ponto de vista nós somos muito mais éticos do que éramos em 97, sem dúvida que somos".

“(..) Eu acho que nós temos um movimento de doentes que eu não tive quando eu era estudante. Eu acho que nós temos condutas mais uniformes, nós temos uma vigilância, um controle muito maior uns em cima dos outros, essa coisa mais próxima você está mais em cima da minha conduta. Eu acho que tem uma amarração muito melhor, eu acho que tem um fluxo muito melhor. $E$ outra coisa, eu cá acho que nós formamos médicos muito melhores do que eu fui formada (...)"

"Ele não está voltado mais para o aluno, não está voltado mais para o ensino, está voltado para o lucro. O SUS paga, a prefeitura paga, todo mundo paga, então aceita todo mundo. $O$ aluno não está prejudicado? Ah, não, tem muita gente para você estudar, gente que veio pela UNIMED e outros convênios. Mas, a finalidade de ensino fica prejudicada. Atende todo mundo, ai você vai no ultra-som - são poucas as vagas - então vamos marcar a do convênio. O aluno como fica?".

"(..) tirando o SUS, porque o SUS que atrapalhou o hospital todinho. Quando não tinha o SUS, o pessoal ia, ficava na fila e 
conseguia ser atendido. Entrou o SUS, para você conseguir um oftalmologista e deixar o pedido, fica um ano para marcar, no posto de saúde. Quando não tinha SUS, toda segunda-feira tinha ficha na clínica médica, na oftalmologia, na dermatologia, não tem mais".

Para os funcionários administrativos, técnicos e de serviços gerais a "abertura para o SUS" trouxe outra conseqüência: dificultou o acesso dos servidores pelo tradicional "jeitinho" ao HC. As consultas são agendadas e referenciadas pelo posto de saúde municipal e as internações têm que passar, ou pelo Pronto Atendimento do $\mathrm{HC}$, ou serem encaminhadas pela Central de Internação o que diminui a possibilidade de se conseguir informalmente uma consulta ou internação;

"Eu vou descer o pau sim, com relação a nós funcionários. Eu falo para os outros que o hospital para nós, funcionários, não vale nada. O hospital gosta mais de atender um indigente do que atender um funcionário. Infelizmente, já tive experiência".

“(...) A gente não pagava INSS, passou a pagar, a maioria dos médicos, era de médicos mais antigos e a gente tinha um jogo de cintura com eles, uma prestação de favor mesmo, o que eu precisasse aqui a gente conseguia na base da amizade, você intemava, fazia qualquer tratamento. Hoje não tem mais isso. Eu acredito que é coisa do Femando Henrique, com a CPMF, abriu mão dos planos de saúde, que cada dia está aumentando mais e o salário nosso não acompanha e a pessoa não tem condições de pagar um plano (...)"

"Piorou. Tudo tem que ser autorizado ou marcado pelos postos de saúde. Nos postos a pessoa fica mais de ano tentando marcar consulta e não consegue. Eu trabalhava no ambulatório de oftalmologia e vem uma pessoa conhecida que pede uma consulta e eu falo que não tem condição, tem que ser agendado, tem que bater no final, senão como vai ser com o SUS?"

Entretanto, é unanimidade entre os participantes dos grupos que outra conseqüência do aprofundamento da inserção do HC no SUS foi, no ambiente interno, a intensificação dos controles de registro (fichas de admissão, prontuário médico, solicitação de exames, etc), e no externo o 
aprendizado de negociação e interlocução com os gestores do SUS municipal e estadual;

\begin{abstract}
"Eu que entrei aqui há seis anos e meio, quer dizer, seis anos e meio é pouco, mas trabalhava fazendo, você atendia o paciente não tinha uma ficha que você atendeu. Hoje você já fica o tempo inteiro - você tem ficha, tem isso, você atendeu, ele chega você pede a ficha, o que tem na $\mathrm{AlH}$, qual que paga, é tanto? Então vamos fazer essa AlH que o diagnóstico determinou. Mas você sabe que é muito da gente, essa questão do faturamento tem muita gente que não está nem ai para essa postura, não.(...)".
\end{abstract}

"Nós vamos continuar fazendo o que nós estamos fazendo, os casos complicados, mas nós temos que aumentar o que todo mundo tem, que é o filé, que ninguém manda para cá. A central de leito quando liga para gente ela quer mandar o osso. Agora a gente fala você quer mandar o osso? Então me manda três filés juntos. Ela fala que já mandou, e a gente diz que se ela mandar três filés, nós aceitamos o osso junto, senão não vamos aceitar. Porque senão não tem condição, fica aqui, o tempo inteiro gastando, gastando internação em CTI, 15 dias de CTI, e os outros fazendo, e o dinheiro do SUS vai para todos. Antes tinha as verbas do governo, hoje não tem".

"(...) Para bancar essa folha, de valor alto, tem que vender bastante serviço e ainda tem a deficiência de negociadores do HC com a administração pública municipal e estadual, que parte do serviço prestado é glosado, então o HC realiza o trabalho e não recebe nem da municipalidade nem do Estado. Isso vem deteriorando a qualidade dos serviços, vem causando estresse nos trabalhadores (...)"

Os convênios com planos e seguros privados de saúde somente foram considerados como boa alternativa pelos médicos (inclusive de aumento de sua renda). Para as outras categorias é visto com desconfiança e como forma de privatização do hospital;

“Já tem cartaz aqui no ambulatório falando: Quando você tiver que intemar o seu paciente, interne no HC".

"Tudo bem, mas eu acho que nós deveriamos continuar tendo espaço inclusive para os clientes que podem pagar e ter alguma coisa que seja diferenciada. Eu não entendo porque nós temos que ficar sofrendo, e trazer para cá só os abacaxis, que você não vai ganhar nada, que é só o ensino, nada disso. Eu acho que uma coisa não exclui a outra." 
"Mas está aumentando muito o número de atendimento de particular e de convênio no hospital e a tendência parece que é diminuir um pouco o atendimento ao SUS. Mas essa clientela, essa parcela de particulares vão aceitar acadêmicos aprendendo? E se aumentar essa clientela mais privilegiada?".

"E a gente sente também, sobre a questão da mudança, quase que privatizando, também no contexto funcional, de funcionários. Você já não vê mais o servidor público dentro da instituição como presença maior. Então, devagar, eu acho que está havendo uma mudança, tanto de atendimento quanto de pessoal administrativo, porque cada vez mais há uma terceirização através de até concursos mesmo, mas que não é mais um servidor público que está ali e está descaracterizando, na minha visão, a finalidade $(\ldots) "$

As mudanças no financiamento, na legislação trabalhista, previdenciária e as formas alternativas de contratação, utilizadas pelas organizações públicas de saúde para contornar a rigidez imposta pelo Regime Jurídico Único, vão ser apontadas como responsáveis pelo emaranhado e as dificuldades de relação entre trabalhadores e gerência e entre os próprios trabalhadores. Estas alterações levaram à convivência, num mesmo espaço de trabalho, de pessoas com vários vinculos e com diferentes graus de benefícios e de proteção ao trabalho. Desta forma, os médicos se queixam da precariedade do pagamento como autônomo, via cooperativa de trabalho, os celetistas (principalmente administrativos, técnicos e serviços gerais) dos conflitos e discriminação dos estatutários, que têm estabilidade. Os trabalhadores da UFMG reclamam da diferença de tratamento em relação aos outros servidores da Universidade;

"Mudou a relação do trabalho médico, dentro da própria instituição HC. Mudou a relação do trabalho médico fora do hospital, a organização dos médicos no serviço com a formação de uma cooperativa que não tem fim especifico para nós, médicos do hospital. Na verdade, ela seria um órgão que, especificamente, por uma norma do governo, da questão do repasse financeiro dos pagamentos dos honorários médicos, por não poder ser feito mais 
diretamente pela instituição, alegando que era por mecanismos trabalhistas, por indenizações indevidas - que o governo achava indevidas, que a gente deveria ser pago, então, através de uma cooperativa, para a gente não ter vínculo direto com as instituições. Mudou essa relação do médico com a instituição. Ele é do hospital, mas na hora do reconhecimento do trabalho, do pagamento do trabalho, mecanismo de força, de luta dele, ele não é do hospital, ele pertence a uma cooperativa. Isso eu acho que desorganizou um pouco a mobilização de dentro do hospital, apesar de que a classe médica permanece, como um todo, mobilizada."

“(..) Então, hoje ainda abusa muito, porque lá é FUNDEP e UFMG, UFMG deita e rola e FUNDEP tem que trabalhar, (...) que quase tudo é FUNDEP, então fica mais nas nossas costas. Às vezes o próprio funcionário te ameaça. Ele te pergunta se você pode trocar a folga com ele, você diz que não, ele fala que então você se prepare para ser mandado embora. Então, tem esses tabus muito grandes.(...)"

"Nós temos dois órgãos - FUNDEP e UFMG. Quem manda mais no HC, é a FUNDEP ou a UFMG? Lógico, quem tem que mandar é a UFMG, o chefe é da UFMG, mas não, quem manda é a FUNDEP. O chefe da FUNDEP pega um cara da UFMG e fala "se eu pudesse eu mandava todos os funcionários da UFMG embora. Mandava agora."

"Então, o pessoal da UFMG que trabalha no HC é tratado de forma diferente do restante do pessoal. (...). Então, o tratamento salarial da FUNDEP é diferente do tratamento da UFMG, que recebe menos. Então, quando vem o tratamento para folgas, para direitos, de ponto facultativo, disso ou daquilo, é igual para todo mundo, seja da FUNDEP, porque trabalha no hospital. Mas, nos olhando como funcionários da UFMG trabalhando no hospital, nós somos olhados diferentes do restante."

Todos são unânimes em afirmar que estas alterações trouxeram aumento da carga de trabalho, seja pela queda no número de funcionários (aposentadoria e demissões que não são repostas, nem pelo MEC ou pelo Hospital), pelo aumento da produção (venda de serviços), seja pelo maior controle exercido pela gerência;

"No meu setor aposentou e não pôs ninguém no lugar. No meu setor, éramos 22, hoje somos 9, mas tem três com problema. Um não pode ir no hospital, tem que ficar na oficina, o outro não pode pegar peso, então diminui e está havendo cobrança. O governo 
não põe ninguém e não abre um concurso, ou a própria diretoria do HC pela FUNDEP."

"Igual o meu setor, que é um setor que precisa de muito trabalho. Aposentaram 5 pessoas, sairam 2 pessoas por doença e até hoje não colocou ninguém lá. Então, aqueles que estão lá estão trabalhando desdobrando, para soltar o senviço. E a chefia fala que está esperando ordem, que não pode pedir ninguém que é ordem que eles tem de não aceitar ninguém para trabalhar. Tem que fazer com aquelas pessoas que estão lá. Então, está desse jeito".

"O que aumentou muito, em contraste com os outros setores, ou as outras unidades funcionais, como são agora classificados, se para vocês diminuiu o número de atestados, para nós aumentou $50 \%$, porque o pessoal não está agüentando o fluxo de paciente, o fluxo de serviço que está sendo dado para nós, em relação ao que deveria ser. Então, está ficando muito pesado. Há dias que em uma escala de 12 pessoas, tinham 7 trabalhando, onde a maioria estava de licença médica, até de 15 dias, alguma coisa mais séria como edema, LER, cirurgia. Eram coisas que não poderiam evitar mesmo".

É unânime a percepção do sucateamento, atraso tecnológico e perda de recursos humanos pelo $\mathrm{HC}$ frente ao setor privado, nestes tempos de reforma;

“(..) Eu fico vendo que hoje, no HC talvez por ser vinculado a órgão federal, acho que mais ainda do que setores municipais, estaduais, porque eu vejo que outros hospitais públicos começaram a fazer mudança bem antes, talvez no início de 90. Eu entrei para cá em 95, mas acho que foi a partir de 98, 99 que a coisa começou: nós temos que mudar. A crise de 94, acho que deu uma mexida, não vivi outras crises aqui, só essa, mas acho que deu uma sacudida. (...). Acho que a diretoria mesmo, a partir de 98 começou a fazer essas mudanças e a diretoria atual está dando continuidade, e eu tenho sentido que as pessoas estão envolvidas. (...)".

"Nos últimos anos, os hospitais púbicos foram ficando cada vez mais obsoletos, em matéria de equipamento, de recursos humanos também, porque não pode mais investir em recursos humanos, repor a aposentadoria dessas pessoas, repor a mão de obra e, não sei se a própria política universitánia - aí eu não seide re-direcionamento do hospital, readaptação do empregado, do funcionário, dentro da própria instituição. Ela favorece não só a gente ficar sucateado do ponto de vista material como do ponto de vista também dos recursos humanos. (...)". 
Relataram que houve resistências às mudanças implementadas no $\mathrm{HC}$, através de mecanismos que vão desde 0 aumento da burocracia, emperrando fluxos, até o aumento do absenteísmo por atestado médico. Para todos os grupos, ponto relevante foi a questão do absenteísmo (folgas e atestados médicos), visto como falta de comprometimento e de cooperação no trabalho, pois tem sobrecarregado os trabalhadores assíduos;

"Demais. O que há é resistência. O que houve e o que há é o tempo todo resistência. Eu estou aqui o tempo todo pensando numa coisa que eu nunca não tinha pensado. A ficha caiu agora reforma do estado - essa ficha está me caindo aqui, agora. A coisa que mais há é resistência. Eu acho que há resistência de todo tipo, em todos os lugares. Resistências justificadas, resistências que justificam fluxos que deveriam ter melhorado, resistências que emperram, emperram às vezes até o que poderia estar bom. Muito por uma - não sei - por desinformação, ou por inércia, ou por dificuldade de mudar. Eu acho que o que mais há é resistência à mudança, em todos os setores, genericamente, eu não sei falar como é isso (...)".

"Aumentou o número de atestados. Depois que o Femandinho teve a brilhante idéia de descontar o vale e o tíquete no dia da falta, deu uma melhorada boa. (...).Depois dessa brilhante idéia de cortar vale alimentação, diminuiu bastante, mas mesmo, assim, ainda tem, mais UFMG, porque os da FUNDEP trabalham. Eu tenho uma colega da UFMG que tem 13 anos de serviço, ela não tem falta, eu sou FUNDEP, tenho 7 anos, e não tenho falta, nem atestado. A gente trabalha de qualquer maneira, doente ou não."

"Meu setor não tem falta não, mas eles arrumam umas folga. Trabalha uma hora a mais, fica uma semana folgada. Nunca vi uma coisa dessas. A chefia trabalha duas horas a mais, fica três dias de folga. Só as folgas que eles amumam, trabalham dez minutos a mais, tem um dia de folga".

“(..) até que falta, não tem. Tem uns que encostam. Ele vem, chega no serviço, toma um café, senta, ai chega a hora dele ir ao médico, ele vai, não pega nem atestado, volta de novo. Tem uns que fazem isso e os outros ficam trabalhando para ele, ai nós vamos desdobrando".

"Ai é que eu falo que a lógica é perversa, porque as pessoas que estão faltando são sempre as mesmas, pelo menos no meu setor. Você, por exemplo, que está lá dedicando para fazer os fatos 
acontecerem, você que vai ficar estressada por falta de um que não tem postura profissional, que falta, por vezes, não por doença, que sabe que é capaz de chegar no SAST e conseguir uma licença de cinco dias, porque está com gripe, enquanto a outra que está com gripe continua trabalhando. Eu acho que é esse comprometimento com a instituição, pelo pouco tempo que eu vivi antes da mudança de 95, tinha mais nas pessoas, as pessoas vestiam mais a camisa".

Os trabalhadores de nivel técnico e de serviços gerais criticam o excesso de cargos de chefias e a pouca comunicação e participação nas decisões nos setores;

"Diminuiu um pouco a chefia - porque aqui tem muita chefia e pouco funcionário. O que fizeram no Rio Grande do Sul? Diminuíram um pouco de enfermeira, de chefia. Aqui nós temos setor que tem, não vamos falar o nome, vamos falar quantas pessoas tem. São quatro enfermeiras-chefe e quatro secretánias, acho que deve ser uma para cada enfermeira, e setor precisando de gente. A gente deveria pegar essa reportagem sobre Porto Alegre e trazer para o hospital e implantar. Dá para fazer com o próprio funcionário público. Vai gerar lucro e o funcionário vai ganhar. O funcionário do Rio Grande do Sul ganha, tem participação. Se fizer isso aqui vai diminuir o desperdicio dos funcionários que têm. Porque tem uns espinitos de porco que falam - ah, estão pagando mesmo."

"Sobre o problema da chefia, ela procura resolver o caso com aquela burocracia, lenta. E a gente como funcionário quer resolver a coisa mais rápida, que o caso sendo resolvido você vai superar os problemas de atraso. Muitas vezes, fim de semana, a chefia não vai, acontece um problema e a gente está lá, nós mesmos comunicamos um com o outro e resolvemos. E fica aquela coisa pendente para segunda-feira, a chefia está ai, ela vai resolver. Passa aquela semana inteirinha sem resolver com a chefia ali, $e$ no final de semana a gente toma a entrar com o mesmo caso que a gente resolveu com os colegas, para fazer de novo, que passou uma semana e a chefia não resolveu. Exige mais da gente. Se a chefia tivesse um pouco mais de diálogo, de compreensão, mais debate com os funcionários, a gente se expunha mais, mas acho que a gente chegaria num ponto certo."

Relatam, ainda um refluxo do movimento sindical, que precisaria se adequar aos novos tempos, e um maior temor de perderem o emprego (principalmente os celetistas) e conseqüentemente uma redução das greves; 


\begin{abstract}
"O sindicato hoje não está capacitado para negociar. Aquela concepção de sindicato combativo ou sindicato de negociação, sindicato de resultado, hoje ele não existe mais. Hoje, alguns dirigentes do sindicato tinham que estar qualificados para sentar na mesa e negociar. Até àquela época a gente vê que tinha muito mais articulação do ponto de vista de sindicalização, em relação a isso. Isso não é realidade só dentro do HC muito menos só na Universidade, mas é um reflexo mundial, a gente vê que o boom do sindicato foi até 95 ."

"A mudança que está tendo, é uma mudança geral, no mundo inteiro, no Brasil inteiro. Esse medo... porque o sindicato está fraco? $E$ porque a turma antiga era um grupo que tinha mais união. (...) Então, o funcionário público hoje, ele é considerado um emprego, que você pode contar com ele. Lá fora é um emprego que cada dia você está em um. O funcionário público não, é um trabalho garantido e você não quer perder ele, porque é garantido. O sindicato está perdendo a força, nós, da UFMG, estamos perdendo a força. (...)"
\end{abstract}

$\mathrm{Na}$ Tabela 28 podemos ver os valores mais relacionados ao conceito de eficiência, pelos trabalhadores do HC.

TABELA 28 - Valores correlacionados ao conceito de eficiência pelos trabalhadores do Hospital das Clínicas/UFMG

\begin{tabular}{|l|l|}
\hline \multicolumn{2}{|c|}{ Eficiência } \\
\hline Bem feito, na hora exata & Presteza, no menor tempo possível \\
Competitividade & Agilidade e fazer perfeito \\
Responder prontamente aquilo que é & Competente \\
solicitado & O custo e o benefício \\
Uma boa assistência & Excelente \\
Ética & Resultado com os meios disponiveis \\
Otimização & Fazer o melhor que pode \\
Produtividade; & Menor número de ações possível \\
Produzir o trabalho em tempo hábil & Objetividade \\
Profissional & Ter resolução. \\
Qualidade & Melhor distância entre dois pontos \\
Reduzir custo & Resolutividade \\
Satisfação do paciente & Coletividade \\
\hline
\end{tabular}

Fonte: Dados de pesquisa primária: grupos focais 
Para a maioria dos trabalhadores, sem distinção de categoria profissional o conceito de eficiência está relacionado com o conceito de qualidade, a fazer bem feito (assistência), o melhor possivel, ter resolução;

"Eficiência para mim é você produzir, exercer seu trabalho em tempo hábil e com qualidade. Desde que ele saia e tenha um atendimento da melhor forma possivel, acho que isso é eficiência".

"Produtividade com qualidade, um trabalho com qualidade".

"Eficiência é ser competente nos seus afazeres e atender com qualidade, no tempo minimo também".

"Quando eu penso em eficiência eu penso em uma coisa bem superior, o melhor que existe e às vezes nem sempre é assim. Na minha cabeça, é uma coisa excelente, o melhor possivel".

"Eu acho que eficiência é um funcionánio que o chefe mandou ele fazer aquele serviço, sabe que aquele serviço vai ser bem feito, na hora exata, e não vai prejudicar setor nenhum".

"No mecanismo de trabalho, eu acho que eficiência é atingir o melhor objetivo esperado, com a melhor qualidade, envolvendo o menor número de ações necessárias para aquilo".

Por outro lado, a concepção econômica também está presente na percepção

dos trabalhadores, como otimização, redução de custos, custo/benefício;

"Eu fico pensando o que é eficiência na saúde. Bom, eu acho que é uma boa assistência. Agora, o conceito de assistência, eu acho que está atrelado à questão de resultados e à questão de recursos e você tem que buscar o melhor recurso que dê uma assistência".

"O hospital não tem condições de estar disponibilizando os melhores medicamentos para todo mundo, por aí não vai conseguir fazer a cobertura necessánia. Então você tem que estar sempre buscando isso, otimizando o recurso, mas assegurando assistência de qualidade. $E$ ai a gente tem que considerar $o$ contexto que a gente vive, de escassez de recurso".

"(...) que ela tenha de fato uma condição de assistência boa, livre de risco, quantidade com qualidade de baixo custo, que é o que a gente quer e prega isso constantemente". 
"É o resultado, o mais rápido possivel, com menos custo possivel, menos despesa possivel, para ter o melhor resultado possivel, é eficiência. A resolução correta."

Valores bastante ligados ao da eficiência foram o tempo, capacidade técnica

e satisfação do paciente, fatores primordiais em um hospital;

"Fazer bem, no menor espaço de tempo. Atender quem nos procura com presteza, no menor tempo possivel, gastando recursos materiais o mínimo necessário para realizar o processo de atendimento com qualidade".

“O paciente já havia passado por vários hospitais e eles não deram conta. Segundo informações, aquele paciente morreria com aquelas lesões e aqui no hospital, não. O paciente foi até o setor administrativo, agradeceu, foi até os médicos, agradeceu. Eu vi uma eficiência nesse ponto de vista, uma satisfação do paciente e nós ficamos satisfeitos em saber que podemos atender bem."

"Eficiência é ser competente nos seus afazeres e atender com qualidade, no tempo minimo também (...)".

Podemos dizer que os trabalhadores do $\mathrm{HC}$ ao reintroduzirem no conceito de eficiência as condições necessárias, ou pressupostas, para que o melhor desempenho ocorra, estabelecem uma relativização e subjetivação do conceito de eficiência, a eficiência possivel, circunstanciada;

"A questão de eficiência hoje, eu fico analisando, é atingir um determinado resultado. Meu objetivo é manter o atendimento. $100 \%$ seria eu atender da forma como o usuário espera, mas como eu não tenho condição, no presente momento, dado (risos) ao meu meio de trabalho, às deficiências que eu tenho, eu ainda acho que estou sendo eficiente. Agora, se você fizer uma pesquisa de cima para baixo e perguntar se eu estou sendo eficiente, eu acho que isso vai ser relativo, na visão deles vai ser que eu estou sendo ineficiente. Depende da visão. Dadas as circunstâncias, os resultados que eu estou alcançando com os meios que eu disponho, eu estou sendo eficiente, o meu setor está sendo eficiente. Em termos do meu trabalho, da minha forma, eu acho que estou sendo eficiente. Mas quando você começa a analisar de fora para dentro, o nivel de expectativa da pessoa com relação ao trabalho, ao resultado alcançado, eu acho que não. Por isso eu estou falando que a questão da eficiência é relativa, depende da perspectiva". 
"Hoje eu acho que o meu setor está na faixa de $70 \%$, precisa melhorar muito. Mas quando eu coloco a questão de eficiência, tem que ter os meios para você ser. Então, dentro das condições que hoje a gente tem, acho o meu setor eficiente; ele pode não atender $100 \%$ as expectativas, mas em termos dos meios que eu tenho para ser, ele é eficiente."

"Eu acho que se eu fizer o melhor que eu posso dentro do meu limite, dentro das condições que eu tenho, eu vou ser eficiente $e$ ser um hospital público".

Não há consenso sobre se o hospital das Clínicas é eficiente, entre e dentro dos grupos. No entanto, é unânime a opinião de que o $\mathrm{HC}$ é hoje mais eficiente do que no passado recente. O conceito de eficiência, dentro de condições reais, é novamente colocado;

"Sobre o hospital, eu acho que ele está caminhando para isso, é um processo longo e doloroso, é a questão da dor mesmo. Eu digo, por exemplo, em termos de planejamento. Você monta uma idéia, coloca no papel, divulga. Você tem que sair corrigindo, tem que identificar e sair corrigindo. Não tem como você falar que o hospital é $100 \%$ eficiente que ele não é, eu diria que ele está em $60 \%$, ele está caminhando".

"Eu acredito que o hospital agora está começando a trabalhar nesse sentido de eficiência, antes eu diria que não, mas agora eles estão crescendo. Há uns altos e baixos, como se fosse um elevador da vida, mas entre os altos e baixos a gente tem um crescimento agora maior. Novas aparelhagens têm melhorado o nivel de vida do paciente e o melhor atendimento, mais rápido com mais qualidade para o paciente. Acho que nesse sentido, sim."

"Eu acho que a gente está numa cultura de tentar ser eficiente, era uma preocupação que não tinha e que hoje o hospital tem. (...)".

Foi consensual em todos os grupos que um hospital público pode ser eficiente e ter qualidade, entretanto, como isto poderia se dar é controverso;

"O hospital público pode ser eficiente e para ser eficiente ele tem que ter um planejamento, ele tem que ter uma gestão eficiente e que envolva o coletivo. Acho que a participação é muito importante, a descentralização.(...)". 
"Eu acho que o hospital público pode ser eficiente e continuar público a partir do momento em que os dirigentes municipais, estaduais e federais se comprometam com a instituição pública, como retorno dos impostos pagos pela população e o usuário do senviço público use com racionalidade e seja conscientizado para isso e os trabalhadores daquela unidade de prestação de serviço ao público também sejam estimulados e conscientizados para usar o recurso público a bem da população e com racionalidade".

"Você aqui passa por muitos entraves, mas é o lugar de minha escolha, de minha confiança, que eu recomendo, porque o produto final, para mim, a meu ver, é o que tem maior qualidade e é o que interessa no que diz respeito à saúde, você se interessa pelo produto final. Às vezes gasta mais tempo para fazer? Gasta. Perambula mais? Perambula, mas realmente o produto final, que é a saúde, o resultado final que interessa, aqui eu acho que você tem um produto excelente. Poderia ser melhor? Às vezes poderia, mas dentro das condições que existem agora no sistema de saúde, não só nas instituições públicas como privadas, aqui oferece um senviço excelente. Não é o ideal, porque ideal também é difícil, não existe, a gente trabalha para o ideal, mas oferece um senviço excelente".

Entre as dificuldades para que o HC seja um hospital eficiente se destacam a necessidade de recursos financeiros e os aspectos gerenciais. Dentro da gerência são apontados como fundamentais a participação, a melhor comunicação entre diretoria/chefias/funcionários. Os mesmos itens são apontados como solução por todos os grupos;

"Nossa, é difícil! Tem que mexer em diversos setores. Tem que ter comunicação, depende também de verbas do governo e tem que saber administrar, distribuir, repassar para cada setor, para cada coordenação ser eficiente".

"(...) Acho que a questão seria uma boa administração, com verba. Porque acho que tem as duas coisas. Não adianta quem está lá em cima querer mudar o hospital, sem ele ter condições para isso. O HC sendo um hospital escola, de incentivo à pesquisa, teria que ter o incentivo público, para ele dar continuidade ao que ele é, não deixar cair".

"Eu fico pensando se o gerenciamento não vem primeiro do que o recurso, porque para você conseguir captar um recurso, o gerenciamento tem que ser muito bom. Porque o recurso está ali, ele está rodando, tem uns que conseguem captar e ver aquilo ali. Então, eu acho que o gerenciamento é o principal, é o que mais 
emperra. A maior dificuldade - o gerenciamento bom de todos os serviços".

"A meu ver, tem uma distancia muito grande entre os funcionários e a administração. Acho que há necessidade de chegar mais junto, de maior diálogo, que a gente não tem. A gente conhece, pelo menos. Se chegar uma pessoa lá e perguntar quem é o diretor eu sei falar o nome, mas quem é? A maioria dos funcionánios não conhece. Eu acho que falta esse entrosamento entre a administração e o funcionalismo, para gente chegar e expor os problemas para ele. Às vezes a gente até acha, mas há tanto protocolo, tanta barreira, que às vezes a gente está aqui malhando e eles nem sabem o que está acontecendo, porque tem muitas barreiras, que impedem da gente chegar junto da administração para ver os problemas que estão acontecendo."

\subsubsection{Percepção, incorporação, resistência e redefinição do conceito de eficiência pela gerência intermediária}

Os gerentes de unidades administrativas e assistenciais mostraram pouco conhecimento e interesse pelos temas da reforma do Estado, exceto o da previdência. Todos são unânimes em afirmar que a aposentadoria precoce dos servidores, devido às novas regras impostas pela Emenda Constitucional $n^{\circ} 20$, levou à perda de pessoas chave dentro da instituição, à desorganização de alguns serviços e ao aumento dos gastos do HC com mão-de-obra, pois as aposentadorias não são repostas pelo MEC. A queda de estabilidade, também é lembrada;

"(...) A gente percebe, essas repercussões não são diretas no nosso cotidiano, no nosso dia a dia, mas elas são bastante evidentes no contexto social. Não só de geração de sensação de instabilidade, como na prática, com vánias modificações. Por exemplo, na universidade, o número de professores que se aposentou com medo das alterações é enorme. Há uma perda irreparável disso, nós tivemos essa experiência. E esses professores, em grande número, estão indo para outras universidades. Tem um lado bom, sob certos aspectos, mas isso é uma repercussão muito evidente disso." 
"(...) Aqui no hospital, especificamente, o que nós sentimos foi uma quantidade muito grande de aposentadorias, de perdas de funcionários que o hospital teve. Pessoas inclusive experientes que acabaram buscando a aposentadoria, até pelo medo das modificações que isso teria, então isso é um problema. Você retinha as pessoas dentro do serviço público pela estabilidade, quando você teve essa perda do fantasma da estabilidade, as pessoas deixaram de ter esse encanto, talvez, pelo serviço público. (...)"

progressivo descompromisso do MEC com a folha de pagamento do $\mathrm{HC}$ que passou a contratar funcionários com recursos próprios através de contratos regidos pela CLT foi apontado como um dos principais problemas nas relações de trabalho dentro do Hospital;

Existe, até porque tem setores no hospital que o tratamento até de plantão é diferenciado. Tem setores do HC na área de assistência, que quem é FUNDEP, trabalha noite sim, noite não no plantão de 12 por 60, que eles chamam e o pessoal UFMG trabalha um dia sim e dois não. Até essas condições são diferenciadas. Outros setores não. Então, no HC há muitas situações e a gente está fazendo um esforço e tem começado a estabelecer diretrizes para que as coisas sejam mais igualitárias, mas há tratamentos, hoje, diferenciados, até nessas questões. Então, há muito conflito, não é pouco não.

Além das alterações nas relações de trabalho e previdenciária a forma de financiamento, ou de não financiamento, foi a principal mudança trazida pela reforma do Estado no setor saúde. As alterações na forma de financiamento, que já vinham desde o governo Collor, se consolidam no processo de reforma do Estado do governo Fernando Henrique e do setor da saúde. O desfinaciamento, pelo governo federal (MEC), das atividades do HC empurram-no para a venda de serviços ao SUS e para convênios e planos privados de saúde.

"(..) Na minha época, inicio da década de 80, o hospital era totalmente dependente do Ministério da Educação, do govemo. Toda verba vinha pelo govemo, por isso que nós, no hospital, nunca nos preocupamos, desde essa época que o hospital 
vivesse de recursos próprios: fazer convenio, etc, porque todo recurso vinha do MEC e quando havia necessidade de suplementação, a gente solicitava. Às vezes que eu solicitei, eu tive só dois anos, a gente conseguiu verba suplementar. De modo que não tinha preocupação em gerar recursos próprios.(...)"

“(..) A politica do governo faz com que nos obrigue a ir contra, inclusive nossos principios de pensamento. Hoje nós estamos preocupados em manter o hospital aberto, porque a gente sabe que fechar um hospital desse significa estar fechando mais um atendimento à população de Belo Horizonte, do estado e inclusive de muitas regiões do Brasil. Então hoje a gente já começa a discutir o que a gente não deveria atender, porque o prejuizo é muito grande para a instituição. A gente começa a discutir aumentar leitos privados para aumentar a arrecadação com leitos privados para poder custear a manutenção dos leitos públicos (...). Isso significa que o hospital que antes não pensava em nenhum momento na possibilidade de estar disponibilizando um número maior de leitos privados dentro do hospital, se vê obrigado a fazer isso para sobrevivência na manutenção da instituição e do ensino universitánio."

As mudanças no financiamento e as alternativas encontradas pelo $\mathrm{HC}$ para contornar as dificuldades decorrentes são vistas até mesmo como positivas, pois impulsionaram um processo de reestruturação e reorganização gerencial do $\mathrm{HC}$, mudança da imagem do hospital na sociedade e no ensino de graduação e pós-graduação;

"Na população atendida, hoje o hospital, efetivamente, é um hospital inserido na rede. (...). Outra grande coisa que aconteceu é que essa dificuldade, essa penúria financeira, e as próprias observações de deficits crônicos, levaram à proposição de um sistema gerencial novo, mais eficiente, que está sendo implantado no momento, que é o sistema das unidades funcionais. Não sabemos ainda qual vai ser o desdobramento, na prática disso, mas ele pretende ser uma coisa mais ágil."

"O HC vem adotando uma nova filosofia de descentralização que eu acho oportuna, que certamente vai frutificar, que é o conceito de unidades funcionais, onde estão descentralizando, muito, 0 processo de gerenciamento, delegando aos chefes, aos responsáveis - eliminando essa figura de chefe, e sim procurando instituir a figura de uma administração mais compartilhada, mais em conjunto com os grupos. (...). Acho que isso poderá advir em aspectos altamente positivos para a melhoria da instituição. Então, algo novo e vamos esperar que realmente surta os efeitos que espera" 
“(..) Hoje o aluno está vendo aqui o que ele vai ver lá fora, então ele tem o poder, um conhecimento maior ele não vai se assustar quando ele chegar e sair para o mercado de trabalho. Pô, lá no HC é uma maravilha, eu faço medicina de ponta e aqui. Não, as dificuldades que ele vai trabalhar lá fora ele vai trabalhar aqui dentro. O problema é esse, você supentotou o hospital, hoje a gente trabalha com uma superlotação."

Por outro lado, também são consideradas como negativas, sendo que o principal receio é de que as alternativas de financiamento utilizadas possam levar à privatização do Hospital.

"Inclusive eu acho que o sistema público de saúde ele tem que ser público, porque senão não dá não. Quem trabalha com saúde, nós trabalhamos com a preocupação estritamente saúde, sem o lado econômico. E o médico, o servidor de saúde, ele é muito pressionado pelo lado econômico. Quando eu defendo, por exemplo, um investimento maior do ponto de vista privado do HC é uma finalidade única: financiar o SUS. É a única forma que eu imagino, de ter, por exemplo, o convenio particular no $H C$, desde que ele tenha o objetivo estritamente preciso de financiar o setor público de saúde."

É interessante notar que todos os entrevistados relatam que existiu e existe resistência às mudanças ocorridas nesta última década, mas geralmente elas não são explícitas e nem organizadas. Aparecem mais como pequenos boicotes, desinteresse, medo do "novo". Mas para a maioria dos chefes de setor elas não são intransponiveis;

"Em meados do ano passado aconteceu uma greve, a categoria lutando por uma melhoria das condições de trabalho, da questão salarial, das questões de condições de trabalho, mesmo. Não acredito que tenha sido pelos processos intemos de mudança que estão sendo propostos no hospital. Agora, boicotes, há, "mils". A gente sente que até a própria coordenação dos serviços, coordenação médica, está muito resistente ao processo intemo de mudança, porque eles vão ter que se envolver, se comprometer de uma forma diferente a que eles até então vêm se comprometendo no exercicio profissional deles. Eles vão ter que conversar mais com as pessoas, eles vão ter que trocar mais idéias com as pessoas, eles vão ter que compartilhar mais as decisões e isso, eles estão resistindo demais. Mas não é só a coordenação médica, não. A gente sente boicote até de 
funcionários administrativos, talvez de funções mais de inicio de carreira, também, pela própria resistência à mudança."

"(...) É um ambiente com sérios problemas, mas o que acontece nessa questão, ele não tem o conhecimento do seu papel naquele processo de trabalho, ele não tem essa visão, ele acha que ele não precisa vir, ele pode faltar, que ele pode boicotar, que ele não é importante. Ele não se sente parte do processo, ele não se sente inserido. A mesma coisa é o funcionário da limpeza terceirizado. Alguns funcionánios eles não se sentem parte. É uma minoria que participa, que busca, que reivindica, que tem consciência. Eu acho que ainda tem uma acomodação muito grande ou não acreditar na mudança. Alguns que falam: eu não acredito na unidade funcional, mas no entanto não participam, não chegam perto."

"Agora eu percebo que é interessante, o estudante e o residente resistem em ir à área de convênio não SUS. Porque ele acha que ele está trabalhando para o colega de graça. Eu não vejo nenhuma diferença da presença dos estudantes na área de convenio SUS e na área não SUS. (...) Por exemplo, hospital SOCOR - eu fui acadêmica do SOCOR anos - é todo convenio não SUS, e lá tem acadêmico, estudante, residente em todo lugar. Agora, aqui, quem quer fazer essa limitação não são os clientes não, são os próprios estudantes."

Para a gerência intermediária não há dúvida que o HC é hoje uma organização mais voltada ao ambiente externo, aberta ao dialogo com os diversos niveis de governo e com as diferentes instâncias da sociedade e até mesmo com o setor privado;

“(...)Também houve uma melhora significativa na medida que o hospital se inseriu na rede pública. Ele deixou de ser a mansão do cachorro bravo. Hoje, por exemplo, o hospital utiliza serviços da rede privada, paga por esses serviços, de uma forma mais fluida. Serviços que não são feitos no hospital, exames de laboratórios, exames de imagem, paga por isso, de uma forma mais tranqüila. A transferência de pacientes em situações em que isso é possivel, por exemplo, através de convênios, de planos de saúde, que a maior parte da rede privada não trabalha com o SUS, ou trabalha minimamente com o SUS. É possivel, por exemplo, hoje, através da Central de Leitos da Central de Marcação de Consultas, a gente transferir um paciente para um CTI de outro hospital, ou transferir de outro hospital para a enfermaria do HC, para um tratamento (...)."

"Com o setor privado, o hospital está engatinhando na sua relação, particularmente com os planos de saúde. Agora que o 
hospital está iniciando, há coisa de dois anos, a parte de convenio com os planos de saúde e a comunidade de um modo geral e tem que se preparar para que ele possa pelo menos $30 \%$ - parece que a legislação determina isso, que $70 \%$ tem que ser dedicado ao atendimento ao SUS"

Também reconhecem que houve estreitamento das relações dentro da própria comunidade universitária, especialmente com a Reitoria. A inclusão do HC no Conselho Universitário é visto como ponto de aproximação com a Reitoria. Por outro lado, é questionado porque as contas de manutenção do HC (água, luz e telefone) não são pagas pela reitoria como acontece com as demais unidades. É interessante observar que as chefias administrativas, assim como os funcionários nos grupos focais, expressam um "inconformismo" pela utilização do HC pelas Unidades Acadêmicas da UFMG, sem nenhum ressarcimento financeiro para o Hospital. A relação com os sindicatos parece ser pouco conflituosa, talvez pelo arrefecimento do movimento sindical na década dos 90 ;

"A princípio, os reitores, hoje eles sabem que eles podem ter uma boa gestão ou uma péssima gestão, de acordo com o que o HC diz. E com isso eles estão se dedicando um pouco mais ao hospital, eles estão enxergando o hospital como uma unidade da própria universidade. Antes eles achavam que era a escola de medicina a responsável e deixavam o hospital de lado. A escola de Medicina não tem como bancar o hospital, embora antes eles possam estar ligados. Hoje tem uma ligação direta com a reitoria e está tendo um tratamento diferenciado."

"Eu olhando isso pelo lado financeiro, que é a parte que eu conheço mais, eu me sinto incomodada um pouco com a relação dessas unidades com o hospital. Eu enxergo muito mais uma questão de que essas unidades usam o hospital como campo de trabalho, como campo de aprendizagem e tudo mais, e não dão nenhum retorno para o hospital, não dão nenhuma ajuda para o hospital no desenvolvimento dele. Eu não vejo isso. Eu acho que elas exploram muito mais o hospital no que elas precisam ser dar nenhum retomo."

"O HC tem dois sindicatos. Na verdade, nós temos sindicatos dos docentes e sindicato dos funcionánios técnico-administrativos. $O$ 
que eu posso dizer é o seguinte, que do ponto de vista geral, nós tivemos uma queda muito grande na organização não só dos sindicatos, do movimento social dos sindicatos, mas também das associações em geral. Nós estamos tendo uma desarticulação enorme dos sindicatos e das associações como um todo"

$\mathrm{Na}$ Tabela 29 podemos ver os valores mais relacionados ao conceito de eficiência, pela gerência intermediária do $\mathrm{HC}$.

TABELA 29 - Valores correlacionados ao conceito de eficiência pela gerência intermediária do Hospital das Clínicas/UFMG

\begin{tabular}{|l|l|}
\hline \multicolumn{2}{|c|}{ Eficiência } \\
\hline Desempenho & Agilidade na prestação de serviço \\
Grau de satisfação do usuário & Qualidade do serviço prestado \\
Equilibrio entre quantidade e qualidade & Redução de custo \\
Funcionar adequadamente & A dimensão da qualidade (relação \\
Excelência & Cumprir sua função adequadamente \\
Satisfatório & sem ter reclamação \\
Prestar um bom serviço & Conscientização \\
Exercício de uma atividade da melhor & Comprometimento \\
forma possivel & Formação e capacitação \\
Menor custo; & Fazer cada vez mais e melhor e com \\
Melhor resultado & qualidade \\
Otimização & Dar conta do recado \\
Descentralização & Satisfação do usuário \\
\hline
\end{tabular}

Fonte: Dados de pesquisa primária: entrevistas

A maioria dos gerentes (chefes setores administrativos e assistencial) do HC apesar de relacionarem conceito de eficiência com qualidade não esquece sua dimensão econômica.

"Ela tem sido vista nos últimos tempos na sua dimensão econômica: melhor resultado, menor custo. Acho que é bastante recente a introdução de um outro elemento, que eu considero fundamental, tão fundamental quanto o custo e os resultados, que é o lado qualitativo das coisas. Na área de saúde, a questão do que a gente chamaria de ética institucional, da relação ética entre 
o profissional e o usuário, eu considero hoje - não só eu, isso é uma coisa mais ou menos já aceita de uma forma mais extensa a dimensão da qualidade, da relação humana entre profissionais e usuários, ela passa a ser um determinante fundamental da eficiência."

"Hoje é qualidade. Acho que é um equilibrio entre quantidade e qualidade. Acho que o ponto chave da eficiência é o paciente lá no final ficar satisfeito, tanto o funcionário quanto os professores, e a gente como médico ficar satisfeito com o trabalho desenvolvido."

"Eficiência é o exercício de uma atividade da melhor forma possivel com o menor custo. Eficiência para mim é você ser capaz de fazer cada vez mais e melhor e com qualidade."

Outro valor correlacionado é o tempo, agilidade no fazer bem feito e o trabalho coletivo.

"Eficiência eu relaciono muito ao sentido de desempenho. Agilidade, na qualidade do serviço prestado."

"Enquanto for uma comunidade trabalhando estanque é muito dificil você ser eficiente. Você ser eficiente isoladamente, não considero nem mérito pessoal, diria que é uma coisa mais acidental."

"Por exemplo, um porteiro eficiente é aquele que cumpre sua função adequadamente sem ter reclamação, a secretária a mesma coisa. Então, você pode ter eficiência no seu trabalho. Então, se você for eficiente na proposta de trabalho que você tem e no que a comunidade espera de você, então você cumpriu a sua função."

É importante ressaltar que, novamente, as condições necessárias para que a eficiência ocorra, foram relacionadas. Esta subjetivação é questionada por um chefe de setor "o problema é que estamos achando que somos eficientes com pouca realização".

"Tem pontos de estrangulamento que se não forem resgatados com o tempo, dificilmente poderemos ser eficientes não dispondo dos meios próprios para alcançá-los. E isso exige autonomia, isso exige meios, recursos financeiros, recursos humanos qualificados, uma estrutura ágil e que se ajuste a um perfil da realidade que vivemos e não de uma estrutura que vai sendo degradada, 
degradada com o tempo, deformando, inclusive, o conceito de eficiência."

"Dentro da estrutura que existe hoje, ele é muito pouco eficiente. Acho que a eficiência do hospital hoje teria que medir, seria um hospital que está sobrevivendo a tantas crises e com tão parcos recursos! Eu acho que ele é eficiente no sentido de sobreviver com tão poucos recursos que são oferecidos a eles. Como ele faz isso é uma outra questão. Ao mesmo tempo a gente tem um termo de comparação que é o Hospital de Clínicas de Porto Alegre. É considerado uma fundação que tem uma verba anual de 160 milhões de reais, nós temos 25 milhões de reais. Eles são eficientes? Eu acho que se você for verificar o número de pacientes que eles atendem e o número que nós atendemos, nós somos muito mais eficientes do que eles. Agora como isso é feito e o grau de frustração das pessoas que atendem lá e aqui e o grau de satisfação do paciente, isso eu não sei se seria a mesma."

No entanto, quando confrontado com o conceito de eficiência propugnado pelo MARE, a maioria assume os valores básicos da proposta: custos, resultados, qualidade para o cidadão. Outros afirmam que a preocupação central da proposta do MARE seria a redução dos gastos/custos, e que a utilização de valores como qualidade e cidadania seria somente uma forma de tornar a idéia mais palatável, seria uma simples frase de efeito;

"Tenho grande vontade que isso saia do discurso. É um pouco vago isso, naturalmente como convém a essas definições gerais. Eu não sei, nesse atual govemo, qual pode ser a esperança nossa em que isso seja real, não seja apenas um discurso, e que não haja apenas a redução de custos como uma questão importante, o resto é para enfeitar a frase. O objetivo é redução de custos, ai põe uma porção de outras coisas para ficar mais simpático, politicamente simpático."

"Esse conceito está ótimo. Agora tem uma coisa que afeta muito a gente, a gente não tem dinheiro para ser eficiente. Agora, o governo tem que preocupar com isso. Isso é o correto, essa definição de eficiência, mas a gente também tem que ter dinheiro para ser melhor."

"A gente tem que ver quais são esses custos que vão ser reduzidos. Às vezes você tem que elevar alguma coisa para poder ter o restante: a qualidade do serviço e melhorar o atendimento para o cidadão. Se você cortar custo e isso levar a um corte de algum serviço, não compensou." 
Apesar de reconhecerem que o $\mathrm{HC}$ aumentou sua eficiência nos últimos anos, os chefes de divisões/setores assistenciais e administrativas são unânimes em não considerá-lo eficiente;

"Não acho que o HC mereça essa designação de eficiência, como a gente pensa esse termo hoje. Ele é muito lento, ele tem uma burocracia excessivamente pesada e há uma questão muito séria, que agora está sendo trabalhada, pela primeira vez de uma maneira ostensiva, clara - sempre foi trabalhada, mas de uma forma muito obscura - que é o compromisso com a produção do hospital."

"Eu acho que ele busca a eficiência, tem um trabalho, tem uma semente que está sendo plantada para isso. Acho, isso prova até na nossa produção, a nossa produção diz isso, as estatísticas mostram. O hospital hoje ai melhora a taxa de ocupação, aumenta transplante, aumenta número de cirurgia - mais ou menos, cirurgia não aumenta muito, não, mas aumentou um pouquinho, de cinco anos para cá aumentou. Acho que tem que aumentar mais? Tem. Ai vem projetos, como a unidade funcional, que vem dar uma sacudida na gente. Vem o PLIDERH. A receita do hospital de 5 anos atrás e agora fica claro o tanto que a gente melhorou. Convenio particular aumentou nosso faturamento. Por que tem isso também, a gente faturava, mas não arrecadava. Então, isso provou: ah, você tem que anotar aquilo que você faz, o procedimento que você faz tem que estar anotado, aquilo que você gastou. E isso foi aos poucos, então a gente, com certeza o hospital melhorou. Isso sem dúvida e tem que melhorar mais."

“(...) Apesar da gente ter a sensação: nossa, esse HC não dá, ele sempre está devendo que coisa horrorosa. Quando você vai fazer um estudo retrospectivo você identifica que nós não estamos deixando perder tanto, quer dizer, nós melhoramos o gerenciamento financeiro do ponto de vista dos últimos dez anos. Temos devido sim de um ano para o outro, mas menos do que nos anos anteriores. Isso é um sinal de que apesar da política do govemo ser perversa, ser contránia, estar querendo destruir a instituição, a instituição tem encontrado mecanismos, que podem não ser até os politicamente corretos, mas ela tem encontrado mecanismos para sobreviver e ela tem conseguido ser eficiente nisso."

Os entraves para a melhoria da eficiência do $\mathrm{HC}$, apontados pela maioria da gerência intermediária, foram de cultura original vista como autoritária, hierárquica e sem consciência dos valores de eficiência e, o pouco 
comprometimento de seus trabalhadores, em especial os dos professores e

médicos, com o dia a dia do $\mathrm{HC}$;

"(...) Outro entrave que eu acho que é um entrave muito concreto ainda, é o entrave cultural. Esse é um entrave sério no hospital. $O$ HC ainda tem uma hierarquia muito grande sob o ponto de vista das competências. Aqui ainda tem a cultura de que o docente é melhor do que o técnico-administrativo. Entre os docentes, tem a cultura de que os médicos são melhores do que os outros. Entre os técnico-administrativos tem a cultura de que o chefe sabe mais do que os outros. Isso é entrave. Eu acho que a gente já melhorou muito. Nós já avançamos. (..) A nossa cultura ainda é uma cultura autoritária. Apesar de sermos uma universidade democrática, nós temos uma cultura autoritária e hierárquica. Nós temos uma cultura muito autoritária na formação de profissionais de saúde."

"O maior de todos, no meu ponto de vista, é a cultura do hospital, é a inércia inerente da forma de trabalhar desse hospital durante tantos anos. As pessoas acreditam que seja natural ele ser lento. Esse é um aspecto, um outro aspecto é que não existia até muito recentemente - acho que não existe ainda na quantidade suficiente - consciência da necessidade de eficiência: consciência de custo, consciência de racionalização de ações. (...) É um achado extremamente recente. (...) O bloco cirúrgico tem um tempo de preparo da sala, entre uma cirurgia e outra, da ordem de seis vezes mais longo do que num hospital privado, e não é melhor. Não é seis vezes melhor em termos de esterilização, limpeza da sala, ele é igual, mas ele chega em alguns momentos, em alguns dias, a ser seis vezes mais longo. Isso obviamente reduz muito o número de cirurgias. Esse tipo de situação é uma situação curiosa, porque essas pessoas são terceirizadas, inclusive. É uma empresa terceinzada que faz essa limpeza. $\dot{E}^{\prime \prime}$. muito curioso isso, é uma coisa cultural."

"Primeiro recurso orçamentánio e financeiro. Segundo acho isso tão difícil. Porque o hospital precisa até internamente, por exemplo, isso que eu estava falando, o médico precisa querer trazer o paciente dele para cá. Isso é muito importante, lógico que a diretoria tem essas dificuldades para convencê-lo a fazer isso. Ele quer levar para o BIOCOR, para o SOCOR, ele não traz para cá, isso, lógico, está afetando o nosso resultado.."

Outro entrave relevante foi a necessidade de uma gerência profissionalizada, com autonomia, flexibilidade e agilidade na tomada de decisão. É interessante observar que apesar de ser considerada por alguns, 
como o mais importante, a falta de recursos financeiros não seria, para a

maioria o entrave fundamental para que o $\mathrm{HC}$ alcance maior eficiência;

"Começa primeiro por uma boa administração. As pessoas que administram o $\mathrm{HC}$ e que administraram são muito bem intencionadas, mas na hora que elas aprendem já está na hora de sair, e já está desgastado. Então, isso é fundamental. Agora, para ter uma boa administração eu concordo que tem que ter recursos. Agora, a maneira de captar recursos fora, no mercado, é muito lenta, o desenvolvimento é muito lento. Se nós tivermos recursos e profissionais da área administrativa, acho que ele se tomará bastante eficiente, mesmo na estrutura que nós estamos inseridos no momento. Lógico que você tem que ter uma força política para brigar com o grande comprador de serviço do hospital é o SUS, via prefeitura. Então, acho que essa estrutura tem que ser um pouco modificada também."

"Primeiro a administração. Acho que tem que ter uma administração profissionalizada. Como já disse para você, deve ser gerido por um economista, empresários, etc. Todos os setores do hospital, setores de contabilidade, por exemplo, deveria ser genido por um indivíduo profissional, em dedicação exclusiva. A gerencia do hospital, então, acho que é um fator importantíssimo. Em segundo lugar, o professor de medicina tem muitos setores no hospital que ele dá suas aulas e não faz mais nada. (...) Poucos se dedicam ao hospital e trabalham no hospital pelo que ele ganha na faculdade, sem ter nenhum outro recurso extra, no hospital. E o médico faz isso, talvez porque muitos não tenham aqui o atendimento e as condições de trabalho que ele tem, por exemplo, em outros hospitais. Principalmente, eu acho que se melhorar as condições do hospital, tanto fisicas como técnicas, se melhorar a gerência do hospital isso vai melhorar."

"É muito difícil uma instituição pública, devido às dificuldades que eu mencionei, de reposição de pessoal, de natureza financeira e sem nenhuma autonomia financeira e de gerenciamento, ela é muito subordinada às normas do govemo que hoje restringem ao máximo a ação de qualquer instituição pública, ela ser eficiente (...). E o dirigente está subordinado a isso, então ele não tem flexibilidade, ele não tem meios para tomar a instituição com a eficiência desejável para competir no mercado, que a iniciativa privada não dispõe desses entraves."

As soluções para a mudança cultural contemplam o pagamento de produtividade como motivador maior de participação dos servidores e profissionalização gerencial, ambas propostas estão contidas no projeto de Unidades Funcionais. As soluções financeiras viriam de uma maior 
interlocução do HC com os gestores, municipal e estadual, e com o MEC assumindo a folha de pagamento dos celetistas e autônomos;

"A solução mais rápida, mais fácil, inatingivel eu acho, seria isso dar dinheiro. As pessoas receberem pela sua eficiência, ficariam eficientes semanas. Essa solução não é possivel. Então, o tempo, essas incursões que estão sendo feitas mesmo. Eu acho que a atual linha de ação das duas últimas diretorias - essa e a anterior - que têm implantado no hospital, têm sido bastante eficiente para se conseguir mais eficiência na cultura devagar, quase parando do hospital."

"A profissionalização da direção do hospital, em todos os seus niveis. Desde o diretor, superintendente, até chefes de setores especializados, devia ser ocupado por pessoal especializado. $O$ médico, eu sempre digo, o maior cargo que ele deve ter no hospital é diretor clínico; diretor clínico, chefe de senviço, chefe de serviço especializado."

"Se o MEC assumisse a folha FUNDEP, que é um valor muito alto, ajudaria o hospital que ele poderia investir mais."

Todos concordam que um hospital público pode ser eficiente e continuar público. Não haveria contradição nesta relação. Ressaltam, porém, que para isso acontecer seria imprescindivel a valorização dos servidores e o estabelecimento de uma cultura gerencial;

“Não é fácil porque o govemo - engraçado, ele está querendo primar pela eficiência, pela transparência, mas em nenhum momento ele preocupa com a gente, com o servidor público. Em nenhum momento ele está preocupado com o senvidor público. Então, ser eficiente e ser instituição pública é uma arte. É uma arte. Você tem que gostar do que você está fazendo, para você acreditar que um dia você vai dar certo, que aquilo que você faz é importante para alguém. Às vezes o servidor público ele fica tão descrente com o que o governo está fazendo com ele, que às vezes ele pode até pecar nesse sentido. Quer dizer, você ser instituição pública e ser eficiente, você tem que estar gostando muito do que está fazendo e acreditar em alguma coisa, que alguma coisa vai ser diferente."

"O que depende para um hospital público ser eficiente depende de você saber aplicar uma política adequada e para mim a política adequada é a política da valorização do trabalhador. Não é salário que significa valorização do trabalho; salário é importante, é, mas não é o mais importante. A valorização se dá no reconhecimento 
do resultado de seu trabalho gerencial, pela capacitação. Existem várias outras formas de você valorizar o trabalhador. Pelo programa de incentivo ao desempenho, onde você vai tratar de forma diferente os diferentes; eu não posso considerar da mesma forma aquele cara que nunca faltou, que trabalha todo dia, que vem até doente trabalhar, que produz, da mesma forma que um outro que não vem, que falta, que não dá nem resultado. Então, nós temos que aprender a valorizar as pessoas conforme os resultados que elas apresentam no trabalho, mas não só do ponto de vista individual, principalmente do ponto de vista coletivo. Essa é a forma. E é a forma que o hospital está construindo e tem melhorado a sua eficiência em cima disso."

"Então, uma instituição pública pode ser muito eficiente, desde que ela tenha uma cultura de gerenciamento e que as pessoas concordem com isso, trabalhem com isso, vistam a camisa, o que é muito dificil, e não é apenas dinheiro".

É interessante ressaltar que apesar de não colocarem a cidadania e a responsabilização (comprometimento) como valores definidores em seus conceitos de eficiência, quando solicitados a fazerem uma correlação entre eles, todos os entrevistados os colocam, juntamente com a qualidade, como inseparavelmente contidos no conceito de eficiência;

"O hospital público só vai ter qualidade se ele for eficiente, no meu ponto de vista. Eu não acredito em qualidade sem eficiência. A qualidade para mim está dentro do processo de eficiência, porque como eu vou ter qualidade sendo ineficiente? O ineficiente não tem qualidade."

" $\dot{A}$ medida que somos eficientes, tomamos mais acessivel a assistência à população. À medida que essa assistência é mais ampla, o conceito de cidadania é mais resgatado pela população, no seu direito de ter isso não como uma benesse, uma concessão e sim como uma obrigação do Estado. Então nós temos, nesse sentido, sendo como somos, servidores, funcionários do governo, de procurar resgatar essa cidadania do cidadão, assegurando a ele uma assistência à saúde com dignidade, com respeito, com menos fila. Com mais respeito, sobretudo."

"Também, é uma coisa da definição. Não tinha pensado exatamente nisso antes, eu incluiria na cidadania, o direito da pessoa de ter acesso, de ter oportunidades iguais, ter serviços oferecidos iguais. Eu acho que o que se pretende de uma instituição pública cuja vocação é exatamente a grande massa populacional, eu acho que o conceito de cidadania deve fazer parte do conceito de eficiência, de qualidade." 
"É fundamental, as coisas são interigadas. Não tem jeito de eu ter um serviço eficiente se eu não tiver responsabilidade, porque eu tenho que ter um compromisso, um compromisso com que? Com essa instituição que eu trabalho, com as pessoas que eu atendo; eu tenho que ter compromisso com aquilo que é programado para poder chegar e fazer, então se eu não tiver compromisso e responsabilidade, não tem com eu ser eficiente. Não existe como."

\subsubsection{Percepção, incorporação, resistência e redefinição do conceito de eficiência pelos diretores e ex-diretores}

Os diretores e ex-diretores do $\mathrm{HC}$ se mostram mais bem informados sobre a proposta de reforma do Estado, principalmente as referentes à previdenciária (fim da aposentadoria especial, aposentadoria por idade), a administrativa (mudanças no RJU, da estabilidade, as organizações sociais) e as privatizações. Conhecem, mais profundamente, algumas de suas conseqüências: o achatamento salarial, a redução do número de servidores, a instituição de pagamento de incentivo para os professores das universidades federais. $O$ objetivo da reforma seria a modernização, a racionalização dos custos, tornar a gestão pública mais flexível, eficiente. A crítica mais freqüente se refere à perspectiva de tornar o Estado cada vez menor (Estado mínimo) fugindo de suas obrigações sociais, com objetivo único de racionalização econômica.

"Eu acho que tem problemas de eficiência, mas não podemos dizer do serviço público como um todo que ele é ineficiente. Acho que tem alguma coisa ideológica nisso aí. Agora, de outro lado tem também alguma coisa de racionalização financeira, de custos, alguma tentativa de melhorar os custos, tomar mais flexivel a gestão. Penso que tem uma coisa que é uma idéia de melhoria de funcionamento, de eficiência e junto alguma idéias relativas a ter mais flexibilidade sobre a gestão, a gestão de pessoal, diminuir custos, esse tipo de coisa." 
"(..) no sentido de fazer com que o Estado cada vez se tome menor. Menor com a idéia de que esse Estado é pouco eficiente, ele deveria ser mais eficiente, ele deveria diminuir o tamanho do Estado, significando obviamente um menor número de pessoas diretamente vinculadas e algumas das funções que seriam exercidas, por exemplo, no hospital, na universidade, na faculdade, etc. e tal seriam exercidas por empresas terceirizadas. Isso é o que está por trás. E essa idéia do chamado Estado mínimo é a idéia de que o Estado anteriormente vigente seria um Estado uma máquina enorme, ineficiente e que seria apenas um ônus para a população, uma vez que essas pessoas têm que ser pagas e essas pessoas, então, estaniam na verdade, usufruindo dos impostos e gastando imposto que deveria ir para outra coisa. Essa que é a idéia básica da reforma do Estado, do Estado minimo, na minha concepção."

As alterações mais importantes na vida pessoal e profissional foram as mudanças na previdência, o achatamento salarial, a criação de um ambiente de incerteza e insegurança e uma maior cobrança de desempenho;

"(...) eu poderia ter me aposentado a partir desse ano, eu tive que aumentar o prazo para dezembro de 2003. Obviamente, que isso incomoda. Não sei nem se eu teria aposentado agora, mas é uma repercussão na minha vida pessoal. A questão, também, do salário, a gente tinha um direito a $20 \%$ a mais quando se aposentasse, agora deixou de ter, então, perda salarial mesmo. Pessoalmente, me incomodam muito essas coisas que a gente se sente lesada, prejudicada. Isso me incomoda."

"(...) o que eu tenho sentido é uma menor certeza de como que as coisas vão caminhar do ponto de vista de futuro, principalmente no sentido público, como é que a coisa vai caminhar. Como cidadão, um sentimento de insegurança de que o tapete nosso está sendo puxado, que tem gerado uma insegurança de futuro da gente, como cidadão, muito grande."

A municipalização e a mudança na forma de financiamento dos hospitais universitários federais são lembrados como os fatores mais importantes a influir na vida do $\mathrm{HC}$, nestes tempos de reforma. A passagem de um financiamento através de orçamento global para o baseado na própria capacidade de produção e venda de serviços, com a introdução de novos atores financiadores/compradores, vai acarretar mudanças na organização 
gerencial, nas relações de trabalho, e até mesmo na cultura deste hospital público de ensino;

"Nós hoje somos obrigados a ter uma gestão que tem que ser muito mais transparente, num certo sentido. Aquele conceito de gastar o dinheiro a fundo perdido acabou e acho que não sem razão. Uma certa transparência e o empenho no bom gasto do recurso público são coisas que estão em todos os setores, mas estão muito na saúde. Posso falar mais de perto do exemplo dos hospitais universitários, que antes recebiam recursos definidos a fundo perdido e hoje recebem seus recursos por produção. Isso foi uma mudança substancial. Esse aspecto e o aspecto do acesso, que tem a ver com eficiência e eficácia também, colocou o setor saúde num patamar de ter que responder, quer dizer, nós não podemos ser mais uma instituição fechada, burocratizada. Nós somos uma instituição que está dentro de um sistema que tem que responder às demandas da população. Dessa forma, eu acho que isso afetou de forma significativa o hospital."

As mudanças gerenciais são voltadas para a busca da responsabilização, da descentralização, da eficiência, da flexibilização, da agilidade na tomada e na implantação de uma decisão;

"Nós somos obrigados a mudar um pouco o paradigma da gestão, buscar uma gestão que seja mais rasa, com a questão da responsabilização, da descentralização, reconhecendo o hospital como muito lento nos seus processos, muito pouco eficiente entre uma definição estratégica qualquer e a consecução dessa definição. Então, nós fomos obrigados a mudar do ponto de vista da gestão. Essa gestão não só da questão da organização, dos organogramas, mas até também dessa questão da remuneração gerencial."

"Mas nós fomos obrigados a nos inserir. De lá para cá já houve uma mudança substancial na nossa inserção, tanto através de centrais de regulação, centrais de marcação, centrais de leitos, a oferta de cirurgias para o sistema, oferta de atendimentos especializados dos mais diversos tipos, a negociação com o gestor, à medida que se tomou gestão plena, nós temos tido as negociações com relação a metas e tetos feitas com o gestor e ele sempre tem em vista sua necessidade. Essas são coisas que mudaram substancialmente aqui na administração do hospital. Eu penso que a mudança da gestão ela também serve para fazer face, eu falo a mudança da gestão interna, a essas mudanças extemas, para que a gente possa ficar mais eficaz, mais ágil, poder responder melhor, para que a gente possa, inclusive, até produzir mais. Eu penso que há um paralelismo entre as 
modificações da gestão interna do hospital com as questões extemas que são colocadas para nós."

A flexibilização das formas institucionais de contratação para além do RJU, ou seja, pelo regime de trabalho celetista ou autônomo através da cooperativa de médicos do $\mathrm{HC}$, são apontadas como saídas para a não reposição de servidores estatutários pelo governo federal. Estas contratações são vistas como conflituosas e dispendiosas pelos entrevistados;

"Em relação à questão da relação de trabalho tem havido alterações. Por exemplo, a gente tem um número substancial de funcionários pagos pela Fundação, em virtude da não reposição. Eu acho que isso tem relação direta com a reforma do Estado. O funcionário CLT pago pela fundação da universidade vem aumentando. A gente tem um número grande de médicos que são pagos através de cooperativa. Isso também é outra mudança que houve em virtude da não contratação pelo govemo. Não só da não contratação, como também pelo próprio crescimento e aumento de complexidade do hospital. O quadro que a gente tinha de pessoal não fazia face a isso. O que a gente observa é que tem diversas formas altemativas de contratação que estão fora do RJU aqui no hospital."

A crise financeira pela redução de recursos a "fundo perdido" proveniente do MEC força o HC a buscar parceria com um novo ator: o gestor local do SUS. O avanço do processo de municipalização, com a transferência para o municipio de Belo Horizonte da gestão dos recursos do SUS em seu âmbito de atuação, distinguiu o gestor local como o grande financiador/comprador de serviços de saúde. Esta parceria vai levar a maior inserção do $\mathrm{HC}$ no sistema municipal de saúde de Belo Horizonte, abrindo suas portas para toda a clientela do SUS.

"Então tem o lado bom que pela própria constituição deveria estar inserido no Sistema Único de Saúde; por outro lado tem a questão de não ter opção, por que nós fomos abandonados pelo nosso 
pai. Acho que nós tivemos um bom padrasto no sistema de saúde. Então, aí eu acho que nós temos uma relação meio de padrasto até, mas para a população melhorou muito, hoje o hospital e assim imagino que os outros hospitais universitários, que não se responsabilizavam pela questão da saúde da comunidade que ele vivia; que tinha sua clientela cativa - nós tínhamos os nossos clientes, um cartão do hospital, os nossos clientes tinham um cartão, paciente vinha ao hospital, ele tinha direito, só ter o cartão. A grande desculpa era conseguir o cartão do HC, podia fazer exame, podia intemar, podia consultar e quem não tinha o cartão não podia fazer nada. Tinha inclusive tráfico de cartão. O pessoal pedia um agente para agendar uma consulta para ele poder ter direito ao cartão. E ai, hoje, o hospital certamente, é um hospital do SUS, com todas as mazelas de ser um hospital do SUS, e com todas as vantagens."

Além do SUS, o grande comprador de serviços, o HC também se abre para o mercado privado de saúde ao celebrar parcerias com o setor de convênios e planos privados de saúde, disputando num competitivo mercado.

"Houve um ligeiro aumento desse número, mas nunca atingindo aquilo que foi definido pelo Conselho Administrativo há mais tempo, muito tempo atrás, que é de 30\% . 30\% é o limite, $70 \%$ tem que ser SUS e no máximo 30\%, para não SUS, entrando ai particulares e convênios. Eu tenho impressão que eles devem ter esses dados, também, mas a minha impressão é de que não atinge $11,12 \%$ do total de leitos"

“(...) E muito dificil competir com outros hospitais da rede aqui de Belo Horizonte, por exemplo, por esses convênios. Esses convênios são limitados. 30\%, mais ou menos, da população brasileira tem convenio, alguns melhores outros péssimos que nem convenio na verdade é, igual esse da Santa Casa, que é uma porcaria. Então, o número de pessoas conveniadas é muito pequeno e o mercado que está querendo exatamente essas pessoas, é muito grande"

É interessante observar que a maioria dos diretores considera que a crise financeira levou à maior conscientização, por parte de seus diretores, trabalhadores e alunos do $\mathrm{HC}$, com a "responsabilidade pública" do hospital.

"Então, o que aconteceu? Com essa diminuição do financiamento do hospital, o hospital foi obrigado, já que havia uma limitação de orçamento e uma dependência cada vez maior dos próprios recursos para poder manter o hospital, houve uma implementação de determinadas medidas que agora culminam nesse processo de 
unidades funcionais, um processo de melhoria da gerência. (...) Claro que o único fator não foi a reforma do estado, houve também a consciência que não era correto manter um paciente no hospital por um tempo maior que o necessário para fazer as intervenções que eram necessárias. A gente nota, ao longo do tempo, principalmente agora mais recente, um aumento da taxa de ocupação e a diminuição do tempo de permanência. Isso é uma mudança muito grande no processo de trabalho lá dentro. Eu acho que isso fundamentalmente foi motivado, não por achar que isso era o mais correto, mas porque foi forçado devido à situação de penúria financeira. Foi obrigado a tomar medidas. $O$ desperdício diminuiu brutalmente, as compras melhoraram sensivelmente, comprar melhor, saber comparar melhor. Então, a crise de financiamento trouxe como conseqüência uma melhoria da gerência."

A resistência dos trabalhadores às mudanças gerenciais, assistenciais - no

atendimento a pacientes de convênios e planos de saúde - e nas relações

de trabalho dentro do $\mathrm{HC}$, são pouco explícitas.

"Não houve greve. Boicotes eu acho que também não poderia dizer, pelo menos coisas maiores, não. O que há é a discussão, é reclamação, às vezes o embate em cima da questão de cálculo de pessoal, por exemplo, e houve uma greve o ano passado. A greve foi uma greve salarial, mas houve uma preocupação na greve até, de que não houvesse um grande atingimento do atendimento à demanda. Mas, num certo sentido, eu percebia que se houvesse um comprometimento do atendimento, isso não era tão importante para eles, eles não se sentiam tão preocupados com isso como a gente, enquanto diretoria, se sentia."

"Não, boicote declarado nós não sentimos. Ele pode existir de forma velada, mas pelo menos na diretoria não tem chegado essas informações. Agora, o que a gente tem sentido do funcionalismo, dos sindicatos, (...) é que essa relação com o setor privado no hospital tem sido necessária. Até para conseguir bancar a assistência que a gente dá para o SUS. Eu vejo que hoje já não tem uma resistência tão grande quanto a que me contam que existia no hospital quanto a convenio e particular. É dificil para eu falar isso sobre o dia a dia, por exemplo, da enfermagem no oitavo ou décimo andar, mas chegar para a gente de forma declarada não. Tem tido algumas insatisfações, mais pela situação conjuntural do hospital, pela questão financeira a gente tem dito muito não para os funcionánios."

Chama atenção que a resistência à abertura do HC para o SUS é tanto por parte dos trabalhadores técnicos e administrativos e seu sindicato, devido ao 
aumento da carga de trabalho, como por parte dos professores que se

amparam no discurso da integralidade do atendimento;

"Greve, não, mas certamente, o que a gente pode observar a partir da discussão com o sindicato, principalmente, é que há uma resistência, sim. A percepção do sindicato, embora muitas vezes ele se manifeste favoravelmente ao que a gente chama de abertura para o SUS, abertura para o sistema de saúde, é que há uma certa sensação que a gente está fazendo um trabalho que não é nosso, ou de que não devia ser nosso, ou que de alguma maneira nós estamos sendo obrigados, de uma forma impositiva a atender esse número de pessoas, essa complexidade, sem nenhum retomo para o trabalhador, especificamente. (...) Mas o trabalhador não tem uma visão ideológica em relação ao SUS, por exemplo. Isso é uma coisa que está ficando clara para mim. Ele não defende o SUS; ele tem uma visão de qualidade, sim, mas é uma visão de qualidade que ele possa dominar, que ele domine os processos de trabalho, ele determine os processos de trabalho. Quando existe alguma coisa que parece vir de fora ele resiste. Então, ele fala que aquilo diminui a qualidade do trabalho, que aumenta o estresse, aumenta a quantidade do trabalho. Ele não consegue ter uma visão mais ampla no sentido de pensar que nós estamos fazendo parte de um sistema, esse sistema tem que atender uma determinada demanda. Não é uma discussão simples para dentro do hospital, eu acho que tem havido dificuldades."

"Na clínica médica os professores são mais resistentes. Isso eu sei por causa de conversas com a diretoria. Eles ainda têm aquela idéia que um hospital universitário tem que investigar tudo, tudo, tudo antes de dar alta. Então, se vocês olharem a taxa de ocupação da pediatria, é diferente da taxa de ocupação da clínica médica. A taxa de ocupação da clínica médica decaiu com muito menor intensidade do que a taxa de ocupação da pediatria. Então isso é uma resistência a que realmente a permanência hospitalar seja a minima necessánia para o paciente e não para a instituição como tal, quer dizer, isso não pode ser o critério principal. Agora também não se pode, $e$ aí há resistências muito sérias, por exemplo, no Conselho Administrativo. O Conselho Administrativo não admite, por exemplo, qualquer tentativa de melhorar, vamos dizer assim, a situação gerencial a custa de fazer com que o ensino seja prejudicado, há uma resistência enorme. (...)"

Além disto, com a maior inserção no SUS, o HC passa a se submeter à lógica e regras que norteiam o sistema municipal de saúde. Isto gerou perda de poder e resistências. 
"E também outras questões, o próprio SUS também com suas regras, quer dizer, marcação de consulta tem que ser lá, fazer cirurgia eletiva tem que ter autorização da junta e são coisas externas à universidade. E a universidade, muito ciosa do seu saber, essa coisa toda, as pessoas como da área da cirurgia, reclamavam imensamente de interferências indevidas da prefeitura, como a prefeitura vai estabelecer qual o limite que nós podemos operar? Até tipo assim: olha, nós não podemos mais intemar o doente que nós queremos. Até porque antigamente você era dono do seu espaço, então você me ligava lá em casa falando que queria intemar um menino e eu falava pode mandar para a pediatria e internar lá. Quer dizer, hoje não. Você tem que ir à prefeitura e tentar arrumar uma $\mathrm{AlH}$. Então, houve muita resistência porque as pessoas perderam essa coisa."

"Entre os funcionánios também teve muito menos que os professores porque para os funcionánios não mudou tanto. Eles já não detinham esse poder, você pode perceber no pessoal de marcação de consulta, ai sim, mais resistentes, porque na verdade era função dos funcionánios que detinham e muito bem exercido até, para quem marcar consulta, um certo trato entre aspas de prestígio, nessa questão: ah, eu posso marcar, eu consigo consulta para os meus amigos, conseguia consulta para os meus parentes e vizinhos para ser atendido e conseguia-se o cartão do hospital. Então, muito desse tipo de funcionário também reagiu. Agora, a grande resistência foi na área dos professores, principalmente esses que foram congelados, descongelaram, mas continuam respirando. Esses realmente..."

Os diretores afirmam que o Hospital vive uma interessante e, muitas vezes dificil relação com as três esferas de governo. Com MEC, órgão ao qual é hierarquicamente vinculado, ocorre um progressivo afastamento deixando de ser o financiador mais importante das atividades do HC. Por sua vez, a venda de serviço para o SUS levou à maior aproximação do Hospital com o MS e principalmente com os gestores municipal e estadual. Houve uma complexificação e maior escopo das relações do HC: hoje ele é um hospital federal universitário do SUS. Como disseram alguns entrevistados:

"Então toda nossa relação é com o municipio, alguma coisa ainda vem em nivel federal, alguma coisa estadual. Mas a grande parte do faturamento do hospital é todo negociado no nivel municipal. Mas, eu diria que seria assim, uma senhora com vários maridos. Porque ele tem uma parte no nivel municipal, por exemplo, SUS; 
ele tem que obedecer a uma legislação para contratos, para obtenção de novos recursos; ele tem que atender ao mesmo tempo o estado, porque ele tem uma abrangência a nivel estadual e na verdade, mesmo no SUS, ele trabalha com situações que são locais, que são estaduais e federais. Houve toda uma diferenciação, por exemplo, sua rede de recursos humanos é liberada a nivel federal; ele é regulamentado e auditado em nivel estadual por normas técnicas, construção, tudo mais e na parte contratual, auditoria, fiscalização, é feita ao nivel municipal. Então, na verdade, ele trabalha com os três niveis, mas houve uma inversão. Antes era prioritariamente ao nivel federal, hoje é ao nivel municipal, na parte de obtenção de recursos. Na parte de normas, é a nivel federal. Ele tem que jogar. Antes ele era muito ligado apenas ao MEC. Hoje ele tem que trabalhar com o Ministério da Saúde e com o MEC."

"Nós somos um hospital federal, um hospital de gerência federal, numa gestão municipalizada. Então a gente fica às vezes no limbo, entre Estado e municipio, e às vezes no limbo entre os dois ministérios da educação e da saúde. O que a gente percebe é que a falta de política às vezes é uma politica, e é essa a sensação que a gente tem. Então, a sensação que nós temos em relação às diversas instâncias do poder público é que são nossos parceiros, são nossas relações principais, nossos financiadores, mas vivemos momentos de busca de parceria, momentos de tensão, muito em virtude da questão do financiamento que tem sido insuficiente, tem sido problemática e em cima da questão de pessoal"

Entretanto, a relação com o municipio é muitas vezes conflituosa devido às

necessidades e visões diferenciadas dos novos parceiros;

"O hospital não admitia de jeito nenhum que as consultas dele fossem controladas pela central. Agora, parte é controlada, quer dizer, espontaneamente houve esse movimento. Que ainda é criticado, porque isso, infelizmente, leva a distorções também graves, leva a distorções de encaminhamentos incorretos, que não são triados corretamente, pessoas que marcam e não vêm. Houve problemas, por exemplo, na obstétricia de pacientes de pré-natal que passaram a não ir, ai os alunos também ficaram sem a oportunidade de ter um número significativo de pacientes. Houve problemas. Por exemplo, pequenas cirurgias aqui na oftalmologia foram capturadas pelo sistema de pressão de lobby das clínicas oftalmológicas e aqui está fazendo muito menos do que fazia antes, quando ele tinha uma clientela própria, vamos dizer assim, que ele determinava. Então, tem problemas, e ai foi uma coisa que eu não posso dizer que foi benéfica não, mas foi um movimento político proposital de aproximação do SUS e aproximação do sistema municipal." 
"O financiamento do hospital, que antes era responsabilidade exclusiva do $M E C$, ele passa a se relacionar com a gestão municipal quando ela é plena. Essa gestão municipal nem sempre tem uma visão do hospital universitário que corresponde à visão interma que a gente tem de um hospital universitário, mas eles são os determinadores de teto, de financiamento mais próximos do hospital, então, a gente tem que estar negociando direto com eles".

As relações internas, com a Reitoria e as Unidades Acadêmicas estão mais próximas e ampliando suas atuações no HC. Com o sindicato a relação estaria um pouco tensa devido à percepção diferenciada em relação à inserção do HC no SUS e o achatamento salarial. No entanto, não chega a ser externamente conflituosa, pois as reivindicações salariais dos servidores estatutários são dirigidas ao MEC e a dos celetistas à FUNDEP;

"Agora, em relação à universidade em si acho que foi um avanço enorme. Eu acho que o símbolo desse avanço foi uma coisa que nunca havia sido admitida pela universidade, que é a presença do diretor do HC no Conselho Universitário. Não existia, nunca existiu, nunca foi membro do $\mathrm{CU}$ (...). Havia muita desconfiança da universidade como um todo em relação ao hospital, como se fosse um sorvedouro ilimitado de recursos, que era um perigo, que o hospital era um perigo. (...). Agora eu sinto claramente que o hospital agora é considerado como um pedaço da universidade, e não simplesmente um apêndice. Isso mudou muito"

"Com relação ao sindicato, acho que existe uma relação que é um pouco tensa também, em cima de basicamente duas coisas: em cima de uma visão de eficiência e eficácia que não coincide, a visão da diretoria com o sindicato, mas acho que ela pode ser trabalhada e em virtude também das questões salariais, nesses seis anos sem aumento. Na parte da FUNDEP também temos tensões salariais, porque nós não estamos dando conta de dar aumento em virtude das dividas do hospital. Tem essas duas vertentes de discussão, de disputa que eu acho que é a vertente salarial e a vertente da visão sobre nossa inserção, nosso papel dentro do SUS, dentro do sistema de saúde e nossa obrigação nesse sistema de saúde."

"Com o sindicato, tanto dos professores quanto dos funcionários, a relação é de um lado harmônica, porque o grande empregador é - govemo federal, então quando a gente tem reivindicações, atritos, greves, as greves não são contra o hospital, contra a universidade. Tanto é que as greves que eu participei como professor ou como diretor você não tinha muito o que negociar 
com os grevistas. Você negociava era como fazia para o hospital funcionar e tal, mas as reivindicações deles eram quase todas, sempre foram quase todas, reivindicações junto ao governo federal. Eles iam a Brasilia fazer a negociação. Com os professores, a mesma coisa."

A alternativa de disponibilizar leitos para o setor privado de saúde, teria uma dupla função aumentar a receita e ser um atrativo para a fixação de professores/médicos no HC. O Hospital passa, assim a competir com os provedores privados;

"Tem havido um aumento nessa linha de financiamento e há um interesse desse setor privado no hospital. Basicamente por se tratar de um hospital universitário, que tem uma relação aparentemente ou teoricamente, pelo menos, mais honesta com a questão do faturamento, que tem também uma indicação mais precisa. Existe uma visão ética diferente por parte desses compradores de senviço do hospital universitánio. Talvez seja interessante que a gente se aproveite disso. Nessa linha nós temos conseguido aumentar um pouco esse papel dos financiadores privados. Por outro lado eles são importantes, também, para a fixação do profissional médico no hospital. Como o salário do professor é muito abaixo de mercado para alguns profissionais especialistas que tem no hospital e a gente não tem condição de fazer uma complementação salarial a contento, a forma de muitos desses profissionais se fixarem no hospital é poderem atender, também doentes do setor privado. $E$, o que acontece, é um tipo de acordo no qual ele atende o setor público, ele é obrigado a atender o setor público, e fazendo isso ele faz jus a poder atender ao setor privado."

"O setor privado enquanto você não ameaça, ele é muito tranqüilo. Quando você começa a fazer atividades em áreas que competem com ele, aí ele começa a ficar um pouco incomodado. Agora, como o hospital atende ainda $90 \%$ rede SUS, como os hospitais privados de qualidade sairam todos do SUS, então a gente acaba não sendo competidor deles. A experiência mostra para a gente que naquelas poucas situações em que a gente passa também a disputar mercado com o setor privado ele fica incomodado. Até porque tem todo o prestígio, o nome do $H C$, a qualidade que é reconhecida, faz com gere que, então, esse atrito entre eles." 
Na Tabela 30 vemos os valores mais relacionados ao conceito de eficiência, pelos diretores e ex-diretores do $\mathrm{HC}$.

TABELA 30 - Valores correlacionados ao conceito de eficiência pelos diretores e ex-diretores do Hospital das Clínicas/UFMG

\begin{tabular}{|l|l|}
\hline \multicolumn{2}{|c|}{ Eficiência } \\
\hline Atendimento correto, necessário & Resolutividade; \\
Competência & Cumprir a missão institucional \\
Fazer com rapidez e no prazo proposto & Satisfação do usuário; \\
Resultados & Tempo (de espera, de tratamento) \\
Eficaz & Trabalho concluído \\
Otimização & Participação \\
Menor custo & Chegar a um ponto definido \\
Qualidade & Seriedade; \\
Relação custo beneficio & Redução de custos \\
Compromisso & Virtude \\
Descentralização & \\
\hline
\end{tabular}

Fonte: Dados de pesquisa primária: entrevistas

O conceito de eficiência referido pelos diretores mostra, por um lado seus aspectos econômicos mais marcantemente reconhecidos, por outro, novos atributos são incluídos.

"Eficiência para mim é você conseguir o seu resultado, que se propõe, no menor custo, tanto do ponto de vista financeiro quanto do ponto de vista de utilização de recursos disponiveis."

"Eficiência, é negócio complicado da gente definir. Eu acho que eficiência é quando você tem um norte a seguir, determina todos os parâmetros para atingir aquele norte $e$, na tentativa de atingir o norte, você atinge o mais rápido possivel, com o menor prejuizo possivel e com um ganho aumentado."

"A eficiência, você compara situações de eficiência, você é mais ou menos eficiente se você com o mesmo custo, com o mesmo instrumento, com a mesma estrutura você consegue melhorar os indicadores de eficiência." 
Os atributos de tempo (rapidez, fazer dentro do prazo, ágil) assim como o de

qualidade e de participação são novamente focalizados;

"Para mim, além de conter o conceito de máximo de resultados para um determinado volume de recursos, que seria a eficiência econômica, vamos dizer assim, ela também, se ela for só esse conceito ela é muito pobre. Eu acho que o conceito de eficiência pressupõe também a questão da qualidade, quer dizer, no caso especifico do hospital, aquilo que é investido tem que render mais do ponto de vista do que é atendido, mas ai tem que estar implícita também qualidade, não pode ser só o conceito econômico. Eu acho que tem o conceito de qualidade também embutido aí. Eu acho que o conceito de eficiência pressupõe uma outra coisa também. Se for só a eficiência sem participação, só uma eficiência gerencial, ela é também ineficaz. Ela pode surtir efeito durante um certo tempo, mas se esvai. Por exemplo, esse projeto de unidade funcional, se ela não for tomada pelas pessoas, quer dizer, se essa eficiência não for também a eficiência da participação democrática das pessoas, realmente de participar do processo, ela se esvai. A eficiência, então, automaticamente, pressupõe, está embutido nele um conceito de participação - não sei se eu poderia chamar de democracia, mas de participação.

Os diretores e ex-diretores, também, contextualizam a eficiência às

condições reais na qual ela é produzida ou à missão que se busca;

"O exemplo que a gente pode dar é que nos hospitais federais, onde se comparou UFMG com Federal do Rio Grande do Sul, onde a folha de pagamento é CLT, uma enfermeira ganha lá 3 vezes o que ganha num hospital daqui, e para o mesmo cargo comissionado ela ganha 10 vezes, então uma pessoa dessa vai ficar tempo integral no seu trabalho. Nós chegamos a dizer ao ministro que se nos era cobrada a mesma eficiência de lá, que se aplicasse o mesmo salário. Eles falaram que isso não seria possivel, porque lá era uma situação particular. O que nós dissemos é que se lá era uma situação particular não deveria ser comparada com os demais. Esse, o Hospital Nossa Senhora da Conceição, aqueles hospitais que são dados como exemplo, mas tem um recurso próprio ao nivel do orçamento. Então essa idéia de eficiência na verdade é uma distorção, é uma visão quase ao nivel de Maquiavel, porque você não dá nada e quer tudo. Então essa é a eficiência que eu vejo que é cobrada pelo governo da instituição."

"Porque a eficiência para mim não é só a ideal, é aquilo que a gente consegue fazer, também, dentro dos limites que a gente tem. Então, nesse sentido ele é eficiente. Pode melhorar? Muito, 
mas eu acho que ele é eficiente, sim. Tem um monte de problema, claro, mas ele produz. Ele dá uma assistência boa, ele permite o ensino bom em várias áreas, tem essa abertura, permite que várias pesquisas sejam desenvolvidas aqui, várias atividades. Então, isso para mim é eficiência."

Os entrevistados identificam o conceito de eficiência contido na proposta de reforma de Estado como reducionista, excessivamente econômico, voltado somente para a redução de custos, apesar de colocar como objetivo o atendimento, com maior qualidade, ao cidadão. A maioria dos diretores e exdiretores disse que no $\mathrm{HC}$ não haveria como reduzir o volume de recursos abaixo do despendido atualmente.

“Essa definição é só de papel, na minha opinião, porque na verdade o que eles realmente definem como eficiência eu acho que não tem a ver com qualidade, não. Eles querem com o menor recurso possivel produzir o maior efeito possivel sob o ponto de vista de números. $\dot{E}$ isso que interessa, saber se realmente atendeu mais pacientes, produziu mais alta, etc"

"Eficiência, ela mesma em si, não vejo nada de ruim. Eu acho que um atendimento tem que ser eficiente, qualificado e produzir um bom resultado, só que o que eu sinto na forma como essa reforma é colocada para a instituição, a idéia de eficiência é produzir mais com menos recursos, então, há uma distorção. Acho que a instituição tem que ser eficiente tem que ser eficaz, ela tem que ter uma qualificação, ou seja, ela utiliza dinheiro público e tem que dar um retomo para a sociedade. Agora, a eficiência do jeito que é passada ela só quer ter uma produção maior (...)."

"Eu acho que é possivel racionalizar, você gastar da melhor forma possivel o dinheiro público. Agora, eu não sei se dá para fazer mais com menos dinheiro do que a gente está usando. Eu vejo que os aspectos centrados no cidadão, na qualidade, mesmo o aspecto custo é importante, é necessário, mas não saberia dizer se no caso especifico do $H C$ há espaço para redução de recursos."

Um entrevistado chama atenção para a contradição existente entre a tabela de procedimento do SUS (que determina a média de permanência de cada procedimento) e as inovações tecnológicas que estão reduzindo 
drasticamente esta taxa. Segundo ele esse conservadorismo estaria acarretando maior ineficiência;

"Por outro lado, há um emperramento enorme que não acompanha a tecnologia. Vou tentar clarificar, também. Hoje com as novas técnicas de cirurgia, com vídeo, a pessoa pode ser intemada e liberada rápido. Só que o SUS fala que para um procedimento $A$, a pessoa tem que estar hospitalizada $X$ dias. $E$ todas as cirurgias que assim foram realizadas elas não foram pagas. Nós estamos vivendo uma contradição entre a modemização e a legislação. $E$ até agora não conseguimos mexer nessa parte, porque eu sei que os me sucederam não conseguiram intervir nessa parte, também. Ou seja, a própria eficiência da instituição foi punida."

A eficiência do HC é uma questão bastante controversa entre os entrevistados. Alguns afirmam que inegavelmente ele é eficiente no ensino, pesquisa e na qualidade da assistência que traz satisfação à população nele atendida. Outros dizem que ele não é eficiente nem na qualidade de atendimento. Todos parecem concordar que ele não seria eficiente nos aspectos gerenciais e financeiros, mas que está melhorando;

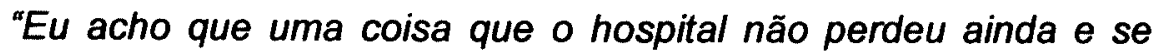
continuar com a dedicação do corpo clínico, do corpo de enfermagem é a questão da qualidade da atenção. Porém, eu não tenho segurança para the dizer que essa assistência é prestada com a racionalização necessária que deve ter da questão do custo. Então, não poderia lhe dizer que o hospital é eficiente hoje. Eu precisaria de mais dados, ter controle sobre mais processos e a gente está buscando isso."

"Na verdade, não diria eficiente, diria até meio mágico (...). Então, era muito mais uma relação afetiva que levava a uma certa produção. Havia um compromisso entre as pessoas e a instituição. Esse compromisso foi sendo diluído com a perda do poder aquisitivo dos funcionários, a mudança estrutural, a mudança administrativa da instituição e hoje o hospital está pouco eficiente, embora tenha melhorado vários fatores mais especificos de faturamento, de informação, ele está sendo menos eficiente do que ele já foi há pouco tempo. Ele tem perdido progressivamente a sua qualidade de atendimento." 
Para a maioria dos entrevistados o HC é mais eficiente hoje do que no início dos anos 90 , sendo que os principais motivos foram sua maior inserção no SUS e as limitações de recursos financeiros impostas pelo governo federal, o que teria levado a maior preocupação com a redução dos desperdícios, e com os custos, etc. No entanto existem vozes discordantes.

"Com certeza, não tenho dúvida disso. Eu acho que o acesso do paciente ao hospital está muito maior, a inserção dele no sistema de saúde está muito maior. (...) Nós agora não fazemos o que queremos. A gente até preserva um certo grau de autonomia em alguns setores, que é necessário, mas a gente está inserido em um sistema e está atendendo a esse sistema. Então, acho que nós somos muito mais eficientes do que há alguns anos atrás, não tenho dúvida disso."

"Então, se você pensar em número de atendimento, complexidade de atendimento, até na melhoria do ensino - até porque aumentou o número de procedimentos, aumentou o número de atendimento, criou-se o pronto atendimento, criou-se unidade de transplante, quer dizer, tudo isso gera uma eficiência maior não só no atendimento como também no ensino e pesquisa."

"Ele está perdendo sua eficiência enquanto qualidade de atendimento. Ele está sendo pressionado a dar altas precoces, ele tem menos recursos para trabalhar, porque antes ele tinha suplementaçőes orçamentárias que permitia investir. Hoje está sendo cobrado muito do hospital ter um volume de atendimento grande, ter uma economia de escala, que é até saudável, ou seja, apagar uma luz, gastar menos água. Mas, por outro lado, as relações humanas dentro do hospital foram destruidas, com isso a motivação institucional caiu e caiu brutalmente. (...)"

É majoritário entre os diretores e ex-diretores que o principal entrave para que o $\mathrm{HC}$ se torne um hospital eficiente seria um maior aporte de recursos financeiros, ou como disseram alguns, maior compromisso do governo com a educação e saúde. Estes recursos poderiam ser utilizados na recuperação predial, na compra de equipamentos mais modernos e até mesmo na remuneração dos servidores; 
"Agora, tem alguns setores que ainda dependem de recurso, dependem de equipamento. Eu acho que tem alguns setores que dependem até de remuneração melhor. A gente perde pessoal para o setor privado com muita freqüência, porque às vezes a gente treina um profissional aqui e ele sai, vai para o setor privado. Eu até não tinha feito nenhuma observação a esse respeito ainda, tinha ficado mais na questão da visão, da gestão, mas eu acho que tem problema de financiamento também. Eu não quero é ficar chorando, normalmente eu não faço isso, sobre essa questão do financiamento. Mas tem problema de financiamento também. Tem problema de remuneração, tem obsolescência de equipamento, então investimento é uma coisa problemática. A degradação predial ela é muito grande, a gente não consegue fazer investimento em manutenção predial. Então, tem diversos gargalos do ponto de vista também financeiro."

Outros, no entanto apontam aspectos culturais, a antiga visão de serviço público, a falta de comprometimento dos trabalhadores;

"(...) as pessoas que trabalham no hospital terem esse entendimento, de que isso é um óngão publico e ai voltando à frase anterior que o cidadão é que é o dono desse botequim, ele tem que ser dono, o centro tem que ser ele, o hospital tem que ser orientado para ele, desde horário de funcionamento, horário de visita, perfil de atendimento, tudo para ele. Então se o estado se responsabilizasse mais, priorizando e investindo, dando força para que os hospitais públicos e se as pessoas que trabalham nesse setor entenderem isso, e realmente assumirem isso como responsabilidade dele, eu acho que seria um caminho interessante para o hospital cada vez mais se tornar mais eficiente.;

"Cultura organizacional, do lidar com o público. Quando $100 \%$ ou próximo disso, das pessoas que circulam aqui dentro, lidarem com o público como se estivesse na casa dele, com o espirito de redução do desperdicio e do cuidar, do zelar pela instituição, esse eu acho que é o principal"

A necessidade de maior autonomia de gestão, financeira, de recursos humanos, de remuneração, de compras de material também foi levantada como entrave à eficiência do HC;

"Os entraves são de vánios niveis. Primeiro ele precisa, dentro dessa idéia de eficiência, uma certa flexibilidade administrativa. $O$ hospital tem um orçamento amarrado. Na verdade ele recebe um recurso, mas a capacidade de utilização desse recurso é muito presa, ou seja, ele não tem a capacidade de genir esse recurso de 
forma adequada a nivel de poder contratar pessoal, de oferecer um salário digno para essas pessoas, de valorizar e treinar os seus recursos humanos, de capacitar a instituição a nivel de aparelhagem, de modemizar sua estrutura física. (...) Então, na verdade é como se eu estivesse falando para você o discurso da organização social. Mas antes quando o hospital era CLT, e/e podia fazer essa situação, ou que fosse estatutário, mas que o hospital tivesse uma capacidade de fazer concursos públicos, transparentes, mas com uma folha de salários compativel com o mercado, que ele pudesse pagar de uma forma adequada o seu funcionário. O recurso humano move a instituição. Então, não adianta você treiná-lo, que ele vai ser treinado e partir para a rede privada."

As soluções seriam ter mais recursos financeiros, seja através do orçamento seja pela melhoria da tabela de pagamento do SUS. Outra solução importante seria maior participação e compromisso dos trabalhadores com a definição das necessidades e soluções para o HC;

"A solução que nós estamos imaginando é uma participação de todos na gerência e no compromisso de manter a instituição. Nós estamos jogando peso nas unidades funcionais, onde as pessoas, cada um vai ter, eu acho, que o sentimento, com a descentralização, que a viabilidade da sua área vai ser a viabilidade do hospital como um todo. (...) E o que eu estou falando, o recurso é pequeno, o gestor tem problema, nós temos problema. Alguns são resolvidos, mas você tem um limite, depois de um determinado limite só com a participação de todos. Eu acho que o limite está muito claro, a gente não consegue avançar mais nele a não ser com a descentralização."

"É recuperar, realmente, essa discussão. Um negócio cuidadoso. Sentar e discutir: o que nós somos? O que queremos ser? É um hospital universitánio? Vamos concordar que um hospital universitário é um substantivo composto, porque nós temos compromissos especiais? Qual é o mecanismo para desenvolver essa proposta - tem parte administrativa, tem política, tem planejamento, relação com a universidade, relação com a Faculdade de Medicina, relação com os estudantes. Tem que compor o hospital. (...) Vamos colocar as questões na mesa e discutir a instituição. Vamos redefinir, recuperar a história, e redefinir a questão atual. Nós queremos ser hospital universitánio como substantivo composto? É uma idéia chave. Então, quais são os mecanismos para isso?"

Para os diretores e ex-diretores um hospital público pode ser eficiente e

pode, também, continuar público desde que tenha clara qual é sua missão. 
Ponto comum é o reconhecimento de que o hospital público eficiente não alija a necessidade de suporte financeiro por parte do Estado;

"A questão é você compatibilizar isso com a missão que você acha que o hospital deve ter. Então o grande risco é esse aí, se você colocar a questão da eficiente e não entender claramente qual é sua meta, seu objetivo e não ligar as duas coisas uma a outra, você toma as coisas deformadas, que eu acho que é como as Pioneiras Sociais, que tem um recurso enorme e qual a importância dela no sistema de saúde?"

A importância de um hospital público ser eficiente é que ele precisa dar respostas aos seus usuários, à população que o mantém. Pode ser, até mesmo, pela necessidade de sobrevivência em meio à redução de financiamento público. É por isso que se torna fundamental que as diversas instâncias governamentais também tenham esta visão;

"Não tenho dúvida, acho que não só é importante como é fundamental. (...) Qualquer organização que visa atender ao público que esteja voltada mais para si do que para o público, me parece que tem alguma coisa nela que está pervertida, e ela não se sustenta socialmente. O que vai dar respaldo social e político para nossa instituição que não seja sua importância social, que não seja o trabalho dela, que não seja o uso adequado que ela faz dos recursos públicos? Por fim, o que vai dar respaldo político e social para o próprio setor público funcionar, para as próprias instituições públicas, se não for a própria eficiência delas? Eu penso que não dá para não discutir eficiência."

“(...) Então, é fundamental para o Estado brasileiro, para a nação brasileira, garantir que os hospitais públicos sejam locais de eficiência, que sejam instituições eficientes, que seja uma atuação política para contrapor, para que a população tenha uma referência de que é possível outro modelo de atenção à saúde que não seja esse, puramente financeiro, onde os hospitais são organizados de acordo com o planejamento financeiro das seguradoras. Pelo contrário, os equipamentos da saúde devem ser organizados de acordo com a necessidade da população."

Ponto recorrente em várias falas das entrevistas foi a necessidade de se levar em consideração a especificidade do $\mathrm{HC}$ como hospital de pesquisa e formador de recursos humanos. Portanto, como tem vários objetivos a 
medida de sua eficiência também teria que considerar estas particularidades.

“(...) Não tem como falar que você está deficiente porque está atendendo três consultas por manhã, tratando-se de alunos de $5^{\circ}$ periodo, onde o professor tem que fazer um esforço danado para poder esse rapaz sair no final do semestre, minimamente preparado, para entender que o mundo tem vários significados. $\mathrm{Na}$ área do relacionamento dele com outras pessoas, ele tem que entender o significado do outro, a significância do outro e a dele, para fazer a correlação com a medicina. Isso é trabalhoso. Qual é a eficiência disso? A eficiência disso é só medida no resultado do estudante."

Todos os diretores e ex-diretores afirmaram que o conceito de eficiência compreenderia os valores de qualidade, cidadania e responsabilização. E que um hospital público deveria ser eficiente, ter qualidade em suas atividades e ser compromissado em dar respostas à população;

"É o cidadão, na verdade, que é o principal avalisador da eficiência. Eu tenho a impressão que uma instituição não se sustenta socialmente sem eficiência. O público hoje sabe muito bem o que é eficiência e cobra isso de forma muito clara, às vezes até de forma exagerada, de forma dramática, mas ele sabe e quer isso. Não cabe mais a gente ficar gastando de forma ineficaz o recurso público, não justificando, não tendo transparência $e$ principalmente, não melhorando o acesso, não retomando para a sociedade o que recebemos em termos de recurso e os conhecimentos que são gerados dentro do hospital. Acho que a eficiência é para a cidadania, e a eficiência não é para outra coisa, ela fora do contexto da cidadania não tem sentido nenhum."

"Tudo que a gente busca hoje no hospital é que as pessoas tenham compromisso com o seu processo de trabalho e com o resultado final do seu trabalho. Até em nosso projeto gerencial que estamos desenvolvendo no hospital, o ponto básico, o ponto chave é a responsabilização. Nós não podemos mais ter uma pessoa que chega na ponta do guichê e fala: o senhor volta outro dia para pegar ficha. Não estou dizendo que isso não aconteça, mas nós temos que acabar com isso e caminhar para outro patamar, outro paradigma. Essa questão da responsabilização tem haver com cidadania, tem haver com eficiência, eu acho, também, que a única forma que a gente tem de melhorar isso por isso eu falo que esse acordo politico tem que melhorar em algum momento - se os atores não estiverem pensando que aquela pessoa que está demandando um serviço é um igual, ou 
pelo menos está submetido a contingências que um dia ele também vai estar submetido a elas, que tem necessidades $e$ direitos, nada vai funcionar, não adianta nada."

Podemos ver na Tabela 31 uma síntese dos valores associados ao conceito de eficiência encontrados nos documentos do $\mathrm{HC}$ e nas falas de seus trabalhadores, gerentes e diretores em relação aos valores contidos na proposta do MARE. Vemos que valores mais universais como atender as necessidades da sociedade, o atendimento ao cidadão/clientes - que nos serviços de saúde é apreendido como usuário - ter qualidade, responsabilização, ser profissional e participação são consensuais. Ademais notamos que atribuições gerenciais altamente valorizadas como eficientes no ideário da reforma, como por exemplo, autonomia, descentralização, avaliação desempenho, redução de custos, otimização e controle dos resultados, também são unânimes entre os trabalhadores e gerência do HC. Por outro lado, a intima correlação entre governança e eficiência encontrada nos documentos do MARE não é sequer vislumbrada ou mencionada por trabalhadores, gerência e mesmo nos documentos do HC. 
TABELA 31 Valores correlacionados ao conceito de eficiência nos documentos do MARE, HC e pelos trabalhadores, gerência intermediária e pelos diretores e exdiretores do Hospital das Clínicas/UFMG

\begin{tabular}{|c|c|c|c|c|}
\hline MARE & Textos HC & Trabalbadores & Gerência & Diretoria \\
\hline $\begin{array}{l}\text { Atender as } \\
\text { necessidades da } \\
\text { sociedade }\end{array}$ & $\begin{array}{l}\text { Retorno para a } \\
\text { sociedade }\end{array}$ & Coletividade & $\begin{array}{l}\text { Prestar um bom } \\
\text { serviço }\end{array}$ & $\begin{array}{l}\text { Atendimento correto } \\
\text { e necessário }\end{array}$ \\
\hline $\begin{array}{l}\text { Atendimento do } \\
\text { cidadão/cliente }\end{array}$ & & $\begin{array}{l}\text { Satisfação do } \\
\text { paciente }\end{array}$ & $\begin{array}{l}\text { Satisfação do } \\
\text { usuário }\end{array}$ & $\begin{array}{l}\text { Satisfação do } \\
\text { usuário }\end{array}$ \\
\hline Aumento qualidade & Qualidade & Qualidade & Qualidade & Qualidade \\
\hline Autonomia & Autonomia & & Autonomia & Autonomia \\
\hline $\begin{array}{l}\text { Avaliação de } \\
\text { desempenho }\end{array}$ & $\begin{array}{l}\text { Avaliação de } \\
\text { desempenho coletiva }\end{array}$ & Produtividade & Desempenho & Produtividade \\
\hline \multicolumn{5}{|l|}{$\begin{array}{l}\text { Competição } \\
\text { administrada }\end{array}$} \\
\hline $\begin{array}{l}\text { Conhecimento da } \\
\text { missão institucional }\end{array}$ & $\begin{array}{l}\text { Conhecimento da } \\
\text { missão institucional }\end{array}$ & & Conscientização & $\begin{array}{l}\text { Cumprir a missão } \\
\text { institucional }\end{array}$ \\
\hline Controle resultados & Resultados & Resolutividade & Melhor resultado & Resolutividade \\
\hline Controle social & Conselho Usuários & & & \\
\hline $\begin{array}{l}\text { Definição clara de } \\
\text { objetivos }\end{array}$ & Definição de metas & Objetividade & & \\
\hline \multicolumn{5}{|l|}{ Democrático } \\
\hline Descentralização & Descentralização & Descentralização & Descentralização & Descentralização \\
\hline Equidade & Equidade & & & \\
\hline \multicolumn{5}{|l|}{$\begin{array}{l}\text { Flexivel e } \\
\text { flexibilidade }\end{array}$} \\
\hline Gerencial & Gerência moderna & & & \\
\hline \multicolumn{5}{|l|}{ Govemança } \\
\hline \multicolumn{5}{|l|}{ Informação } \\
\hline \multicolumn{5}{|l|}{ Mercado } \\
\hline Otimização & Otimização & Otimização & Otimização & Otimização \\
\hline Participação & Participação & Participação & & Participação \\
\hline Profissional & Competência & Profissional & Profissional & Competência \\
\hline \multicolumn{5}{|l|}{$\begin{array}{l}\text { Punição para os que } \\
\text { prevaricarem }\end{array}$} \\
\hline \multicolumn{5}{|l|}{ Racional } \\
\hline Redução de custos & $\begin{array}{l}\text { Redução de custos } \\
\text { Relação custo- } \\
\text { benefícios }\end{array}$ & $\begin{array}{l}\text { Reduzir custo } \\
\text { Relação custo- } \\
\text { beneficio }\end{array}$ & $\begin{array}{l}\text { Menor custo } \\
\text { Diminuir os } \\
\text { desperdícios }\end{array}$ & $\begin{array}{l}\text { Redução de Custo } \\
\text { Relação custo- } \\
\text { beneficio }\end{array}$ \\
\hline Responsabilização & Co-responsabilidade & Compromisso - Ética & Comprometimento & Compromisso \\
\hline $\begin{array}{l}\text { Valores e } \\
\text { comportamentos } \\
\text { modernos }\end{array}$ & & & & \\
\hline
\end{tabular}

Fonte: Documentos MARE e HC e entrevistas. 


\section{DISCUSSÃO}

\subsection{A REFORMA DO ESTADO BRASILEIRO (E SETORIAL): ENTRE O "NECESSÁRIO" E O "POSSÍVEL"}

O governo Fernando Henrique Cardoso escolheu quatro principais itens para sua agenda de reformas de Estado - a administrativa, a previdenciária, a tributária e a patrimonial. Estas escolhas não foram arbitrárias, mas condicionadas por uma historicidade contemporânea. A agenda de reformas representa uma escolha de questões tidas como relevantes do ponto de vista da politica e da economia nacional. Para NOGUEIRA (1999) e DINIZ (2000) a escolha desse rol de questões decorreria em grande parte daquilo que é previsto numa agenda que tem extensão mundial e que faz parte das exigências de apoio dos organismos internacionais de financiamento aos planos nacionais de estabilização econômica dos países do Terceiro Mundo. A orientação básica do governo sempre esteve voltada para as questões relativas à crise fiscal e à necessidade de alcançar a austeridade orçamentária (ANDREWS e KOUZMIN 1998; KAUFMAN 1999 apud PIERANTONI 2000; DINIZ 2000).

O ritmo e as formas de implementação também obedeceram a esses condicionantes. A reforma tributária foi postergada, enquanto a patrimonial foi a primeira a ser regulamentada, alcançando recordes no volume de recursos de propriedade estatal transferido à iniciativa privada. A reforma administrativa encontrou-se, igualmente, na categoria de uma exigência premente. Além de estabelecer um novo padrão de relacionamento entre Estado e mercado e, em curto prazo, ela visou uma diminuição do gasto com 
pessoal. Eis porque os dispositivos centrais da reforma consistiram na eliminação dos princípios da estabilidade, da isonomia e do regime jurídico único. Aspectos da gestão de pessoal acabam por serem trabalhados muito mais rapidamente enquanto $\circ$ governo parece sem pressa e até mesmo ambivalente quanto à necessidade de implementar aspectos institucionais, como o das organizações sociais. (ANDREWS e KOUZMIN 1998; NOGUEIRA 1999; DINIZ 2000).

$\mathrm{Na}$ análise dos resultados através das categorias significativas, vimos na categoria organização e estruturação a centralidade da distinção entre os vários núcleos do Estado, suas formas de propriedade e de gestão, ademais da separação entre formulação e execução das políticas regulatórias e sociais.

Para BORGES (2000) se levarmos ao extremo a idéia de um trade-off entre mercado e hierarquia, concluiriamos que a organização burocrática tradicional do setor público deveria limitar-se a funções estratégicas (core functions), não contestáveis, cujos outputs são dificeis de medir (administração da Justiça, segurança externa, arrecadação de impostos etc.). Conforme esta perspectiva, para os serviços altamente contestáveis (a maioria dos bens privados), os mecanismos de mercado com provisão privada (privatização) ou provisão pública e privada (quase-mercados) são os mais adequados. Em uma categoria intermediária, as agências públicas em setores não contestáveis, mas passiveis de medição de performance, devem ser submetidas a controles de resultados, com o fortalecimento de mecanismos de "voz" (pesquisas de satisfação de clientes, comitês de 
usuários etc.). Na ausência de altos custos de transação, as atividades nesses setores podem também ser terceirizadas para empresas privadas e ONGs

Seguindo os ditames da proposta da reforma vai-se instituir, ainda, a separação das politicas regulatórias - que continuariam centralizadas - das atividades de execução e prestação de serviços que passariam a ser descentralizadas. Foi a denominada publicização (transferência de atividades estatais para a esfera "pública não estatal"). Para viabilizar esta nova estratégia de atuação do estado no setor de prestação de serviços e infra-estrutura, além de promover o rompimento como ethos da "repartição pública", o Plano Diretor sugere a criação de um ente jurídico novo, a chamada organização social, que se relacionaria com o órgão formulador/regulador através de contratos de gestão.

Alguns autores (ANDREWS e KOUZMIN 1998; DINIZ 2000; COHN 1999; MELO e TANAKA 2001) têm questionado, a novidade administrativa das OS e dos contratos de gestão, visto que já foram experimentados anteriormente na criação de autarquias e fundações (Decreto-Lei 200 de 1967), quando se adotou o modelo gerencial. Segundo ANDREWS e KOUZMIN (1998) a razão para o fracasso do modelo gerencial, na reforma administrativa de 1967, foi, por um lado a autonomia excessiva - tais agências canalizaram recursos técnicos e financeiros em sua área de atuação, se desvincularam da intervenção normativa dos ministérios e promoveram um esvaziamento das esferas ministeriais responsáveis pela formulação e implementação de politicas públicas. Ademais, a ausência de controle social facilitou a captura 
dessas agências por grupos de interesse privados. Para os autores, o Plano Diretor apresenta a mesma receita de separação entre formulação e implementação de políticas públicas, supostamente para eliminar os mesmos sintomas: rent-seeking ou "uso da máquina pública por interesse privado".

COHN (1999:192) enfatiza que a proposta de gestão dos equipamentos públicos através das OS, deslocaria mais uma vez, a questão social para o espaço da capacidade técnico-burocrático-administrativa do aparato estatal, sobrepondo o cálculo da racionalidade econômica à dimensão política dos direitos e necessidades sociais: questão de "cálculo econômico entre o "possivel" e o "necessário", reduzindo-se assim a esfera pública e, conseqüentemente, a questão social sendo progressivamente expulsa da esfera política."

Para GIRARDI (1998), a ampliação das funções reguladoras em detrimento das funções prestadoras dos governos e dos aparelhos substantivos do Estado, na reforma, coloca problemas especiais para aqueles setores de missão social pronunciada, nos quais, tradicionalmente, a função de provisão pública e planejamento estatal tem sido mais forte, como os setores saúde e educação. Na saúde, a construção de capacidade de regulação reclama do Estado mais que simples capacidade de regulação econômica. Valores e metas finalísticas de justiça social, equidade e promoção de oportunidade - e não apenas o cumprimento de metas eficientistas colocam-se neste setor como parâmetro definidor inarredável das estratégias regulatórias e orientadoras da reforma institucional. 
Especificamente no campo da saúde, a concepção das organizações sociais parece fornecer um fundamento racional em direção a uma administração gerencial flexível, capaz de dar conta das necessidades de articulação com o mercado em geral e com o mercado de trabalho em particular. No entanto, sua funcionalidade gestionária dependeria da articulação de uma rede de unidades que implicasse eficiência e qualidade sistêmicas. Nesses aspectos sistêmicos, devem ser considerados elementos tais como a modalidade de financiamento, o encadeamento entre ações de saúde preventivas e curativas, a hierarquização dos tipos de ação de saúde, a vinculação da clientela, etc (NOGUEIRA e GIRARDI 1997). O que se pode supor aqui é que as organizações sociais definem apenas as pré-condições de uma operação gerencial eficiente e não se enquadram como modelos de gestão, onde a ação coordenada das unidades de produção, em forma horizontal e vertical, são pressuposto para a obtenção de eficiência e qualidade sistêmicas, como no caso da saúde. A proposta parece ater-se à criação de um sistema autônomo de organizações de assistência médica hospitalar (mas não exclusivamente), privilegiando a gestão das unidades hospitalares, em detrimento da gestão do sistema, sob a ótica do comprador de serviços hospitalares. Igualmente, não leva em consideração as dificuldades de gestão e a necessidade de alcançar maior racionalidade na provisão da atenção à saúde no interior de um sistema institucionalmente fragmentado, além de sua inadequação ao objetivo de assegurar o princípio da integralidade da atenção (BARROS 1996; KLIKSBERG 1998, ALMEIDA 1999; PIERANTONI 2001) 
Na categoria significativa "gestão" encontramos que segundo o Plano Diretor a reforma concreta do aparelho de Estado ocorreria na dimensão gestão, baseando-se nos princípios da administração pública gerencial. As doutrinas administrativas que vem dominando a agenda de reformas burocráticas em alguns paises do mundo desenvolvido neste final de século foram agrupadas na expressão "nova administração pública" ou simplesmente "gerencialismo". O gerencialismo combina as reflexōes da nova economia política sobre o Estado à defesa ideológica do modelo de gestão caracteristico do setor privado (POLLIT 1994 apud BORGES 2000). Portanto, sua adoção na reforma do aparelho do Estado brasileiro é visto como contemporâneo e de apelo universal; "A reforma do aparelho do Estado no Brasil significará, fundamentalmente, a introdução na administração pública da cultura e das técnicas gerenciais modernas" (BRASIL 1995:18, Plano Diretor da Reforma do Aparelho de Estado).

A refundação democrática da administração pública estaria na proposta do Estado-empresário, bem como a noção de contratualização das relaçōes institucionais. Portanto, reconceitualização do governo e do serviço público em termos de formas empresariais envolveria a redefinição do social como uma forma do econômico. Assim, o governo deve ser uma empresa que promove a concorrência entre os serviços públicos, centrado em objetivos e resultados, mais que na obediência a regras, deve preocupar-se mais em obter recursos do que em gastá-los; deve transformar os cidadãos em consumidores, descentralizando o poder segundo mecanismos de mercado em vez de mecanismos burocráticos. $\mathrm{O}$ modelo burocrático é considerado inadequado na 
era da informação, do mercado global, da economia baseada no conhecimento e é, além disso, demasiado lento e impessoal no cumprimento dos seus objetivos (SANTOS Boaventura 1999). A glorificação do papel do gerente que atua na busca estrita da eficiência econômica, livre das pressões "irracionais" da política, de maneira análoga, é a grande idéia-força por trás da doutrina gerencialista. Nega-se, dessa forma, o caráter essencialmente político da administração pública e as implicações distributivas das ações do gestor público, que passam a obedecer à racionalidade supostamente superior do mercado.

O que haveria de especifico na crítica atual à burocracia, segundo SANTOS Boaventura (1999), seria a recusa em reconhecer que muitos dos seus defeitos resultaram de decisões que visavam atingir objetivos políticos democráticos, tais como a neutralização de poderes fáticos, a equidade, a probidade e a previsibilidade das decisões, a acessibilidade e a independência dos serviços, etc. $O$ não reconhecimento destes objetivos dispensa a crítica de posicionar-se perante eles, conseqüentemente, de investigar a capacidade da gestão empresarial para os realizar. Nessas condições, a crítica da burocracia, em vez de incidir na análise dos mecanismos que desviaram a administração pública desses objetivos, corre o risco de transforma-los em custos de transação que é preciso minimizar ou mesmo eliminar em nome da eficiência, arvorada em critério último ou único de gestão do Estado. Portanto, peça-chave do gerencialismo é a idéia de uma gestão eficiente, conceito este que passa a orientar a reforma do aparelho do Estado brasileiro; 
"A eficiência da administração pública - a necessidade de reduzir custos e aumentar a qualidade dos serviços, tendo o cidadão como beneficiário - torna-se então essencial. A reforma do aparelho do Estado passa a ser orientada predominantemente pelos valores da eficiência e qualidade na prestação de serviços públicos e pelo desenvolvimento de uma cultura gerencial nas organizações" (BRASIL 1995. Plano Diretor da Reforma do Aparelho de Estado, p.10).

$\mathrm{Na}$ análise da categoria "público" observamos a utilização da metáfora cidadão/cliente e cliente/consumidor. Para MISOCZKY (2001) as metáforas do cliente e do consumidor somente poderiam ser aplicadas aos indivíduos integrados, portadores de direitos. Não se aplicariam a grupos sociais que são excluídos do mercado consumidor, seja pela condição de pobreza ou por preconceito ou por ambas as situações. Nestes contextos segundo a autora, somente a categoria cidadania (ainda que almejada) pode apoiar a compreensão do papel da administração pública e das possibilidades de ação participativa para o desenvolvimento de políticas inclusivas. SCHACHTER (apud MISOCZKY 2001) afirma que o governo precisa servir a todos, e não apenas aos consumidores imediatamente óbvios.

Uma variedade de termos tem sido utilizada para descrever aqueles que recebem serviços públicos, geralmente de modo intercambiável e sem se preocupar com os significados: clientes, usuários, consumidores e público. Segundo MENDES (2001) geralmente, quando há dependência dos profissionais para prestar um serviço, usa-se o termo cliente, no entanto nos serviços sociais (saúde em especial) é mais comum o termo "usuário". A denominação "consumidor" é usada para expressar relações de troca com pagamento pelo serviço (como os serviços de água e luz). 
Do ponto de vista político a democratização e maior participação se daria, tanto pelo processo de descentralização como pela participação direta dos cidadãos/clientes na gestão das OS. A descentralização se constituiria em possibilidade de maior aproximação "fisica" entre Estado e cidadão. Esta maior aproximação teria, também, uma racionalidade econômica, ao adaptar com eficiência os serviços sociais às reais necessidades da população. No plano organizacional os cidadãos/clientes teriam participação nos Conselhos de Gestão das OS. COHN (1999) reconhecendo a importância de espaços institucionais de participação na implementação e formulaçăo de políticas sociais aponta a contradição deste processo na realidade brasileira. Pois estes espaços institucionais tendem a ser ocupados pelos setores mais organizados os incluídos - da sociedade, dificultando a presença de representações dos "cidadãos/clientes menos óbvios". Ademais as experiências de co-gestão e participação em colegiados apontariam para uma relação de externalidade entre sociedade e o Estado, em que o Estado é apontado quase sempre como o responsável pela provisão. Ao fomentar o repasse das funções estatais para organizaçōes privadas (sejam empresas ou ONGs), entretanto, a reforma gerencial apenas substitui a burocracia pública pela burocracia privada, sendo que a segunda não está sujeita aos mecanismos de checks and balances da democracia representativa (BORGES 2000).

$\mathrm{Na}$ análise da categoria "financiamento" poderiamos dizer que no financiamento das políticas sociais é explicitada a lógica da subordinação do princípio de equidade aos da eficiência, efetividade e economia dos gastos públicos. A partir desta lógica é que se insere a preocupação com a seletividade e focalização 
das políticas de proteção social (COSTA 1998). É o que COHN (1999) denominou de "segunda geração de privatização dos serviços sociais" e que consiste não mais em que os recursos públicos comprem serviços produzidos pelo setor privado, mas exatamente em se transplantar para o interior do setor público estatal critérios e práticas de seletividade próprias de mercado. Para que essas contenções não se traduzam em cortes de determinados serviços e ações mais onerosas, seria necessária a garantia de efetivos mecanismos de controle público, que impedissem a seletividade de clientela ou de demanda.

Esta percepção é reforçada por COOPER (1998) ao destacar que as abordagens atuais de redução de recursos adotam um modelo relativamente simplista de eficiência de insumo/produtos. Crescem as tensões associadas à restrição de recursos, sobretudo dada a tendência das ações de longo prazo perderem terreno para as açōes de curto prazo voltadas à sobrevivência, já que a natureza dos orçamentos está mudando. Observa-se nas organizações públicas o movimento de mudança de orçamentos vinculados, para orçamentos agregados, nos quais são orientadas a achar novas alternativas de financiamento (taxas, multas, encargos aos usuários dos serviços ou a venda de serviços), e não mais esperar orçamentos adequados para satisfazer suas exigências financeiras. Um dos perigos de tal mudança, evidentemente, seria acentuar as desigualdades existentes, já que mesmo taxas relativamente pequenas podem excluir as pessoas mais pobres. Talvez mais perigoso ainda seja o fato de que esta abordagem faz com que os contribuintes considerem a política pública como se fosse uma taxa para um determinado serviço em uma 
determinada situação, em vez de a considerarem como um conjunto de determinações que concerne ao que é melhor para a nação como um todo.

Segundo KAUFMAN e SEGURA-UBIERGO (2001) as pronunciadas restrições que a globalização e as reformas parecem impor às transferências de seguridade social não se estendem aos gastos com saúde e educação. Possivelmente, como os setores de saúde e educação abrangem um conjunto mais amplo de interessados, as decisões sobre o gasto nessas áreas parecem refletir uma lógica política distinta, muito mais vinculada à concorrência eleitoral e à participação política.

As relações de trabalho vão ser marcadas pela quebra da estabilidade, pelas relações contratuais e pela avaliação de desempenho. Da mesma forma que na reestruturação do Estado brasileiro foi instituída a separação entre formulação e provisão de bens e serviços, na organização do trabalho vai acontecer a mesma polarização entre concepção e execução. Assim, teríamos um "núcleo duro" ou "core" em carreiras bem estruturadas com trabalhadores altamente qualificados, assalariados, estáveis e bem remunerados, "Esses senvidores representarão o Estado enquanto pessoal (...) O novo papel do Estado pressupõe, assim, o fortalecimento das carreiras voltadas para a formulação, controle e avaliação de políticas públicas, bem como, para atividades exclusivas de Estado" (BRASIL 1997, Cadernos do MARE c.11). Na outra ponta, teriamos uma força de trabalho mais instável, com uma gama variada de direitos trabalhistas, com contratos por tempo determinado, parcial e até mesmo sem vínculo nenhum, como os terceirizados. Seria a implantação, na administração pública, do mesmo 
dualismo do mercado de trabalho e da sociedade em tempos de globalização, reformas do Estado e flexibilização das relações de trabalho (PIORE e SABEL 1984). No entanto, para ambos os extremos, a mesma perspectiva gerencial é imperativa: a necessidade de avaliar a produção de cada um, sua quantidade e qualidade. Como observa NOGUEIRA (1999), a avaliação de desempenho (com sua correspondente escala de remuneração adicional) é incorporada com destaque aos instrumentos disponiveis de desenvolvimento de recursos humanos, numa perspectiva de criar um ambiente de competição entre os funcionários. Podemos notar que para as várias carreiras regulamentadas ou criadas, dentro da reforma do Estado, já vem determinado que as gratificações serão proporcionais ao resultado das avaliações de desempenho individual e ao cumprimento de metas institucionais.

BORGES (2000) argumenta que a insegurança criada por formas flexiveis de trabalho (precarização de contratos, fim das carreiras tradicionais etc.) acaba por corroer os valores de confiança, comprometimento e lealdade que caracterizavam as relações entre empresas e empregados durante a era fordista. A sensação de que "não há longo prazo" no contexto do novo capitalismo impede que as pessoas consigam estruturar suas vidas como uma narrativa coerente, incentivando o comportamento orientado para o curto prazo e desprendido de valores éticos firmes que se supõe caracteristico do empreendedor de sucesso na atualidade. As reformas gerenciais, ao apostarem na quebra da estabilidade no emprego, em contratos de curto prazo e formas organizacionais flexiveis, correm assim o 
risco de solapar o senso de missão e comprometimento que deveria caracterizar as organizações públicas.

Em análise sobre a experiência da implantação da nova administração pública na Nova Zelândia, Noruega e Austrália, CHRISTENSEN e LOEGREID (2001) sustentam que a maciça introdução do "contratualismo" calcado na accountability, em parceria com a imposição de disciplina pela grande redução de staff e pelas mudanças na forma de contratação normal no setor público criaram, em princípio, um serviço público mais responsável e cumpridor de ordens. Entretanto, parece também que estaria surgindo uma nova cultura carreirista, caracterizada pela busca oportunista de recompensas pecuniárias - "se não está especificado, não é responsabilidade minha" - aumentando o "risco moral" que a economia das organizações busca evitar. Esta constatação apenas reforça a tese de que a efetividade da ação da burocracia depende de um ethos de serviço público baseado na idéia de confiança e solidariedade. A ética utilitarista dos liberais não seria suficiente por si só para resolver o problema moral do Estado. Em nome da busca da eficiência, haveria a possibilidade de se subverter o caráter específico de organizações imersas em uma cultura onde vigoram os laços pessoais e a cooperação voluntária, em contraponto à impessoalidade de mercados e burocracias (GOODIN 2000).

A natureza intensiva do trabalho em serviços de saúde, sua extrema dependência do trabalho profissional e as dificuldades decorrentes para a adoção de alternativas tecnológicas poupadoras de força de trabalho no setor vinculam, de forma inexorável, as possibilidades de sucesso das 
reformas setoriais, que visem aumentar a eficiência, a resolutividade, a equidade e o acesso aos serviços de saúde, à capacidade de regulação da gestão das relações profissionais e das relações de trabalho em saúde.

No caso específico do setor público de saúde, PIERANTONI (2001) aponta que seria desejável que a formulação de políticas setoriais absorvesse e praticasse, também no setor público, alguns princípios básicos utilizados na administração empresarial (referencial tão caro à reforma de Estado), que se relacionam à valorização profissional por um lado, e à adoção de práticas regulatórias da autonomia e do corporativismo de outro.

De fato, VAITSMAN (2001) analisando a cultura e expectativa entre servidores públicos de saúde conclui que "a incongruência entre o discurso e as práticas oficiais, produz frustração em relação aos projetos pessoais e profissionais, levando à desmotivação e dificultando a formação de expectativas positivas em relação às possibilidades de mudança."

\subsection{O CONCEITO DE EFICIÊNCIA NA REFORMA DO ESTADO}

A reforma constitucional que alterou o artigo 37 da Constituição Federal de 1988, tornando-se conhecida como reforma administrativa, eleva a eficiência a princípio constitucional, ao lado dos princípios de legalidade, impessoalidade, moralidade e publicidade. Para NOGUEIRA (1999) por mais que se possa defender o aumento da eficiência na prestação de serviços públicos, ela em si não poderia ser interpretada como um princípio de ação de estado, em pé de igualdade com os outros. Para este autor os outros preceitos dizem respeito à dimensão da justiça e da ética - sendo 
definidores de uma condição de Estado de Direito. Tais princípios seriam, ao mesmo tempo, qualidades de um Estado legal e justo, e, como tal não podem ser concebidos a partir da noção quantitativa. Nenhum estado poderia ser mais ou menos legal, mais ou menos moral. Já o conceito de eficiência, pelo contrário, tendo raiz econômica, é essencialmente quantitativo, e o que pretende a reforma do Estado é justamente fazer com que os niveis de eficiência aumentem a prestação de serviços públicos. "Neste caso, mais uma vez, a determinação de ordem econômica é sobrestimada e posta num lugar que não the é próprio" (NOGUEIRA 1999:70).

Por sua vez MODESTO (2000) contrapõe argumentando que o termo eficiência não seria privativo de nenhuma ciência, sendo um termo natural, apropriado pelo legislador em sua acepção comum ou com seu sentido técnico próprio. Portanto, não se poderia recusar a positividade, a operatividade e a validade jurídica do principio da eficiência sob o argumento de que seu conceito foi tradicionalmente desenvolvido pela sociologia e pelas ciências econômicas. $O$ autor rebate a afirmação de que o principio da eficiência teria ingressado na ordem constitucional brasileira, como principio geral da administração pública com a Emenda Constitucional nº19 de 1998, que a introduziu expressamente no caput do art. 37 . Pois, a boa gestão da coisa pública é obrigação inerente a qualquer exercício da função administrativa e deve ser buscada nos limites estabelecidos por lei. A função administrativa é uma função finalista, exercida em nome e em favor de 
terceiros, razão pela qual exigiria legalidade, impessoalidade, moralidade, responsabilidade, publicidade e eficiência dos seus exercentes.

Afirmando que o principio da eficiência ressente-se ainda de uma limitação de seu conteúdo prescritivo MODESTO (2000:116) propõe um conceito do principio da eficiência como: "a exigência jurídica, imposta à administração pública e àqueles que thes fazem às vezes ou simplesmente recebem recursos públicos vinculados de subvenção ou fomento, de atuação idônea, econômica e satisfatória na realização das finalidades públicas que the forem confiadas por lei ou por ato ou contrato de direito público." Conceituação esta muito próxima às diversas citações encontradas nos textos do MARE.

O conceito de eficiência nos documentos elaborados pelo MARE, apesar de manter a sua concepção original não encerra o mesmo sentido e conteúdo econômico com que se empregava anos atrás. Recobre-se, sem dúvida, de atributos qualitativos: o que funciona bem, o resultado que soluciona satisfatoriamente um problema, em direção ao bom. Esta acepção estaria, segundo SUÁREZ (2000), em completa correspondência com as mudanças no significado das palavras como conseqüência de processos objetivos de evolução social, que no caso do idioma, por suas peculiaridades, obedece a leis diferentes das que regem o processo de interação dialética de toda formação socioeconômica. Este processo não pode ser arbitrário, muito menos em um mundo fortemente interconectado por avanços técnicoscientíficos no campo das comunicações, de tal sorte que a partir de um limite se impeça a introdução de acepções modificadas ou bastante distantes das que oferece o dicionário. 
A utilização da palavra eficiência na literatura de viés gerencialista representaria uma prática discursiva de "pressuposição". Segundo FAIRCLOUG (2000) apud MISOCZKY (2001), todos os textos têm uma mistura de significados explícitos e implícitos do que é dito e o que é pressuposto ou tomado como dado. No entanto, em alguns casos as pressuposições são tomadas como boas em si mesmas e devem ser buscadas em qualquer situação. Foi o que ocorreu com o conceito de eficiência nas reforma do Estado (não somente na brasileira). Nessas pressuposições estaria implícito que as práticas gerenciais de mercado são superiores e mais conseqüentes que as das organizações públicas, pois as organizações privadas conseguem sobreviver e expandir-se em ambientes competitivos. POLLIT (1990) indica como a retórica da eficiência é fator central na legitimação da neutralidade e capacidade técnica dos administradores profissionais, além de ter a função de mascarar o caráter ideológico da abordagem gerencialista. A idéia de uma gestão mais eficiente é utilizada como arma de retórica para ocultar seus princípios conservadores sob a suposta neutralidade técnica dos administradores profissionais. $O$ que caracterizaria o eficientismo (gerencialista) como uma doutrina ou ideologia administrativa, nesse sentido, é o fato do seu enorme sucesso nos últimos anos não estar ligado necessariamente à comprovação empírica dos seus pressupostos, mas à capacidade de obter aceitação através de instrumentos de retórica (BORGES 2000).

A "Nova Administração Pública, e sua eficiência, segundo ANDREWS e KOUZMIN (1998) seria vendida como um instrumento técnico, 
descompromissado com o espectro político e tendo como objetivo servir aos interesses dos "clientes do Estado", consistindo, portanto, numa gramática deslocada do contexto real, disfarçando, assim, seu racionalismo econômico. Como observou HABERMAS (1996), o papel da ideologia é evitar o discurso prático, isto é o contexto comunicativo no qual as normas e instituições são legitimadas.

A pressão determinista de que a "nova administração pública" é a única reforma apropriada, capaz de aumentar a legitimidade do sistema políticoadministrativo, neste ambiente de incerteza, teria criado um predominio ideológico tornando-a um "mito institucionalizado", nos termos definidos por MEYER e ROWAN (1999). Em outras palavras, uma vez que algo tenha alcançado o status institucional, ele se torna tão aceitável na sociedade, gozando de uma caracteristica de perpetuidade que não requer ações evidentes para a continuidade de sua existência (SCOTT 1987) ${ }^{30}$. Estruturas, processos e papéis tornam-se rotinizados, formalizados e embebidos na constituição organizacional e na sua manutenção "em longos períodos de tempo sem outras justificações ou elaborações, e são altamente resistentes à mudança" (ZUCKER 1987:446).

Há poucas provas de que a aplicação das estratégias de reforma baseadas no modelo da "nova administração pública" produzem realmente os resultados desejados. Os efeitos e conseqüências do modelo da administração gerencial são dados por pressuposição, porém não documentados. CHRISTENSEN e

${ }^{30}$ SCOTT (1987) diz que a institucionalização é “(...) vista como um processo social pelo
qual indivíduos aceitam dividir definições da realidade social - a concepção validadora é 
LOEGREID (2001) utilizando como base empirica os exemplos da Noruega, Nova Zelândia e Austrália discutem os efeitos da nova administração pública. É interessante observar o título da conclusão do trabalho: "menor controle político e pior governo?" Segundo os autores as reformas têm gerado mais ceticismo sobre as soluçōes coletivas, a despolitização do setor público e mais conflitos sobre o que é público. O estudo de FERLIE et. al (1999) sobre a experiência de para-mercados do sistema de saúde inglês, indicam que não se demonstraram os resultados esperados, ou seja, as oportunidades de escolha dos pacientes não aumentaram ou se qualificaram. A não ser, talvez, para cerca de $12 \%$ do público britânico que passou a comprar planos suplementares de saúde, no final da era Thatcher (DIXON e ROBINSON 2002).

Pior, como têm defendido ao longo das últimas décadas diversos autores, o foco predominante no aumento da eficiência dos processos administrativos pode lesar políticas que supostamente deveriam apoiar. Direitos substantivos, equidade, proteção de direito das minorias, bem como a igualdade entre os cidadãos são valores que devem ter precedência com relação à eficiência (MISOCZKY 2001).

Para COHN (1999) a implementação da racionalidade própria do setor privado na gestão do setor público estatal, faz com que este atue sob a mesma lógica de custo/efetividade. Eficiência - produzir mais com menor custo - traduz-se em efetividade - produzir com menor custo gerando maior impacto, comprometeria a essência da responsabilidade do estado, que consiste em implementar politicas sociais redistributivas. A primazia da 
urgência econômica sobre a social estaria agravando o traço histórico das politicas sociais brasileiras reprodutoras das desigualdades sociais. $\mathrm{O}$ discurso (da eficiência) não é um simples espelho da "realidade", mas traz embutido situações, objetos de conhecimento e identidades sociais, relações entre pessoas e grupos de pessoas. Assim, as práticas discursivas podem ter um grande efeito ideológico: elas podem produzir ou ajudar a produzir relações iníquas (entre pessoas, classes e grupos sociais).

Diversos trade-offs entre eficiência, efetividade e equidade são identificáveis na análise mais detalhada da agenda reformadora, evidenciando, entretanto, várias contradições: entre 0 aumento de eficiência e a diminuição da equidade na perspectiva das reformas orientadas para o mercado; entre o aumento da eficiência e a diminuição do acesso, com as medidas de contenção de custos, com possivel aumento das desigualdades, nos modelos de separação entre financiamento e provisão e competição administrada.

Segundo o Plano Diretor da Reforma do Estado a eficiência seria alcançada a partir do resgate da agilidade de gestão, da qualidade da prestação de serviços numa administração descentralizada - sob controle direto dos usuários - que atenderia as demandas deste cidadão/cliente. A eficiência é alçada a conceito chave para alcançar-se a governança, vista como a capacidade do Estado em implementar as politicas decididas.

Parafraseando BAUMAN (1999:7) a "eficiência", como a globalização, está na ordem do dia; uma palavra da moda que se transforma rapidamente em lema, 
uma encantação mágica, uma senha capaz de abrir as portas de todos os mistérios. Para algumas organizações, "eficiência" é o que deve ser feito para sobreviver; para outras, pode ser perder sua razão de ser.

\subsection{HOSPITAL DAS CLÍNICAS DA UFMG: MUDANÇAS ORGANIZACIONAIS E GERENCIAIS PARA A EFICIÊNCIA}

As organizações de saúde vêem experimentando pressões para aumentarem a eficiência e efetividade. A força ambiental primária dirigida às mudanças nos hospitais ocorreu nos métodos de financiamento e remuneração das ações de saúde e na introdução de novos agentes de regulação (ROGGENKAMP 2001). Com a criação do SUS, a forma de pagamento prospectivo, denominada Autorização de Internação Hospitalar (AlH) é disseminada, para os prestadores de serviços hospitalares ao SUS, públicos e privados. Dentre os hospitais públicos, os universitários federais sofrem um impacto adicional: observa-se um panorama de desobrigação progressiva do MEC com estes hospitais.

Por sua vez, as "turbulências" crescem no ambiente externo. Acentua-se o processo de reforma de Estado e setorial dentro de uma crise fiscal e mudança de paradigma na nova ordem mundial. O HC procura responder a esse ambiente de incertezas. Observamos, em todas as categorias analisadas, que o $\mathrm{HC}$ vem progressivamente abrindo-se e adaptando-se às conjunturas do ambiente externo. No I Seminário as discussões estavam voltadas para o próprio HC: reestruturação de seu modelo organizacional, assistencial e pedagógico respondendo mais a uma necessidade interna 
(por ausência ou colapso de modelo anterior) do que para adequar-se às mudanças no ambiente externo. Tinha-se uma expectativa de manutenção de financiamento baseado no orçamento, apesar da venda de serviços ao SUS ser uma realidade. Cada Plano Diretor, entre 1992 e 1998, é uma tentativa de implementar as reestruturações internas e ao mesmo tempo apresentam propostas emergenciais - de sobrevivência - para manter o hospital funcionando. O III Seminário, já ocorre dentro do processo de consolidação das reformas do Estado e setorial. Neste contexto, as mudanças propostas parecem ser ditadas pela necessidade de adaptar-se e ter legitimidade neste novo ambiente. Esta reestruturação visa proporcionar ao $\mathrm{HC}$ maior agilidade e flexibilidade operacional, para atender as demandas dos novos financiadores/compradores: os governos municipal e estadual e os planos e convênios privados de saúde. No entanto, são colocados, em todos os documentos analisados, como valores inarredáveis a indissociabilidade entre ensino, pesquisa e assistência e que uma assistência de qualidade é geradora de ensino de qualidade.

Segundo COSTA et. al (2000) na busca de sobrevivência as instituições públicas de saúde têm realizado mudanças organizacionais, procurado novas fontes de financiamento e parcerias institucionais. No entanto, essas mudanças têm ocorrido de modo fragmentado, localizado e experimental. Ocorreria uma espécie de "reforma silenciosa e não explicita", configurandose um processo de socialização de normas e redesenho de valores sobre as funções do Estado ou o papel das organizações públicas. A experiência de 
adaptação vivenciada pelo $\mathrm{HC}$, na década de 90 , poderia ser um exemplo desta "reforma silenciosa".

Segundo a teoria institucional as organizaçōes são "estruturadas pelo fenômeno em seus ambientes e tendem a tornarem-se isomórficas com ele" (MEYER e ROWAN 1999). Tendências isomórficas levam organizações a adotar produtos, serviços, técnicas, políticas e programas que podem não resultar em aumento da eficiência ou melhoria da performance. Entretanto, estes elementos são tomados por "verdadeiros" como necessários e apropriados - eles legitimam a organização do ponto de vista interno e externo. POWELL e DiMAGGIO (1999) identificam três formas nas quais ocorrem processos e mudanças institucionais isomórficas: Isomorfismo coercitivo está relacionado às pressões formais e informais exercidas por outras organizações das quais ela é dependente e através de expectativas culturais na sociedade dentro da qual esta organização trabalha; Isomorfismo normativo refere-se a socialização imposta por jogadores chave (especialmente as profissiões) no ambiente técnico que influenciam a organização para adotar estruturas e processo que são consistentes com as normas, valores e padrōes comungados pelas profissões. Finalmente, isomorfismo mimético resulta quando organizações modelam-se como cópias de outras organizações em respostas à incerteza, tecnologia pouca compreendida e metas ambíguas. Em outras palavras, o isomorfismo é uma força poderosa influenciando as estratégias de tomada de decisão. As organizações provedoras de saúde também apresentam tendências isomórficas. As organizações aprendem umas com as outras através da 
participação em associações comerciais, conferencias, seminários e várias formas de redes de trabalho mesmo havendo competição entre elas por gerência, (staff) médicos especialistas, recursos, prestígio e favores público. Elas procuram validação externa através de processos de acreditação, participação no desenvolvimento de políticas e pesquisa, campanhas de caridade e outros serviços comunitários (POWELL e DiMAGGIO 1999; HANLON 2001).

No entanto, é necessário notar que não se trata de fazer do hospital um lugar de repercussão mecânica das orientações político-ideológicas dominantes, na mesma medida em que não é possivel atribuir-lhe uma autonomia total. Retém e usa, segundo uma lógica organizacional que the é específica, um sistema próprio de normas e valores, embora decalcado do modelo geral das normas e valores sociais. Adapta-se às mudanças no ambiente, mas conserva uma importante margem de definição e tomada de decisão que correspondem a processos específicos de produção e reprodução das relações de poder dentro do hospital (CARAPINHEIRO 1998).

As realidades de gestão dos hospitais públicos no limiar dos noventa, na sua maioria eram marcadas pela improvisação, pelas ações voltadas para emergências, pela grande centralização e baixa autonomia dos dirigentes locais, pela ausência quase completa de compromisso com os resultados, pela irracionalidade e desperdício de recursos (BARBOSA 1996). A descentralização proposta no Seminário de 92 foi, com a criação das Unidades Operacionais, a uma primeira tentativa de imprimir uma 
racionalidade gerencial, frente ao "caos" gerencial no HC. Podemos dizer que se tratava mais de uma desconcentração das atividades, pois o processo de decisão, a gestão dos recursos humana e financeira ainda era bastante centralizada, ademais de que o processo de pactuação de metas e controle de resultados era um acordo entre a diretoria e a Unidade Operacional. O organograma ainda era bastante piramidal, com as UO mantendo a mesma estrutura fragmentada de unidades assistenciais e administrativas. Na prática o processo de descentralização não avançou além da Unidade Operacional piloto, experiência esta bem avaliada, posteriormente, nos Planos Diretores de 1994 e 1995.

O projeto de descentralização proposto no Seminário de 1998 não somente parte de um ambiente interno que já vinha utilizando alguns instrumentos gerenciais, por exemplo, a análise de custos como incorpora algumas das proposições e elementos do discurso da reforma administrativa como o contrato de gestão, avaliações de desempenho, criação do Conselho de Usuários do $\mathrm{HC}$ e a necessidade de uma gerência eficiente. As Unidades Funcionais são constituidas por um conjunto de recursos humanos, materiais e área física agrupados por identidade quanto à sua atividade principal. As unidades passam a ser as células administrativas do hospital, dotadas de autonomia para gestão de recursos e gerenciamento de processos, com estrutura multidisciplinar. O contrato de gestão é o mecanismo pela qual se estabelece a pactuação de metas de trabalho (e respectivos indicadores), obrigações, responsabilidades, recursos, mecanismos de avaliação e penalidades estabelecidas de comum acordo 
entre a unidade funcional e a diretoria. O organograma, apesar de atender às pressões corporativas é mais horizontalizado, diminuindo bastante os niveis hierárquicos. Esta proposta está em consonância com o modelo adotado (e considerado um sucesso) por alguns hospitais públicos, como 0 Serviço de Saúde Candido Ferreira (Campinas) e o Centro Geral de Reabilitação da Fundação Hospitalar de Minas Gerais (Belo Horizonte) CECÍLIO (1997).

Utilizando a perspectiva neo-institucionalista de POWELL e DiMAGGIO 1999), podemos dizer que o HC mimetiza um exemplo bem sucedido de organização gerencial, 0 que the garantiria legitimidade frente aos financiadores/compradores e a sociedade. Aumenta, assim, a sua probabilidade de sobrevivência/sucesso face a um ambiente de incertezas.

Além disso, COSTA et. al (2000) chamam atenção que o processo de reforma do setor saúde no Brasil transcorre por mecanismos de difusão de novos padrões e práticas administrativas na comunidade técnica dos gestores de organização pública. Isto, talvez, explique porque as mudanças organizacionais têm ocorrido de forma fragmentada, localizada e experimental.

Se no início dos noventa, ainda se tinha expectativa de que o governo federal continuaria a investir nos hospitais públicos, em especial aqueles sob sua esfera de controle, os últimos anos do milênio desfizeram-na. A forma de financiamento do $\mathrm{HC}$ parece confirmar que as pressões sofridas pelos hospitais públicos e, em particular os universitários, os levaram a procurar fontes alternativas de financiamento, num ambiente onde os recursos 
oriundos diretamente do orçamento governamental são cada vez mais escassos. Um dos pilares da proposta da reforma do Estado brasileiro na década de 90 assenta-se na separação entre financiamento e provisão dos serviços. O núcleo da mudança é a perda do repasse automático de recurso orçamentário público por série histórica ou reembolso da conta apresentada (pagamento retrospectivo pelo custo) e sua substituição pelo repasse, quase que exclusivamente, devido à remuneração da produção de serviços prestados ao SUS (ALMEIDA 1999; LEVCOVITZ et. al 2001). Um dos fatos mais marcantes do setor saúde brasileiro é a presença do Estado como um jogador institucional chave. A compra de serviço pelo SUS pode representar até $100 \%$ da renda de hospitais públicos e mesmo filantrópicos (GIRARDI et. al 2001; MALIK e TELES 2001). No caso do Hospital das Clínicas/UFMG, a venda de serviços ao SUS representou entre $83 \%$ a $92 \%$ da arrecadação oriunda da prestação de serviços. Deve-se ressaltar ainda que a forma de pagamento para serviços de saúde utilizada pelo SUS é, desde a década de 80 , baseada na produção por "paciente tratado" no nível hospitalar e por procedimento realizado no ambulatório. Colocou-se um preço em tudo o que os hospitais públicos fazem, portanto, não fazer o que não seja pago pode ser contraditório com os valores e princípios da res publica no setor saúde. Existem muitos aspectos do cuidado à saúde que podem ser valorados, mas não precificados. Segundo DUCKETT (1995) a ênfase na mensuração e precificação de produtos não ocorre somente no cuidado hospitalar, mas é uma característica contemporânea das estratégias de mudanças do setor público de muitos países. Para este autor, tal estratégia basear-se-ia numa 
ingênua concepção econômica na qual assume-se que a eficiência econômica é o único valor político relevante e que a busca por eficiência (acima de outros valores como a equidade ou o desejo de promover o comportamento altruistico) é um valor neutro. Esta concepção é cada vez mais questionada em parte porque a simples busca da eficiência e a negligencia com o altruísmo e outros comportamentos morais são uma estratégia com conseqüências negativas imprevisiveis (DUCKETT 1995).

A restrição de recurso orçamentário e a extrema dependência de um "comprador único" levaram o HC a buscar novas fontes de financiamento que o permitissem continuar a prover serviços. Assim, em 1995 o HC/UFMG, "imitando" outros hospitais públicos e universitários, abre as portas à clientela de planos e seguros privados de saúde ${ }^{31}$. Esta observação estaria de acordo com a teoria neo-institucional que prediz que quanto maior é a centralização de oferta de recursos da organização, maior seria o grau com que esta organização mudaria isomorficamente a fim de parecer-se com as organizações que dependem deste mesmo recurso - isomorfismo coercitivo (DiMAGGIO e POWELL 1999).

O quadro mais geral do progressivo descompromisso financeiro do governo federal (MEC) com os hospitais universitários e o processo de municipalização, perpassados pelas propostas de reforma do Estado, foram fatores fundamentais para a realização de convênios, com transferência de

\footnotetext{
${ }^{31}$ Em 21 de junho de 1995, o Conselho Administrativo aprovou o convenio com a Cooperativa Médica de Belo Horizonte (UNIMED), garantida a observância da determinação de utilização de $30 \%$ dos leitos hospitalares disponiveis no hospital. Deve-se ressaltar que o HC sempre foi aberto à clientela de desembolso direto (particular), apesar de não representar uma politica de complementação de financiamento.
} 
recursos, entre o $\mathrm{HC}$ e órgãos públicos de saúde. Se por um lado estes convênios representam maior integração, hierarquização e até mesmo, capacidade de regulação dos diferentes níveis governamentais da gestão da saúde, por outro mostram que o repasse de recursos públicos estaria vinculado à definição do pacote de serviços "necessários" a ser comprados cuja remuneração permanece sendo por produção (ALMEIDA 1999; CAMPOS et. al 1998). As organizações que dependem da mesma fonte de recursos (financiamento, pessoal, e legitimidade) estão mais sujeitas aos desejos dos provedores do recurso do que as organizações que podem contrapor uma fonte à outra. Nos casos em que não estão disponiveis fontes alternativas, ou se requer esforço de localizá-las (maior custo de transação) o financiador/comprador pode obrigar ao provedor a adotar suas práticas e/ou ajustar-se às sua necessidade (POWELL e DiMAGGIO 1999)

Nas relações de trabalho, o diagnóstico é comum em ambos os Seminários e nos Planos Diretores do HC - corporativismo, jornada de 30 horas, condições de trabalho, salário e diferenças nos vinculos de contratação, mas são tratados de maneira completamente diferente. Em 1992, as discussões estão concentradas nos problemas, as soluções deveriam vir de fora (do MEC, do aumento da tabela de procedimentos do SUS). Em 1998 destacase a forte visão gerencial para tratamento dos problemas, apresentando programas, formas de abordar o problema, soluções, etc. A gestão de recursos humanos é extremamente valorizada como viabilizadora das mudanças necessárias. No entanto, talvez as relações de trabalho ainda sejam um dos nós górdios, a ser enfrentado pelo $\mathrm{HC}$, a exemplo das 
organizações públicas de saúde. Os recursos humanos do HC estão inseridos numa multiplicidade de vínculos e formas de contratação. Assim, temos o estatutário federal (com garantia de emprego, remuneração fixa por tempo e benefícios previdenciários), noutro extremo está o RPA, sem qualquer direito trabalhista, com remuneração variável por produção. Neste intersticio existe uma gama de outras formas, como bolsas de estudo, contrato celetista, terceirizados de empresas e cooperativas de trabalho. Além disto, a forma de atuação dentro do hospital, também é variada: há os que ensinam e prestam assistência, os que prestam assistência e ensinam, os que aprendem e prestam assistência e prestando assistência aprendem, os que prestam assistência, ensinam e aprendem.

A convivência de diversas formas de contratação num mesmo espaço de trabalho não é particularidade do HC. Nos anos noventa, na tentativa de contornar a rigidez imposta pelo RJU, os serviços públicos de saúde praticaram uma variada gama de formas de contratação/vinculação do trabalho previstas em lei, para além da tradicional terceirização externa, ou contratação de prestação de serviços de atividades de apoio e manutenção (limpeza, lavanderia, segurança etc). A venda de serviços de especialistas médicos e de outros profissionais (pessoal de enfermagem, fisioterapeutas e odontólogos etc), geralmente é realizada, preferencialmente, via contratação de sociedades ou empresas de profissionais "liberais" e cooperativas. Os contratos temporários de trabalho caracterizam-se pela diminuição dos niveis de proteção social do trabalho, por menores salários, por ausência de benefícios e, fundamentalmente, por niveis espantosamente mais altos de 
rotatividade (NOVIK 1996; GIRARDI 1998; NOGUEIRA 1999; CHERCHIGLIA 1999).

A multiplicidade de formas institucionais de contratação e vinculação é um dos aspectos das transformações no mundo do trabalho, fundamental, figurando, nos dias de hoje, no cerne da problemática da gestão dos serviços de saúde. Uma série de manifestações disfuncionais que se apresenta aos gerentes dos serviços e sistemas de saúde como a proliferação dos contratos e da burocracia para sua administração, o crescimento da concorrência e dos conflitos entre grupos, a diminuição da disposição à cooperação entre profissionais e especialidades e entre o trabalho e a gerência; as crescentes dificuldades dos diretores e gerentes de serviços em gerirem a qualidade técnica e ética do trabalho profissional dada a proliferação de núcleos atomizados de mando e decisão; a diminuição da participação e a perda do interesse dos trabalhadores na missão dos serviços de saúde; o descompromisso com a continuidade e a integralidade dos cuidados de saúde; a desumanização do atendimento aos usuários; entre outras; decorre, em larga medida, da relativa escassez de critérios e da forma desordenada como vem sendo conduzida a terceirização dos serviços de saúde. Estas situações produzem crescente insatisfação dos usuários com relação à qualidade e à resolutividade dos serviços de saúde (CHERCHGLIA 1999; GIRARDI et. al 2001).

Segundo SANTANA (1999) deve-se buscar uma modificação na relação de trabalho dentro das instituições de saúde assentada numa perspectiva negocial-coletiva e de responsabilização no trabalho. As opções eficientistas 
de flexibilização, ou seja, a busca da eficiência "a qualquer custo" retira a possibilidade do engajamento participativo dos trabalhadores, condição necessária dos esquemas de produção de qualidade. Portanto, o objetivo deve ser o estabelecimento de intensa participação dos trabalhadores na reorganização do processo de produção e a introdução de mecanismos permanentes de negociação e de intercâmbios de informação entre a administração e servidores, além da definição conjunta de sistemas de remuneração vinculados ao desempenho de grupos ou setores. A responsabilização implica efetivo comprometimento do trabalhador com a missão e os objetivos institucionais, ou seja, com as necessidades do cidadão-usuário.

É interessante observar que, de certa maneira, as propostas, apresentadas no III Seminário, e hoje em implantação no HC, já se encontravam em discussão desde o início dos anos noventa, com o I Seminário. A necessidade de uma estrutura hierárquica mais horizontalizada, em que o poder das categorias profissionais (médica e de enfermagem) fosse reduzido já encontrava eco desde aquela época. Da mesma maneira a necessidade de uma gerência descentralizada (das decisões e responsabilidades), mais profissionalizada, com autonomia gerencial, planejamento estratégico e participativo, definição de metas, baseado nos resultados e na racionalização de recursos e na lógica do compromisso com a qualidade do atendimento; transparência administrativa, também já estava colocada desde 1992, assim como os reclamos por maior eficiência. Como disse um ex-diretor: "Então não foi nem uma decisão política do hospital, não foi nada 
pensado pela universidade, pelo hospital, de ter essa mudança. Eu acho que de todo jeito isso aconteceria, porque as coisas vão ficando maduras e um dia acontece." Entretanto, algumas explicações poderiam ser aventadas. Podermos dizer que o HC como hospital universitário é uma organização duplamente profissional ou colegiada: a dos médicos e a dos professores. Segundo MINTZBERG (1995) nas organizações (burocracias) profissionais, a variável mais expressiva é que o trabalho finalístico, próprio de seu centro operacional, exige qualificações de alto nível, pouco passíveis à formalização e normatização (controle). Além disso, os serviços profissionais são, caracteristicamente, de grande procura. Isso dá mobilidade ao profissional, o que the permite ter considerável autonomia em seu trabalho. O profissional é portador de habilidades construídas independentemente da organização e os padrões de conduta e legitimação são originados fora de sua estrutura, nas associações autogovernadas. Os profissionais tendem a apresentar maior compromisso e lealdade com a sua tarefa e com a sua profissão do que com o todo organizacional. Ademais, operam com base na perícia, também fonte de poder, enfatizando a autoridade dos especialistas. Como resultado, a relutância dos profissionais em trabalharem cooperativamente se traduz no problema da inovação.

PERROW (1972) em análise das organizações complexas afirma que os grupos que, em cada momento, controlam uma organização são os que os que desempenham as tarefas mais dificeis e criticas. Considera que as tarefas difíceis são as que não podem ser rotinizadas nem atribuídas a pessoas com baixos niveis de qualificação e que as tarefas criticas são, não 
só as que representam o problema mais importante que a organização enfrenta num determinado estádio do seu desenvolvimento. Então o poder de controle de cada grupo na organização resultará da importância das tarefas críticas e dificeis que desempenha num dado momento do desenvolvimento da organização, de cuja influência resultarão a definição de políticas, a tomada de decisões e a correspondente determinação dos objetivos operacionais.

Nestas organizações, o papel da tecnoestrutura, do nível intermediário e mesmo de seu centro de decisão sobre o trabalho de seus operadores, é limitado. A alta hierarquia gerencial desempenha papéis-chave entre os profissionais e o ambiente externo - governo, associações de usuários, financiadores/compradores, etc. Espera-se que os administradores protejam a autonomia dos profissionais das pressões, ao mesmo tempo em que tenham capacidade de manter contatos e negociar com os órgãos de fora.

Portanto, na burocracia profissional, com a autonomia dos operadores, as formas colegiadas das decisões e a relutância em trabalharem cooperativamente, o poder para a mudança estratégica torna-se difuso. Todo o mundo, e não somente os gerentes ou representantes profissionais devem concordar com a mudança. Com isso, esta vem devagar e dolorosamente, e só depois de muita intriga política e manobras astutas por parte dos profissionais e administradores empreendedores (MINTZBERG 1995:209). As longas, dificeis, debatidas e consensuadas decisões tomadas pelo Conselho Administrativo do $\mathrm{HC}$ espelham bem esta assertiva de MINTZBERG (1995). Além disso, algumas categorias profissionais - 
médicos e professores - e instâncias institucionais - reitoria, direção da Faculdade de Medicina, departamentos etc - têm oportunidade e poder de veto sobre as decisões, o que transforma o processo decisório em uma negociação permanente sobre "as regras do jogo" (IMMERGUT 1996).

Uma outra hipótese, ainda no ambiente micro-organizacional, seria a postulada por COSTA et. al (2000) de que as organizações hospitalares, complexas e com monopólio de competência, tenderam a acumular elevada "folga organizacional" ao longo de sua formação. Ou seja, pela ausência de constrangimentos externos ou incentivos internos, a maioria das organizaçōes pôde operar abaixo de sua capacidade (física e humana). Essa folga organizacional expressaria, em condições previsiveis e de normalidade, ineficiência e baixo empenho na geração de beneficios públicos. Parece que o $\mathrm{HC}$ veio mobilizando as possíveis reservas adquiridas nos tempos de bonança financeira o que permitiu um processo paulatino de mudanças para enfrentar as situações de incerteza em seu entorno (especialmente no comportamento da política pública). Entretanto, quando pressões regulativas, normativas e cognitivas são suficientemente fortes no ambiente organizacional (interno ou externo), a necessidade por reconhecimento social e aceitação vence o peso da imutabilidade da organização (SCOTT 1987). Mudanças ocorrem resultando em novas estruturas ou processos que podem se tornar institucionalizados dentro da organização, ao longo do tempo. A teoria institucional sublinha que a mudança organizacional procura a construção de legitimidade. $E$ a legitimidade pode ser obtida ou assegurada, pela organização, ao adotar 
estruturas e processos prevalentes em todo o campo das organizações através do processo de isomorfismo (DEEPHOUSE 1996; SUCHAMN 1995).

\subsection{EFICIÊNCIA E PRODUÇÃO DE SERVIÇOS}

A duplicação da arrecadação do Hospital das Clínicas longe de parecer ser uma política de investimento por parte do Estado tende a confirmar as pressões sofridas pelos hospitais públicos, e em particular os universitários, a procurarem fontes alternativas de financiamento, num ambiente onde os recursos oriundos diretamente do orçamento governamental foram cada vez mais escassos. Assim, a venda de serviços ao SUS e aos planos privados de saúde e particulares passou a constituir a principal fonte de recursos para a manutenção das atividades do HC. O governo federal (MEC), cobre, somente, $61 \%$ da folha de funcionários do $\mathrm{HC}$ e, pontualmente, financia a aquisição de novos equipamentos como o atual projeto de desenvolvimento de infra-estrutura dos Hospitais Universitários, com o objetivo de consolidalos como centros de excelência no ensino e pesquisa, e fortalecendo-os como instituições de referência para o SUS (www.mec.gov.br/Sesu/moderniz.shtm).

Podemos dizer que o Hospital das Clínicas vem se tornando, a exemplo de outros hospitais de ensino, importante parceiro dos gestores do Sistema Único de Saúde, pois vem aumentando sua participação no volume de internações realizadas pelo SUS. Em estudos realizados no Estado do Rio de Janeiro, como em Belo Horizonte, foram reportados crescimentos da ordem de $54 \%$ e $300 \%$ respectivamente, entre 1992 e 1996 (GOUVEA et. al 
1997; JORGE et. al 1998). A hipótese mais geral é que, neste período, houve migração de leitos e hospitais privados para o regime universitário, provavelmente devido à instituição do Fator de Incentivo ao Desenvolvimento do Ensino e Pesquisa (FIDEPS), responsável pelo acréscimo de um percentual que variava de $25 \%$ a $75 \%$ na fatura paga pelo SUS. Além disto, com o processo de descentralização vários gestores municipais cumprindo seu papel de regulador, controlador e avaliador das ações e serviços de saúde em seu âmbito de atuação, muitas vezes cumprindo os ditames constitucionais, procuraram priorizar os hospitais públicos, e os universitários, como parceiros privilegiados na prestação de serviços ao SUS. Neste aspecto destaca-se a criação do Pronto Atendimento do HC financiado com recursos do Fundo Municipal de Saúde (CAMPOS et. al 1998; JORGE et. al 1998). Podemos inferir, também, que o aumento de produção pode estar relacionado, ainda que indiretamente, a um aumento de registros. Estudos sobre a utilização de formas de pagamentos prospectivos baseados no diagnóstico, como a $\mathrm{AlH}$, têm demonstrado que após os primeiros anos os médicos aprendem (e são incentivados pelos hospitais) a codificarem mais apuradamente os diagnósticos. Como disse um entrevistado;

“(...) Várias pessoas que chegam lá, que não conhecem o faturamento, pensam que o faturar é só você conhecer letra de médico. Não é bem isso. Você tem que saber deduzir coisas, extrair informações daquele prontuário para você chegar a um cálculo, transformar aquilo ali em matemática. Então, realmente foi um investimento muito grande e eu acho que, em relação a isso, a diretoria do hospital está de parabéns pelo investimento que foi feito (...)" (Entrevista) 
Um outro ponto, talvez o mais importante para os hospitais públicos e universitários, foi seguir a "regra do jogo", ou seja, aumentar a produção para continuar sobrevivendo. Esta hipótese, também foi aventada por DUCKETT (1995), quando avaliou a introdução de mecanismo semelhante ao da AlH na Austrália, para explicar o aumento de internaçōes nos hospitais universitários australianos.

Não é surpreendente o crescimento da produção, em particular a hospitalar do HC entre 1994 e 2000. Observamos que o crescimento da produção hospitalar é muito mais significativo no número de procedimentos produzidos do que no seu valor. O número de internações realizadas cresce $49 \%$ e o seu valor, no entanto, vai aumentar, somente, cerca de $15 \%$. Já o crescimento do valor da produção ambulatorial (33\%) reflete o seu incremento numérico (28\%). Portanto, os esforços para incrementar a produção hospitalar e ambulatorial parecem não ter correspondência proporcional no crescimento do valor recebido. Poderíamos dizer que este fato deve-se à não correção linear da tabela de pagamento de procedimentos hospitalar e ambulatorial que não acompanhou a inflação interna e nem a desvalorização cambial. Uma outra explicação residiria no fato de que o HC passou a executar procedimentos ambulatoriais e internações de baixo valor ou os que foram menos reajustados no periodo, ou a realizar menos os mais valorados. Esta observação pode ser evidenciada pela mudança do mix de procedimentos realizados pelo HC desde a implantação do pronto atendimento em urgência e emergência clínica, em 1996. Os procedimentos de "Diagnóstico e/ou primeiro 
atendimento em clínica médica, pediatria e clínica cirúrgica", vão se tornar os mais freqüentes, chegando a representar, em $1999,21,15 \%$ de todos os procedimentos hospitalares realizados no HC. Da mesma forma, no atendimento ambulatorial vão se destacar os atendimentos de urgência e emergência que aumentam mais de dez vezes entre 1996 e 2000. Estes procedimentos têm baixo valor na tabela do Sistema de Informação Hospitalar (SIH) e Sistema de Informação Ambulatorial (SIA). A criação do Pronto Atendimento poderia representar por um lado, um aumento da produção e indicar maior abertura do HC para a comunidade e por outro aumento de custos, pois é um serviço reconhecidamente não rentável, devido aos seus altos custos fixos (disponibilidade 24 horas de recursos humanos, equipamentos, etc) (POTTER 2000). Além disto, os procedimentos de maior valor na tabela do $\mathrm{SIH}$, como os transplantes são tecnicamente complexos e sua indicação extremamente regulada. Estes procedimentos apesar de representarem $28 \%$ do valor total das AlH pagas ao Hospital representam menos de $1 \%$ dos procedimentos hospitalares realizados. No caso dos transplantes, que requerem equipamentos especiais e profissionais capacitados, poderia ocorrer uma posição de "quase monopólio" para os hospitais universitários nestes procedimentos (MIKKOLA et. al 2001).

Um dado que chama atenção no $\mathrm{HC}$ é o aumento pouco significativo da produção ambulatorial (27\%) entre 1994 e 2000, principalmente se levarmos em conta que a hospitalar cresceu $49 \%$ no mesmo periodo. Este fato parece colocar o HC na contramão das mudanças ocorridas no setor saúde neste 
final de milênio. O processo de crescimento da participação do setor ambulatorial na economia hospitalar parece ser um fenômeno atual, decorrente das mudanças na forma de financiamento à saúde - utilizando-se até mesmo incentivos financeiros para ambulatorização - das inovações tecnológicas, da maior aceitação por parte do paciente e do maior controle dos custos pelos compradores/financiadores dos serviços (MILLER et. al 1995; CHERCHIGLIA et. al 1998; POTTER 2000; MIKKOLA et. al 2001; McKEE e HEALY 2002). Para DUFF e FARLEY (1995), um aspecto interessante destas mudanças é que o financiamento tem um impacto relativamente mais forte, nos hospitais, que as mudanças de tecnologia. Muitos dos procedimentos que atualmente estão sendo "ambulatorizados" poderiam já estar sendo realizados desde o início da década de 70 , mas os incentivos financeiros foram essenciais para que isto ocorresse.

Podemos dizer que entre os anos estudados o HC "abriu-se" para o SUS de Belo Horizonte, dobrando sua participação no número e valor pago de AlH no município. Devemos ressaltar que o aumento da participação do Hospital das Clínicas no "mercado SUS" de prestação de serviços de internação, em Belo Horizonte, ocorreu num ambiente de racionalização, com redução em cerca de $20 \%$ no número e no valor das $\mathrm{AlH}$. A queda do número de internações (AlH) ocorreu em todo país devido à nova legislação do Ministério da Saúde que estabelecia que o limite máximo de $\mathrm{AlH}$, distribuido anualmente para cada Estado, deveria obedecer ao parâmetro de cobertura em $9 \%$ da população. Em 1995, o Ministério da Saúde introduziu nova critica no SIH-SUS, na tentativa de aprimorar o sistema de informação e restringir 
as fraudes (GOUVÊA et. al 1997; JORGE et. al 1998). Fator importante na redução do número de internações em Belo Horizonte foi a intervenção efetiva do Controle e Avaliação da SMS/BH, através dos supervisores nos hospitais da cidade (JORGE et. al 1998).

Se a participação do $\mathrm{HC}$ no total dos procedimentos ambulatorial não é expressiva, chama atenção seu crescimento no total de atendimentos de urgência/emergência realizados em BH (aumento de quase cinco vezes entre 1996 e 2000), acompanhando o crescimento verificado em Belo Horizonte (cerca de três vezes). A razão deste incremento seria devida à mudança do perfil epidemiológico da população belorizontina, com o crescimento das denominadas Causas Externas (violência, acidentes etc) e, dentro do HC, à criação do Pronto Atendimento. Comportamento diferente acontece com os procedimentos de alto custo/complexidade com queda da participação do $\mathrm{HC}$ na sua realização, especialmente nos dois últimos anos analisados, caindo de $3,3 \%$ para $0,3 \%$. Esta queda ocorre no momento em que cresce, expressivamente, o número de procedimentos de alto custo/complexidade (mais de dez vezes), em BH. Algumas hipóteses podem ser levantadas para explicar o aumento do número de procedimentos de alto custo/complexidade realizados pelo SUS/BH. Primeiramente, com a criação do Sistema de Informação de Procedimentos de Alto Custo/Complexidade (APAC), antigos procedimentos foram incorporados à nova tabela e passaram a ser designados como de alto custo/complexidade. Este novo sistema de informação permite maior controle, dos gastos, cada vez maior, com estes procedimentos, pelo gestor. No entanto, poderia estar 
acontecendo um controle mais "frouxo" na SMS/BH na autorização destes procedimentos ou, até mesmo, um redirecionamento das prioridades da atenção à saúde. Outro ponto seria o processo de inovação e incorporação tecnológica no setor saúde que acarretaria aumento da demanda por essas novas tecnologias (CAMPOS e ALBUQUERQUE 1998). Uma explicação para a queda acentuada da realização dos procedimentos de alto custo/complexidade no $\mathrm{HC}$ seria que estes procedimentos são considerados os mais "rentáveis" da tabela do SUS, tornando-se alvo de acirrada competição pelos prestadores (públicos e privados). Assim, dependendo do maior ou menor grau de publicização ou privatização das decisões na SMS/BH maior ou menor prioridade seria dada ao prestador público. Além disto, o descompasso entre a necessidade do gestor municipal diante de diferentes ritmos do $\mathrm{HC}$, devido a uma estrutura e forma de organização gerencial (horário de atendimento pouco flexivel; demora na entrega de resultados, etc) poderia ter dificultado o aporte de uma cota maior ou manutenção destes procedimentos no hospital.

Em suma, a "abertura" do HC para o SUS de Belo Horizonte, dobrando sua participação no número e valor pago de AlH no município e alterando o seu mix de atendimento (grande número de procedimentos de urgência/emergência e os obstétricos), atendendo às demandas dos gestores do SUS, poderia ser importante estratégia na busca de reconhecimento e legitimação e, conseqüentemente, maior probabilidade de obter recursos e sobreviver (SUCHMAN 1995; MEYER e ROWAN 1999). 
É ínfima a participação do Hospital das Clínicas no mercado de planos e seguros de saúde, apesar do crescimento de sua importância na economia do HC. A postura pouco agressiva do HC neste mercado parece dever-se entre outras razões à cultura bastante arraigada de atendimento gratuito ao paciente "indigente" visando o ensino. Pode ser, ainda, à necessidade de cumprir o preceito constitucional de equidade do acesso e da atenção, uma vez que é um hospital público. Agrega-se a isto a forte competição neste mercado e a estrutura e organização gerencial burocrática e pouco flexível do $\mathrm{HC}$ que não conseguiria atender com presteza as demandas dos compradores privados de serviços nem ser eficiente na organização interna (melhoria dos processos de cobranças, evitar glosas às faturas etc). Segundo SUWANDONO et. al 2001 é necessário atentar para o fato que hospitais públicos ao se abrirem para o mercado privado de saúde necessitam ter uma administração e um sistema de custos efetivos bem como serem capazes de monitorar e controlar os custos incorridos destas atividades.

O esforço de racionalização dos gastos e de aumento da produção realizado, parece ter obtido relativo êxito, no sentido de reequilibrar a economia do Hospital. Os recursos arrecadados com a prestação de serviços representavam em 1994, cerca de $68 \%$ das necessidades financeiras frente às despesas do hospital, já em 2000, estava em torno de $88 \%$. Quando tomamos como parâmetro somente as receitas provenientes do SUS, estes percentuais caem para $62 \%$ e $73 \%$, respectivamente, muito acima, entretanto, dos valores obtidos por IBAÑEZ et. al (2001) em hospitais 
paulistas, sob gestão de organizações sociais. Este estudo recente mostrou que a relação receita SUS e despesas girava entre $24 \%$ a $48 \%$ nos hospitais estudados. Ainda, segundo dados dos autores, em hospitais privados sem fins lucrativos, conveniados ao SUS, o padrão de despesas seria menor e o percentual de receita do SUS chegaria a cobrir mais de $50 \%$ das despesas.

Em relação às despesas chama atenção o expressivo crescimento dos gastos com o pagamento de profissionais médicos, como plantonistas. Uma hipótese levantada seria o pequeno número de professores médicos envolvidos com a rotina hospitalar, face à crescente demanda assistencial devida à inserção do Hospital no SUS - em especial o Pronto Atendimento, ou até mesmo, o pouco compromisso desses professores com as atividades eminentemente assistenciais. Isso estaria levando $\mathrm{O} \mathrm{HC}$ a contratar plantonistas para o atendimento da rotina assistencial, e em alguns casos pedagógica, com os médicos residentes. Por outro lado, destacamos o baixo valor gasto com material permanente. Este dado parece refletir a ausência de investimento, e conseqüentemente sucateamento, dos equipamentos, das tecnologias e das condições de atendimento ao paciente.

Ao discutirmos receitas (orçamento) e despesas ou custos de um hospital público universitário deveríamos ressaltar algumas de suas especificidades. Um ponto que deve ser destacado é a pluralidade de objetivo de um hospital universitário (assistência, ensino e pesquisa) e a complexidade dos pacientes que, geralmente, estão sob seu cuidado. Alguns dos aumentos de custos dos hospitais universitários são resultados da provisão de serviços adicionais, os denominados educação e pesquisa $\mathrm{O}$ escopo das atividades 
de ensino é bastante amplo, incluindo graduação e pós-graduação em medicina, bem como treinamento em variadas categorias profissionais de saúde. Nos Estados Unidos da América, em estudo realizado no final dos anos 80 , mostrou-se que o custo médio de um paciente do MEDICARE (seguro público americano para pessoas idosas e incapazes) era $95 \%$ maior em hospitais de ensino de grande porte do que em hospitais, sem ensino, do mesmo porte e $39 \%$ maior do que nos de ensino de pequeno porte (POTTER 2000). Em estudo realizado na Espanha, encontrou-se que o impacto nos custos do fator ensino dependia do número de residentes, com um aumento de $51 \%$ para hospitais com mais de 204 residentes e $42 \%$ com menos de 204 residentes (LÓPEZ-CASANOVAS e SAEZ 2000). Os altos custos dos hospitais de ensino são resultado tanto de custos diretos como indiretos. Custos indiretos são os resultantes do aumento de testes diagnósticos, do número de procedimentos realizados, maior número de funcionários. Alternativamente, custos diretos incluem: salários e bolsas de residentes, preceptores, salas especiais para aulas e conferências, equipamentos adicionais, etc. A alocação de recursos adicionais reconhece o fato que existem custos adicionais no ensino que não podem ser atribuídos diretamente à provisão de serviços de saúde (DUCKETT 1995; LÓPEZCASANOVAS E SAEZ 2000).

Além disto, hospitais de ensino tratam um mix de pacientes mais complexos, têm grande número de trabalhadores em variadas categorias profissionais e oferecem opções de tratamento mais extensivas (podem variar do cuidado básico até o terciário) e, portanto, mais dispendiosas. Como os hospitais 
públicos dentro de um sistema de saúde regionalizado e hierarquizado, os hospitais de ensino têm pouco poder para mudar os tipos de casos/pacientes internados, porque não thes é permitido selecionar pacientes. Os hospitais públicos são mais influenciados pela necessidade social, apresentam um grande volume de serviços, possivelmente, pouco lucrativos - pacientes crônicos e com média de permanência alta (ZWANZIGER et. al 1996; PUIG-JUNOY 1999; MIKKOLA et. al 2001). Desta maneira, os hospitais de ensino no Brasil, assim como em outros países, exibem altos custos por paciente tratado em comparação com outros hospitais, mesmo após a estandardização por casos tratados utilizando o grupo relacionado de diagnóstico - DRG. (DUCKETT 1995; ZUCCHI et. al 1998; POTTER 2000).

Parece que o aumento da produção hospitalar do $\mathrm{HC}$ se fez mais às expensas da incorporação de novos recursos humanos do que do aumento da produtividade de seus trabalhadores. No entanto, esta afirmativa pode incorrer em injustiça, uma vez que o absenteísmo, para algumas categorias profissionais ultrapassa os $33 \%$ (GODOY 2001). Por sua vez o indicador com a proporção de RH/leitos, que vem caindo nos últimos anos, situandose em torno de 7 funcionários por leito é igual ao dos hospitais públicos, mas distante da proporção dos hospitais privados e os sob gestão de organizações sociais (em torno de 5 funcionários por leito) (BITTAR 1997; ZUCCHI et. al 1998; IBAÑEZ et. al 2001). Segundo BITTAR (1997) a análise deste indicador mostra como os hospitais aproveitam sua mão-de-obra. 
A queda constante da média de permanência hospitalar, nos anos analisados acompanha o movimento geral de queda deste indicador ocorrida no mundo ocidental (DUCKETT 1995, BRAVEMAN 1997; GOUVEA et. al 1997; JORGE et. al 1998; ZUCCHI et. al 1998; POTTER 2000; MIKKOLA et. al 2001; IBAÑEZ et. al 2001, McKEE e HEALY 2002). Entre as possiveis explicações podemos citar a maior precisão e rapidez no diagnóstico, devido ao desenvolvimento dos serviços complementares; o desenvolvimento tecnológico ocorrido com drogas, órteses e próteses e novas tecnologias cirúrgicas que influenciam diretamente no tempo de internação necessário para o restabelecimento dos pacientes (BITTAR 1996). Outro fator determinante foi a utilização de controle de preços no sistema de saúde, especialmente a remuneração por diagnóstico, que têm incentivado os hospitais a darem alta mais precoces aos pacientes. Muitos pesquisadores têm discutido as implicações, para a saúde e recuperação dos pacientes, da redução da média de permanência (DUCKETT 1995; BRAVEMAN 1997; POTTER 2000, MIKKOLA et. al 2001). É interessante notar que apesar da queda da média de permanência no HC para 5,5 dias, ela é maior do que em hospitais privados brasileiros de mesma complexidade (3,7 dias) e próxima de alguns hospitais sob organizações sociais (BITTAR 1996; ZUCCHI et. al 1998; IBAÑEZ et. al 2001). Como já referido os hospitais públicos de ensino são mais influenciados pela necessidade social, atendendo pacientes crônicos, com patologias mais graves, sem suporte familiar ou da comunidade para uma alta precoce, o que, sem dúvida, irá influenciar a média de permanência. 
Segundo MALIK e TELES (2001) dados de hospitais privados que atendem somente pacientes com cobertura de saúde suplementar (planos de saúde) e de desembolso direto mostraram uma taxa de ocupação em torno de $90 \%$, ainda que em alguns hospitais financiados pelo SUS esta taxa tenha caído nos últimos anos. A taxa de ocupação do $\mathrm{HC}$, entretanto, está em torno de $70 \%$, sendo que em algumas clínicas está abaixo deste percentual. A taxa do CTI pediátrico, por sua vez, está próxima dos $100 \%$ evidenciando a demanda reprimida nessa especialidade (MALIK e TELES 2001).

\subsection{PERCEPÇÃO, INCORPORAÇÃO, RESISTÊNCIA E REDEFINIÇÃO DO CONCEITO DE EFICIÊNCIA PELOS TRABALHADORES E GERÊNCIA}

$\mathrm{Na}$ análise da percepção, incorporação, resistência e redefinição do conceito podemos notar que trabalhadores e gerência do HC selecionaram, organizaram e interpretaram o conceito de eficiência propugnado pelo MARE, incorporando seletivamente alguns aspectos, resistindo a outros e até mesmo redefinindo o conceito de eficiência.

Apesar de declararem ter pouco conhecimento sobre a reforma do Estado, parece que, em relação ao conceito de eficiência, houve um grande "bombardeio", uma vez que todos os entrevistados vocalizaram um conceito, em vários aspectos parecido com os ditames da reforma do Estado, como a afirmação de que seria indispensável que o $\mathrm{HC}$ ou um hospital público fosse eficiente para que cumprisse sua missão institucional. Mesmo determinados aspectos da reforma, que atingiam pessoalmente os trabalhadores, como a previdência, foram menos verbalizados. Segundo HERNANDEZ e CALDAS 
(2001) o processo de percepção e incorporação dependeria da quantidade e qualidade dos estímulos interiores e exteriores. O longo processo de reorganização do HC aliado à intensificação da reforma do Estado criaram um ambiente propício para que o conceito de eficiência fosse discutido e, até mesmo, que resistências fossem quebradas.

É interessante observar que determinados valores relacionados à eficiência colocados nos documentos do MARE também são comungados pelos trabalhadores e gerência do $\mathrm{HC}$, como a necessidade de atender a sociedade, o atendimento ao cidadão/cliente visto como satisfação do usuário, no nível gerencial: a necessidade de autonomia, uma gerencia profissional e descentralizada, participativa e com bom desempenho.

"Eu acho que para um hospital, eficiência está ligada ao melhor tipo de atendimento que pode ser dado ao cliente. Ele é o ponto de referência, ele é o objetivo do hospital, então, esse atendimento deve ser dado com eficiência e eficácia”. (Entrevista)

"Eu acho que o conceito de eficiência pressupõe uma outra coisa também. Se for só a eficiência sem participação, só uma eficiência gerencial, ela é também ineficaz. Ela pode surtir efeito durante um certo tempo, mas se esvai. Por exemplo, esse projeto de unidade funcional, se ela não for tomada pelas pessoas, quer dizer, se essa eficiência não for também a eficiência da participação democrática das pessoas, realmente de participar do processo, ela se esvai. A eficiência, então, automaticamente, pressupõe, está embutido nele um conceito de participação - não sei se eu poderia chamar de democracia, mas de participação." (Entrevista)

Dois vocábulos (valores) vão estar presentes como conectados ao conceito de eficiência, seja no discurso dos trabalhadores, gerencia e documentos do HC, seja no do MARE: otimização e qualidade. A otimização (de recursos) vai ser a face econômica mais explícita da eficiência, para a direção e trabalhadores do $\mathrm{HC}$, revelando, talvez, uma dissimulação do caráter econômico da eficiência em um hospital universitário público. Segundo 
VAITSMAN (2001) uma das características da cultura brasileira seria a capacidade de misturar elementos de diferentes mundos práticos e simbólicos, o que estaria incorporado no modo brasileiro de agir na vida cotidiana em suas instituições e relações sociais. Assim está expresso no objetivo do novo modelo de gestão, as Unidades Funcionais:

"Esta estrutura gerencial visa otimizar a gestão dos recursos humanos, financeiros e materiais, bem como as ações de planejamento que implicam na definição de prioridades, elaboração de indicadores e definição de metas assistenciais, financeiras, de ensino, pesquisa e extensão" (Plano Diretor do HC 2000-2002)

Por sua vez existiria uma diferença entre a percepção dos trabalhadores e gerência do $\mathrm{HC}$ e dos documentos do MARE sobre a relação entre eficiência e qualidade. Para os primeiros a qualidade é um valor intrínseco ao conceito de eficiência, talvez pela natureza do trabalho em saúde, enquanto para o MARE a eficiência seria uma qualidade racionalizada (com menor custo).

"Para mim uma coisa só é eficiente se ela tiver qualidade. Ele pode ser lucrativo, outras coisas, mas não eficiência. Eficiência para mim tem que ter qualidade junto." (Entrevista)

"O objetivo da reforma é permitir que a administração pública se torne mais eficiente e ofereça ao cidadão mais serviços, com maior qualidade. Ou seja, fazer mais e melhor com os recursos disponiveis" (BRASIL 1997. Cademos MARE da reforma do estado; c. 6, p. 10).

Uma redefinição importante feita por trabalhadores e gerentes foi a relativização e subjetivação do conceito de eficiência: a eficiência possível, circunstanciada. Reintroduzem no conceito de eficiência as condições necessárias, ou pressupostas, para que o melhor desempenho ocorra.

"A questão de eficiência hoje, eu fico analisando, é atingir um determinado resultado. Meu objetivo é manter o atendimento. $100 \%$ seria eu atender da forma como o usuário espera, mas 
como eu não tenho condição, no presente momento, dado (risos) ao meu meio de trabalho, às deficiências que eu tenho, eu ainda acho que estou sendo eficiente. Agora, se você fizer uma pesquisa de cima para baixo e perguntar se eu estou sendo eficiente, eu acho que isso vai ser relativo, na visão deles vai ser que eu estou sendo ineficiente. Depende da visão. Dadas as circunstâncias, os resultados que eu estou alcançando com os meios que eu disponho, eu estou sendo eficiente, o meu setor está sendo eficiente. Em termos do meu trabalho, da minha forma, eu acho que estou sendo eficiente. Mas quando você começa a analisar de fora para dentro, o nivel de expectativa da pessoa com relação ao trabalho, ao resultado alcançado, eu acho que não. Por isso eu estou falando que a questão da eficiência é relativa, depende da perspectiva".

Por outro lado, os entrevistados chamam atenção para a diferença entre a medida da eficiência em um hospital público e privado e em um hospital universitário, que tem múltiplo objetivo. POTTER (2000), argumenta que a orientação de uma organização para o lucro influi nos seus resultados (eficiência). Hospitais lucrativos têm seu foco no mercado e em critérios econômicos enquanto que os públicos têm critérios mais ambíguos e múltiplos. Além disso, seu processo decisório e governança são mais complexos, pois envolvem as preferências de vários decisores. A diretoria, mais do que um único ator é constituída de múltiplos atores que, provavelmente, têm diferentes preferências. As decisões da diretoria irão refletir as diferenças de atores individuais.

"Se o conceito de eficiência for amplo, ele deve ser eficiente em tudo. Agora, se o conceito de eficiência for numérico ai ele não pode ser eficiente, por exemplo, no ambulatório como eu exemplifiquei, não tem como. Como ele vai ser eficiente também na produção, entre aspas, de atos cirúrgicos? Porque um ato cirúrgico num hospital comum pode ser feito por uma equipe de cirurgiões em uma hora e meia. No HC ele dura três horas, é evidente, tem um residente que está aprendendo e a relação é um para um, é um medico, um professor para um residente. Não tem jeito de ensinar dois, três, ao mesmo tempo. Então, o ato em si se toma ineficiente, se você raciocinar em eficiência apenas como um produto final, e mesmo de qualidade. Você está vendo como é 
importante? Num hospital público, no caso universitário, ele ainda tem esse caráter." (Entrevista)

"Tem inúmeros exemplos no mundo inteiro. O primeiro é ter clareza de que nunca vai dar lucro, que o sistema de saúde não dá lucro, então alguém tem que bancar isso. Eu acho que a primeira idéia é essa. Achar que um hospital público vai dar lucro, eu acho que para mim é um pressuposto equivocado. Não tem jeito. Ele pode ser eficiente, mas não dar lucro. A questão de ele ser eficiente, ele tem que partir de um pressuposto que ele não pode ser auto-sustentado, por si próprio, não tem jeito de ser. $E$ para ser eficiente, por exemplo, atendendo cuidados terciários, quatemários, tecnologia de ponta, procedimentos de alta complexidade, como é a proposta do hospital, isso tem que ter apoio, não adianta. Nunca vai conseguir fazer isso se não tiver. Então, ele tem que ter dinheiro para investimento tem que ter dinheiro para manter corpo clínico competente, etc. O fato dele ser hospital universitário favorece isso, está ligado a ensino, porque isso não permite que a qualidade e a competência seja ruim, tem que ser boa, automaticamente. Então, acho que isso é um bom modo de manter um hospital público eficiente." (Entrevista)

Além disso, dado o grau de contigencialidade que acompanha o trabalho médico, as regras formais do hospital são mais táticas do que explícitas, não especificas quanto às situações a que se aplicam, por quem, e até a que sanções dão lugar quando infringidas. Concebidas para se ajustarem o mais possivel às múltiplas situações particulares, acabam por deixar a descoberto amplas clareiras de não regulação, rapidamente ocupadas e reguladas por quem detém mais poder e mais influência. Também, dada a rapidez das mudanças na vida do hospital, estas regras caem facilmente em desuso, sendo substituídas por regras informais ou então sendo objeto de reapropriação administrativa (CARAPINHEIRO 1998)

As mudanças no financiamento e as alternativas encontradas pelo $\mathrm{HC}$ para contornar as dificuldades decorrentes são vistas até mesmo como positivas, pois impulsionaram um processo de reestruturação e reorganização gerencial do $\mathrm{HC}$, levando à racionalização de custo e à "necessidade" de 
eficiência. O tempo do desperdício estaria ficando para trás. Esta percepção vai ao encontro da noção de "folga organizacional" proposta por Hischmann e utilizada por COSTA et. al (2000) para tentar explicar a manutenção da ineficiência e do baixo empenho dos hospitais públicos nos anos 90 .

\begin{abstract}
"Então, o que aconteceu? Com essa diminuição do financiamento do hospital, o hospital foi obrigado, já que havia uma limitação de orçamento e uma dependência cada vez maior dos próprios recursos para poder manter o hospital, houve uma implementação de determinadas medidas que agora culminam nesse processo de unidades funcionais, um processo de melhoria da gerência. (...) Claro que o único fator não foi a reforma do estado, houve também a consciência que não era correto manter um paciente no hospital por um tempo maior que o necessário para fazer as intervenções que eram necessárias. A gente nota, ao longo do tempo, principalmente agora mais recente, um aumento da taxa de ocupação e a diminuição do tempo de permanência. Isso é uma mudança muito grande no processo de trabalho lá dentro. Eu acho que isso fundamentalmente foi motivado, não por achar que isso era o mais correto, mas porque foi forçado devido à situação de penúria financeira. Foi obrigado a tomar medidas. O desperdicio diminuiu brutalmente, as compras melhoraram sensivelmente, comprar melhor, saber comparar melhor. Então, a crise de financiamento trouxe como conseqüência uma melhoria da gerência." (Entrevista)
\end{abstract}

"Paralelamente a essa situação que ocomia, havia realmente questões gerenciais que independem se era financiada pelo Estado, se era pouco financiada, etc. O pessoal sentiu que havia desperdicio, as pessoas sentiam que a eficiência, mesmo em relação à capacidade instalada, era pequena. Principalmente por parte dos professores principalmente médicos, porque enfermagem tem muito pouco professor lá dentro - mas por parte dos funcionários houve uma certa resistência, mas não houve, porque vamos dizer assim, porque realmente havia vamos chamar de deficit gerencial." (Entrevista)

É digno de nota que apesar do conceito de eficiência estar bastante presente no discurso do $\mathrm{HC}$, carece, as vezes, de ressonância prática. $\mathrm{O}$ aumento da produtividade dos trabalhadores é pouco sinignificativa e a taxa de absenteísmo é bastante elevada. $O$ aumento da produção se fez, muitas vezes, com a incorporação de novos trabalhadores. Segundo VAITSMAN (2001) o servidor público se localiza e orienta suas ações em um ambiente 
paradoxal e conflitante, onde universalismo e meritrocracia chocam-se com diversas manifestações da lógica particularista que é acionada sempre que possivel.

É consenso que os anos 90 trouxeram mudanças, em especial para as organizações e os trabalhadores do setor público de saúde. A municipalização e a mudança na forma de financiamento dos hospitais universitários federais são lembrados como os fatores mais importantes a influir na vida do $\mathrm{HC}$ nestes tempos de reforma.

Observação interessante é a de que a reforma setorial da saúde parece ter trazido um impacto mais substantivo na reestruturação do Hospital do que a "reforma maior" a do Estado. Com o processo de municipalização dos serviços de saúde de Belo Horizonte, consolidado no início de 1993, a Secretaria Municipal de Saúde de Belo Horizonte (SMS/BH) passa de simples prestadora de serviços a gestora de todo o sistema de saúde, controlando a quase totalidade das ações de saúde desenvolvidas no municipio, com a prerrogativa de administrar o pagamento dos prestadores controlados e conveniados ao SUS. Ao assumir a condição de gestora do SUS em Belo Horizonte, a SMS/BH torna-se a principal fonte de recursos (financiador/regulador/comprador de serviços) e ator chave da relação com os provedores de serviços de saúde no município e em especial com o HC (CAMPOS et. al 1998).

A "abertura para o SUS", a partir do estabelecimento de uma nova relação entre a SMS/BH e o HC, corporificada na criação do Pronto Atendimento 
Clínico, em 1996, vai significar para grande maioria dos trabalhadores, gerencia e diretoria profundas mudanças na organização e no próprio comportamento das pessoas. Nas palavras de um entrevistado;

"Ai foi feito um acordo (da Secretaria Municipal de Saúde) com o hospital, de dar dinheiro para o hospital, para o hospital realmente criar o pronto atendimento dele. Eu acho que esse foi um marco que mudou substancialmente, porque aí obrigou o hospital a se inserir no SUS."

Como vimos, os hospitais universitários vêm tornando-se importantes parceiros do SUS, com crescimento expressivo do número de internações e procedimentos realizados nestes hospitais (GOUVEA et. al 1997; JORGE et. al 1998). A importância dessa parceira foi assim expressa por um entrevistado:

"Para mim essa mudança do hospital, de ser um hospital universitário, naquele modelo antigo de hospital universitário para um hospital do SUS mesmo, atendendo à demanda do SUS, respondendo muito mais ao SUS do que à própria universidade, porque muitas vezes a gente responde mais ao gestor do que ao reitor. Ás vezes a gente tem mais interesse em ter uma boa relação com o gestor, às vezes até do que com o próprio reitor, porque o reitor mais ou menos vocé consegue conviver, por justiça nós nunca tivemos problemas na relação com o reitor, mas se tivesse, mas com o gestor nós tivemos problema de relação e é complicadíssimo, porque é quem nos sustenta aqui. Isso mudou totalmente a situação do hospital." (Entrevista)

A mudança da política de financiamento do governo federal é apontada, por unanimidade dos entrevistados, como a responsável pela "abertura para os planos e seguros de saúde", destinando $30 \%$ de seus leitos para essa clientela. Todos a justificam como a possibilidade de manter o $\mathrm{HC}$ funcionando, aberto para SUS. COHN (1999) referindo-se à mesma medida tomada pelo HC/USP questiona se esta política, sem o devido controle social, não levaria à "privatização dos serviços" por práticas gerenciais que 
permitissem a seletividade do acesso da clientela. Temor, este, partilhado pelos entrevistados.

“(...) Então a politica do govemo está sendo implantada da forma mais penversa do mundo. Ele está nos obrigando a receber a privatização por dentro, ou seja, dar acesso aos seguros de saúde privado, de uma forma privilegiada, em leitos exclusivos, para que a gente tenha condição de atender uma maioria de leitos públicos. Então, é muito contraditório o que a gente está vivendo, mas é o que está acontecendo." (Entrevista)

“(...) Então, a gente começa a utilizar a mesma metodologia que a gente sempre criticou há anos atrás, que é a metodologia da sobrevivência capitalista mesmo: o que se paga melhor então a gente vai estar atendendo, o que se paga pior a gente vai estar tentando segurar. Ou seja, segurando no pronto atendimento para poder mandar para a central de leitos, para poder evitar que esses pacientes entrem aqui, porque a caracteristica do hospital universitário é realmente de atender os casos mais complexos e hoje isso está significando a inviabilidade do funcionamento do hospital. (....)" (Entrevista)

As mudanças gerenciais são voltadas para a busca da responsabilização, da descentralização, da eficiência, da flexibilização, da agilidade na tomada e na implantação de uma decisão (governança) para atender as demandas dos novos parceiros (gestor municipal e estadual) e planos e seguros privados de saúde. É interessante notar que elas trazem algumas das propostas consideradas fundamentais pela "nova administração pública". Parece que o processo de institucionalização do valor da eficiência encontrase bem sedimentado, alcançando o status institucional, não requerendo ações evidentes para dar continuidade a sua existência SCOTT (1987).

“(...) Porque um hospital particular dá lucro e um hospital público não dá?. Eu sempre pensei em um hospital como uma empresa. O Hospital da Clínicas tem as características próprias, mas ele é uma empresa, e como empresa ele tem que ter condições de se auto-sustentar. Quer dizer, tem determinadas nuances, de pertencer à rede SUS, que você tem que respeitar, os convênios que o hospital faz, o custo do ensino, tem a questão da pesquisa e tudo mais." (Entrevista) 
As resistências às mudanças narradas são de toda a ordem, e de todas as categorias profissionais. Os professores/médicos resistem passivamente não se inserindo nos debates, os profissionais de enfermagem tentam delimitar seu poder em posições "fechadas" dentro da categoria, os administrativos com a morosidade dos processos. Segundo CECÍLIO (1997 e 1999) o grau de resistência ou oposição é proporcional à estrutura previamente existente. Quanto mais estruturados os corpos funcionais em organogramas formais, maior seria a dificuldade de mudança. Observamos que os três segmentos são bastante estruturados no $\mathrm{HC}$, o que poderia representar maior dificuldade na implementação das mudanças. No entanto, MALIK e TELES (2001) em estudo sobre a utilização de iniciativas de qualidade em hospitais, encontraram uma atitude favorável à implantação destas iniciativas por parte do corpo funcional. Talvez seja essa a percepção da gerência do HC ao afirmar:

"Houve, não, há, em grande quantidade, de toda as ordens e de todos os niveis, entre professores, entre funcionários, há grandes resistências entre a estrutura de enfermagem. Isso a gente observa todos os dias, em pequenos atos. Agora, também, elas não têm sido resistências intransponiveis, não. Está havendo um certo acolhimento dessas propostas de mudança." (Entrevista)

HERNANDEZ e CALDAS (2001) em revisão crítica sobre o tema da resistência à mudança - um dos tópicos mais estudados no campo organizacional - contestam pressupostos comumente relacionados à resistência como: (i) um fato natural e inevitável; (ii) algo nocivo às organizações e às iniciativas de mudança; (iii) algo que ocorre apenas entre empregados e (iv) um fenômeno massificado. Segundo os autores a resistência pode ser um fenômeno positivo, saudável e contributivo. 
Portanto, algumas resistências relatadas podem ser uma oportunidade de se repensar os caminhos propostos.

"Com a mudança das marcações de consulta pela central de marcação, acabou isso, acabaram as filas, porém dificultou mais o acesso das pessoas ao hospital. Então, existem clínicas que têm uma resistência. Não estão querendo colocar a marcação deles para a central. Porque? Porque não está bom, não está legal. Então, eu acho que em alguns aspectos existem resistências sim, com relação a algumas mudanças. Porque se fosse para melhorar, eu acho que tudo que é para melhorar a gente tem que ficar aberto, mas quando você vê que não está dando resultado, ai a pessoa fica realmente resistente nesse ponto." (Entrevista)

Para CARAPINHEIRO (1998) a sensibilização e a aderência às politicas de racionalização dos recursos têm sido progressivas, notando-se maior permeabilidade dos vários grupos profissionais aos problemas da gestão hospitalar, nomeadamente dos médicos, mas neste caso estabelecendo-se medidas cautelares da autonomia na gestão dos serviços. 


\section{CONSIDERAÇÕES FINAIS}

Demonstramos que o discurso da reforma setorial do Estado brasileiro, implementada a partir dos anos 90 , com seu pressuposto eficientista priorizando a urgência econômica, tornou-se prática cotidiana e até mesmo salvadora para as instituições públicas de saúde. Desvelamos a transplantação para o interior do hospital de critérios e práticas eficientistas propugnadas por essa reforma do Estado. Parece que seu conteúdo "ideologizante" alcançou o objetivo.

Constatamos que o conceito de eficiência, imanente na reforma do Estado (e setorial) brasileira, independentemente de sua roupagem, tem-se alinhado à limitação estreita do cálculo econômico, não abrangendo, portanto, critérios de eficiência coletiva ou social, num "cálculo econômico entre o "possivel" e o "necessário".

Verificamos que a reforma setorial da saúde trouxe um impacto mais substantivo na reestruturação do Hospital do que a "reforma maior", a do Estado. Constatamos que o "quase-mercado" defendido pela reforma setorial é uma realidade no setor hospitalar brasileiro. Os hospitais públicos têm competido entre si e com os privados no "mercado SUS", desde o início da década dos noventa. O processo de municipalização dos serviços de saúde tornou este mercado mais visível e transparente devido à proximidade entre o gestor municipal e os prestadores de serviços. Confirmamos que dependendo do maior ou menor grau de publicização ou privatização das 
decisões do gestor local, maior ou menor prioridade seria dada ao prestador público.

Verificamos o esforço que o Hospital das Clínicas tem feito para se legitimar e se adaptar às novas demandas e restrições impostas pela reforma do Estado. As mudanças organizacionais e na produção do $\mathrm{HC}$ refletem a tentativa do Hospital de proteger os serviços centrais por ele oferecidos (assistência, ensino e pesquisa) em um ambiente de escassez de recursos e mudanças do padrão de regulação. Esta estratégia de proteção incluiu, por exemplo, táticas como a busca de fontes alternativas de financiamento em face dos cortes de recursos orçamentários provenientes do MEC. Uma outra estratégia foi a adoção de um conjunto de procedimentos com o objetivo de cortar custos operacionais, em atividades consideradas não prioritárias, e aumentar a produção de serviços. Em ambos os casos, o objetivo foi preservar os resultados $e$ as atividades ofertadas apesar da redução dos recursos. Entretanto, esta economia operacional é apenas uma medida paliativa que não pode ser freqüentemente repetida ou sustentada diante de persistentes cortes de recursos públicos.

Notamos que, ao mesmo tempo, tem-se modificado a fisionomia de sua clientela, integrando classes sociais com maiores exigências de qualidade dos atos médicos e com expectativas do hospital como lugar de alta tecnicidade e organizado sob novas formas de racionalidade e eficácia. Estes processos de mudanças solicitam o abandono das fórmulas ancestrais de gestão hospitalar, tornando-a mais flexível à emergência de novas 
estruturas de poder e a novos rearranjos na relação de forças entre os diversos grupos profissionais que se movimentam no hospital.

Nesse sentido, o HC/UFMG deu um passo a mais realizando uma reengenharia em sua organização e cultura, através da implantação das Unidades Funcionais. Esta estratégia tem significado uma mudança fundamental nas atividades centrais do Hospital, sendo maior do que um simples corte seletivo, pois inclui investimento nas operações/atividades, isto é, implementação de novo sistema gerencial e aquisição de tecnologias avançadas para tratamento dos pacientes, capacitação e desenvolvimento dos seus trabalhadores. Por outro lado, investiu também na reestruturação de serviços com medidas como fechamento ou abertura de unidades de serviços, maior especialização em certas áreas com potencial de mercado, novas formas de incentivo à produtividade do trabalhador, protocolos de práticas, trazendo implicações importantes para o ambiente interno e externo.

Percebemos que o esforço de aumento de produção e redução dos desperdícios tem se tornado uma política relativamente exitosa: houve aumento significativo da produção hospitalar e em menor grau da ambulatorial, aumento da taxa de ocupação e queda na média de permanência; estabilização das despesas e redução consistente de seu deficit, com ampliação de suas fontes de receitas. No entanto, a discrepância entre o crescimento da produção ambulatorial e hospitalar nos faz questionar o porque do HC se colocar na contra-mão das tendências observadas no setor saúde: o aumento da provisão de serviços 
ambulatoriais e até de serviços domiciliares. Até que ponto a ausência de financiamento público, via orçamento, em conjunto com as alternativas racionalizadoras e a busca de recursos no mercado privado de saúde, não levariam à seletividade da clientela e à perda da equidade no atendimento? O novo modelo organizacional, as Unidades Funcionais se baseiam em principios gerenciais similares aos da reforma do Estado, como descentralização, autonomia, contrato de gestão, passível, portanto das mesmas críticas. Como evitar ou minimizar os riscos de autonomização, despolitização e contratualização das relações e subversão dos fins prioritários da instituição em um ambiente propício ao seu desenvolvimento como os serviços hospitalares? Como fazer para que a "sobrevivência" do HC não se transforme numa vitória de Pirro?

Verificamos, ainda, a incorporação do conceito de eficiência pelos trabalhadores do HC/UFMG. A princípio numa assimilação seletiva, com pontos de resistência, mas, sem dúvida também capaz de redefini-lo agregando-o a aspectos fundamentais do cotidiano de seu trabalho, como a agilidade e presteza. Constroem a eficiência possivel, circunstanciada através da relativização e subjetivação do conceito de eficiência.

Contudo, as constantes mudanças das "regras do jogo", nessa década de reforma, tem gerado um sentimento de incerteza nos trabalhadores públicos, - que propicia que os valores eficientistas, de comprometimento e de responsabilização com o serviço público, bastante claro nos discursos dos trabalhadores do HC/UFMG, se tornem apenas peça de retórica, pois não se institucionalizam de forma generalizada nos comportamentos e práticas do 
dia-a-dia. A alta taxa de absenteísmo, referida por todos os trabalhadores, não corrói somente a produtividade e as relações entre trabalhadores $e$ gerência e inter-trabalho, mas ameaça a sobrevivência do próprio HC.

Como motivar e comprometer os servidores, se o sentimento preponderante é o da insegurança, desconfiança e iniqüidade? Como transformar em adesão e prática os valores e representações de eficiência explícitos nos discursos, o que implicaria uma política de recursos humanos que valorizasse o servidor público? Estaria a implementação de uma tal politica na alçada dos diretores do HC/UFMG?

Verificamos que a suplantação do social pelo econômico, tem gerado mais ceticismo sobre as soluções coletivas, a despolitização do setor público e mais conflitos sobre o que é público. Reafirmamos, portanto, que num processo de redesenho das funções do Estado e do papel das organizações públicas, valores e metas finalísticas de justiça social, equidade e promoção de oportunidades - e não apenas o cumprimento de metas eficientistas - são princípios inarredáveis. Esse é o grande desafio a ser enfrentado pelas instituições públicas de saúde. 


\section{REFERÊNCIAS}

Aday LA, Begley CE, Lairson DR, Slater CH. 1998. Evaluating the health care system: effectiveness, efficiency and equity. $2^{a}$ ed. Chicago: HSR. $334 p$.

Almeida CM. 1999. Reforma do Estado e reforma do sistema de saúde: experiências internacionais e tendências de mudança. Ciência \& Saúde Coletiva. 4:263-286.

Andrews CW, Kouzmin A. 1998. O discurso da nova administração pública. Lua Nova 45:97-129.

Azevedo S, Andrade LAG. 1997. A reforma do Estado e a questão federalista: reflexões sobre a proposta Bresser Pereira. In Diniz E, Azevedo S. (Org). Reforma do Estado e democracia no Brasil: dilemas e perspectivas. Brasília: UNB. P.57-80.

Barbosa PR. 1996. Gestão de hospitais públicos: maior autonomia gerencial, melhor performance organizacional com apoio em contratos de gestão. RSP 120(2):67-97.

Barros E. 1996. Política de Saúde no Brasil: a universalização tardia como possibilidade de construção do novo. Ciência \& Saúde Coletiva (1) 1: 5 17.

Bauman Z. 1999. Globalização: as conseqüências humanas. Rio de Janeiro: Jorge Zahar, 145p.

Bittar OJ. 1996. Produtividade em hospitais de acordo com alguns indicadores hospitalares. Rev. Saúde Pública 30(1)53-60.

Bittar, OJ. Nogueira V. 1997. Distribuição dos recursos humanos em oito hospitais gerais de São Paulo. Rev Panam Salud Publica, 2(1)123-132.

Bobbio N. 1992. Dicionário de política. $4^{a}$ ed. Brasília: Edições Universidade de Brasília, p.407-408.

Borges A. 2000. Ética Burocrática, Mercado e Ideologia Administrativa: Contradições da Resposta Conservadora à "Crise de Caráter" do Estado* Dados, 43(1):119-151.

Brasil. 1988. Constituição Federal. art. 24,XII c.c., art.30,II.

Brasil. 1995. Plano Diretor da Reforma do Aparelho do Estado. Brasília: Presidência da República, Câmara da Reforma do Estado, Ministério da Administração Federal e Reforma do Estado, 86p. 
Brasil. 1997. Ministério da Administração Federal e Reforma do Estado. Exposição no senado sobre a reforma da administração pública. Ministério da Administração Federal e Reforma do Estado. Brasília: MARE, 42p. (Cadernos MARE da reforma do estado, c. 3)

Brasil. 1997. Ministério da Administração Federal e Reforma do Estado. Programa da qualidade e participação na administração pública. Ministério da Administração Federal e Reforma do Estado. Brasilia: MARE, $59 \mathrm{p}$ (Cadernos MARE da reforma do estado, c. 4)

Brasil. 1997. Ministério da Administração Federal e Reforma do Estado. Plano de reestruturação e melhoria da gestão do MARE. Ministério da Administração Federal e Reforma do Estado. Brasilia: MARE, $39 \mathrm{p}$ (Cadernos MARE da reforma do estado, c. 5)

Brasil. 1997. Ministério da Administração Federal e Reforma do Estado. A Reforma do aparelho do estado e as mudanças constitucionais: síntese \& resposta a dúvidas mais comuns. Ministério da Administração Federal e Reforma do Estado. Brasília: MARE, $23 \mathrm{p}$ (Cadernos MARE da reforma do estado, c. 6)

Brasil. 1997. Ministério da Administração Federal e Reforma do Estado. A Reforma administrativa na imprensa. Ministério da Administração Federal e Reforma do Estado. Brasilia: MARE,. 81p. (Cadernos MARE da reforma do estado, c. 7)

Brasil. 1997. Ministério da Administração Federal e Reforma do Estado. Conselho de reforma do estado. Ministério da Administração Federal e Reforma do Estado. Brasilia: MARE, 38p. (Cadernos MARE da reforma do estado, c. 8)

Brasil. 1997. Ministério da Administração Federal e Reforma do Estado. Agências executivas. Ministério da Administração Federal e Reforma do Estado. Brasília: MARE, $54 \mathrm{p}$ (Cadernos MARE da reforma do estado, c. 9)

Brasil. 1997. Ministério da Administração Federal e Reforma do Estado. Questões sobre a reforma administrativa: respostas a questões formuladas pela Comissão Especial da Câmara dos Deputados, destinada a proferir parecer à $P E C n^{\circ} 173-A$ 95, em reunião realizada no dia 7 de dezembro de 1995. Ministério da Administração Federal e Reforma do Estado. Brasília: MARE, 23 p (Cadernos MARE da reforma do estado, c. 10)

Brasil. 1997. Ministério da Administração Federal e Reforma do Estado. A Nova politica de recursos humanos. Ministério da Administração Federal e Reforma do Estado. Brasília: MARE, $48 \mathrm{p}$ (Cadernos MARE da reforma do estado, c. 11) 
Brasil. 1998. Ministério da Administração Federal e Reforma do Estado. Organizações sociais. Ministério da Administração Federal e Reforma do Estado. Brasília: MARE, $4^{\circ}$ ed. $72 p$. (Cadernos MARE da reforma do estado, c. 2)

Brasil. 1998. Ministério da Administração Federal e Reforma do Estado. Programa de reestruturação e qualidade dos ministérios. Ministério da Administração Federal e Reforma do Estado. Brasília: MARE, 47p. (Cadernos MARE da reforma do estado, c. 12)

Brasil. 1998. Ministério da Administração Federal e Reforma do Estado. A Reforma administrativa do sistema de saúde. Ministério da Administração Federal e Reforma do Estado. Brasília: MARE, 33p. (Cadernos MARE da reforma do estado, c. 13)

Brasil. 1998. Ministério da Administração Federal e Reforma do Estado. Regime jurídico único consolidado (Lei $n^{\circ} 8.112$, de 11/12/90). Ministério da Administração Federal e Reforma do Estado. Brasília: MARE, 115p. (Cadernos MARE da reforma do estado, c. 14)

Brasil. 1998. Ministério da Administração Federal e Reforma do Estado. Os Avanços da reforma na administração. Ministério da Administração Federal e Reforma do Estado. Brasília: MARE, 127p. (Cadernos MARE da reforma do estado, c. 15)

Brasil. 1998. Ministério da Administração Federal e Reforma do Estado. Programa de modemização do poder executivo federal. Brasília: MARE, $70 \mathrm{p}$ (Cadernos MARE da reforma do estado, c. 16)

Brasil. 1998. Ministério da Administração Federal e Reforma do Estado. Serviço Integrado de Atendimento ao Cidadão. Brasilia: MARE, $54 \mathrm{p}$ (Cadernos MARE da reforma do estado, c. 17)

Brasil. Decreto n. 1.590, de 10 de Agosto de 1995. Dispõe sobre a jornada de trabalho dos servidores da Administração Pública Federal direta, das autarquias e das fundaçōes públicas federais, e dá outras providências. Diário Oficial da União, Brasilia, 11 ago. 1998. Col. 1, p. 000001.

Brasil. Emenda Constitucional n. 20, de 15 de dezembro de 1998. Modifica o sistema de previdência social, estabelece normas de transiçăo e dá outras providências. Diário Oficial da União, Brasília, 16 dez. 1998. Col. 1, p. 000001.

Brasil. Emenda Constitucional n. 19, de 04 de julho de 1998. Modifica o regime e dispõe sobre princípios e normas da Administração Pública, servidores e agentes politicos, controle de despesas e finanças públicas e custeio de atividades a cargo do Distrito Federal, e dá outras providências. Diário Oficial da União, Brasília, 5 jul. 1998. Col. 1, p. 000001. 
Brasil. Lei n. 9.962, de 22 de fevereiro de 2000. Disciplina o regime de emprego público do pessoal da Administração federal direta, autárquica e fundacional e dá outras providências. Diário Oficial da União, Brasilia, 22 fev. 2000. Col. 1, p. 000001.

Brasil. Lei n. 9637, de 15 de Agosto de 1998. Dispõe sobre a qualificação de entidades como organizações sociais, a criação do Programa Nacional de Publicação, a extinção dos órgãos e entidades que menciona e a absorção de suas atividades por organizações sociais e dá outras providências. Diário Oficial da União, Brasília, 18 ago. 1998. Col. 1, p. 000008.

Brasil. Lei n. 9717, de 27 de Novembro de 1998. Dispōe sobre regras gerais para a organização e o funcionamento dos regimes próprios de previdência social dos servidores públicos da União, dos Estados, do Distrito Federal e dos Municipios, dos militares dos Estados e do Distrito Federal e dá outras providências. Diário Oficial da União, Brasília, 28 nov. 1998. Col. 1, p. 000001.

Brasil. Lei n. 9783, de 28 de Janeiro de 1999 Dispõe sobre a contribuição para o custeio da previdência social dos servidores públicos, ativos e inativos, e dos pensionistas dos Três Poderes da União. Diário Oficial da União, Brasilia, 29 jan. 1999. Col. 1, p. 000001.

Brasil. Lei n. 9801, de 16 de junho de 1999. Dispõe sobre a exoneração de servidor público estável com fundamento no $\S 4^{\circ}$ e seguinte do art. 169 da Constituição Federal e dá outras providências. Diário Oficial da União, Brasilia, 17 jun. 1999. Col. 1, p. 000001.

Brasil. Lei Complementar n. 101, de 04 de maio de 2000. Estabelece normas de finanças públicas voltadas para a responsabilidade na gestão fiscal e dá outras providências. Diário Oficial da União, Brasilia, 5 mai. 2000. Col. 1, p. 000001.

Brasil. Lei Complementar n. 96 de 31 de Maio de 1999. Disciplina os limites das despesas com pessoal, na forma do art. 169 da Constituição e dá outras providências. Diário Oficial da União, Brasilia, 1 jun. 1999. Col. 1, p. 000001.

Brasil. Lei n. 9.649, 27 de maio de 1998. Dispõe sobre a organização da Presidência da República e dos Ministérios e dá outras providências. Diário Oficial da União, Brasília, 28 mai. 1998 Col. 1, p. 000005.

Braveman P, Kessel W, Egerter S, Richmond J. 1997. Early discharge and evidence-based practice: good science and good judgement. Joumal of American Medical Association, 278:334-336.

Bresser Pereira L.C. 1996. Da administração pública burocrática à gerencial. RSP 120:1 Brasilia: ENAP, jan/abr. 
Bresser Pereira LC. 1997. A Reforma do estado nos anos 90: lógica e mecanismos de controle. Brasil: Ministério da Administração Federal e Reforma do Estado, 58p. (Cadernos MARE da reforma do estado; c 1)

Bresser Pereira LC. 1998. Reforma do Estado para a cidadania: a reforma gerencial brasileira na perspectiva internacional. São Paulo: Ed. 34, 368p.

Bresser Pereira LC. 2000. A reforma gerencial do Estado de 1995. RAP $34(4): 7-26$.

Campos MM. 1961. Cinqüentenário da Faculdade de Medicina de Universidade Federal de Minas Gerais: notas, informaçōes e comentários. Belo Horizonte: $285 p$.

Campos et. al 1998. O setor público de saúde em Belo Horizonte: mudanças para a cidadania. In: Reis AT. et. al Sistema Único de Saúde em Belo Horizonte: reescrevendo o público. São Paulo: Xamã, p.325-335.

Campos FE, Albuquerque EM. 1999. As especificidades contemporâneas do trabalho no setor saúde: notas introdutórias para uma discussão. Revista de Economia Contemporânea, Rio de Janeiro: Instituto de Economia da UFRJ, 3(2):97-124.

Campos FCC. 2001. Gestão Intergovernamental e financiamento do Sistema Único de Saúde: apontamentos para os gestores municipais. In: Brasil. Ministério da Saúde. Gestão municipal de saúde: textos básicos. Tema 4, p.79-109.

Carapinheiro G. 1998. Saberes e poderes no hospital: uma sociologia dos serviços hospitalares. $3^{a}$ ed. Porto (Portugal): Edições Afrontamento. 296p.

Cecílio LCO. 1997. A modernização gerencial dos hospitais públicos: o difícil exercício da mudança. RAP 31(3):36-47.

Cecílio LCO. 1999. O Estado como prestador direto da assistência hospitalar: sim ou não? RAP 33(2):23-37.

Cherchiglia, M.L. 1999. Terceirização do trabalho nos serviços de saúde: alguns aspectos conceituais, legais e pragmáticos. In: Lima, JC \& Santana, JP (org) Especialização em Desenvolvimento de Recursos Humanos em Saúde: CADRHU. Natal: OPS/OMS. p. 367-385.

Cherchiglia ML, Dallari SG. 1999. A reforma do Estado e o setor público de saúde: governança e eficiência. RAP 33(5):65-84.

Cherchiglia ML, Girardi SN, Vieira RC, Marques RBA, Rocha PMW, Pereira LAC. 1998. Remuneración y produtividad: el caso de la Fundación Hospitalaria del Estado de Minas Gerais, Brasil, 1992-95, Pan American Joumal of Public Health, 4(2):112-120. 
Christensen T, Loegreid P. 2001. La nueva administración pública: el equilibrio entre la gobernanza y la autonomía administrativa. RSP 52(2):69-110.

CLAD/Centro Latino-americano de Administração para o Desenvolvimento. 1999. Uma nova gestão pública para a América Latina. RSP 50(1):123147.

Cochrane AL. 1985. Eficacia y eficiencia: reflexiones al azar sobre los servicios sanitarios. Barcelona: Salvat. 97p.

Cohn A. 1997. Notas sobre o estado, politicas públicas e saúde. In: Gerschman SE, Vianna MLW. A Miragem da Pós-Modemidade. democracia e politicas sociais no contexto da globalização. Rio de Janeiro: Fiocruz, p.101-113.

Cohn A. 1999. As politicas sociais no governo FHC. Tempo Social 11(2)183197.

Contandriopoulos AP. 1996. Reformar o sistema de saúde: uma utopia para sair de um status quo inaceitável. Saúde em Debate, Londrina: 49/50:53-64.

Cooper PJ. 1998. Crise de coordenação e governance no século 21. In: Sociedade e Estado: superando fronteiras. São Paulo: FUNDAP, p.178-79

Corbin J, Strauss A. 1998. Basics of qualitative research: techniques and procedures for developing grounded theory. $2^{a}$ ed. Thousand Oaks: Sage Publications

Costa NR, Melo MAC. 1998. Reforma do Estado e as mudanças organizacionais no setor saúde. Ciência \& Saúde Coletiva. 3(1):52-67.

Costa NR, Ribeiro JM, Silva PLB. 2000. Reforma do estado e mudanças organizacionais: um estudo de hospitais públicos. Ciência \& Saúde Coletiva. 5:427-442.

Costa NR. 1996. O banco Mundial e a política social nos anos $90-$ a agenda para a reforma do setor saúde no Brasil. In: Costa NR, Ribeiro JM (Org). Política de saúde e inovação institucional: uma agenda para os anos 90 . Rio de Janeiro: SDE/ENSP, p. 13-30.

Creswell JW. 1998. Qualitative Inquiry and research design: choosing among five traditions. Thousand Oaks: Sage Publications

Deephouse, DL. 1996. Does the isomorphsms legitimate? Academy of Management Joumal, 39:1024-1039.

Diniz E 1998. Uma perspectiva analitica para a reforma do Estado. Lua Nova 45:29-47. 
Diniz E. 1995. Governabilidade, Democracia e Reforma do Estado: os Desafios da Construção de uma Ordem Democrática no Brasil dos Anos 90. Dados. 38:385-415.

Diniz E. 1997. Crise, governabilidade e reforma do estado, In: Gerschman S, Werneck Vianna M.L (Org.) A miragem da pós-modemidade: democracia e politicas sociais no contexto da globalização. Rio de Janeiro: Fiocruz, p.115126.

Diniz E. 2000. Globalização, reformas econômicas e elites empresariais: Brasil anos 1990. Rio de Janeiro: FGV, 116p.

Dixon A, Robinson R. 2002. United Kingdom. In: Dixon e Mossialos (ed.) Health care systems in eight countries: trends and challenges. London: European Observatory on Health Care Systems. April, 114p

Duckett SJ. 1995. Hospital payment arrangement to encourage efficiency: the case of Victoria, Australia. Health Policy, 34:113-134.

Duff SQ, Farley DE. 1995. Patterns of decline among inpatient procedures. Public Health Rep., 110:674-697.

Ferlie E, Asburner L, Fitzgerald L, Pettigrew A. 1999. A nova administração pública em ação. Brasilia: UNB/ENAP, 468p.

Ferreira ABH. 1996. Novo dicionário Aurélio. $1^{\text {a }}$ ed. Rio de Janeiro: Nova Fronteira.

Figueiredo AC, Limongi F. 1995. Mudança Constitucional, Desempenho do Legislativo e Consolidação Institucional. Revista Brasileira de Ciências Sociais, 29:10.

Fonseca MA. 1995. Michel Foucault e a constituição do sujeito. São Paulo: EDUC: $158 \mathrm{p}$.

Foulcaut M. 1993. Microfísica do Poder. Rio de Janeiro: Ediçōes Graal 295p.

Gerschman S. 2001. Municipalização e inovação gerencial. Um balanço da década de 1990. Ciência \& Saúde Coletiva. 6:417-434

Girardi SN. 1998. A reforma regulatória do trabalho e das profissões de saúde: a política de recursos humanos que interessa para as reformas setorial e do Estado. IN: Brasil. Ministério da Saúde. Coordenação Geral de Desenvolvimento de Recursos Humanos para o SUS. Regulação e gestão de recursos humanos em saúde na perspectiva da reforma do Estado. $1^{\mathrm{a}}$ ed. Brasilia: Relatório Final.

Girardi SN. et. al 2001. Formas institucionais de terceirização de serviços de saúde e rede hospitalar filantrópica. Belo Horizonte: Relatório de Pesquisa $232 p$. 
Godoy SCB 2001. Absenteísmo - doença entre funcionários de um hospital universitário. Belo Horizonte; [Dissertação de Mestrado - Escola de Enfermagem da UFMG]

Goldenberg M. 1998. A arte de pesquisar: como fazer pesquisa qualitativa em Ciências Sociais, $2^{\mathrm{a}}$ ed, São Paulo: Record. 153p.

Goldstein AS. 1989. The Aspen: dictionary of health care administration, Rockville: Aspen Publishers. p. 84.

Goodin RE. 2000. Trusting individuals versus trusting institutional: generalizing the case of contract. Rationality and Society. 12(4):381-95.

Gouvêa CS, Travassos C, Fernandes C. 1997. Produção de serviços de saúde e qualidade da assistência hospitalar no Estado do Rio de Janeiro, Brasil - 1992 a 1995. Rev. Saúde Pública, 31:601-17.

Habermas J. 1996. Droit et démocratie: entre faits et normes. Paris: Gallimar.

Hanlon NT. 2001. Sense of place, organizational context and the strategic management of publicly funded hospitals. Health Policy, 58:151-173.

Hernandez JMC, Caldas MP. 2001. Resistência à mudança: uma revisão crítica. RAE 41(20:31-45.

Hirsch J 1996. Globalización, capital y Estado. México: Universidade Autónoma Metropolitana. 132p.

Hospital das Clínicas, 1992. I Seminário do Hospital das Clínicas. Belo Horizonte: 01 Setembro de 1992.

Hospital das Clínicas, 1998. III Seminánio do Hospital das Clínicas. Belo Horizonte: 01 Abril de 1998.

Houaiss A, Villar MS. 2001. Dicionário Houaiss da língua portuguesa Rio de Janeiro:Objetiva.

Ibañez N, Bittar OJNV, Sá ENC, Yamamoto EK, Almeida MF, Castro CGJ. 2001. Organizações sociais de saúde: o modelo do Estado de São Paulo. Ciência \& Saúde Coletiva 6(2):391-404.

Immergut EM. 1966. As regras do jogo: a lógica da política de saúde na França, na Suiça e na Suécia. RBCS n.30, p.139-65.

Jorge AO. et. al 1998. As internações Hospitalares em Belo Horizonte e o sistema municipal de controle e avaliação - algumas considerações. In: Reis AT. et al. Sistema Único de Saúde em Belo Horizonte: reescrevendo o público. São Paulo: Xamã, p.325-335. 
Kaufman RR, Segura-Ubiergo A. 2001. Globalização, Política Interna e Gasto Social na América Latina: Uma Análise de Corte Transversal com Série Temporal, 1973-1997 Dados, 44(3):

Kliksberg B. 1998. A gestão social. In: Sociedade e Estado: superando fronteiras. São Paulo: FUNDAP, p.83-90.

Krueger RA, Casey MA. 2000. Focus groups: a practical guide for applied research. $3^{\mathrm{a}}$ ed. Thousand Oaks: Sage Publications

Kurz R. 1998. O futuro é diferente: uma visão da sociedade no século 21. In: Sociedade e Estado: superando fronteiras. São Paulo: FUNDAP, p.15-34.

Kuttner R. 1998. Tudo à venda: as virtudes e os limites do mercado. São Paulo: Companhia das Letras, 494p.

Levcovitz E. 1997. Transição $x$ consolidação: o dilema estratégico do SUS. [Tese de Doutorado - Instituto de Medicina Social da UERJ]

Levcovitz E; Lima LD, Machado CV. 2001. Políticas de saúde nos anos 90 : realções intergovernamentais e o papel das Normas Operacionais Básicas. Ciência \& Saúde Coletiva, 6:269-291.

López-Casasnovas G, Saez M. 2000. The impact of teaching status on average costs in Spanish hospitals. Health Economics, 8(7):642-651.

Machado CV. 1999. Contextos, atores, instituições: um estudo exploratório a cerca das novas modalidades de gerência nos hospitais públicos do Rio de Janeiro nos anos 90. [Dissertação de Mestrado - Instituto de Medicina Social da UERJ].

Malik AM, Teles JP. 2001. Hospitais e programas de qualidade no Estado de São Paulo. RAE 41(3):51-59.

Marini Ferreira CM. 1995. Estratégia da Reforma do Aparelho de Estado. Seminários Friederich Naumann/IUPERJ, n. 1, p.1-20.

Martins L. 1998. Estado e sociedade: uma mudança de parâmetros, In: Sociedade e Estado: superando fronteiras. São Paulo: FUNDAP, p.35-44.

McGraw-Hill. 1988. The McGraw-Hill Essential Dictionary of Health Care, McGraw-Hill. 208-209

McKee M, Healey J. 2002. Hospitals in a changing Europe. London: European Observatory on Health Care Systems. United Kingdom, 295p.

Medici AC, Girardi SN. 1996. Produtividade e Força de Trabalho em Saúde: Uma Abordagem Pragmática para sua Mensuração. Belo Horizonte, [mimeo], 30p. 
Melo C, Tanaka O. 2001. As organizações sociais no setor saúde: inovando as formas de gestão? O\&S 8(22):107-119.

Mendes VLP. 2001. Inovação gerencial na administração pública, cidadania e direitos dos brasileiros. O\&S 8(22):119-135.

Meyer JW, Rowan B. 1999. Organizaciones institucionalizadas: la estructura formal como mito e ceremonia. In: Powell WW, DiMaggio PJ. (Org) El nuevo institucionalismo en el analisis organizacional. México: Fondo de Cultura Economica, p.79-103.

Mikkola H, Keskimäki I, Häkkinen U. 2001. DRG-related prices applied in a public health care sytem - can Finland learn from Norway and Sweden? Health Policy, 59:37-51.

Miller ME, Sulvetta MB, Englert E. 1995. Service mix in the hospital outpatient department: implications for Medicare payment reform. Health Serv Res. 30:58-78.

Mintzberg H. 1995. Criando organizações eficazes: estruturas em cinco configurações. São Paulo: Atlas, 304p.

Misoczky MC. 2001. Dilemas da burocracia no campo das politicas públicas: neutralidade, competição ou engajamento. O\&S 8(28):61-73.

Modesto P. 2000. Notas para um debate sobre o princípio da eficiência. RSP 51(2):107-121.

Nogueira RP, Girardi SN. 1997. A Reforma do Estado e os Recursos Humanos de Saúde: flexibilidade de ação e continuidade de direção. Brasilia, s/d, 6p. [Mimeografado]

Nogueira RP. 1999. Reforma do estado, o SUS em reforma e os recursos humanos. In: Lima, JC \& Santana, JP (Org) Especialização em Desenvolvimento de Recursos Humanos em Saúde: CADRHU Natal:OPS/OMS. p. 65-81.

Novik M. 1996. La crisis como oportunidad. Elementos para enterpretar los cambios en la gestión de personal de salud. In: Quintana PB; Campos FE; Novik M. (Org) Gestion de recursos humanos en las reformas sectoriales en salud: cambios y oportunidades. Organización Panamericana de la Salud. Washington: p. 23-52. 1996.

Osborne D, Gaebler T. 1995. Reinventando o Governo: Como o Espírito Empreendedor Está Transformando o Setor Público. Brasília, $\mathrm{MH}$ Comunicação.

Palmer S, Torgerson DJ. 1999. Economics notes: Definitions of efficiency BMJ 318:1136-36. 
Perrow C. 1972. Complex Organizations: a critical essay. New York: McGraw Hill.

Perrow C. 1992. Economic theories of organization. In: Zukin S, DiMaggio P. Strucutures of capital: the social organization of the economy. Cambridge University Press. p.121-152.

Pierantoni CR. 2000 Reformas da Saúde e recursos humanos. Rio de Janeiro [Tese de Doutorado - Instituto de Medicina Social da UERJ]

Pierantoni CR. 2001. As reformas do Estado, da saúde e recursos humanos: limites e possibilidades. Ciência \& Saúde Coletiva. 6:341-360.

Piore M, Sabel C. 1984. The Second industrial divide. New York: Basic Books.

Pollit C. 1994. Managerialism and the Public Services. Oxford, Blackwell.

Pontes MC. 1995. Agency theory: a framework for analyzing physician services. Health Care Manage Rev. 20: 57-67.

Potter SJ. 2000. Can efficiency and community service be symbiotic?: a longitudinal analysis of non-for-profit and for-profit hospitals in the United States. New York: Garland Publishing, 160 p.

Powell WW, DiMaggio PJ. 1999. Retorno a la jaula de hierro: el isomorfismo institucional y la racionalidad colectiva en los campos organizacionales. In: Powell WW, DiMaggio PJ. (Org) El nuevo institucionalismo en el analisis organizacional. México: Fondo de Cultura Economica, p.104-125.

Przeworskl A. 1996. Reforma do Estado: responsabilidade política e intervenção econômica. RBCS 32:18-40.

Przeworski A. 1998. Sobre o desenho do Estado: uma perspectiva agent $x$ principal. In: Bresser Pereira LC, Spink PK. (Org) Rio de Janeiro: FGV, 3973.

Puig-Junoy J. 1999. Managing risk selection incentives in health sector reforms. The International Journal of health Planning and Management, 14:287-311.

Quintana PB, Campos F, Novik M. (Org) 1996. Gestión de recursos humanos en las reformas sectoriales en salud: cambios y oportunidades. Organización Panamericana de la Salud. Washington: p.23-52.

Revista da Fundação SESP. 1982. 27(2):116

Roggenkamp SD, White KR. 2001. Is hospital case management a rationalized myth? Social Science \& Medicine, 53:1057-66. 
Rossetti JP. 1997. Introdução à economia $17^{\mathrm{a}}$ ed. São Paulo: Atlas.

Salles AA. 2000. Estado democrático de direito e a reforma administrativa. [Dissertação de Mestrado - Faculdade de Direito da UFMG].

Santana JP. 1999. A gestão do trabalho nos estabelecimentos de saúde: elementos para uma proposta. In: Lima JC, Santana JP. (Org) Especialização em Desenvolvimento de Recursos Humanos em Saúde: CADRHU Natal:OPS/OMS. P. 387-400.

Santos Boaventura S. 1999. Pela mão de Alice: o social e o politico na pósmodernidade. $5^{\text {a }}$ ed. São Paulo: Cortez, 348p.

Santos M. 2001. Por uma outra globalização: do pensamento único à consciência universal. $7^{\circ}$ ed. Rio de Janeiro: Record, 174p.

Schiffman L, Kanuk L. 1991. Consumer behavior. $4^{\text {a }}$ ed. New Jersey: Prentice-Hall.

Scott WR.1987. The adolescence of institutional theory. Administrative Science Quarterly ,32:493 -511.

Silva LM, Formigli VLA. 1994. Avaliação em saúde: limites e perspectivas. Cad. Saúde Públ. Rio de Janeiro, 10(1):80-91.

Suárez AB. 2000. Reflexiones acerca del uso de los conceptos de eficiencia, eficacia y efetividada en el sector salud. Rev. Cubana Salud Publica 26(1):50-56.

Suchman MC. 1995. Managing legitimacy: strategic and institutional aproches. Academy of Management Review, 20:571-610.

Suwandono A, Gani A, Purwani S; Blas E, Brugha R. 2001. Cost recovery beds in public hospitals in Indonesia. Health Policy Plan, 16:10-18.

Ugá MLD. 1997. Ajuste estrutural, governabilidade e democracia, In: Gerschman S, Werneck Vianna ML (Org.) A miragem da pós-modemidade: democracia e politicas sociais no contexto da globalizaçấo. Rio de janeiro: Fiocruz, p.81-99.

Vaitsman J. 2001. Gerencialismo, cultura e expectativas entre servidores públicos de saúde. RAP 33(1):29-37.

Vieira MPA, Peixoto MRC; Khoury YMA. 1991. A pesquisa em história $2^{\mathrm{a}}$ ed. São Paulo: Ática. 80p.

World Bank 1992. Govemance and Development. Washington: World Bank.

World Bank 1994. Governance: the World Bank experience. Washington: World Bank. 
Zucchi P, Bittar OJNV, Haddad N. 1998. Produtividade em hospitais de ensino no Estado de São Paulo, Brasil. Rev. Panam Salud Publica, 4:311316.

Zucker LG. 1999. El papel de la institucionalización en la persistencia cultural. Powell WW, DiMaggio PJ. (Org) El nuevo institucionalismo en el analisis organizacional. México: Fondo de Cultura Economica, p.126-153.

Zucker LG.1987. Institutional theories of organization. Annual Review of Sociology ,13:443- 464 .

Zwanziger J, Melnick GA, Simonson L. 1996. Differentiation and specialization in the California hospital industry, 1983 to 1988. Medical Care; 34:361-372. 


\section{ANEXO 1}

ROTEIRO PARA ENTREVISTA COM DIRETORES E CHEFIAS INTERMEDIÁRIAS

1. O que você já ouviu falar sobre a Reforma do Estado?

2. Qual seria o motivo da reforma do Estado? E especificamente para o setor saúde?

3. Quais as alterações que ela trouxe para: sua vida pessoal e profissional? (Explicação sobre a Reforma do Estado se não souberem) A reforma do Estado brasileiro dos anos 90: o ajuste fiscal (reforma tributária); reformas econômicas orientadas para o mercado (privatização); a reforma da previdência social (aposentadoria por tempo de contribuição, fim das aposentadorias especiais, limite de idade para se aposentar, não acumulação aposentadoria com outros vencimentos públicos); a inovação das organizativas na prestação de serviços sociais (organizações sociais, autonomia universitária); e (v) a reforma do Aparelho do Estado (reforma da administração pública - fim da obrigatoriedade do RJU, flexibilização da estabilidade, limitação de vencimentos).

4. Quais aspectos da Reforma do Estado afetaram mais diretamente o setor saúde?

5. Essa (s) reforma (s) trouxeram alguma alteração para o Hospital das Clínicas: na forma de organização, na gerência; nas relações e processo de trabalho e para a população atendida por ele, a partir de 1994 ?

6. Houve alguma resistência a essas mudanças (greve, aumento do absenteismo, boicote)?

7. Ocorreram mudanças na relação entre o Hospital das Clínicas e (Governo federal, estadual, municipal; reitoria; setor privado; unidades acadêmicas)? 
8. A Reforma do Estado coloca a eficiência como um dos seus conceitos chave. O que é eficiência para você ?

9. A que você relaciona a idéia de eficiência?

10. O Plano Diretor da Reforma do Aparelho de Estado define eficiência na administração pública como "a necessidade de reduzir custos e aumentar a qualidade dos serviços, tendo o cidadão como beneficiário". Faça um comentário sobre esta definição.

11. Como gestor como você se coloca diante desta definição?

12. Você considera o Hospital das Clínicas eficiente? Em que?

13. Você pensa que o Hospital das Clínicas é mais eficiente hoje do que a seis anos atrás? No que ele é mais eficiente?

14. Seu setor de trabalho é eficiente? No que ele é eficiente e no que ele não é?

15. Quais são os entraves para que o HC seja um hospital eficiente?

16. Quais seriam as soluções?

17. Uma organização pública de saúde pode ser eficiente? Como?

18. Um hospital público pode ser eficiente e continuar público?

19. Você pensa que é importante para um hospital público ser eficiente? Por que?

20. Em que setores um hospital público deve ser eficiente e em quais não deve?

21. Um hospital público pode ser eficiente e ter qualidade?

22. Em que medida a eficiência se relaciona com:

Qualidade

Cidadania

Ser uma instituição pública

Responsabilização 


\section{ANEXO 2}

\section{ROTEIRO PARA OS GRUPOS FOCAIS}

1. Por favor, diga o seu nome, a quanto tempo trabalha no Hospital das Clínicas e em qual setor você trabalha

2. O que você já ouviu falar sobre a reforma da previdência, da administração pública, da autonomia da Universidade e dos hospitais universitários?

(Explicação sobre a Reforma do Estado se não souberem) A reforma do Estado brasileiro dos anos 90: o ajuste fiscal (reforma tributária); reformas econômicas orientadas para o mercado (privatização); a reforma da previdência social (aposentadoria por tempo de contribuição, fim das aposentadorias especiais, limite de idade para se aposentar, não acumulação aposentadoria com outros vencimentos públicos); a inovação das organizativas na prestação de serviços sociais (organizações sociais, autonomia universitária); e (v) a reforma do Aparelho do Estado (reforma da administração pública - fim da obrigatoriedade do RJU, flexibilização da estabilidade, limitação de vencimentos).

3. Como estas reformas afetam sua vida pessoal, profissional?

4. Essa (s) reforma (s) trouxeram alguma alteração para o Hospital das Clínicas: na forma de organização, na gerência; nas relações e processo de trabalho, com o sindicato e para a população atendida por ele, a partir de 1994 ?

5. Houve alguma resistência a essas mudanças (greve, aumento do absenteísmo, boicote)?

A reforma tem como conceito-chave a eficiência. 
6. Qual é a primeira coisa que lhe vem a mente quando você escuta a palavra eficiência?

7. Você pensa que o Hospital das Clínicas e o seu setor de trabalho funcionam de acordo com sua idéia de eficiência?

8. O que você diz para os outros sobre a eficiência do $\mathrm{HC}$.

9. No que o HC é eficiente e no que ele não é?

10. No que seu setor de trabalho é mais e menos eficiente?

11. Como um hospital público pode ser eficiente e continuar público?

12. Um hospital público pode ser eficiente e ter qualidade?

13. Qual a importância de uma administração eficiente em um hospital público?

14. Quais são as dificuldades encontradas para que o HC seja eficiente? Qual é a mais importante?

15. Feche os olhos e imaginem que estão em uma longa viagem em uma terra distante. Ao longo do caminho vocês encontraram uma caixa especial que tem dentro dela soluçōes para os problemas e dificuldades para o HC ser um hospital mais eficiente. Quando você abre a caixa você encontra a resposta para o problema. Qual resposta você encontrou? 


\section{ANEXO 3}

\section{TERMO DE CONSENTIMENTO LIVRE E ESCLARECIDO}

Eu,

aceito

livremente participar como entrevistado na Pesquisa "O conceito de eficiência na reforma setorial do Estado brasileiro nos anos 90: difusão e apreensão em um hospital público" sob responsabilidade da Professora Mariangela Leal Cherchiglia, cujo objetivo é conhecer como os trabalhadores de saúde entendem a idéia de eficiência. Como a percebem na organização do Hospital das Clínicas, no seu ambiente de trabalho, nas relações entre chefia e funcionários e entre os funcionários e se identificam resistências às mudanças organizacionais implantadas a partir de 1990. O resultado desta investigação pretende ser instrumento de auxílio na melhoria da qualidade do trabalho dia-a-dia desta Instituição, bem como do serviço prestado à população. Estou ciente de que as entrevistas serão gravadas e que tão logo sejam transcritas serão apagadas garantindo assim sua confidencialidade, minha privacidade e anonimato não correndo riscos de que minhas opiniões e idéias possam ser utilizadas contra mim. Estou ciente, também de que posso recusar a participar ou retirar-me sem necessidade de qualquer consentimento em qualquer fase da pesquisa sem que isso traga-me nenhuma penalização. Estou, ainda, ciente que os resultados da pesquisa serão apresentados em Seminário no Hospital das Clínicas e divulgados em artigos científicos e Congressos aos quais terei livre acesso. Também, estou ciente que se tiver qualquer reclamação contra a pesquisadora posso procurar o Comitê de Ética em Pesquisa do Hospital das Clínicas/UFMG no endereço abaixo.

Após convenientemente esclarecido pela pesquidadora e ter entendido o que me foi explicado consinto em participar do projeto de pesquisa acima.

Belo Horizonte, de de 2001

Assinatura do Entrevistado

\section{Comitê de Ética em Pesquisa:}

Avenida Alfredo Balena, 100, $1^{\circ}$ andar, ala sul

Telefone: 32489364
Assinatura da Pesquisadora

\author{
Pesquisadora: \\ Mariangela Leal Cherchiglia \\ Departamento de Medicina Preventiva e Social \\ Avenida Alfredo Balena $190,9^{\circ}$ andar, sala \\ 9001 \\ Telefone:3 2489941 \\ E-mail: cherchml@medicina.ufmg.br
}




\section{ANEXO 4}

TABELA 32 - Assuntos Discutidos e Decisões Tomadas pelo Conselho Administrativo do Hospital das Clínicas/UFMG em 1994

\begin{tabular}{|l|}
\hline \multicolumn{2}{|c|}{ Assuntos discutidos } \\
\hline $\begin{array}{l}\text { Organização e reestruturação: proposta de novo regimento -, incluindo a } \\
\text { discussão sobre o papel do Conselho Administrativo e sua forma de atuação, } \\
\text { criação e extinção de serviços }\end{array}$
\end{tabular}

Gestão: o processo de indicação, eleição e posse da nova diretoria. Pagamento de gratificação chefias informais.

Financiamento: MEC não repassa mais a folha de pagamento do pessoal da FUNDEP, existe a possibilidade da admissão de funcionários para o quadro permanente; contrato com plano privado de saúde

Relaçōes Institucionais: solicitação ao MEC para aproveitamento dos quadros existentes no ex-INAMPS para os Hospitais Universitários

Relações de trabalho greves, reivindicações por melhoria de trabalho, pagamento de gratificações, etc)

\section{Decisōes Tomadas}

06 de abril

Aprovação de alteração do Art 10 do Regulamento do Hospital 1) As reuniōes do C.A do HC/UFMG se realizarão em primeira convocação, com a presença da maioria de seus membros e as decisões serão tomadas por maioria simples dos membros presentes ou em Segunda convocação, caso não tenha atingido o quorum, quinze minutos após, com um terço de seus membros ou em terceira convocação, trinta minutos após, com um quinto de seus membros, com decisões tomadas por maioria dos presentes.

Cláusula Única: A partir da Segunda convocação, as deliberações serão em função dos assuntos pautados, apenas.

2)Após um ano de vigência dessa proposição, deverá ser reavaliada sua pertinência.

3) Os membros com ausência não justificada por três vezes, perderam o mandato, sendo sua representação comunicada para providência de substituição. (Resolução 1/94)

15 de junho

Concessão de uma sala para os funcionários em greve da FUNDP e ao transito dentro da Instituição, por solicitação do Reitor, após ter sido negada pelo Diretor

Permanência de membros aposentados como membros do corpo clínico do HC (Resoluções 06 e 07/94)

Discutidas as medidas a serem tomadas durante a greve dos servidores técnicosadministrativos do HC (Resolução 03/94) 
TABELA 32 - Assuntos Discutidos e Decisões Tomadas pelo Conselho Administrativo do Hospital das Clínicas/UFMG em 1994 (Continuação)

\begin{tabular}{|l|}
\hline \multicolumn{1}{|c|}{ Decisões Tomadas } \\
\hline 22 de junho \\
Posse da nova diretoria biênio 94/96 \\
\hline 06 de julho \\
Definiu-se que as reuniões do CA passarão a ocorrer a partir desta data, uma vez \\
por mês sistematicamente às primeiras Quartas-feiras \\
\hline 04 de agosto \\
Foram criadas quatro comissões: permanentes de trabalho do CA: Comissão de \\
Legislação e de convênio (Resolução 14/94) \\
Comissão de Desenvolvimento dos serviços especiais de diagnóstico e tratamento \\
(Resolução 15/94), \\
Aprovado o parecer da comissão que estuda as propostas para elaboração de \\
novas politicas para o perfil da clientela a ser atendida por este hospital. "os \\
parâmetros para a determinação da ocupação dos leitos hospitalares existentes \\
deverão estar contidos naqueles do convênio HC/SUS. A clientela do SUS será \\
destinado o mínimo de 70\% dos leitos hospitalares e que havendo ampliação da \\
quantidade de leitos do hospital, poderá ser destinado então, até 30\% dos leitos \\
para convênios e particulares (Resolução 10/94) \\
\hline 05 de outubro \\
Posse as comissões permanentes e especiais \\
\hline 16 de novembro \\
Aprovação em condição provisória a criação do Serviço de Infecção Hospitalar do \\
HC/UFMG (CCIH-UFMG), através da portaria 02/94 de 28 de outubro de 1994. \\
Suspensão da implementação da criação da comissão Permanente de curadores, e \\
da Comissão Especial de interrelação mercadológica e relaçōes públicas entre o \\
HC e a sociedade. \\
E aprovado o contrato de prestação de serviços entre CASSI/UFMG através do HC \\
\hline 14 de dezembro \\
Portaria 03/94 cria uma comissão especial para coordenar o processo de \\
elaboração de anteprojeto de regimento do HC
\end{tabular}

Fonte: Atas do Conselho Administrativo do HC/UFMG 
TABELA 33 - Assuntos Discutidos e Decisões Tomadas pelo Conselho Administrativo do Hospital das Clínicas/UFMG em 1995

\section{Assuntos discutidos}

As primeiras reuniões do CA no ano de 1995 procuram debelar a crise da demissão dos funcionários da FUNDEP (500 funcionários) e sua substituição pelos novos concursados dentro do RJU. Depois a pauta é tomada pela discussão de uma proposta de transformação dos hospitais universitários em organizações sociais.

Outra grande polêmica, ainda neste ano foi o Decreto no. 1590 de 12 de setembro de 1995, que obrigava ao cumprimento da jornada de 40 horas semanais na administração pública federal, salvo as exceçōes. Como diversas categorias profissionais faziam 30 horas (acordo interno do $\mathrm{HC}$ ) houve muita discussão e resistências. O último bimestre do ano é tomado pela crise institucional que culminou com o pedido de demissão da diretoria e a indicação de um diretor "protempore ${ }^{n}$. Entre uma crise e outra se discutia o regulamento.

\section{Decisões Tomadas}

03 de maio

Aprovação do documento "Manifestação do Conselho Administrativo do HC/UFMG sobre a política para os Hospitais Universitários" cujos principais pontos são:

a) projeto dos HU deve ser confrontado ao projeto de estado brasileiro através de reafirmação de projeto social no qual a instancia federal não pode se excluir em detrimento de seus deveres para com a sociedade;

b) HU tem como objetivos indissociáveis assistência, ensino, pesquisa, o que o diferencia dos demais serviços de saúde;

c) HU deve prestar serviços em todos os niveis, do primário ao quaternário, prevenção, cura ou reabilitação, devendo desenvolver e incorporar tecnologias;

d) a questão de fundo das discussões sobre os HU é politica considerando: 1) política de implantação do SUS; 2) valorização e financiamento dos setores de educação e saúde; 3 ) as respostas que devem ser dadas às demandas sociais.

e) HU parte indissociável da universidade, relações formais com os órgãos de deliberação superior $e$ as unidades acadêmicas da área de saúde;

f) as universidades devem assumir suas responsabilidades junto aos $\mathrm{HU}$, apoio politica, jurídico e administrativo, reconhecendo as atividades ali desenvolvidas como universitárias.

g) devem ser instituídos mecanismos urgentes para superação de entraves gerenciais administrativos e financeiros;

h) $\mathrm{RH}$, a manifestação é pela manutenção do RJU, introduzindo normas de flexibilização que permitam melhorar a dinâmica de gerencia de pessoal, e que o acesso seja público; devem ser aprimorados mecanismos de gestão de RH que valorizem avaliação, educação permanente e progressão funcional; em caráter complementar podem ser admitidas formas alternativas de contratação de pessoal para garantir as atividades do hospital. 
TABELA 33 - Assuntos Discutidos e Decisões Tomadas pelo Conselho Administrativo do Hospital das Clínicas/UFMG em 1995 (Continuação)

\begin{tabular}{|l|}
\hline \multicolumn{1}{|c|}{ Decisões Tomadas } \\
\hline 21 de junho \\
Aprovado por unanimidade o parecer sobre o convenio UNIMED \\
\hline 20 de setembro \\
Convite para que o Procurador da universidade participe da próxima reunião para \\
esclarecimento sobre os aspectos jurídicos envolvidos no problema das 6 horas \\
\hline 27 de setembro \\
Aprovado o cumprimento do decreto 1590, de 10.08.95, sobre a jornada de trabalho \\
dos servidores lotados no HC \\
\hline 08 de novembro \\
Aprovada a marcação de uma reunião de uma comissão do CA com o reitor para \\
discussão da situação financeira do hospital. \\
\hline 22 de novembro \\
Aprovada a proposta de voto de confiança ao diretor para prosseguimento do \\
projeto gerencial enquanto os membros do conselho o analisariam e \\
encaminhariam propostas para discussão no CA. \\
Aprovada a comissão de defesa do HC, que deverá tomar providencias necessárias \\
para a realização de reuniōes com as autoridades competentes com o objetivo de \\
conscientizar os órgãos públicos da área de saúde sobre a situação do HC. \\
\hline 06 de dezembro \\
Aprovado que a substituição do diretor seja feita pelo decano. Assumirá a direção \\
do HC como pró tempore, o quarto decano, em função da recusa dos anteriores, \\
Prof. Cláudio de Souza
\end{tabular}

Fonte: Atas do Conselho Administrativo do HC/UFMG 
TABELA 34 - Assuntos Discutidos e Decisões Tomadas pelo Conselho Administrativo do Hospital das Clínicas/UFMG em 1996

\section{Assuntos Discutidos}

Retomada a discussão sobre o cumprimento do Decreto 1590 de setembro de 1995. A proposta de novo regulamento do HC é amplamente discutida e bem como - Plano Diretor do biênio. Discutido o convênio do a Secretaria Municipal de saúde de Belo Horizonte para a criação do Pronto Atendimento Clínico no HC. E greve dos funcionários

\section{Decisões Tomadas}

16 de janeiro

Assume como diretor do HC o Prof. Juarez de Oliveira Castro. Para o cargo de vice-diretor, em função da recusa dos decanos e composta lista tríplice para encaminhando ao reitor, tendo o Prof. Walter Antonio Pereira aceitado o cargo.

07 de fevereiro

Composta comissão que deverá apresentar no prazo de 30 dias proposta de implementação do Decreto $1590 / 95$, considerando as categorias funcionais e locais de trabalho dos servidores.

Aprovada a autorização para que a diretoria elabore minuta de convenio com a Secretaria Municipal de Saúde, a ser submetida ao CA

14 de fevereiro

Plenário recomenda à Comissão de Regimento que elabore minuta com as discussões havidas e encaminhe ao CA para discussão.

17 de abril

Aprovado convênio com a SMS/BH para a criação do Pronto Atendimento clínico no $\mathrm{HC}$

04 de setembro

Aprovação do organograma do $\mathrm{HC}$ contido no anteprojeto de regimento versão $2^{\circ}$ semestre de 1996

18 de setembro

Aprovada a criação da diretoria de ensino, pesquisa e extensão.

11 de dezembro

Aprovada a criação das divisões de Apoio Terapêutico e Propedêutico, Saúde Mental, Material, Ensino e Pesquisa.

Delegada ao diretor do $\mathrm{HC}$ a proposição de convênios até $30 \%$ de ocupação dos leitos hospitalares. Criada comissão para assessoria ao diretor nessas questões

Fonte: Atas do Conselho Administrativo do HC/UFMG 
TABELA 35- Assuntos Discutidos e Decisões Tomadas pelo Conselho Administrativo do Hospital das Clinicas/UFMG de 1997

\section{Assuntos Discutidos}

Todo o ano de 1997 foi tomado por discussões de formas de enfrentamento da crise financeira do $\mathrm{HC}$ que resultou em fechamento de leitos e demissão de pessoal e interrupção dos estágios do curso de medicina. São buscados apoio na reitoria, secretaria municipal e estadual de saúde, MEC, sociedade civil, empresas etc. No segundo semestre, com a retomada das atividades do $\mathrm{HC}$, os assuntos discutidos voltam a ser sobre a reorganização (regimento aliado à criação de nova diretoria $e$ divisōes), as relações de trabalho (regime de trabalho de 30 horas e pagamento de gratificações) e volta em pauta a discussão das organizaçōes sociais e da autonomia universitária. É discutido a necessidade de otimização da capacidade instalada do HC bem como dos processos administrativos (faturamento)

\section{Decisões Tomadas}

02 de maio

Constituição do Comitê de Mobilização para sensibilização da sociedade quanto a gravidade da crise do $\mathrm{HC}$

09 de julho

Proposta de reestruturação do $\mathrm{HC}$, utilizando somente os servidores pagos pelo MEC aprovada pelo Conselho Universitário e reitoria.

06 de agosto

Retomada das atividades pelo $\mathrm{HC}$

Aprovação da criação da Divisão de enfermagem

20 de agosto

Extinção do Conselho Técnico Científico e criação da Diretoria de Ensino, Pesquisa e Extensão

17 de setembro

Aprovação de 30 convênios com planos de saúde (com posição contrária do Diretório acadêmico dos Estudantes da medicina - DAAB)

01 de outubro

Aprovada Comissão organizadora do III Seminário do HC

19 de novembro

Aprovada estrutura da Diretoria de Ensino, Pesquisa e Extensão

10 de dezembro

Aprovada, em tese, a instituição de uma fundação de apoio ao HU - FAHU-UFMG, através de resolução que contém o procedimento que deve ser encaminha-la à reitoria para análise do ponto de vista politica e administrativo, solicitando manifestação formal Estabelece o prazo de 120 dias para proceder à deliberação sobre a proposta definitiva do estatuto da FAHU-UFMG

Fonte: Atas do Conselho Administrativo do HC/UFMG 
TABELA 36 - Assuntos Discutidos e Decisões Tomadas pelo Conselho Administrativo do Hospital das Clínicas/UFMG em 1998

\section{Assuntos Discutidos}

Discussão sobre a paridade de voto entre professores, alunos e funcionários na eleição de diretor do hospital e das possiveis pressões da reitoria para a não recondução da diretoria atual, Relações de trabalho (greve funcionários universidade, forma de pagamento para professores, gratificação docentes Serviços Profissionais). Mudança de diretoria e discussão sobre o regimento (a vigência de dois organagramas tem trazido dificuldades, como no ano anterior, na organização dos serviços. Surge, até mesmo, conflitos de poder entre a velha e a nova estrutura). Discussão sobre os acertos com a SMS/BH para a assinatura de convênio global e posicionamento do HC na estrutura da UFMG (Unidade especial)

Decisões Tomadas

20 de maio

Aprovado o Conselho de Usuários

26 de maio

Aprovada resolução que define a proporcionalidade dos votos segundo os segmentos: $50 \%$ para docentes e $50 \%$ para funcionários e corpo discentes

22 de junho

Acordo entre o movimento grevista e direção do hospital de se paralisar $50 \%$ das atividades do $\mathrm{HC}$

25 de junho

Apresentação do resultado da consulta à comunidade para a escolha da nova diretoria e Organização da lista triplice encaminhada à reitoria.

01 de julho

Aprovada a elaboração de documento do CA apoiando a residência médica, destacando sua importância para o $\mathrm{HC}$, para ser entregue à comissão do MEC

12 de agosto

Apresentação da proposta de gestão da nova diretoria

Definida nova comișsão para elaboração de ante-projeto de regimento

(última ata do Conselho Administrativo de 1998 encontrada, foi a de 30 de setembro)

Fonte: Atas do Conselho Administrativo do HC/UFMG 
TABELA 37 - Assuntos Discutidos e Decisões Tomadas pelo Conselho Administrativo do Hospital das Clínicas/UFMG em 1999

\section{Assuntos Discutidos}

Discussão sobre situação financeira do HC (que fechou 1998 sem déficit), questiona-se a postura do MEC de desfinanciamento, transferindo para os hospitais universitários a responsabilidade de se custearem (através, principalmente de serviços para o SUS). Apresentado e discutido a proposta de "Reorganização gerencial do Hospital das Clinicas - Diretrizes Gerais", elaborado pela diretoria. Discussão sobre o regimento e convênio Global com a SMS/BH. Apresentação de contas biênio $96-98$.

\section{Decisões Tomadas}

03 de fevereiro

Definida a data de 30.04 .99 para apresentação do relatório final da Comissão de Regimento.

17 de março

Aprovada a implantação do modelo gerencial Unidades Funcionais, que deverá ser acompanhada pela Comissão de Implantação e um relatório do processo deverá ser apresentado ao CA a cada duas reuniōes do mesmo

10 de dezembro

Falta de quorum para aprovação do regimento

Fonte: Atas do Conselho Administrativo do HC/UFMG 
TABELA 38 - Assuntos Discutidos e Decisões Tomadas pelo Conselho Administrativo do Hospital das Clínicas/UFMG de 2000

\section{Assuntos discutidos}

Aprovado (pelo menos em grande parte) o novo regimento. Discutidas relações de trabalho (greve, gratificaçōes e jornada de trabalho) Relatadas as dificuldades das relaçōes com o SUS/BH e MG "os procedimentos/internaçōes que têm melhor rentabilidade são normalmente oferecidas à iniciativa privada e as que dão prejuízo à iniciativa privada são impostas ao setor público. Lembrou que as relações com o SUS, apesar de ter dobrado o faturamento deve também ter dobrado o custo, pois - Hospital está absorvendo os procedimentos de alto custo do SUS" o que seria uma das causa das dificuldades financeiras enfrentadas pelo $\mathrm{HC}$. Eleição nova diretoria. Discutida parceria com outras unidades acadêmicas e setor público.

\section{Decisões Tomadas}

01 de março

Aprovação de vários itens do regimento (que deverá voltar a aprovação final)

19 de abril

.Aprovada a criação, através da Escola de Enfermagem com apoio do $\mathrm{HC}$, dos cursos de auxiliar de enfermagem e técnico de enfermagem, o primeiro com recurso do FAT e o segundo a ser ofertado sem ônus a pessoal do HC que não tenha qualificação. Aprovado convênio com a Faculdade de Diamantina para estágio supervisionado do Curso de Enfermagem, utilizando inclusive os ambulatórios, sem prejuizo dos estágios realizados por alunos da UFMG

30 de maio

Aprovado o texto de apoio do Conselho Administrativo ao movimento grevista (funcionários técnico-administrativos da universidade)

14 de junho

Reunião extraordinária, como item de pauta a Eleição para a direção do Hospital das Clinicas: apresentação do resultado da consulta à comunidade, organização da lista triplice e conclusão do processo eleitoral.

23 de agosto

Aprovado convênio com a FHEMIG, para lavagem de roupa

13 de setembro

Aprovada a criação de Comissão com o objetivo de apresentar uma proposta de resolução para prestação de serviços no $\mathrm{HC}$, de acordo com a resolução 10/95 do Conselho Universitário.

Fonte: Atas do Conselho Administrativo do HC/UFMG 